\title{
Hydrodynamic Pathways in a Mature Constructed Wetland
}

\author{
by
}

\author{
Sean Speer \\ B.Eng. (Environmental)
}

A Thesis Submitted to the School of Graduate Studies in Partial Fulfillment of the Requirements for the Degree of

\section{Masters of Applied Science \\ Environmental Engineering}

in the
Ottawa Carleton Institute of Environmental Engineering Department of Civil and Environmental Engineering Carleton University Ottawa, Canada




$\begin{array}{ll}\begin{array}{l}\text { Library and } \\ \text { Archives Canada }\end{array} & \begin{array}{l}\text { Bibliothèque et } \\ \text { Archives Canada }\end{array} \\ \begin{array}{l}\text { Published Heritage } \\ \text { Branch }\end{array} & \begin{array}{l}\text { Direction du } \\ \text { Patrimoine de l'édition }\end{array} \\ \begin{array}{l}\text { 395 Wellington Street } \\ \text { Ottawa ONK1A ON4 } \\ \text { Canada }\end{array} & \begin{array}{l}\text { 395, rue Wellington } \\ \text { Ottawa ON K1A ON4 } \\ \text { Canada }\end{array}\end{array}$

\author{
Your file Votre référence \\ ISBN: \\ Our file Notre reterence \\ ISBN:
}

NOTICE:

The author has granted a nonexclusive license allowing Library and Archives Canada to reproduce, publish, archive, preserve, conserve, communicate to the public by telecommunication or on the Internet, loan, distribute and sell theses worldwide, for commercial or noncommercial purposes, in microform, paper, electronic and/or any other formats.

The author retains copyright ownership and moral rights in this thesis. Neither the thesis nor substantial extracts from it may be printed or otherwise reproduced without the author's permission.
AVIS:

L'auteur a accordé une licence non exclusive permettant à la Bibliothèque et Archives Canada de reproduire, publier, archiver, sauvegarder, conserver, transmettre au public par télécommunication ou par l'Internet, prêter, distribuer et vendre des thèses partout dans le monde, à des fins commerciales ou autres, sur support microforme, papier, électronique et/ou autres formats.

L'auteur conserve la propriété du droit d'auteur et des droits moraux qui protège cette thèse. Ni la thèse ni des extraits substantiels de celle-ci ne doivent être imprimés ou autrement reproduits sans son autorisation.
In compliance with the Canadian

Privacy Act some supporting forms may have been removed from this thesis.

While these forms may be included in the document page count, their removal does not represent any loss of content from the thesis.
Conformément à la loi canadienne sur la protection de la vie privée, quelques formulaires secondaires ont été enlevés de cette thèse.

Bien que ces formulaires aient inclus dans la pagination, il n'y aura aucun contenu manquant.

\section{Canadä}


The undersigned hereby recommend to

the Faculty of Graduate Studies and Research

acceptance of the thesis

\title{
Hydrodynamic Pathways in a Mature Constructed Wetland
}

\author{
Submitted by \\ Sean Speer, B.Eng. \\ in partial fulfillment of the requirements \\ for the degree of Masters of Applied Science
}

Prof. A.O. Abd El Halim

Chair. Department of Civil and Environmental Engineertug

Prof. P. Champagne

Thesis Supervisor

Carleton University 


\begin{abstract}
One of the low-cost options for the treatment of agricultural wastewaters is the use of constructed wetlands. In order to better understand the physical mechanism at work within a mature constructed wetland, a study was conducted at the Dignard Wetland in Ontario, Canada. Throughout the course of a two-year study, percent removals of $\mathrm{BOD}_{5}$ $(45 \%)$, ammonia $(56 \%)$, nitrates $(8 \%)$, phosphorous $(33 \%)$, and TKN $(67 \%)$ were monitored. The movement of a tracer was also monitored through the two marsh cells of the constructed wetland. The kinetic rate constants were calculated as $5.7 \mathrm{~m} / \mathrm{y}$ for $\mathrm{BOD}_{5}$. $7.5 \mathrm{~m} / \mathrm{yr}$ for ammonia, and $3.3 \mathrm{~m} / \mathrm{yr}$ for TKN, which varied greatly (26-75\%) from the values suggest in related literature, which are based on young constructed wetlands. The sedimentation pattern and vegetation density were monitored and correlated to the flow with the wetland cells, to determine that sediments were removed through both settling and filtration.
\end{abstract}




\section{Acknowledgements}

I would like to thank my supervisor Dr. Pascale Champagne for her guidance and support. I would like to thank Anna Crolla and Chris Kinsley for their knowledge of wetlands and their assistance with all aspects of the wetland research.

I would also like to express my appreciation of Dr. Paul Van Geel, who helped by demonstrating how to model the system. I would like to acknowledge Dr. Robert Kadlec for passing on his knowledge and his industry contacts to help with the analysis of the design models.

A project of this size could not be completed without the help of many people in the field (system setup and sampling). and in the laboratory (analyzing samples). I would like to express my sincerest appreciation for the efforts of Eric Brunet. a technician with the Ontario Rural Wastewater Center. for his help in the field, assembly of the sampling apparatus and his inventions that made sampling that much easier. I would also like to thank Keltouma Ouhna. a former technician with the Ontario Rural Wastewater Center. for her help with the analysis of samples and her organization of the lab and the summer students. Many summer employees, and exchange students. at the College d'Alfred should be recognized for their help. In the first year. Hachim Ahamat, and Andrea Kinsley helped with the setup of the system. Jeff Lalonde helped both in the field and in the laboratory. Ranjena Maloni. Miriam del Carmen Garcia Ramon. Jeremias Cordova Perez and Elisabeth Duchesne all helped with the analysis of samples in the laboratory. During the second year, Elysia Brunet helped with sampling the wetland and analysis of the samples. Kimberly Worl, Sandra Torales Noguéz, and Ismael Terrōn Melgerejo all helped with the analysis of samples. 
I would like to thank Natalie Gottschall, a Carleton University student in the department of Biology studying the same wetland, for her work sampling and analyzing samples.

I would like to acknowledge the financial support of South Nation Conservation, the Ontario Rural Wastewater Center of the College d'Alfred of the University of Guelph. I would also like to express my appreciation of the Dignard family for allowing the work to be done at the wetland and for their continued maintenance of the system.

Last, but certainly not least. I would like to thank my family and friends for their support and patience, without which I could never have done this. I would especially like to thank Meredith Dixon, for everything she did to help during the writing of the thesis. and Minna Koch for everything she did, from setup and teardown of the wetland sampling apparatus, to her help sampling. her analysis of samples and unwavering support through the whole process. 


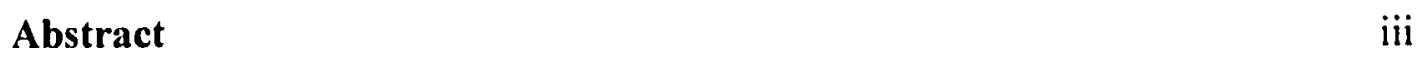

List of Tables $\quad$ ix

List of Figures $\quad$ xi

Chapter 1 Introduction

1.1 Objective 3

1.2 Scope of Study 4

1.3 Sample Site - Dignard Wetland, Embrun Ontario Canada 5

Chapter 2 Background 6

2.1 Types of Constructed Wetlands

2.2 Wastewater Treatment 9

2.2.1 Expected Streams 10

2.2.2 Primary Treatment of Wastewater for Wetland Systems $\quad 10$

2.2.3 Secondary Treatment (Constructed Wetlands) 11

2.2.4 Soil Liners $\quad 12$

2.2.5 Treatment Mechanisms in Constructed Wetlands $\quad 12$

2.2.5.1 Nitrogen Removal 13

2.2.5.2 Phosphorous Removal 14

2.2.5.3 $\mathrm{BOD}_{5}$ Removal $\quad 14$

2.2.5.4 Suspended Solids Removal 15

2.2.5.5 Pathogen Removal 16

2.2.6 Design Equations $\quad 16$

2.2.7 Agricultural Wastewater Treatment (Case Studies) 21

2.3 Constructed Wetlands in Canada 25

2.4 Tracers 26

2.4.1 Methods for Tracer Studies 26

2.4.1.1 Amount of Tracer 28

2.4.1.2 Concentration of Tracer 29

2.4.1.3 Determination of Tracer $\quad 30$

2.4.2 Dye and Chemical Tracers 31

2.4.3 Uses of Tracers 32

2.4.3.1 Flow Within Free Water Surface Wetlands 33

2.4.4 Previous Studies $\quad 34$

$\begin{array}{ll}\text { Chapter } 3 \text { Methodology } & 36\end{array}$

3.1 Site Description 36

3.2 Sampling Protocol $\quad 40$ 
3.2.1 Inlet and Outlet Samples 41

3.2.2 Water Column Samples 41

3.2.3 Sediment Samples 41

3.3 Tracer Study $\quad 42$

3.4 Analytical Procedures $\quad 43$

3.4.1 Total Suspended Solids (TSS) 43

3.4.2 Total Phosphorous (TP) 44

3.4.3 Ammonia $\quad 44$

3.4.4 Nitrate $\quad 44$

3.4.5 Total Kjeldahl Nitrogen (TKN) 44

3.4.6 Biological Oxygen Demand $\left(\mathrm{BOD}_{5}\right)$

3.4.7 Bromide $\quad 45$

3.5 Sediment Mapping and Vegetation Density Measurement 45

Chapter 4 Results and Discussion 46

4.1 Tracer Studies $\quad 46$

4.1.1 Overview $\quad 46$

4.1.2 Tracer Distribution $\quad 48$

4.1.2.1 First Vegetated Cell (FWS \#1) 49

4.1.2.2 Second Vegetated Cell (FWS \#2)

4.2 Removal of Constituents 54

4.2.1 Removal in Lagoon and Facultative Pond 55

4.2.2 Removal Within Wetland System 63

4.2.3 Removal of Constituents in Wetland Cells 69

4.2.3.1 First Vegetated Cell (FWS \#1) 69

4.2.3.2 Pond Cell (Pond) 81

4.2.3.3 Second Vegetated Cell (FWS \#2)

4.3 Sedimentation Depth and Vegetation Density in FWS \#1 96

$\begin{array}{ll}4.4 \text { Assessment of Design Models } & 100\end{array}$

4.4.1 TSS Removal $\quad 103$

$\begin{array}{ll}\text { 4.4.2 TP Removal } & 103\end{array}$

$\begin{array}{ll}4.4 .3 \text { Ammonia Removal } & 103\end{array}$

4.4.4 Nitrate Removal $\quad 106$

$\begin{array}{ll}\text { 4.4.5 TKN Removal } & 106\end{array}$

4.4.6 $\mathrm{BOD}_{5}$ Removal $\quad 106$

$\begin{array}{lr}4.5 \text { Engincering Significance } & 107\end{array}$

$\begin{array}{lr}\text { Chapter } 5 \text { Conclusions and Recommendations } & 109\end{array}$

$\begin{array}{ll}5.1 \text { Conclusions } & 109\end{array}$

$\begin{array}{ll}5.2 \text { Recommendations for further study } & 112\end{array}$

$\begin{array}{ll}\text { Chapter } 6 \text { References } & 114\end{array}$

$\begin{array}{ll}\text { Appendix A: Related Images } & 117\end{array}$ 
Appendix B: Raw Data

Appendix D: Model Calculations and Residence Time Distribution Curves 


\section{List of Tables}

2.1 Pollutant Removal Processes (Adapted from DLWC, 1998) 13

2.2 Typical Reed Kinetic Rate Constants (DLWC, 1998) 19

2.3 Typical Kadlec and Knight Rate Constants, Background

Concentrations and Temperature Correction Factors for

Various Parameters (Kadlec and Knight, 1996: Wallace, 2003) 21

2.4 Results from Pries and McGarry (2002) Wetland Study 23

2.5 Inlet and Outlet Concentrations Observed at Essex, Ontario

Constructed Wetland (CH2M Hill. 1997)

2.6 Inlet and Outlet Constituent Concentrations from

Thurston-Enriquez et al. (2004) 24

2.7 Inlet and Outlet Constituent Concentrations from the Oregon

State University Study (CH2M Hill, 1997)

4.1 Wastewater Constituent Concentrations ( $\pm 95 \% \mathrm{CI})$ in each Wetland Cell (2003)

64

4.2 Wastewater Constituent Concentrations $( \pm 95 \% \mathrm{CI})$ in each Wetland Cell (2003)

4.3 Calculated Rate Constants Compared to Values form the Literature 101

B-1 Sample Temperatures (2003) 122

B-2 Sample Temperatures (2003) 122

$\begin{array}{lll}\text { B-3 Sample pH (2003) } & 123\end{array}$

B-4 Sample pH (2004) 123

B-5 Sample Dissolved Oxygen Concentrations (2003) 124

B-6 Sample Dissolved Oxygen Concentrations (2004) 124

B-7 Sample TSS Concentrations (2003) 125

B-8 Sample TSS Concentrations (2004) 125

B-9 Sample TP Concentrations (2003) 126 
B-10 Sample TP Concentrations (2004) 126

B-11 Sample Ammonia Concentrations (2003) 127

B-12 Sample Ammonia Concentrations (2004) 127

$\begin{array}{llr}\text { B-13 Sample Nitrate Concentrations (2003) } & 128\end{array}$

$\begin{array}{ll}\text { B-14 Sample Nitrate Concentrations (2004) } & 128\end{array}$

$\begin{array}{lll}\text { B-15 Sample TKN Concentrations (2003) } & 129\end{array}$

B-16 Sample $\mathrm{BOD}_{5}$ Concentrations (2003) 130

B-17 Sample BOD $_{5}$ Concentrations (2004) 130

B-18 Water Balance: June 2003 131

B-19 Water Balance: July 2003

B-20 Water Balance: August 2003

B-21 Water Balance: September 2003 132

B-22 Water Balance: October 2003

$\begin{array}{lll}\text { C-1 Tracer Concentration Data } & 135\end{array}$

$\begin{array}{ll}\text { D-1 Model Calculations (2003) } & 137\end{array}$

$\begin{array}{ll}\text { D-2 } & \text { Model Calculations (2004) } \\ \end{array}$ 


\section{List of Figures}

$\begin{array}{lll}\text { 3.1 Dignard Constructed Wetland System } & 37\end{array}$

3.2 Sampling Locations in First Vegetated Wetland Cell (FWS \#1) 38

3.3 Sampling Locations in Aerobic Pond Cell (Pond cell) 39

3.4 Sampling Locations in Second Vegetated Wetland Cell (FWS \#2) 40

4.1 Simplified Hydrologic Analysis of Expected Wetland Flow Patterns 46

4.2 $\mathrm{C} / \mathrm{Co}$ Curves for the Three Tracer Tests 48

4.3 Tracer Distribution in FWS \#1 During the First Year of Study (2003) 50

4.4 Tracer Distribution in FWS \#1 During the Second Year of Study (2004) 52

4.5 Tracer Distribution in FWS \#2 During the First year of Study (2003) 54

4.6 TSS Concentrations in Lagoon, Facultative Pond and FWS \#1 Influent in both years of Study $\quad 58$

4.7 TP Concentrations in Lagoon, Facultative Pond and FWS \#I Influent in both years of Study

4.8 Ammonia Concentrations in Lagoon, Facultative Pond and FWS \#1 Influent in both years of Study

4.9 Nitrate Concentrations in Lagoon. Facultative Pond and FWS \#1 Influent in both years of Study

4.10 TKN Concentrations in Lagoon, Facultative Pond and FWS \#1 Influent in both years of Study

4.11 $\mathrm{BOD}_{5}$ Concentrations in Lagoon, Facultative Pond and FWS \#1 Influent in both years of Study

4.12 TSS Concentrations ( $\pm 95 \% \mathrm{CI})$ in FWS \#1 Water Column Samples (2003)

4.13 TP Concentrations $( \pm 95 \% \mathrm{CI})$ in FWS \#1 Water Column Samples (2003) 
4.14 Ammonia Concentrations $( \pm 95 \% \mathrm{Cl})$ in FWS \#1 Water Column Samples (2003)

4.15 TKN Concentrations $( \pm 95 \% \mathrm{CI})$ in FWS \#1 Water Column Samples (2003)

4.16 $\mathrm{BOD}_{5}$ Concentrations $( \pm 95 \% \mathrm{Cl})$ in FWS \#1 Water Column Samples (2003)

4.17 TSS Concentrations $( \pm 95 \% \mathrm{CI})$ in FWS \#1 Water Column Samples (2004)

4.18 TP Concentrations $( \pm 95 \% \mathrm{CI})$ in FWS \#1 Water Column Samples (2004) 76

4.19 Ammonia Concentrations $( \pm 95 \% \mathrm{Cl})$ in FWS \#1 Water Column Samples (2004)

4.20 $\mathrm{BOD}_{5}$ Concentrations $( \pm 95 \% \mathrm{CI})$ in FWS \#1 Water Column Samples (2004)

4.21 TP Concentrations ( $\pm 95 \% \mathrm{CI})$ in FWS \#1 Sediment Samples (2003)

4.22 Ammonia Concentrations $( \pm 95 \% \mathrm{Cl})$ in FWS \#1 Sediment Samples (2003)

4.23 TKN Concentrations ( $\pm 95 \%$ CI) in FWS \#1 Sediment Samples (2003)

4.24 TSS Concentrations ( $\pm 95 \%$ C.I) in Pond cell Water Column Samples (2003)

4.25 Ammonia Concentrations $( \pm 95 \% \mathrm{Cl})$ in Pond cell Water Column Samples (2003)

4.26 Nitrate Concentrations $( \pm 95 \% \mathrm{CI})$ in Pond cell Water Column Samples (2003)

4.27 $\mathrm{BOD}_{5}$ Concentrations $( \pm 95 \% \mathrm{CI})$ in Pond cell Water Column Samples (2003)

4.28 TP concentrations ( $\pm 95 \%$ CI) in Pond cell Sediment Samples (2003)

4.29 Ammonia concentrations $( \pm 95 \% \mathrm{Cl})$ in Pond cell Sediment Samples (2003)

4.30 Nitrate concentrations $( \pm 95 \% \mathrm{Cl})$ in Pond cell Sediment Samples (2003)

4.31 TKN concentrations $( \pm 95 \% \mathrm{CI})$ in Pond cell Sediment Samples (2003) 88 
4.32 TSS Concentrations ( $\pm 95 \%$ CI) in FWS \#2 Water Column Samples (2003) 89

4.33 TP Concentrations ( $\pm 95 \% \mathrm{CI})$ in FWS \#2 Water Column Samples (2003) 89

4.34 Ammonia Concentrations $( \pm 95 \% \mathrm{CI})$ in FWS \#2 Water Column Samples (2003) 90

4.35 BOD ; Concentrations $( \pm 95 \% \mathrm{CI})$ in FWS \#2 Water Column Samples (2003)

4.36 TSS Concentrations $( \pm 95 \%$ CI) in FWS \#2 Water Column Samples (2004) 92

4.37 Ammonia Concentrations $( \pm 95 \% \mathrm{CI})$ in FWS \#2 Water Column Samples (2004)

4.38 $\mathrm{BOD}_{5}$ Concentrations $( \pm 95 \% \mathrm{CI})$ in FWS \#2 Water Column Samples (2004)

4.39 TP Concentrations ( $\pm 95 \%$ CI) in FWS \#2 Sediment Samples (2003) 94

4.40 Ammonia Concentrations $( \pm 95 \% \mathrm{CI})$ in FWS \#2 Sediment Samples (2003)

4.41 Nitrate Concentrations ( $\pm 95 \% \mathrm{CI})$ in FWS \#2 Sediment Samples (2003) 95

4.42 TKN Concentrations $( \pm 95 \% \mathrm{Cl})$ in FWS \#2 Sediment Samples (2003) 95

4.43 Sediment Height (in cm) Within FWS \#1 (2004) 97

4.44 Vegetation density (out of 10) in FWS \#1 (2004) 98

4.45 Ammonia Concentrations in FWS \#1 (2003) 104

4.46 Ammonia Concentrations in FWS \#1 (2004) 105

4.47 Ammonia Concentrations in FWS \#2 (2003) 106

A-1 Aerial Photograph of Dignard Wetland (1996) 118

A-2 Aerial Photograph of Dignard Wetland (2003) 119

$\begin{array}{lll}\text { A-3 Filter Bucket in Wetland } & 120\end{array}$

$\begin{array}{lll}\text { A-4 Sampling Apparatus } & 120\end{array}$

D-1 TP Concentrations and Model Predictions in FWS \#1 (2003) 138 
D-2 TKN Concentrations and Model Predictions in FWS \#1 (2003) 139

D-3 $\mathrm{BOD}_{5}$ Concentrations and Model Predictions in FWS \#1 (2003) 139

D-4 TP Concentrations and Model Predictions in FWS \#I (2004) 140

D-5 $\quad \mathrm{BOD}_{5}$ Concentrations and Model Predictions in FWS \#1 (2004) $\quad 140$

D-6 TP Concentrations and Model Predictions in FWS \#2 (2003) 141

D-7 TKN Concentrations and Model Predictions in FWS \#2 (2003) 141

D-8 BOD 5 Concentrations and Model Predictions in FWS \#2 (2003) 142

D-9 TP Concentrations and Model Predictions in FWS \#2 (2004) 142

D-10 BOD; Concentrations and Model Predictions in FWS \#2 (2004) 143

D-11 Ammonia Concentrations and Model Predictions in FWS \#1 (2003) 143 


\section{CHAPTER 1 \\ INTRODUCTION}

The agricultural industry is important to the economy of Canada. As the demand for livestock products increases, so does the size of farms and the wastewater production from herds. Increased wastewater production is a topic of significant public concern.

The public concern with respect to wastewater production results from various factors. There are fewer active farmers currently working in eastern Ontario than in years past, but the demand for livestock products is increasing (Robson, 1999). This creates a situation where there are fewer farms, but the farms house more livestock units (LU). These farmers are expanding their agri-businesses into "mega farms" which have become so large that they cannot be ignored. At the same time, more people are moving to rural areas, trying to escape large city congestion, but bring with them a "big city attitude". People that have lived in rural areas for the majority of their lives have come to understand the requirements of farming, as well as the noise and odours associated with them. These people also understand that the farms will expand, and that they will have to accommodate this. The "big city attitude" brings along with it the resistance to the change. as well as the outrage with respect to some elements of farming realities such as appearance, odours, noise and potential pollution, to name a few.

While the appearance and noise of farms are problems that cannot be fixed (without significant technological advances), the odour and pollution problems can be remediated. Many odour and pollution issues can be associated with the nutrients in the animal wastes. These nutrients can be transported to local rivers, streams and groundwater aquifers in the area. Nutrient management plans are put in place to reduce the pollution associated with the wastes. Currently, the province of Ontario is developing 
standards for the treatment of agricultural wastes, where farms will be required to account for and treat any wastewater that will be discharged into the surrounding areas.

There are many different methods of treating the rural wastewater, which include: solid-liquid separation (a manure management option), aeration (reduction of ammonia and $\mathrm{BOD}_{5}$ concentrations), digestion (odour reduction, and pathogen destruction with the advantage of methane production as an energy source), and composting (volume reduction with a high nutrient fertilizer as a by-product). Some of these treatment options can be very high in cost ( $\$ 15$ per head of cattle, $\$ 10$ per pig) (Robson, 1999). Most of the practices involve intensive labour, which is much more than is already available at oftenunderstaffed farms. Since farmers have no control over the price of the products that are produced, they often cannot recuperate the costs associated with the treatment technology, or the added labour.

Often convenient solutions for farmers are passive treatment systems. These systems can be easily operated, and the capital, as well as the operation and maintenance costs. will be lower than more active treatment methods. Systems can be setup such that all of the components are electronically controlled and there is only a need to verify the operation, or the control can be setup such that only a pump needs to be started and stopped at regular intervals (a task that will not take much labour). Constructed wetlands are an excellent option for nutrient management on farms. They are easily operated. relatively inexpensive, when the required land is available, and as an added bonus, they typically attract wildlife to the area. 


\subsection{OBJECTIVES}

For as many years as wetlands have been in use, people have studied them to better understand the processes at work. The goal is to design more efficient systems that require less overall land area. In the past, tracer studies have been conducted (Kadlec, 1994: Scmid et al., 2004; Bowmer, 1987) to analyze actual wetland retention times, but there has not been much work at analyzing flow patterns within the wetland cells. Many of the parameters that are currently used to design wetlands are estimated from large monitoring databases of wetlands which have been studied in the first two or three years of operation, with little data from mature systems (systems operating for more than five years). When a system is first built, the vegetation that is planted is generally distributed evenly throughout the cell, with controlled types of vegetation planted, there are no sediments on the bottoms of the cells, phosphorous adsorption sites are available throughout the soil, bacterial populations are immature, and there is a minimal animal and insect larval activity within the cells. During the years of wetland operation, the bacterial cultures mature. Vegetation propagates in some area of the cells and stops growing in others, resulting in uneven vegetation of the cell. As well, other local plant species will invade the cell with time. Sediments start to deposit within the wetlands cells, creating preferential flow channels. Phosphorous adsorption sites begin to become depleted and blocked by the buildup of sediments and bacteria, reducing the phosphorous removal potential of the system. Animals begin to build nests in the vegetation of the cells, and insects begin to lay eggs in the wastewater, the resulting larvae can begin to prey on the bacteria of the system, reducing the efficiency of bacterial treatment. 
The purpose of this study was to understand the flow pathways within a mature (operating for nine years) constructed wetland treating dairy cattle manure runoff and milkhouse washwater over two operating seasons, and to determine if preferential pathways have been established due to plant growth and uneven settling of solids. This study also aimed to examine the inlet and outlet characteristics of the wetland to determine if different flow conditions would result in different treatment capacities, as well as determining the applicability of literature design nutrient removal rate constants. and existing design models, to the wetland employed in this study.

\subsection{SCOPE OF STUDY}

In order to attain the study objectives, the work that was undertaken during the two-year study included the following:

- Three separate tracer studies to understand the flow dynamics within the constructed wetland;

- Two years of water column sampling and analysis to determine the treatment efficiency of each wetland cell;

- One year of pore water sampling and analysis within the sediment zones to assist in the determination of the treatment efficiency of each wetland cell:

- Mapping of sediments and vegetation of the first vegetated wetland cell to determine sedimentation patterns; and,

- Field and lab analysis of the water samples. 


\subsection{SAMPLE SITE - DIGNARD WETLAND, EMBRUN, ONTARIO, CANADA}

The constructed wetland used in this study was constructed on the Dignard dairy farm in 1994 and was designed to treat the wastewater from a herd of 190 livestock units. The dairy operation produces three types of wastewaters: washwater from the cleaning of milkhouse equipment, stormwater runoff from the cattle exercise yard and liquid runoff from the solid manure pile. Prior to the construction of the wetland, the liquid manure runoff and the milkhouse washwater were stored in a lagoon and periodically spread onto cropland, while the runoff from the exercise yard was not collected. The farmer was searching for a method to treat the liquid wastewater, which did not require application on to cropland.

The constructed wetland was designed such that the pre-existing lagoon continued to be used to collect the runoff from the solid manure pile. The manure pile runoff and milkhouse washwater was pumped into a facultative pond where it would mix with the runoff from the exercise yard, which was collected using an overland flow system. The effluent from the facultative pond was then pumped into a marsh-pond-marsh constructed wetland system. A vegetated filter, which used barley as the cover crop, was used as a final polishing stage for the constructed wetland effluent. 


\section{CHAPTER 2 \\ BACKGROUND}

Natural wetlands have been employed in the mitigation of wastewaters for many years. Wetlands can remove pathogens, neutralize $\mathrm{pH}$, and decrease concentrations of harmful chemicals and pollutants. Constructed wetland treatment has been a topic of research and development since the late 1970s. Constructed wetlands, which are designed to imitate natural wetlands, are currently used to treat many pollutant streams, including: leachate from municipal solid waste (MSW), acid rock drainage (ARD), landfill leachate, urban runoff, as well as wastewater streams from photo developing labs, textile plants, rendering plants, pulp mills and refineries (Watson and Hobson, 1991).

Passive treatment systems, such as constructed wetlands, offer low-cost, easily operated and efficient treatment alternatives. Other active treatment systems for wastewater streams involve the addition of chemicals or mechanical works to produce an effluent that meets regulatory discharge standards. The costs associated with these types of systems can be high. The chemical additives must be purchased, and since they are used up in the process, they must be constantly replenished. The equipment that is involved in the different steps of the treatment process must also be purchased, and maintained. The design of the facility must include extra flow channels in each step of the treatment process so that some channels can be taken off-line for maintenance purposes, while maintaining treatment objectives. On-site operation and maintenance staff must also be employed. The costs associated with a constructed wetland include: the purchase of the land, labor to build the wetland, and staffing for the monitoring of the influent and effluent to ensure that the treated effluent complies with discharge guidelines. 
Typically, constructed wetlands do not require frequent maintenance of machinery, since the number of mechanical systems is generally minimal. The absence of chemical addition means that there are no employees required to handle chemical stores. The only maintenance required is the periodic testing of the influent and effluent to ensure compliance with discharge criteria. Wetlands can also be designed to treat wastewater streams as efficiently as active treatment systems. The reduced amount of maintenance, ease of operation and treatment efficiency demonstrate the advantage of passive treatment systems as a convenient treatment alternative that farmers can utilize as a nutrient management option.

\subsection{TYPES OF CONSTRUCTED WETLANDS}

There are two different types of constructed wetlands in operation. free water surface (FWS) and subsurface flow (SSF) wetlands (Kadlec and Knight, 1996). A free water surface wetland was the focus of this study. FWS wetlands are systems where the flow of the wastewater is above the sediment zone. These wetlands can remain unvegetated (pond cells) or can be planted with emergent vegetation (reeds, sedges, grasses), or floating vegetation (duckweed). SSF wetlands are systems where the wastewater flows through a porous media. These systems can remain unvegetated or be planted with similar plants as the emergent vegetation for FWS wetlands.

There are a number of factors involved in the design of wetlands. One must assess the objectives of the treatment, the nature of the expected wastewater stream, the constituents that will require treatment, the criteria or guidelines that will govern effluent standards and any safety factors involved. The type of treatment that is to be carried out by the wetland is also a factor. Wetlands can be used as a primary treatment method. 
employed as a polishing step after a more active treatment, or be part of a larger system where the wetland effluent is expected to go through subsequent processes. The type of system, surface or subsurface, and the configuration of the system, channels in parallel or series, must also be considered.

Surface wetlands are designed to sustain life as well as convey water flow. The soil has to be a suitable medium for plant growth, as well as stable enough that it will not erode. There must be a liner or low permeability barrier soil that will prevent leaching through the soil. Water depth is another issue, if the water is too deep. wind driven aeration will not provide oxygen to greater depths, and these areas will not be able to support aerobic bacteria. The minimum and maximum depths of flow also affect the choice of plants for the wetland. Flow channels should also generally be setup to induce a plug flow through the wetland cells (Kadlec and Knight, 1996).

There are many factors that govern the treatment efficiency of the wetland. The hydraulic loading, ambient and water temperatures. flora and fauna within the wetland, types of pollutants, and exposure time are just some of the parameters involved (Kadlec and Knight, 1996). Uncertainties, such as fluctuations in design flows, also have an impact. The volumes of flow, as well as the concentration of pollutants, can change on a daily basis and rainfall, drought. etc. are of great importance. Hydraulic overloads, rainfall cvents, and snowmelt increase the flow into the wetland, diluting the wastewater stream, which can interfere with processes within the wetland that are more efficient with more concentrated streams, as well as increasing the flow rate and reducing the residence time within the wetland cells (Chazarence et al., 2003). These problems must be overcome to create an efficient treatment system. 
Since wetland treatment has not been studied over an extended period of time, there are some uncertainties associated with the life expectancy of the treatment system. Each wetland must be periodically tested to establish whether the efficiency remains consistent with time.

\subsection{WASTEWATER TREATMENT}

In recent years, farmers have had growing concerns with respect to wastewater nutrient management. The large volumes of wastewater from their livestock and production facilities must be treated to minimize the potential contamination of receiving waters (Hill et al., 2000). This can be achieved through the use of natural systems such as wetlands. To protect the wetland system, the wastewater should be pre-treated to reduce the nutrient loads to manageable levels. The engineered natural treatment systems can be classified into two categories, which depend upon the desired treatment objectives:

1) Primary treatment includes: anaerobic lagoons, facultative ponds. or other systems that are designed to handle large nutrient loading.

2) Secondary treatment includes: wetland polishing of low nutrient lagoon and pond effluents.

Factors that need to be considered in the design of these wetlands are the discharge limits, and required safety factors. Discharge limits may be regulated by municipalities or government agencies with the goal of public and safety, while safety factors based on the size of the wetland must also be specified to ensure that large rainfall events will not cause the wetland to overflow, which would allow untreated wastewater to enter directly into a receiving body of water. 


\subsubsection{Expected Streams}

Wastewater streams that can discharge to wetlands are highly variable, and the source greatly impacts the composition and flow of the wastewater. Different livestock operations generate wastewaters with different nutrient characteristics (based on the diet of the animals) (McKee and Brooks, 1994). Farms usually collect the wastewater in piles and allow rainwater to carry the wastewater to the wetlands. Thus, precipitation patterns of the area will change the concentrations of the nutrients in the wastewater.

The influent wastewater can be separated into different categories. The Council for Environmental Quality had noted three classes of sewage based upon the concentrations of phosphorous and $\mathrm{BOD}_{5}$. With regards to phosphorous, the council rates concentrations of less than $2 \mathrm{mg} / \mathrm{L}$ as weak, $5 \mathrm{mg} / \mathrm{L}$ as medium, and $10 \mathrm{mg} / \mathrm{L}$ as strong. $\mathrm{BOD}_{5}$ ranges are much higher, a weak sewage will have concentrations of less than 100 $\mathrm{mg} / \mathrm{L}, 200 \mathrm{mg} / \mathrm{L}$ will rate as medium and $450 \mathrm{mg} / \mathrm{L}$ as a strong sewage. Nitrogen, usually reported as Total Kjeldahl Nitrogen (TKN), has been found in agricultural wastewater to have concentrations ranging from 10 to $183 \mathrm{mg} / \mathrm{L}$. The bacteria in agricultural wastewater have been found to range from $10^{5}$ to $10^{7} / 100 \mathrm{ml}$ in terms of total coliform, and $5 \times 10^{4}$ to $10^{6} / 100 \mathrm{ml}$ for fecal coliform (McKee et al.. 1994).

\subsubsection{Primary Treatment of Wastewater for Wetland Systems}

Primary treatment of wastewater generally takes place in anaerobic lagoons and facultative ponds. These systems are designed to remove high nutrient concentrations from the system in a short period of time. Treatment in these ponds is efficient, while there are high concentrations of wastewater constituents, but as concentrations of the constituents decrease, the treatment efficiency typically decreases as well. 
Anaerobic lagoons receive high nutrient loads, often sufficient to deplete all of the dissolved oxygen in the system. The high surface area and low velocity of lagoons are ideal for the removal of suspended solids. As the solids settle, other constituents in the wastewater bind to the settling particles and are also removed. The remainder of the reduction in constituent concentrations results from the anaerobic treatment of the wastewater.

Facultative ponds receive a wastewater stream with a weaker nutrient loading than anaerobic lagoons. The surface area of the pond is large enough, and the nutrient concentrations low enough, to allow shallow depths of the pond to function under aerobic conditions. The settling of solids brings more of the organic fraction to the depths of the pond where anaerobic processes will be prevalent. Ponds achieve efficient treatment due to these two distinct effective treatment zones.

\subsubsection{Secondary Treatment (Constructed Wetlands)}

Standard free water surface wetland designs involve a set of channels with flow controlled by exit structures such as weirs. Another option for the layout of a wetland would be a system where the flow passes through a marsh stage. The water then continues to a pond for further settling of the solids and aeration of the wastewater, with a final marsh system acting as a polishing stage (Kadlec and Knight, 1996).

Design criteria for optimum treatment are detention times of 5-14 days to allow for the settling of suspended solids, as well as the establishment of bacterial and chemical reaction kinetics. The maximum BOD loading rate should be $80 \mathrm{~kg} /$ ha-day (Kirby, 2002), to maintain aerobic conditions within the system. The water depths within the wetland should be between 0.1 and $0.8 \mathrm{~m}$ (Kirby, 2002) to ensure that wind-induced aeration can 
reach the lower depths of wetland. If the depth were shallower, the wetlands would run a risk of drying out, which could result in a loss of vegetation. If the flow were too high, the soil and sediments would get carried off in the flow and solids would not be able to settle out (Kirby, 2002).

\subsubsection{Soil}

The soil of the wetland can also have an effect on treatment, by adsorbing some of the contaminants. The effectiveness of the soil adsorption of phosphorous in the wastewater stream is dependant upon the type of soil, the density of the soil, its permeability, depth, slope of the bed, water level and the hydraulic gradients within the system. Clogging of the pore space within the soil can lead to a reduction in adsorption processes. Bacteria from the wastewater typically mix with the bacteria in the wetland. These bacteria grow quickly in the nutrient rich media to form large flocs. These flocs then settle and reach the sediment layer. Once the soil is covered and the aerobic bacteria have depleted the dissolved oxygen, anaerobic bacteria start to form a slime layer over the settled matter. This slime layer resists decomposition and deterioration, which could create a barrier between the soil and the wastewater and reduce the efficiency of the wetland (Brooks, 1988).

\subsubsection{Treatment Mechanisms in Constructed Wetland Systems}

Biological, physical and chemical treatment processes occur within the wetland cells. Table 2.1 outlines the processes at work in a FWS wetland for the removal of various constituents. 
Table 2.1 Pollutant Removal Processes (adapted from DLWC, 1998)

\begin{tabular}{|l|l|}
\hline \multicolumn{1}{|c|}{ Pollutant } & \multicolumn{1}{c|}{ Removal Mechanisms } \\
\hline $\begin{array}{l}\text { Organic Material } \\
\text { (measured as BOD) }\end{array}$ & biological degradation, sedimentation, microbial uptake \\
\hline $\begin{array}{l}\text { Organic } \\
\text { Contaminants (e.g. } \\
\text { pesticides) }\end{array}$ & $\begin{array}{l}\text { adsorption, volatilization, photolysis, biotic/abiotic } \\
\text { degradation }\end{array}$ \\
\hline Suspended Solids & sedimentation, filtration \\
\hline Nitrogen & $\begin{array}{l}\text { sedimentation, ammonification, nitrification/denitrification, } \\
\text { microbial uptake, plant uptake, volatilization }\end{array}$ \\
\hline Phosphorous & $\begin{array}{l}\text { sedimentation, filtration, adsorption, plant \& microbial } \\
\text { uptake }\end{array}$ \\
\hline Pathogens & $\begin{array}{l}\text { natural die-off, sedimentation, filtration, predation. UV } \\
\text { degradation, adsorption }\end{array}$ \\
\hline Heavy Metals & sedimentation, adsorption, plant uptake \\
\hline
\end{tabular}

\subsubsection{Nitrogen Removal}

The contaminant of greatest concern in agricultural wastewater is nitrogen. which is often evaluated as Total Kjeldahl Nitrogen (TKN) and a measure of organic nitrogen species and ammonia. Wetland treatment can reduce nitrogen concentrations through plant and bacterial activities. Ammonia nitrification (ammonia being oxidized to nitrate) is performed near the nodules at the roots of the plant structures by nitrifying bacteria: Nitrosomas and Nitrobacter, respectively. Strict aerobic bacteria, which consume oxygen to oxidize the ammonia to nitrite, control this process; the nitrite is then subsequently oxidized further to nitrate. Nitrate can then be reduced to free nitrogen by denitrifying bacteria. This process begins when the dissolved oxygen in the system is reduced to zero, bacteria then use the oxygen in the nitrate molecule as an electron acceptor. This process will only occur in the presence of available organic carbon under anoxic conditions (Kadlec and Knight, 1996). 


\subsubsection{Phosphorous Removal}

The mechanisms of phosphorous removal in wetlands include: adsorption, complexation, plant uptake, immobilization onto organic matter and chemical precipitation.

The main method of phosphorous removal is adsorption onto the soil. Dispersible soils reduce the efficiency of the phosphorous removal, while sandy soil tends to increase the removal (Begg et al., 2001). The highest removal of phosphorous is generally observed in wetlands lined with clays rich in iron, aluminum or calcium due to the phosphorous adsorption potential of these sites (Watson and Hobson, 1991). On average, the removal efficiency of phosphorous in a wetland is above $87 \%$ (Reddy et al., 2001). Vegetation in the wetland will uptake small amounts of phosphorous through their root zone, and as these plants die and decompose, the phosphorous will be reintroduced into the system.

\subsubsection{3 $\mathrm{BOD}_{5}$ Removal}

In a wetland, there are two methods of $\mathrm{BOD}_{5}$ removal. Larger organics are removed by filtration and settling, while the remaining are removed through microbial activity. In tests involving wetlands with and without vegetation, BOD removal was found to be similar (Hench et al, 2003), indicating limited plant involvement in BOD removal.

Since aerobic microbial activity is involved in $\mathrm{BOD}_{5}$ removal, dissolved oxygen is required. Aeration can be achieved through wind in shallower wetlands, or hydraulically induced turbulence. Mechanical aerators can also be used, but these would involve a more active approach to the design of the system, leading to increased 
operational costs. Covers placed on the system, such as plant overgrowths, or ice in the colder months will block any wind-induced aeration and the system may become anaerobic.

The $\mathrm{BOD}_{5}$ removal efficiencies of the system are increased when the wetland is mature, as there are more established bacterial colonies to remove the $\mathrm{BOD}_{5}$. Higher organic loading will also generally increase the efficiency, since there will be a greater quantity of organic substrate to feed the bacteria. If the organic loading is too high, however, the dissolved oxygen will not be available in sufficient quantity to sustain the degradation of the organic material, and this will cause aerobic bacteria to become less active, consequently decreasing the $\mathrm{BOD}_{5}$ removal (Watson and Hobson, 1991). If the wetland is designed adequately, BOD removals of over $90 \%$ can be achieved (Merlin et al., 2002).

\subsubsection{Suspended Solids Removal}

Suspended solids within the wastewater must be removed through filtration and settling. The detention time must allow for the settling of coarse to medium sized particles in the basins, while the plants and the soil can filter smaller particles. Fecal coliform, as well as nitrogen and phosphorous tend to be associated with the smaller fraction of suspended solids, and the removal of these solids could, consequently, result in the removal of some of those contaminants (Watson and Hobson, 1991). 
The removal efficiency related to suspended solids varies depending on the design of the system. A system with dense plant life can act as a better filter for smaller particles, whereas a system with sparse plant growth will not remove many of the smaller particles. The effluent from the wetland could also pass through a filter that will remove some of the solids.

\subsubsection{Pathogen Removal}

The removal of pathogens and bacteria in a wetland is crucial. If bacteria exit the wetland system in high concentrations, the bacteria could potentially impact the receiving water body, and ultimately, the health of the public. Bacteria are removed from the water through chemical reactions, radiation, sedimentation, filtration and predation by zooplankton. These removal processes require an adequate retention time for the destruction of bacteria (Watson and Hobson, 1991).

\subsubsection{Design Equations}

There are three main model equations that have been developed to describe the removal rates of contaminants within FWS wetlands: Crites and Tchobanoglous; Reed. Crites and Middlebrooks; and Kadlec and Knight. These models were defined using a database containing monitoring information from many constructed wetlands, most of which contained data for the first three years of operation (young wetlands). The database of wetlands was used to determine which reactor models best described the treatment processes occurring within wetland the cells, and suggested parameter values and temperature correction factor. The wetlands in the database, mainly treated domestic wastewater, however, in 1997 the Gulf of Mexico program determined the parameter 
value for the Kadlec and Knight model with respect to higher concentration agricultural wastewaters (CH2MHill and Payne, 1997).

The Crites and Tchobanoglous model (Crites and Tchobanoglous, 1998) assumes that a wetland acts as four completely stirred tank reactors (CSTR) in series. This assumption is used to account for the dispersion of the wastewater as well as the preferential flow pathways within the wetland cells. This equation is only applicable to describe $\mathrm{BOD}_{5}$ removal.

$$
t=\frac{V}{Q}=\left[\frac{1}{\left(C_{n} / C_{0}\right)^{1 / 4}}-1\right] \times \frac{4}{k_{0}}
$$

Where: $\quad t \quad$ is the detention time (days)

$\mathrm{V}$ is the volume of the treatment system $\left(\mathrm{m}^{3}\right)$

Q is the flow rate of the wastewater stream $\left(\mathrm{m}^{3} / \mathrm{d}\right)$

$\mathrm{C}_{\mathrm{n}} \quad$ is the effluent $\mathrm{BOD}_{5}$ concentration $(\mathrm{mg} / \mathrm{L})$

$\mathrm{C}_{\mathrm{o}} \quad$ is the influent $\mathrm{BOD}_{5}$ concentration $(\mathrm{mg} / \mathrm{L})$

$k_{0} \quad$ is the overall $\mathrm{BOD}_{5}$ removal constant $\left(\right.$ days $\left.^{-1}\right)$

The value used for $k_{0}\left(1.01 \mathrm{~d}^{-1}\right.$ for $\left.20^{\circ} \mathrm{C}\right)$ must be corrected using Equation 2-2 for the coldest temperature expected during the operation of the system. 


$$
\frac{k_{2}}{k_{1}}=\theta^{\left(T_{2}-T_{1}\right)}
$$

Where: $\quad k_{1} \quad$ is the $B O D_{j}$ removal constant at temperature $T_{1}\left(\right.$ days $^{-1}$ )

$\mathrm{k}_{2} \quad$ is the $\mathrm{BOD}_{5}$ removal constant at temperature $\mathrm{T}_{2}\left(\right.$ days $^{-1}$ )

$\theta \quad$ is the temperature correction factor

(1.02-1.06 is recommended)

$T_{1} \quad$ is the operating temperature $T_{1}\left({ }^{\circ} \mathrm{C}\right)$

$\mathrm{T}_{2} \quad$ is typically $20^{\circ} \mathrm{C}$

The second method of wetland sizing is the Reed, Crites and Middlebrooks model (Reed et al.. 1995). This method is based on first order reaction kinetics in a plug flow reactor. The model is applicable to those pollutants that are primarily removed via biological processes $\left(\mathrm{BOD}_{5}, \mathrm{NH}_{3}\right.$, and $\left.\mathrm{NO}_{3}{ }^{-}\right)$. The Crites and Tchobanoglous method recommends that the Reed, Crites and Middlebrooks model be used for both nitrogen and TSS removal equations (Wallace, 2003). The size of the wetland can be determined using equation (2-3). 


$$
A=\frac{Q_{u r v} \ln \left(C_{i} / C_{\mathrm{v}}\right)}{K_{\mathrm{v}, T} \times d_{w}}
$$

Where: A is the surface area of the Wetland $\left(\mathrm{m}^{2}\right)$

Quve is the average flow rate $\left(\mathrm{Q}_{\text {in }} / \mathrm{Q}_{\text {out }}\right)\left(\mathrm{m}^{3} / \mathrm{d}\right)$

$\mathrm{K}_{\mathrm{v}, \mathrm{T}}$ is the first order rate constant at temperature $\mathrm{T}^{\circ} \mathrm{C}\left(\right.$ days $\left.^{-1}\right)$

$d_{w} \quad$ is the depth of the wetland cell (m)

$\mathrm{C}_{\mathrm{c}} \quad$ is the effluent $\mathrm{BOD}_{\mathfrak{s}}$ concentration $(\mathrm{mg} / \mathrm{L})$ for $\mathrm{BOD}_{5}$ removal

$\mathrm{C}_{\mathrm{e}}$ is the effluent ammonia concentration $(\mathrm{mg} / \mathrm{L})$ for nitrification

$\mathrm{C}_{\mathrm{c}}$ is the effluent nitrate concentration $(\mathrm{mg} / \mathrm{L})$ for denitrification

$\mathrm{C}_{\mathrm{i}}$ is the influent $\mathrm{BOD}_{5}$ concentration $(\mathrm{mg} / \mathrm{L})$ for $\mathrm{BOD}_{5}$ removal

$\mathrm{C}_{\mathrm{i}}$ is the influent $\mathrm{TKN}$ concentration $(\mathrm{mg} / \mathrm{L})$ for denitrification

$\mathrm{C}_{\mathrm{i}}$ is the influent nitrate concentration ( $\mathrm{mg} / \mathrm{L}$ ) for denitrification

The rate constant can be determined for the varying temperatures in the wetland using Equation (2-2) with the values of $k_{v .20}$ and $\theta$ from Table 2.2.

Table 2.2 Typical Reed Kinetic Rate Constants (DLWC, 1998)

\begin{tabular}{|l|c|c|}
\hline Parameter & $\mathbf{k}_{\mathrm{v}, 20}$ & $\mathbf{0}$ \\
\hline $\mathrm{BOD}_{5}$ & 0.678 & 1.06 \\
\hline Nitrification $\left(\mathrm{NH}_{3}\right.$ removal) & 0.2187 & 1.048 \\
\hline Denitrification & 1.0 & 1.15 \\
$\left(\mathrm{NO}_{3}^{-}\right.$-removal) & & \\
\hline
\end{tabular}

The removal of TSS is not considered a critical component of wetland sizing in the Reed, Crites and Middlebrooks model. A removal equation for TSS (Equation 2-4) has been proposed from existing FWS data (DLWC, 1998). 


$$
C_{\mathfrak{c}}=C_{1}[0.1139+0.00213(H L R)]
$$

Where: $\quad C_{\mathfrak{c}} \quad$ is the effluent TSS concentration $(\mathrm{mg} / \mathrm{L})$

$\mathrm{C}_{\mathrm{i}}$ is the influent TSS concentration $(\mathrm{mg} / \mathrm{L})$

HLR is the hydraulic loading rate $(\mathrm{cm} / \mathrm{d})$

The third model proposed for wetland sizing is the Kadlec and Knight model (Kadlec and Knight, 1996). This method, like the Reed model, assumes that the wetland acts as a plug flow reactor. Reed et al. (1995) and Crites and Tchobanoglous (1998) suggest that the Kadlec and Knight model be employed for phosphorus removal. The Kadlec and Knight model introduces the concept of background nutrient concentrations to account for limiting values. The rate constants that are used in the model are from a large database, which covers many geographical locations and loading rates.

$$
\begin{aligned}
& \ln \left(\frac{C_{i}-C^{*}}{C_{i}-C^{*}}\right)=-\frac{K_{t . I}}{q} \\
& q=\frac{365 \times Q}{A}
\end{aligned}
$$

Where: $\quad C_{c} \quad$ is the outlet concentration $(\mathrm{mg} / \mathrm{L})$

$\mathrm{C}_{\mathrm{i}} \quad$ is the effluent concentration $(\mathrm{mg} / \mathrm{L})$

$\mathrm{C}^{*} \quad$ is the background concentration $(\mathrm{mg} / \mathrm{L})($ table 2.3$)$

$\mathrm{K}_{\Lambda, T}$ is the first order aerial rate constant at temperature $\mathrm{T}^{\mathrm{C}} \mathrm{C}(\mathrm{m} / \mathrm{yr})$

$\mathrm{q} \quad$ is the hydraulic loading rate $(\mathrm{m} / \mathrm{yr})$

Q is the flow rate through the wetland $\left(\mathrm{m}^{3} / \mathrm{d}\right)$

A is the surface area of the wetland $\left(\mathrm{m}^{2}\right)$ 
The aerial rate constant can be adapted for the varying temperatures within the wetland using Equation (2-2) with the values of $\mathrm{k}_{\mathrm{v} .20}$ and $\theta$ listed in Table 2.3.

Table 2.3 Typical Kadlec and Knight Rate Constants, Background Concentrations, and Temperature Correction Factors for Various Parameters (Kadlec and Knight, 1996; Wallace, 2003)

\begin{tabular}{|l|c|c|c|}
\hline \multicolumn{1}{|c|}{ Parameter } & $\begin{array}{c}\text { Background } \\
\text { Concentration } \mathrm{C}^{*} \\
(\mathbf{m g} / \mathbf{L})\end{array}$ & $\mathbf{K}_{\mathbf{A , 2 0}}(\mathbf{m} / \mathbf{y r})$ & $\mathbf{0}$ \\
\hline $\mathrm{BOD}_{5}$ & $\begin{array}{c}3.5+0.053 \mathrm{C}_{\mathrm{i}} \\
(0 \leq \mathrm{C}<200 \mathrm{mg} / \mathrm{L})\end{array}$ & 34 & 1 \\
\hline $\mathrm{TSS}$ & $\begin{array}{c}5.1+0.16 \mathrm{C}_{\mathrm{i}} \\
(0.1 \leq \mathrm{C}<807 \\
\mathrm{mg} / \mathrm{L})\end{array}$ & $1000^{\mathrm{a}}$ & 1 \\
\hline Organic-N $_{\mathrm{NH}_{4}-\mathrm{N}}$ & 1.5 & 17 & 1.05 \\
\hline $\mathrm{NO}_{\mathrm{x}}-\mathrm{N}$ & 0 & 18 & 1.04 \\
\hline Total-N & 0 & 35 & 1.09 \\
\hline Total-P & 1.5 & 22 & 1.05 \\
\hline
\end{tabular}

a A rough unsubstantiated estimate; solid settling velocity, $w(\mathrm{~m} / \mathrm{d})$, is preferred, where $k_{A, T}$ is replace with $w$.

\subsubsection{Agricultural Wastewater Treatment (Case Studies)}

There have been many studies performed on wetlands that treat agricultural wastewaters. These studies have been performed in different countries and climates, and all of the studies have resulted in substantial reductions of constituent concentrations. Different types of wetland systems were used in different studies, as well as different types of vegetation, or in some cases, no vegetation.

Drizo et al. (2004) monitored a wetland system in Vermont, USA that was treating barnyard runoff and milkhouse washwater. The treatment system consisted of two subsurface wetland cells in parallel following two anaerobic tanks. One of the wetland cells was vegetated with cattails, while the other remained unvegetated. The purpose of the study was to determine the difference in treatment efficiency of vegetated 
and unvegetated SSF wetland cells with a 5-day detention time. The study also observed the difference in treatment with and without aeration of the wetland cells. At the end of the study, the $\mathrm{BOD}_{5}$ removal was determined to be $90 \%$ in both the vegetated and unvegetated cells, and the TSS removal was determined to be $97 \%$ in the vegetated cell and $87 \%$ in the unvegetated cell with aeration. Without aeration, the $\mathrm{BOD}_{5}$ removal decreased to $50 \%$ in the vegetated cell and $58 \%$ in the non-vegetated cell, the TSS removal also decreased to $76 \%$ in both cells. Ammonia and phosphorous removal was low in both of the cells, but the vegetated cell demonstrated a slight increase in ammonia removal during aeration.

Pries and McGarry (2002) monitored two constructed wetlands treating feedlot storm water runoff from dairy operations in Manitoba, Canada. The first wetland consisted of a single FWS cell with a surface area of 0.5 ha, and a depth of $0.3 \mathrm{~m}$, vegetated with cattails. The second wetland consisted of two FWS cells each with a surface area of 0.5 ha and a depth of $0.3 \mathrm{~m}$, vegetated with cattails. The results from monitoring are presented in Table 2.4. Each of the systems demonstrated good removal of the wastewater constituents, especially nitrogen species and $B O D_{5}$. The analysis of this wetland resulted in variations in the wastewater parameter concentrations. In Table 2.4, the $\mathrm{BOD}_{5}$ and Ammonia in the first wetland and the TSS and TP in the second system demonstrate variability in the influent and effluent concentrations. This was expected and understood in natural systems due to the variable precipitation, which tends to dilute the wastewater, and evapotranspiration, which tends to increase wastewater concentrations. 
Table 2. 4 Results from Pries and McGarry (2002) Wetland Study

\begin{tabular}{|c|c|c|c|c|}
\hline & \multicolumn{2}{|c|}{ First Wetland (One FWS Cell) } & \multicolumn{2}{c|}{$\begin{array}{c}\text { Second Wetland (Two FWS } \\
\text { Cells) }\end{array}$} \\
\hline Nutrient & $\begin{array}{c}\text { Inlet } \\
\text { Concentration } \\
(\mathrm{mg} / \mathrm{L})\end{array}$ & $\begin{array}{c}\text { Outlet } \\
\text { Concentration } \\
(\mathrm{mg} / \mathrm{L})\end{array}$ & $\begin{array}{c}\text { Inlet } \\
\text { Concentration } \\
(\mathrm{mg} / \mathrm{L})\end{array}$ & $\begin{array}{c}\text { Outlet } \\
\text { Concentration } \\
(\mathrm{mg} / \mathrm{L})\end{array}$ \\
\hline TSS & 70 & 12 & $600-20$ & $200-10$ \\
\hline BOD 5 & $81-5$ & $18-6$ & 124 & 13 \\
\hline TP & 4 & 3 & $9-8$ & $9-7.5$ \\
\hline Ammonia & $25-4$ & 0.2 & 27 & 1 \\
\hline TKN & 39 & 6 & 81 & 12 \\
\hline
\end{tabular}

Monitoring was performed at a farm in Essex, Ontario Canada (CH2MHill and Payne, 1997), where a wetland was used to treat barnyard runoff and milkhouse washwater. The constructed wetland consisted of a $600 \mathrm{~m}^{2}$ serpentine channel that was planted with cattails. The inlet and outlet nutrient concentrations from the study are presented in Table 2.5. This wetland demonstrated an excellent removal of phosphorous and nitrogen species, but there was little reduction in $\mathrm{BOD}_{5}$ concentration.

Table 2.5 Inlet and Outlet Concentrations Observed at Essex, Ontario Constructed Wetland (CH2M Hill and Payne. 1997)

\begin{tabular}{|c|c|c|}
\hline Nutrient & $\begin{array}{c}\text { Inlet Concentration } \\
(\mathrm{mg} / \mathrm{L})\end{array}$ & $\begin{array}{c}\text { Outlet Concentration } \\
(\mathrm{mg} / \mathrm{L})\end{array}$ \\
\hline TSS & 119 & 17 \\
\hline BOD $_{5}$ & 357 & 202 \\
\hline TP & 25 & 4 \\
\hline Nitrate & 0.2 & 0.1 \\
\hline TKN & 1596 & 48 \\
\hline
\end{tabular}

Thurston-Enriquez ef al. (2004) monitored a constructed wetland treating milkhouse washwater and cattle wastewater in Nebraska, USA. The treatment system consisted of a concrete manure storage system with a debris basin, a single FWS wetland cell with a depth of $0.3 \mathrm{~m}$ and distribution onto a crop field. The welland cell was designed to be planted with emergent vegetation after the completion of the study. The inlet and outlet nutrient concentrations from the study are presented in Table 2.6. The 
concentrations of all of the constituents demonstrated an increase through the wetland, which implies that there were issues associated with the operation that needed to be addressed. Table 2.6 demonstrates the variability in concentration measurements that was also noted in the study conducted by Pries and McGarry (2002). This variability in wastewater concentrations creates high standard deviations in the data analysis.

Table 2.6 Inlet and Outlet Constituent Concentrations from Thurston-Enriquez et al. (2004)

\begin{tabular}{|c|c|c|}
\hline Constituent & $\begin{array}{c}\text { Inlet Concentration Range } \\
(\mathrm{mg} / \mathrm{L})\end{array}$ & $\begin{array}{c}\text { Outlet Concentration Range } \\
(\mathrm{mg} / \mathrm{L})\end{array}$ \\
\hline TP & $24-44$ & $21-52$ \\
\hline Ammonia & $0.1-68$ & $0.2-115$ \\
\hline Nitrate & $0.1-8$ & $0.2-42$ \\
\hline TKN & $104-223$ & $145-194$ \\
\hline
\end{tabular}

At Oregon State University, a study was performed on a constructed wetland treating the runoff from a feedlot and barn housing 160 cows (CH2M Hill and Payne, 1997). The constructed wetland consisted of six, $6 \mathrm{~m}$ wide. $27 \mathrm{~m}$ long. $0.3 \mathrm{~m}$ deep vegetated FWS wetland cells. The cells were vegetated with a mixture of cattails. bulrushes and grasses. The influent and effluent concentrations from the study are presented in Table 2.7. The results of this study demonstrated a good reduction of all constituents, where TP and ammonia concentration reductions were the least efficient of the entire system.

Table 2.7 Inlet and Outlet Constituent Concentrations from the Oregon State University Study (CH2M Hill and Payne, 1997)

\begin{tabular}{|c|c|c|}
\hline Constituent & Inlet Concentrations $(\mathrm{mg} / \mathrm{L})$ & $\begin{array}{c}\text { Outlet Concentrations } \\
(\mathrm{mg} / \mathrm{L})\end{array}$ \\
\hline $\mathrm{TSS}$ & 542 & 142 \\
\hline $\mathrm{BOD}_{5}$ & 705 & 242 \\
\hline $\mathrm{TP}$ & 33 & 17 \\
\hline $\mathrm{Ammonia}$ & 126 & 65 \\
\hline
\end{tabular}




\subsection{CONSTRUCTED WETLANDS IN CANADA}

The main challenge to wetland treatment systems in Canada is the cold climate. In Canada, wetlands will freeze during a certain period of the year, whereas in more southern locations, this may not be a limiting consideration. As temperature decreases, the efficiency of the system is also decreases. For instance, at $6^{\circ} \mathrm{C}$, the removal of $\mathrm{BOD}_{5}$ from $240 \mathrm{mg} / \mathrm{L}$ to $40 \mathrm{mg} / \mathrm{L}$ requires a retention time which is double that which would be required for the same conversion at $20^{\circ} \mathrm{C}$ (Revitt et al., 2001).

If the water within the wetland were allowed to freeze, then the treatment would stop altogether. For the wetland to remain operational during the colder months, the surface of the wetland can be allowed to freeze. The water level of the wetland can then be lowered such that a dead air space will be achieved between the ice and the water level. Insulation can then be placed around the wetland, which will allow the temperature to remain at an acceptable level for treatment to continue. The presence of an ice cap could lead to the development of anaerobic conditions within the system, which would change the type of treatment being performed. A mechanical aerator can be employed to maintain aerobic conditions within the system. Lower temperatures would also lead to a decrease in the treatment potential of the system, thus, requiring a larger area to continue to provide sufficient wastewater treatment. Sub-surface flow wetlands must be well insulated to maintain the system at the design temperature (Herskowitz, 1986).

This insulation and aeration solution creates a requirement for the monitoring of the wetland through the cold weather in order to maintain optimal conditions. Another option would be to store the water during the non-growing season, and to treat the water when the seasons change. Storing the water reduces the costs of wetland operation since 
there is no need for effluent monitoring through the period while the wetland is frozen, and the initial water entering the wetland can be controlled to optimize growth and treatment efficiency. Storage of wastewater requires a basin large enough to accommodate all of the wastewater that will be produced while the system is not functioning, which increases the land requirement, as well as construction costs.

\subsection{TRACERS}

A tracer is a substance that is present in the water, the pollutant, or can be added to the water to determine flow properties. Many tracers are conservative substances that ease the determination of the properties that govern the water movement. Other tracers are non-conservative substances that have a known decay rate, which can make them as useful as the conservative substances.

\subsubsection{Methods of Tracer Studies}

The method used to perform a tracer study depends upon the reason for the study. If the purpose of the study is to determine the hydraulic residence time within the system, then a single sampling point can be placed at the outlet of the system to determine the time at which the tracer peak concentration occurs. If the test is employed to determine the flow characteristics, many points need to be placed throughout the system. Both testing methods involve a number of samples being taken at set time intervals. The simplest data collection method employs automatic samplers, which can be set up to collect multiple samples at desired time intervals.

In the case of determining the residence times, the sampling generally starts when the tracer is injected, and continues until a concentration peak is observed, and the tail of 
the peak is defined. This method of testing can identify short-circuiting and dead spaces within the system, as well as the actual flow times.

In situations where the test determines the flow properties of the system, samples must be taken at many sampling points, which would require many automatic samplers. This is an expensive endeavor, but enlarging the test area, which implies that the sampling can be done less frequently, can reduce the cost. The number of sample points would then increase, however, sampling less frequently implies that manual sampling could be done, as opposed to using expensive equipment.

There are two main tracer methods for flow determination. The first is to sample at various fixed points within the system, at fixed time intervals (fixed location method). The concentrations that are sampled at each interval are recorded and the size of the plume is interpolated. The second method is to measure the arrival time of the tracer or the evolution of the tracer at fixed reference points (VanderBrought and Vereecken, 2001).

The first method requires a large number of sampling points to adequately determine the dispersion of the tracer. This creates the need for a large area available for testing. If there is no previous dispersion data for the system, then the area of testing must allow for a large amount of dispersion as a safety factor to minimize the portion of the plume that might escape the testing procedure.

The second method requires monitoring of a single plane within the system for the arrival time of the tracer (flux method), where the time and the flux are the important factors. This removes the large area requirement since the monitoring is associated with one plane, and the longitudinal dispersion can be categorized with the flux. The 
concentrations are measured at the single plane rather than over an entire system. For this reason, the arrival time analysis of the tracer is considered to be a more efficient method of testing in ground water systems (Vanderbourght and Vereecken, 2001).

Each method of monitoring has its advantages. The sampling of concentrations at defined time intervals is useful for determining flow pathways through a water system that is plagued with obstacles. This method is useful for wetlands that are vegetated with areas of varying density, or soils with boulders or varying components. The flux method is able to provide an overall picture of the movement of the water, however, it will not demonstrate the flow pathways. For this reason the flux method is of no use when determining the physical flow paths of the water.

The fixed location method of transport determination requires more space than the flux method. The fixed location method will demonstrate the flow within the system. while the flux method will give overall flow properties for the system. Each monitoring method is useful for different purposes.

When setting up a tracer study, there are several details of the study that must be taken into account: the method of tracer concentration determination; the amount of tracer; the density of the tracer; and the methodology of the study.

\subsubsection{Amount of Tracer}

The amount of tracer that is injected into the system is very important. There must be enough tracer such that the concentration will be detectable at the sample points, and since chemicals are expensive, the smaller the quantity of tracer used, the least costly. There are many different methods used to determine the quantity of tracer to be added. 
The two main factors involved in assessing the quantity of tracer to add include: firstly, the detection limit of the testing equipment; and, secondly, the quantity of tracer to be added must be large enough such that if the tracer were to be dissolved evenly throughout the system, the concentration would be above the detection limit.

The background concentrations of the compounds that make up the tracer should be measured throughout the system. This will give a measure of the tracer substance that is already in the system. The amount of tracer that is added to the system should be in large enough quantity such that if the tracer were fully dissolved within the whole system, the concentration would be notably greater ( 5 times) than that of the background.

Once the detection limits of the equipment and the background concentrations have been established, the amount of tracer that is to be added can be computed. The amount of tracer to be added will be the smallest amount of tracer that will comply with both criteria discussed above.

\subsubsection{Concentration of Tracer}

The proper amount of tracer to add is key for the determination of concentrations during sampling. The density of the tracer is another important consideration and should, ideally, be similar to the density of the wastewater that the tracer is entering. Stream water will have a lower density, while a more concentrated wastewater stream will have a greater density. If the tracer is too dense, then it will sink and will not flow with the water until it has mixed with the water to an equivalent density (Schmid et al., 2004; Chazarence et al., 2003). This would result in erroneous time calculations.

Once the density of the water from the system has been established, the proper concentration of tracer can be determined. Adding the proper amount of tracer to distilled 
water will produce the mass of a $1 \mathrm{~L}$ sample of water from the system. Computing the mass of tracer that is added will give the maximum concentration of tracer that will have the same density as the water from the system. This maximum concentration will be the concentration used to input the tracer into the system. Some studies have dissolved salt tracers to match the total dissolved solid concentrations of the wastewaters instead of matching the density of the wastewater (Rash and Leihr, 1999)

\subsubsection{Determination of Tracer}

The analytical techniques employed to determine the concentration of tracer at sample points are very important. Some of the devices employed for determining concentrations of tracer can be interfered with by other chemicals within the sample. This is most evident in ion selective electrodes, and colourimetric analyses. The voltage reading is based on the ability for the ions to conduct electricity within the solution.

If the technique that is being used is photometric, or colourimetric (opacity or colour based), the clarity of the sample solution is important. A murky sample may result in erroneous readings due to the pre-existing colour or the lack of clarity.

The degree of precision that is required is also important. If the tracer test is being used to determine the flow properties of the system, then high precision (experimental error $<0.1 \mathrm{mg} / \mathrm{L}$ ) is required to best determine the components of flow. If the study is used to determine the residence time in a system, then the precision requirements may be lowered. With lower precision, concentration peaks are still visible, but the concentration at the peaks need not be exact. 


\subsubsection{Dye and Chemical Tracers}

There are a number of different types of tracers that could be used in studies. The information that is required from each test, as well as the starting point, are the factors of the greatest importance. There are many lesser factors that are also involved in tracer selection.

The simplest of all tracers is the dye tracer. As its name suggests, the dye tracer is a coloured dye that is injected into the water and the concentration of the dye is measured as an intensity of colour at sampling points. The dyes can also be used to determine the interaction between the soil and the water. Chemical tracers such as bromide and sodium chloride can be used in the same manner as dye tracers and, therefore, they have been included in this section.

The dye tracer is best suited for surface waters. The larger the water system. the more dye will be required. Tests have been conducted on streams with dyes, but their use for rivers requires more dye and better evaluation techniques due to the large cross sections and greater mixing in a river.

Flowing surface water, interacts with the soil matrix along the banks and beds in a process called hyporheic exchange. Since dye tracers mix with the water and react to the environment in the same manner as water, they are very useful in the determination of the effects of hyporheic exchange within streams (Laenen and Bencala, 2001). This exchange results in an increased residence time of the dye within the stream. Thus, the determination of transport within the system has an added retardation factor (Lin et al., 2003). 
Some of the dye tracers, such as Rhodamine WT, react with light and degrade in a process called photodegradation (Leanen and Bencala, 2001). This has advantages and disadvantages. A dye tracer that remains in the water system will degrade with time with light and will have less chance of causing alarm when found in the discharge water system since there will be no colour remaining in the water. The rate of photodegradation can be estimated with respect to the given environmental conditions during the testing period, and this degradation is then added to the equation for transport within the stream.

\subsubsection{Uses of Tracers}

Tracers can be used to determine characteristics of water through any flow situation. The flows in environmental systems that are most frequently monitored with tracer studies are surface and ground water flow. Both types of flows are governed by the same principles. In simplest terms, the water will flow from the higher energy areas to the lower energy areas. The distribution of the solids (tracers. contaminants, etc...) is also governed by the same basic concepts.

With any flow of water where there is turbulence, the distribution and spreading of a tracer plume is governed by three basic concepts: advection. diffusion and dispersion (Bedient et al., 1994). The magnitude of the effect of these three factors depends upon the method of tracer input. The amount of time required for tracer injection, the geometry of the tracer injection (point source, line source) and the position of the tracer injection are all important elements that require consideration. 


\subsubsection{Flow Within Free Water Surface Wetlands}

The primary distribution of the tracer within the open channel is generally via advection. Advection is the movement of the tracer along with the bulk flow of the wastewater. Therefore, if the movement of the tracer were based solely on advection, the equation for the motion of the tracer would be that of the movement of the water. This situation is not realistic as there are more stresses placed upon the system that influence the flow. The dispersion within the system, and any mixing from the movement of plant stalks must also be taken into consideration. There are some tracers that are nonconservative. The decay of these tracers can be accounted for with the addition of a decay term.

The next important factor in the tracer study is the type of injection. If the injection is an instantaneous injection. the distribution will be different than if the injection were constant.

Along with the determination of flow, tracers have other uses within a water system. In the instance of wetlands or other treatment systems, a tracer can help to determine the efficiency of the system. The tracer can be used to demonstrate any dead zones, which result in a shorter retention time calculation than expected. or areas in the system where the tracer collects, which result in a longer detention time than expected. The tracer can also be used to determine if there is any short-circuiting. If this were the case, the tracer would appear in sections earlier than anticipated. 


\subsubsection{Previous Studies}

There have been many studies performed with tracers. Some of the studies that were reviewed have dealt with dye tracers, and others with salt tracers. The studies had different purposes and were performed on different types of systems.

Kadlec (1994) used a lithium chloride tracer to determine the best type of model to use to describe flow in a wetland. Three models were analyzed: plug flow with dispersion, continuously mixed reactor, and a network model, which is a model that separates the wetland into finite sectors and monitors the effect of flow from each sector on the other sectors. Analysis of the effluent plume resulted in no clear advantage of any of these models. Therefore 26 points in the wetland were analyzed for tracer concentrations. The analysis of the interior points demonstrated that the network model best described the wetland of study.

Schmid et al. (2004) studied density stratification of salt tracers in a laboratory wetland simulation. They determined that the initial density of the salt tracer was important in deeper wetland systems, due to a retardation in tracer flow as the bulk of tracer sank before adequate mixing occurred, but in shallow systems $(>0.4 \mathrm{~m})$ the retardation effect was minimized.

Bowmer (1987) and Lin et al. (2003) monitored the flow of Rhodamine WT, a dye tracer, in conjunction with a bromide tracer to determine the usefulness of Rhodamine WT as a tracer in wetlands. Both studies determined that the Rhodamine WT is acceptable in low hydraulic retention time systems ( $<5$ days). Lin et al. (2003) also examined the sorption rate, photodegradation rate, and desorption rate of the Rhodamine 
WT to better explain the results of the studies which yielded $85 \%$ capture of bromide tracer, but only $59 \%$ capture of Rhodamine WT.

Simi and Mitchell (1999) used Rhodamine WT as a tracer to characterize the dead zones within a constructed wetland. Tracer tests were performed on two cells of the wetland, resulting in a capture of $82 \%$ and $79 \%$ of the original tracer mass. After analysis of the retention time of the tracers, it was determined that the volume of the wetland that the tracer flow occupied was $2800 \mathrm{~m}^{3}$, while the design volume was $3900 \mathrm{~m}^{3}$, therefore $30 \%$ of the wetland cell was concluded to be a dead zone. 


\section{CHAPTER 3 METHODOLOGY}

\subsection{SITE DESCRIPTION}

The constructed wetland used in this study was constructed on the Dignard dairy farm in 1994 and was designed to treat the wastewater from a herd of 150 livestock units. The dairy operation produces three types of wastewaters: washwater from the cleaning of milkhouse equipment, stormwater runoff from the cattle exercise yard and liquid runoff from the solid manure pile. Prior to the construction of the wetland, the liquid manure runoff and the milkhouse washwater were stored in a lagoon and periodically spread onto cropland, while the runoff from the exercise yard was not collected. The farmer was in search of a method or technology of treating the liquid wastewater which did not require application on to cropland. A schematic of the wetland is presented in Figure 3.1. Aerial photographs of the wetland system from 1996 and 2003 can be found in Appendix A.

Since the start of operation in 1996, the wetland has been fed by three different sources: stormwater runoff from an exercise yard, milkhouse washwater and runoff from a solid manure pile. The solid manure is stacked on a concrete slab with the use of an air piston. Runoff from the slab is collected in an anaerobic lagoon where it is mixed with the washwater from the milkhouse. The effluent from the lagoon is pumped at a rate of $11 \mathrm{~m}^{3} /$ day to a facultative pond. In the facultative pond. the lagoon effluent is mixed with the stormwater runoff from the exercise yard. 


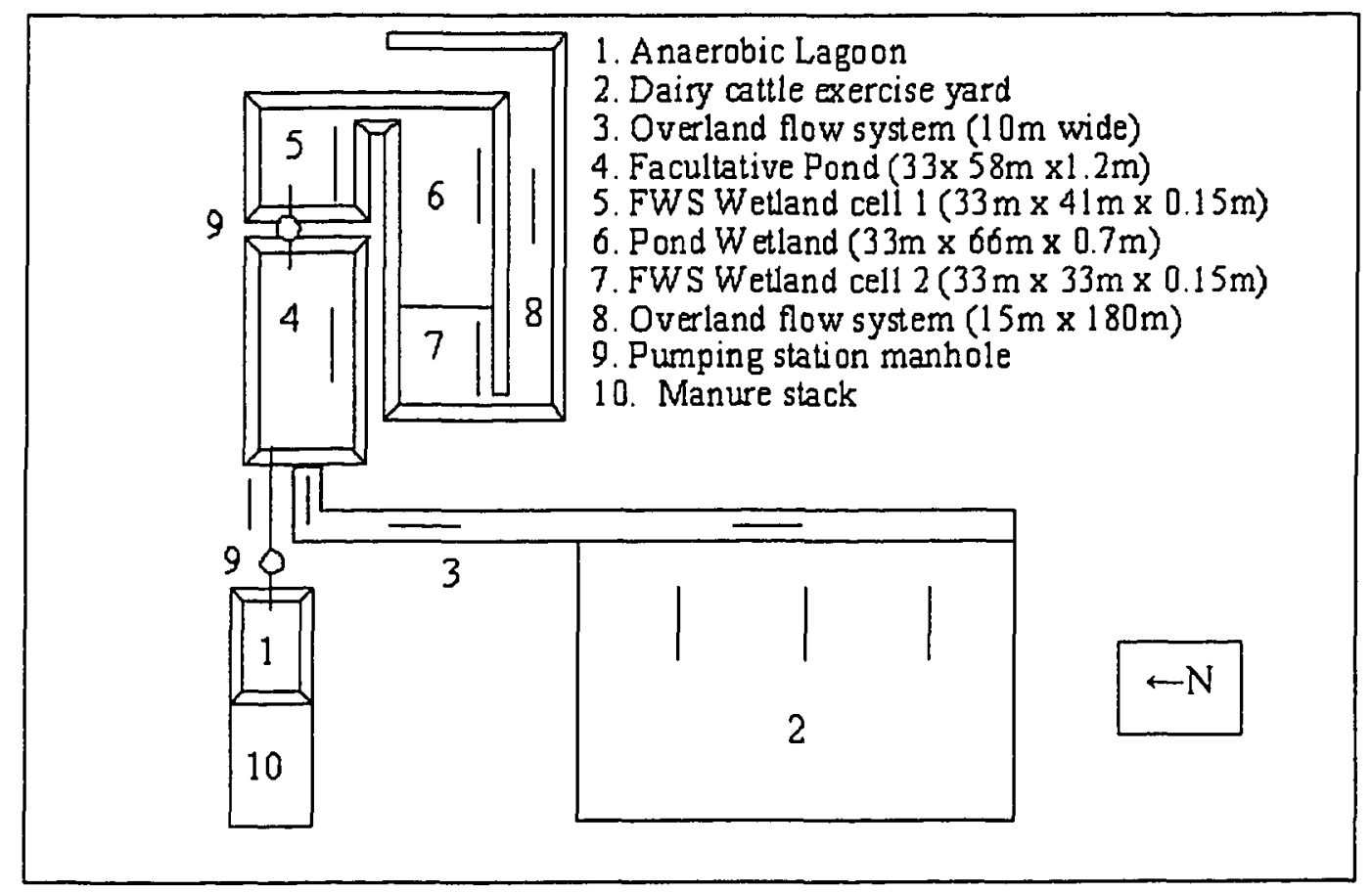

Figure 3.I Dignard Constructed Wetland System

Throughout the two-year study, between May and November, the effluent from the facultative pond was pumped at a rate of $21.9 \mathrm{~m}^{3} /$ day to the first vegetated wetland cell (FWS \#1: $41 \mathrm{~m}$ length, $33 \mathrm{~m}$ width and $0.3 \mathrm{~m}$ depth), using a four inch perforated PVC header pipe. The cell was densely vegetated with Typha latifolia (common cattails), and was designed to have a detention time of 20 days. The depth of the wetland cell was controlled by a v-notch weir at the outlet. Sampling units were placed within the cell at nine different points to draw samples from the water column and the sediment zones, as illustrated in Figure 3.2. Sample points were selected such that the sample locations followed the anticipated main flow path of the system. The location of point 9 was used to assess if any of the flow would reach that particular area of the cell.

The sampling apparatus consisted of $0.48 \mathrm{~cm}$ inside diameter Tygon tubing to draw the water column samples. The inlet of each of the sample tubes was incased in a 20 L sieve, with $0.64 \mathrm{~cm}$ perforations. The sieve was installed to protect the sample tubes 
from being clogged with large fractions of plant matter present in the wastewater. Each of the sample points that removed pore water samples from the sediments were equipped with a porous ceramic cup system with a $300 \mathrm{ml}$ sample storage volume to remove liquid samples without disturbing the sediment zones. Images of the sampling apparatus as well as the protective sieve, installed, in the wetland can be found in Appendix A.

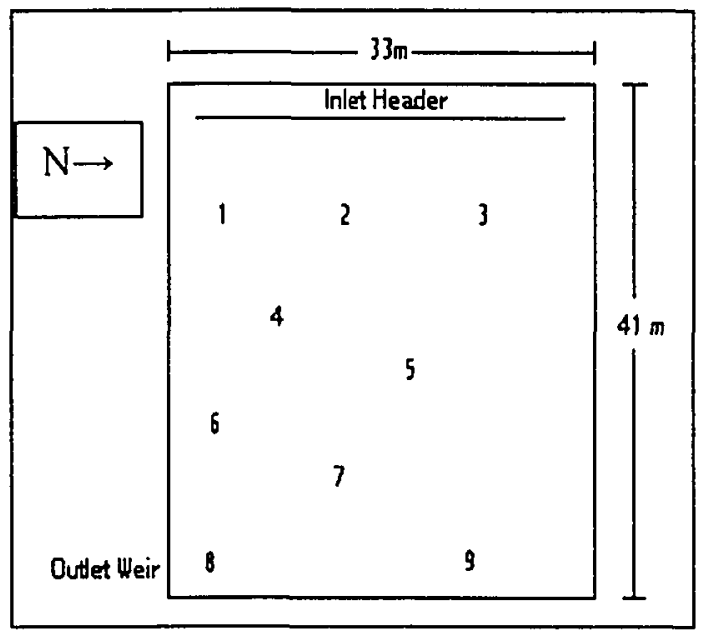

Figure 3.2 Sampling Locations in First Vegetated Wetland Cell (FWS \#I)

From FWS \#1, the wastewater flowed to the aerobic pond (Pond cell: $66 \mathrm{~m}$ length, $33 \mathrm{~m}$ width and $0.7 \mathrm{~m}$ depth). Vegetation was absent in Pond cell, which was designed to have a detention time of 88 days. Sampling apparati were placed at nine different points within the cell to sample from the water column (I-IX) and at six points in the sediment zone (I-III, VII-IX), as illustrated in Figure 3.3. The locations of the sampling points within the pond cell were selected to be evenly spaced along three planes within the cell. 


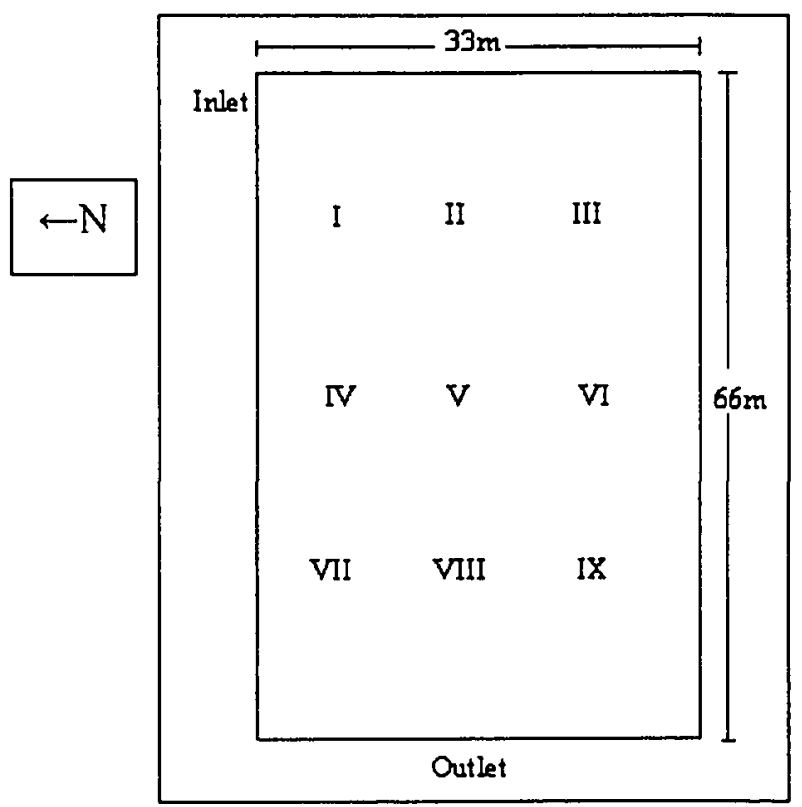

Figure 3.3 Sampling locations in Anoxic Pond Cell (Pond cell)

From Pond cell, the wastewater entered another densely vegetated cell (FWS \#2: $33 \mathrm{~m}$ length, $33 \mathrm{~m}$ width and $0.3 \mathrm{~m}$ depth). The vegetation in the cell was mainly comprised of Typha latifolia (common cattails). The height of wastewater in the cell was controlled by a v-notch weir at the outlet. Sampling apparati were placed at eight points within the cell to draw samples from the water column and the sediment zones, as illustrated in Figure 3.4. The sample point locations in FWS \#2 were selected in the same manner as for FWS \#1. Point $\mathrm{i}$ was selected to assess if any of the flow would reach that area of the cell. 


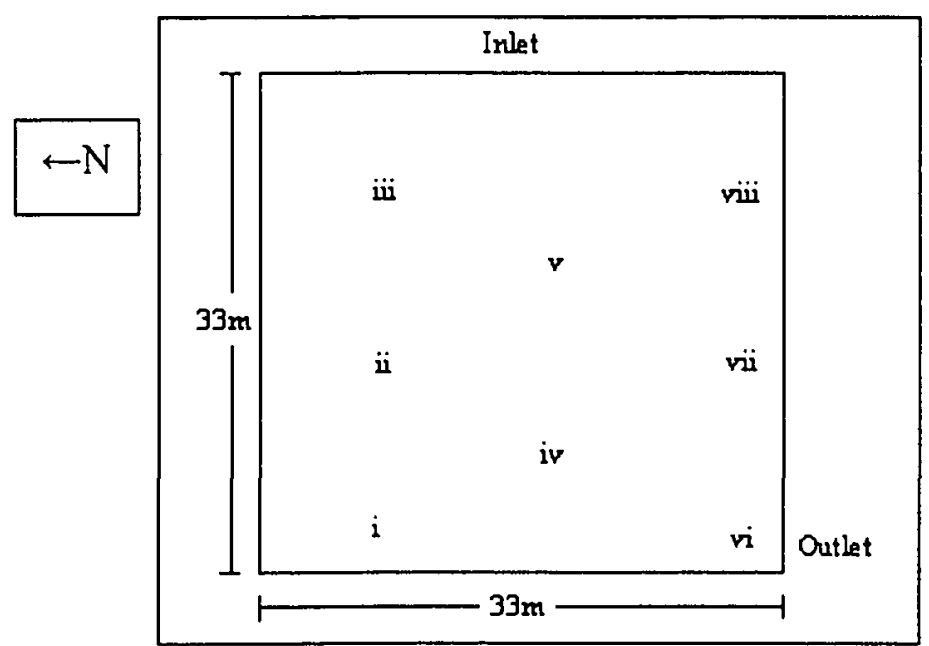

Figure 3.4 Sampling Locations in Second Vegetated Wetland Cell (FWS \#2)

\subsection{SAMPLING PROTOCOL}

During the first year of the study, the wetland was sampled based on a bi-weekly schedule starting May 21, 2003 and ending November 4, 2003. During the second year of the study, the wetland was also sampled based on a bi-weekly schedule, starting May 25. 2004 and ending August 4, 2004. The samples were collected on the Tuesday of each of the designated sampling weeks. In the event of rainfall, the sampling was delayed until twenty-four hours after the peak precipitation of the rainfall event.

During a sampling event, grab samples from the water column were taken at the influent and effluent of each wetland cell. At the sampling points within each wetland cell, grab samples were taken from the water column (2003 and 2004) and the pore water within the sediments (2003).

At every sampling point, two $300 \mathrm{ml}$ samples were drawn from the system. The in-situ analyses (temperature, DO, $\mathrm{pH}$ ) were performed from one of the samples, which was then stored in a cooler with icepacks unpreserved and transported for laboratory analysis of $\mathrm{BOD}_{5}$ and TSS concentrations. The other sample was acidified to a $\mathrm{pH}$ of 3 
with concentrated sulfuric acid, stored in a cooler with icepacks and transported for laboratory analysis of ammonia, nitrate, TKN and TP concentrations.

\subsubsection{Inlet and Outlet Samples}

Two grab samples were taken from each of the wetland cells. Samples were obtained using a sampling vial on an extendable pole. Samples were then analyzed for temperature, $\mathrm{pH}$ and $\mathrm{DO}$, then stored in a cooler with icepacks, preserved when required and transported for laboratory analysis of $\mathrm{BOD}_{5}$, TSS, TP, ammonia, nitrate and TKN concentrations.

\subsubsection{Water Column Samples}

Water column samples from within the cells of the wetland were drawn through the $0.48 \mathrm{~cm}$ Tygon tubes using a peristaltic pump. Samples were then analyzed for temperature, $\mathrm{pH}$ and $\mathrm{DO}$, then stored in a cooler with icepacks, preserved when required and transported for laboratory analysis of $\mathrm{BOD}_{5}$. TSS, TP, ammonia, nitrate and TKN concentrations.

\subsubsection{Sediment Samples}

Sampling of the sediment pore waters needed to be conducted in such a way that the sediments remained as undisturbed as possible. The apparati used for the sampling were not to alter the flow dynamics of the system, nor the processes at work within the sediments. Thus, placing a gravel sampling zone in the sediment, for example, would have created an area within the sediments with a high permeability which would have influenced the flow, as well as introduce a medium for new bacterial growth, thereby affecting the treatment processes within the system. 
For this reason, sediment zone samples were drawn with the use of porous cups. The cups were placed in the sediments at each of the sample locations. The porous cups allowed fluid to pass through their pores due to a pressure differential between the two sides of the porous surface ( 0.8 bars). This pressure was induced on the cups, by a hand vacuum pump, the day before the sampling was scheduled to take place, which allowed the apparatus to fill with a sample such that collection could be done quickly on the sampling day.

The porous cups that were used to collect samples acted as large filters, which implied that the sediments did not get disturbed nor removed during sampling. The liquid sample that was taken from the cups had a large fraction of the organic portion filtered out, therefore analyses for TSS and $\mathrm{BOD}_{5}$ were not performed. Only one $300 \mathrm{ml}$ sample was taken from the cups. These samples were analyzed for temperature, $\mathrm{pH}$, and $\mathrm{DO}$ concentrations. The samples were then stored in a cooler with icepacks, preserved with concentrated sulfuric acid and transported for laboratory analysis of ammonia, nitrate, TKN, and TP concentrations.

\subsection{TRACER STUDY}

A bromide tracer study was conducted on each of the two vegetated cells of the wetland (cells 1 and 3). This study was used to establish the distribution of wastewater flow through the wetland cells. The tracer was introduced into each cell at the same location as the expected wastewater input. During the first year of operation (2003), the inlet to FWS \#1 was a point source, due to a clogged inlet header. This allowed for the comparison of point source inlet and sheet flow inlet conditions, which was reestablished during the second year of the study (2004). 
During the first year of the study (2003), the two cells were dosed with $750-800 \mathrm{~L}$ of bromide tracer solution consisting of wastewater drawn from the pond cell and mixed with sodium bromide in a 1000 liter tank. The concentration of bromide in the tracer solution was approximately $5000 \mathrm{mg} / \mathrm{L}$. A second tracer test was conducted in the first wetland cell in the middle of the second sampling year (2004), which allowed for the comparison of the two flow dynamics consisting of a point inlet and header inlet. For the second test, the cell was dosed with $1000 \mathrm{~L}$ of bromide tracer solution with a concentration of $6000 \mathrm{mg} / \mathrm{L}$. The concentration of tracer was increased during the second year to achieve a faster sample analysis due to the higher bromide concentrations.

A daily composite sample was drawn at each of the sampling points of the cells. A peristaltic pump collected $30 \mathrm{ml}$ from each sampling point every 30 minutes (controlled by a Chrontrol XT digital timer) for the duration of each test (19-26 days). These samples were analyzed for bromide concentration with the use of a model $96-35$ Orion bromide electrode, to determine the tracer movement within each of the cells.

\subsection{ANALYTICAL PROCEDURES}

\subsubsection{Total Suspended Solids (TSS)}

The total suspended solids were analyzed in the laboratory using standard method 2540 D. "Total Suspended Solids Dried at $103-105^{\circ} \mathrm{C}$ (APHA, 1998). Samples were stored, unpreserved at $4 \pm 1^{\circ} \mathrm{C}$. The analysis was conducted within 48 hours of collection of sample. 


\subsubsection{Total Phosphorous (TP)}

The total phosphorous concentrations of the samples were analyzed in the laboratory using standard method 4500-P (APHA, 1998). The "persulfate digestion method" was used to digest the form of phosphorous within each of the samples to orthophosphates, which were then analyzed using the "Ascorbic Acid Method". Samples were stored, preserved with sulfuric acid to a $\mathrm{pH}$ of $<3$, at $4 \pm 1^{\circ} \mathrm{C}$. The analysis was performed within 28 days of sample collection.

\subsubsection{Ammonia}

The ammonia concentrations of the samples were analyzed in the laboratory using standard method 4500- $\mathrm{NH}_{3} \mathrm{D}$ "Ammonia-Selective Electrode Method" (APHA, 1998), with a model 95-12 Orion ammonia electrode. Samples were stored, preserved with sulfuric acid to a ph of $<3$, at $4 \pm 1^{\circ} \mathrm{C}$. Analysis was done within 28 days of collection of sample.

\subsubsection{Nitrates}

The nitrate concentrations of the samples were analyzed in the laboratory using standard method 4500- $\mathrm{NO}_{3}{ }^{\circ}$ D. "Nitrate Electrode Method" (APHA, 1998), and a model 9307 Orion nitrate electrode. Samples were stored. preserved with sulfuric acid to a $\mathrm{pH}$ of $<3$, at $4 \pm 1{ }^{\circ} \mathrm{C}$. The analysis was conducted within 28 days of sample collection.

\subsubsection{Total Kjeldahl Nitrogen (TKN)}

The TKN concentrations of the samples were analyzed in the laboratory using standard method 4500-N org B. "Macro-Kjeldahl Method" (APHA, 1998). Samples were stored, preserved with sulfuric acid to a $\mathrm{pH}$ of $<3$, at $4 \pm 1^{\circ} \mathrm{C}$. The analysis was performed within 28 days of sample collection. 


\subsubsection{Biological Oxygen Demand $\left(B O D_{s}\right)$}

The $\mathrm{BOD}_{5}$ concentrations of the samples were analyzed in the laboratory using standard method 5210 B. "5-Day BOD Test" (APHA, 1998), and a model 97-08 Orion oxygen electrode. The analysis was conducted with three different dilutions of each sample. Samples were stored, unpreserved at $4 \pm 1^{\circ} \mathrm{C}$. The analysis was initiated within 48 hours of collection of sample.

\subsubsection{Bromide}

The bromide concentration of each of the samples was analyzed in the laboratory with the use of a model 96-35 Orion bromide electrode. To overcome the interference from the ionic species within the samples, the concentration of bromide within each sample was increased by $20 \mathrm{ppm}$ by adding $1 \mathrm{ml}$ of $1000 \mathrm{ppm}$ bromide solution to $50 \mathrm{ml}$ of sample. The addition of a known amount of bromide to the samples ensured that the ratio of bromide concentration to all of the interfering ion concentrations was higher than required for the probe to accurately determine bromide concentration. Samples were stored, unpreserved, at room temperature and were analyzed within 5 days of collection of sample.

\subsection{SEDIMENT MAPPING AND VEGETATION DENSITY MEASUREMENT}

At the beginning of the second year of study, the sediment height and vegetation density were measured in FWS \#1. The cell was separated into a grid with sections $1.25 \mathrm{~m}$ wide and $2.15 \mathrm{~m}$ wide. The height of sediments was measured using a meter stick at the center of each of the grid sections. The vegetation density was measured as the fraction of the grid section, out of 10 , that contained plant stalks. 


\section{CHAPTER 4 \\ RESULTS AND DISCUSSION}

\subsection{TRACER STUDIES}

\subsubsection{Overview}

For both of the vegetated cells, the inlet was designed to be a header (line source) along the length of the inlet plane, while the outlet was a point along the southern side of the effluent plane (Appendix A). A conceptual analysis of the flow (a hypothesis based on the inlet and outlet positioning) that would be expected within each of the cells, neglecting plant media, would indicate that the stream should generally flow directly from the inlet to the outlet (Figure 4.1). This would imply that the flow would only pass through half of the entire area of the cell. Dispersion and mixing would allow the flow pattern to expand slightly towards the no flow zones, but there would always be areas of the cell that would not be contacted by the flow, and hence the wastewater.
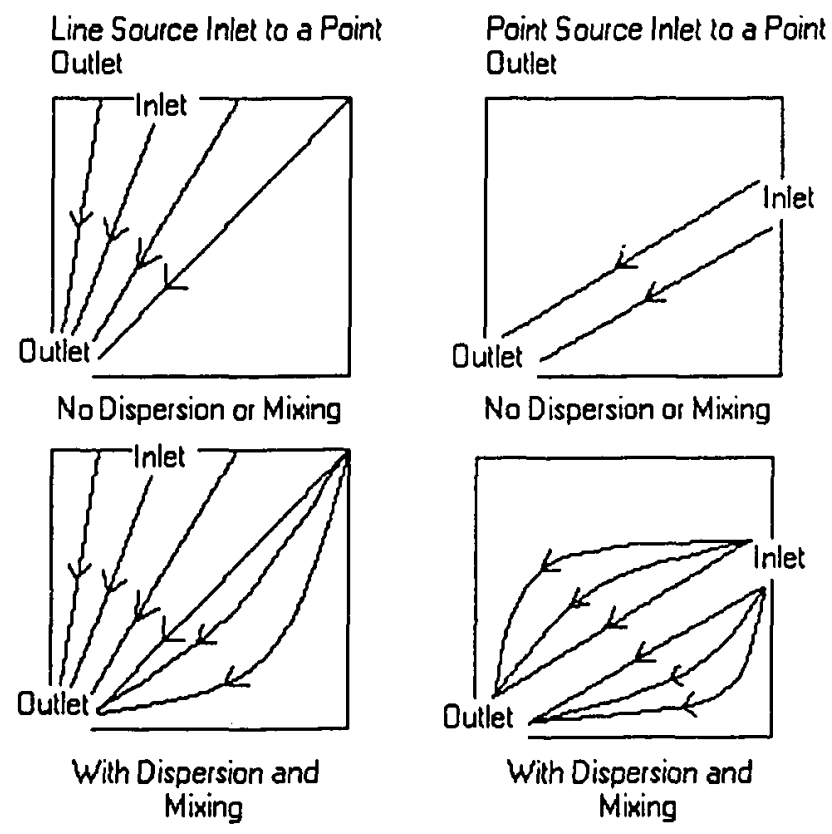

Figure 4.I Simplified Hydrologic Analysis of Expected Wetland Flow Patterns 
Changing the outlet from a point along one of the sides to a series of weirs along the outlet end of the cell would create a sheet flow dynamic over the entire cell. This would better distribute flow and would eliminate some of the dead zones within the cell. The elimination of these dead zones would mean that preferential flow pathways within the cell would become the primary inhibitor to the sheet flow dynamic that is ideal in wetland design.

The inlet flow that was observed in FWS \#1 differed from what was expected in the first year. This was due to the inlet header developing clogs, which resulted in the influent pipe being removed from the distribution header and placed along the north bank of the cell. The differences in inlet and outlet dynamics in FWS \#1 during the 2003 season are representative of a point source inlet with a point source outlet. The hydrologic analysis of the flow in FWS \#1 (Figure 4.1) would suggest that the flow would be concentrated in a direct path from the inlet to the outlet, but dispersion and mixing would draw the flow out transversely. The dispersion would not be sufficient to reach all of the areas of the cell, thus, the development of dead zones would be expected.

The simplified hydrologic assumption of flow pathways was consistent with the general constituent concentration distributions observed within the cells, as well as the sediment distribution. The validity of these assumptions was assessed with the use of a tracer study. The difference in flow dynamics in FWS \#1 between the two sampling seasons provided an opportunity to observe different dispersion patterns for the tracer, and hence the wastewater, throughout the cell. The raw data from the tracer studies can be found in Appendix C. 


\subsubsection{Tracer Distribution}

During each of the tracer studies, daily composite samples were drawn from each of the points within the wetland cell that was being analyzed. Outlet tracer concentrations from each of the cells are presented in Figure 4.2. The figure demonstrates the normalized concentrations $(\mathrm{C} / \mathrm{Co})$ of each of the three tracer studies. The hydraulic retention time of each cell was determined from the time required for the outlet tracer concentration to reach a maximum value. The retention times were determined to be 14 days for FWS \#1 in 2003 (85\% recovery of tracer), 13 days for FWS \#1 in 2004 (96\% recovery of tracer) and 11 days for FWS $\# 2$ in 2003 (79\% recovery of tracer).

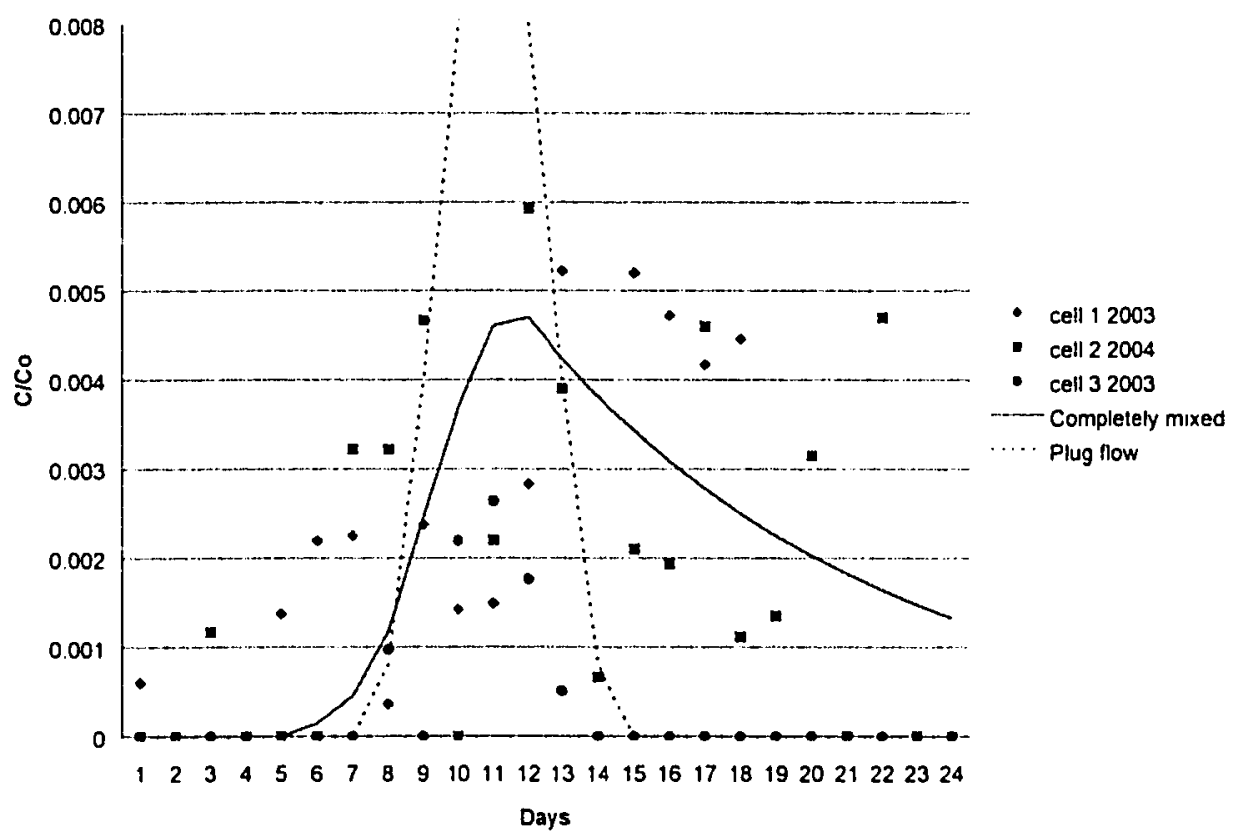

Figure +.2 C/Co Curves for the Three Tracer Tests

The general shape of each of the curves would indicate that flow within the cells could be best generalized as approaching a completely mixed flow condition. The curves for the two studies performed on FWS \#1 were found to have multiple local maxima and minima, which would not be expected in a completely mixed system. These maxima and 
minima would suggest that there were multiple flow pathways channeling the flow through the cell. Different retention times would be expected for each of the flow pathways and the superposition of these distinct flow paths resulted in the multiple peaks observed in Figure 4.2.

\subsubsection{First Vegetated Cell (FWS \#1)}

As previously mentioned, at the beginning of the first year of study, the inlet of the wetland was re-located from the header to a point along the northern bank due to a broken header pipe. The resulting area of flow was reduced from the expected design area. With the tracer concentrations measured from the daily composite samples, the area of flow was estimated, by krigging with the measured maximum tracer concentrations determined at each sample point, as shown in Figure 4.3. The darkest portion of the figure shows the main area of flow ( $>60 \%$ of tracer mass), while the middle area indicates locations where $40-60 \%$ of the tracer flow occurred, lighter area accounts for dispersion of the tracer $(20-40 \%$ of tracer flow). The zones where the tracer did not reach

are visible from the figure, as well. As can be seen, there was limited mixing upstream of the inlet. The actual flow pattern in this cell was relatively similar to the patterns hypothesized in figure 4.1 . 


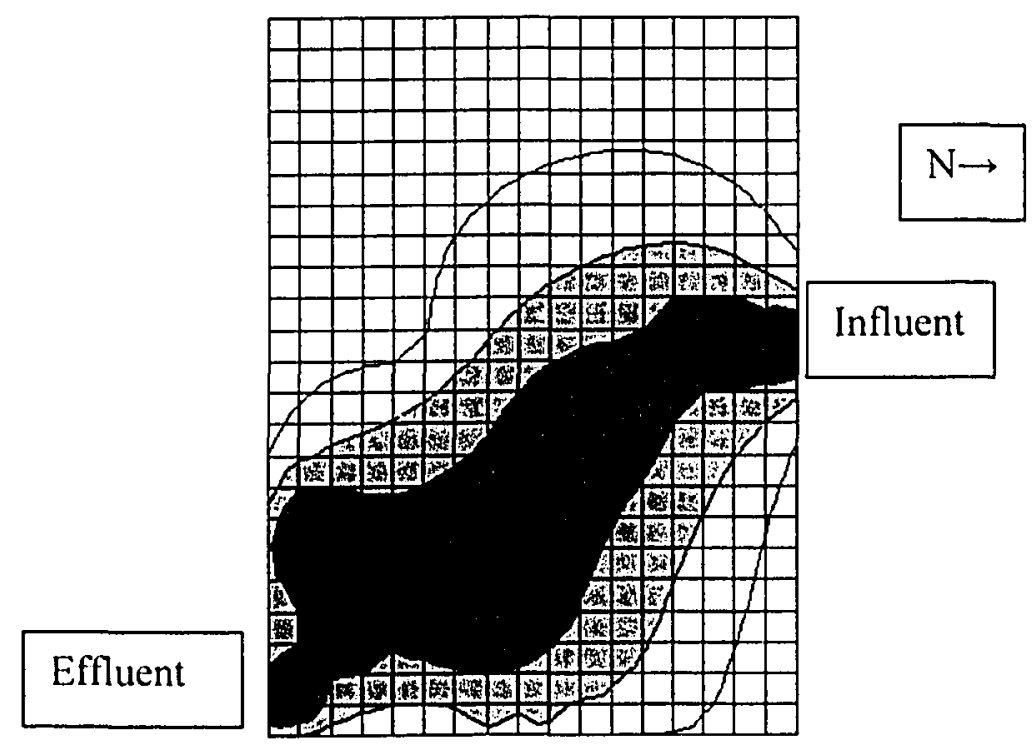

$60.00+$ प $40.00-60.00$ 020 $00-40.00$ $\square 0.00-2000$

Figure 4.3 Tracer Distribution in FWS \#I During the First Year of Study (2003)

Taking into account the residence time of the tracer $(T=14$ days $)$ and the average flow rate through the wetland $\left(Q_{\text {avg }}=20.9 \mathrm{~m}^{3} /\right.$ day $)$, which was calculated by averaging the pumped inlet flow rate $\left(21.9 \mathrm{~m}^{3} /\right.$ day $)$ and the outlet flow rate computed from the water balance presented in Appendix B (20.06 $\mathrm{m}^{3} /$ day). and using Equation 4-1, the cell volume receiving the flow was determined to be $306 \mathrm{~m}^{3}$. and the surface area of the flow (given a design depth of $0.3 \mathrm{~m}$ ) was calculated to be $1020 \mathrm{~m}^{2}$. The use of the design depth neglects any effect on the flow volume from the accumulation of sediments; this is a simplifying assumption since there was no analysis of the flow properties within the sediments performed on the wetland cell. From the tracer calculations, it would appear that $75 \%$ of the wetland volume was being used for treatment in the first year of the study (2003). However, the tracer distribution (Figure 4.3) did not support that this was actually the case. This was attributed to a lower than expected flow rate $\left(<20.9 \mathrm{~m}^{3} /\right.$ day $)$ during the tracer study, which could be the result of a damaged pump; or, since the pump was not 
controlled by the same timer as the sampling mechanisms, the operation of the pump may have stopped while the tracer study was still underway.

$$
\begin{gathered}
Q_{a \mathrm{~g} g} \times T=\forall \\
20.9 \mathrm{~m}^{3} / d a y^{\prime} \times 14 d a y=306 \mathrm{~m}^{3}
\end{gathered}
$$

During the second year of study (2004), the inlet was returned to a header configuration. This allowed for a second tracer study to monitor the differences in flow patterns between the two different inlet regimes. During the second year of the study (2004), the dosing of the wetland was controlled by the same timer that controlled the samplers. This ensured that the wetland was being dosed at a controlled rate.

The tracer distribution (Figure 4.4) of the second year (2004) demonstrated that the header was also not dosing the entire length of the wetland. indicating potential issues with the inlet header configuration. Another unexpected observation was that point 4 demonstrated a small capture $(30 \%)$ of the tracer, while 1 and 6 demonstrated a large capture of tracer. This would suggest that point 4 was in a low flow area, either blocked by sediment piles or extremely dense vegetation, and the tracer passed around the sampling point. Unfortunately, without a second sampling point between point 4 and the southern bank of the cell an absolute answer could not be formulated from the results. The pattern of flow distribution is similar to that which was discussed in Section 4.1.

Using the residence time determined by the tracer study (13 days), and the average flow rate through the cell $\left(20.9 \mathrm{~m}^{3} / \mathrm{day}\right)$, the volume of the cell employed under the new inlet flow regime was computed from the flow of tracer (using Equation 4-1) as $272 \mathrm{~m}^{3}$, which corresponds to $67 \%$ of the total volume of the cell. The retention time of the tracer in FWS \#1 was determined to be fairly similar in both years of the study, however the inlet pump was controlled in the second year of the study, thus, the retention 
time obtained in 2004 was most likely more accurate than the retention time obtained in 2003.

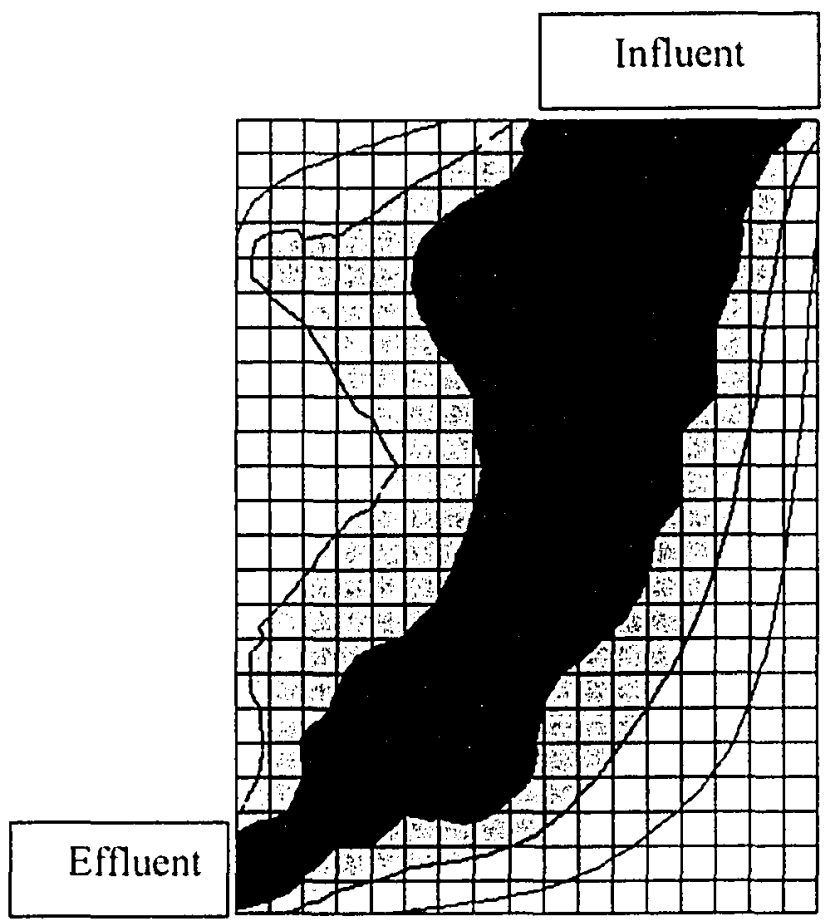

$\mathrm{N} \rightarrow$

Figure f.4 Tracer Distribution in FWS \#I During the Second Year of Studv (2004)

From the tracer study, the distribution of the tracer (Figure 4.4) demonstrated that the tracer contacted more than the $67 \%$ of the wetland surface area determined from the retention time calculations. The main flow path of the tracer covered most of the $67 \%$ of the area, while the dispersion of the tracer accounted for the increase in treatment area beyond the $67 \%$ that was computed. These calculations provided an estimate of the total treatment area. It would also be expected that the areas of treatment that received the lower concentrations of the tracer (from dispersion) would also generally receive lower concentrations of the wastewater constituents. 


\subsubsection{Second Vegetated Cell (FWS \#2)}

The tracer study was carried out on the third cell of the wetland in the first year of the study (2003). A second study had been planned for the second year, to verify that the flow through the cell did not change, however, the equipment failed as the test started, and time constraints did not allow for the test to be re-started. The inlet and outlet dynamics (header inlet and point outlet) of the cell were the identical for the two years, and it was surmised that the flow patterns would not have changed significantly. Similarities in the nutrient concentration distributions throughout the cell (Section 4.2) also supported the assumption that the flow through the cell was similar during both years of study. The tracer distribution was similar to what is hypothesized in figure 4.1.

The tracer retention time in the cell was determined to be 11 days. From the retention time of the tracer within the cell, the volume of the cell that the tracer contacted was computed (using equation 4-1) to be $424 \mathrm{~m}^{3}$ ( $75 \%$ of design cell volume). The tracer distribution demonstrated that the main flow of the tracer was directly towards the outlet. with slight dispersion towards no flow portions of the cell (Figure 4.5). 


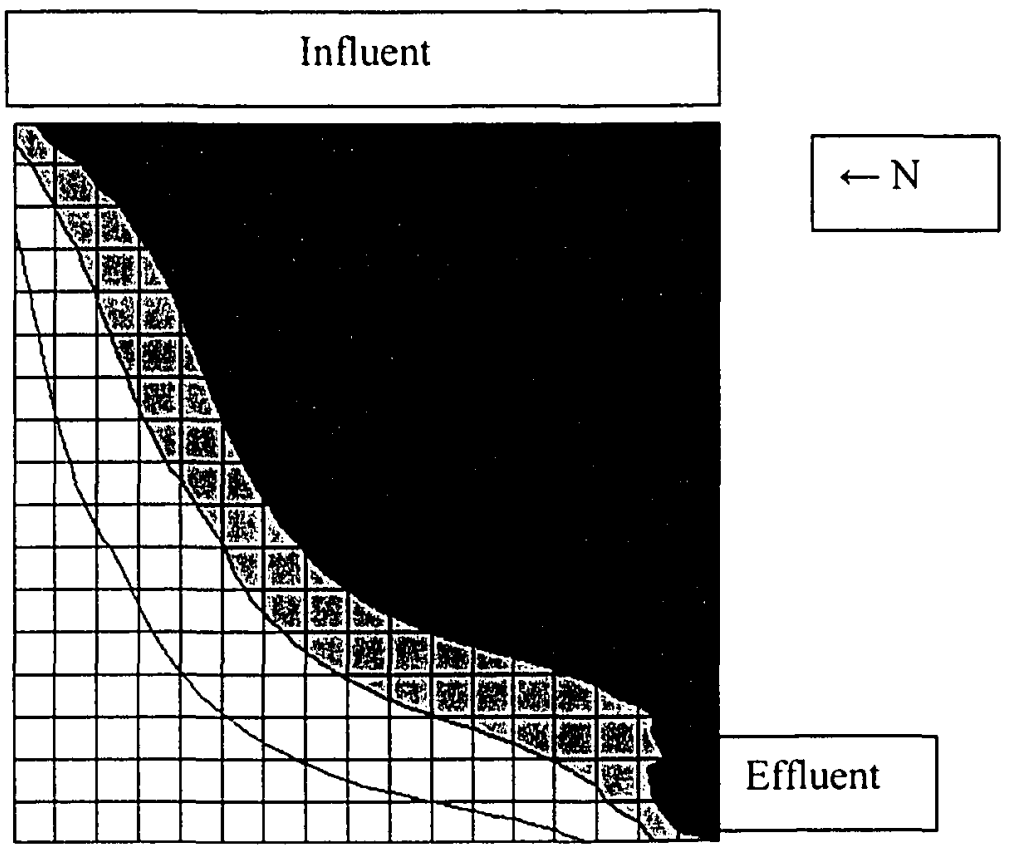

Figure 4.5 Tracer Distribution in FWS \#2 During the First year of Study (2003)

Monitoring of the tracer concentration profiles within the wetland indicated that there were preferential flow pathways throughout the two vegetated cells. There were sampling points within the wetland cells where lower concentrations were recorded, but these points were in locations that would indicate there was minimal flow to these points (Figure 4.1). This would have likely been the cause of the low concentrations, rather than high treatment efficiency.

\subsection{REMOVAL OF CONSTITUENTS}

The design of a wetland treatment system depends upon the strength of the wastewater stream that is to be treated. The higher the constituent concentrations within the wastewater stream, the larger the wetland area required to remove the constituents from the wastewater. To maintain the wetland design area as small as possible, the wastewater should receive treatment before it enters the first marsh cell of the wetland. The marsh-pond-marsh cells that comprise the actual wetland serve mainly as a polishing 
stage. There are many methods of removing constituents from the wastewater before it enters a wetland system. In this study, the wastewater is treated in an anaerobic lagoon, and then in a facultative pond before it enters the first wetland cell.

Figures illustrating the layout of the wetland along with the inlet and sampling locations can be found in Appendix A. The raw wastewater constituent concentration data from the two years of wetland monitoring can be found in Appendix B.

Constructed wetlands, being "natural" treatment systems that are exposed to environmental stresses daily result in variable data throughout the operating season. The annual patterns of concentrations are discusses in Section 3.1.1, and are demonstrated in the concentration values at other wetlands as well (Pries and McGarry, 2002; ThurstonEnriquez et al., 2004), which were presented in Section 2.2.7.

\subsubsection{Removal in the Lagoon and Facultative Pond}

At the Dignard constructed wetland, the lagoon is located at the base of the solid manure pile and collects the milkhouse washwater, as well as the runoff from the solid manure pile. Wastewater that is collected in this lagoon contains a high concentration of wastewater constituents. Since there is no dissolved oxygen in the lagoon wastewaters, anaerobic bacteria thrive. Anaerobic treatment of wastewater is an efficient method of quickly reducing the organic loads in wastewaters with high concentrations. The large surface area of the lagoon and the low velocity allow for the settling of solids from the wastewater. The settling of solids removes a portion of the organic matter, as well as phosphorous in the wastewater. The depth of the lagoon allows for anaerobic activity which further decreases organic matter as well as provides organic nitrogen and nitrate reduction. The $\mathrm{pH}$ of the wastewater in the lagoon ( $7.8 \pm 0.6$ in 2003 and $7.5 \pm 0.3$ in 2004) 
allows for volatilization of ammonia (Ferguson et al., 1984). If the nutrient concentrations within the lagoon were to decrease sufficiently, wind aeration could return the upper depths of the lagoon to an aerobic state, which would decrease the treatment efficiency of the lagoon with respect to the removal of organics.

To avoid aerobic conditions in the lagoon, the wastewater is pumped to a facultative pond. The lower nutrient loading of the pond allows wind aeration over the surface of the pond to keep the top portion of the pond under aerobic conditions while the deeper regions are anaerobic. This treatment is less effective in terms of removal of organic matter than the treatment in the lagoon, but the aerobic and anaerobic conditions of the pond are conducive to the removal of nitrogen in the wastewater.

Figures 4.6-4.11 show the average concentrations of nutrients entering the lagoon and the facultative pond and the removal efficiency of each wetland component. During 2003 and 2004, the lagoon demonstrated a large reduction (>75\%) of all of the nutrients that were monitored.

Evaluation of the effectiveness of the facultative pond was difficult due to unexpected circumstances. During the first year of the study, the sampling of the "FWS \#1 influent" (also the effluent from the facultative pond) from the wetland was not obtained from the point at which the wastewater entered the wetland. The wetland operator had moved the influent pipe from the inlet header because the header was not functioning properly. The inlet to the wetland was changed from a line input to a point input further down the side of the wetland cell (Appendix A). The resulting "inlet" samples were collected upstream of the actual inlet, in a stagnant area of the wetland cell. Therefore lower concentrations than the actual influent concentrations were measured. 
Without samples of the influent wastewater constituent concentrations, there can be no analysis of the facultative pond's treatment efficiency, or of the efficiency of the first wetland cell. In an attempt to remedy this discrepancy, an inlet concentration was estimated using the Kadlec and Knight (1996) model (Equation 2-5) and the constituent concentration data collected at sample point 5 as shown in Figure 3.2. The tracer study employed to analyze the flow in FWS \#1 during the first year of study was used to estimate the retention time to point 5 of FWS \#1, which was 5 days. Using Equation 2-5, the retention time at point 5 and the inlet flow from the pump $\left(20.9 \mathrm{~m}^{3} /\right.$ day $)$, the FWS \#1 influent concentrations were computed. For all of the wastewater constituents, the estimated FWS \#1 influent concentrations resulted in higher values than the facultative pond concentrations, signifying that some of the assumed model parameters were likely not applicable to this particular wetland, but without any further information, they were the best values available. Before the sampling began during the second year of the study, the header was repaired and the sampling proceeded as originally planned.

The TSS concentrations (Figure 4.6) show a similar trend in the removal of solids within the lagoon in both years of the study. Due to the assumptions made in the Kadlec and Knight model regarding the efficiency of settling, the assumed FWS \#1 influent TSS concentrations were too elevated $\left(\sim 10^{22}\right)$ to be representative and, and they were. therefore, not presented with the data. 


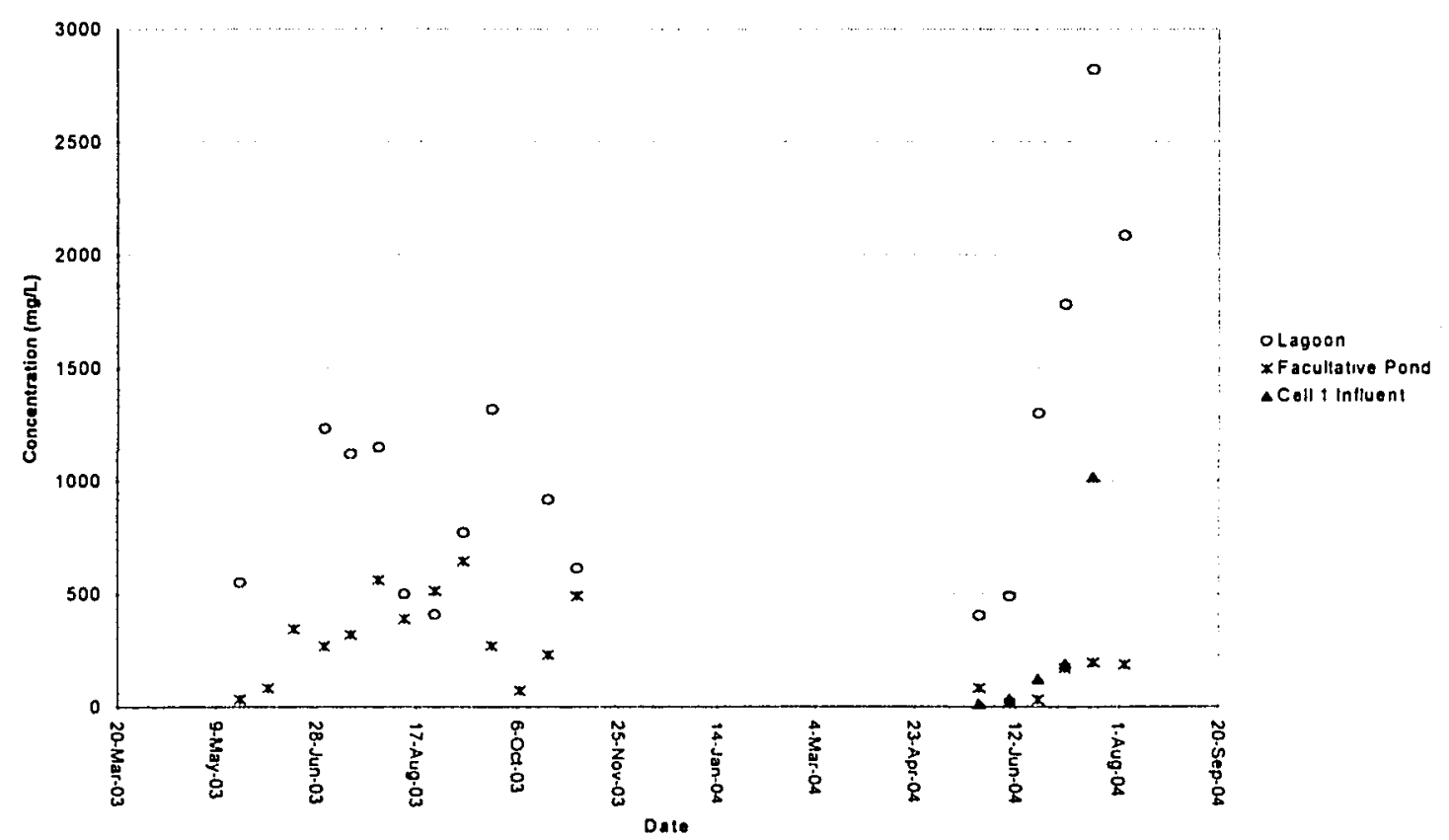

Figure 4.6 TSS Concentrations in Lagoon, Facultative Pond and FWS \#I Influent in both years of Study

The TP concentrations (Figure 4.7) demonstrated a reduction in concentration trend in the lagoon, but did not change significantly in the facultative pond. The removal of TP in both of these stages of treatment was associated with sedimentation (Kadlec and Knight, 1996). During both years of the study, the TP concentration decreased in the lagoon, but not in the facultative pond, as was the case with the TSS concentrations. which tended to agree with arguments presented by Kadlec and Knight (1996). 


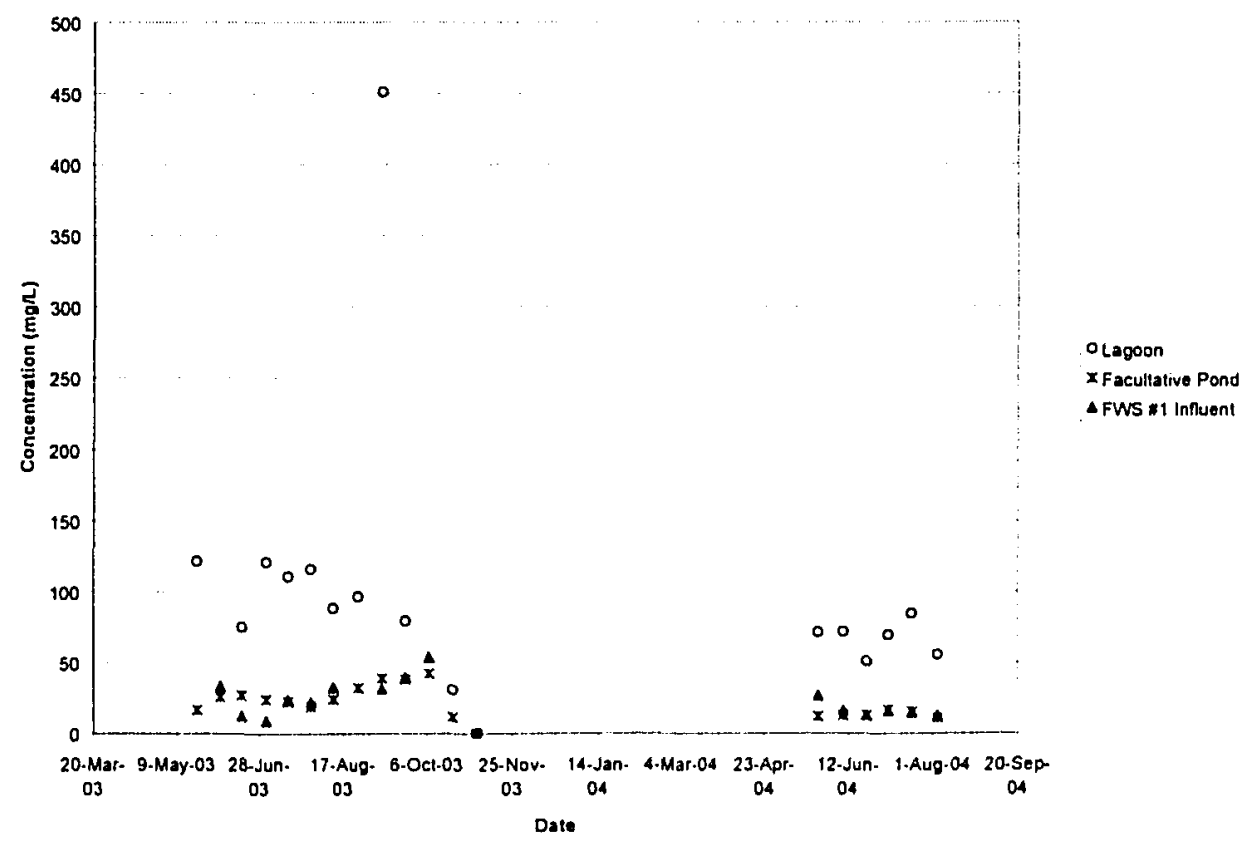

Figure 4.7 TP Concentrations in Lagoon, Facultative Pond and FWS \#1 Influent in both years: of Study

The ammonia concentration (Figure 4.8) demonstrated a concentration reduction trend within the lagoon, but there was no significant decrease in the concentrations in the facultative pond. The two primary methods for the reduction of ammonia concentration in wastewater are the oxidation to nitrate. which is a result of strict aerobic bacterial activity, and volatilization at $\mathrm{pH}$ greater than 7.5. The lagoon was anaerobic, thus. oxidation of ammonia did not occur, however, the $\mathrm{pH}$ was in the range required for volatilization. In the facultative pond, the $\mathrm{pH}$ was also within an acceptable range for volatilization $(8.3 \pm 0.4$ in 2003 and $8.2 \pm 0.3$ in 2004). but the concentrations did not indicate a reduction in concentration. This indicated that organic nitrogen was being reduced to ammonia at the same rate as the ammonia was volatilized. 


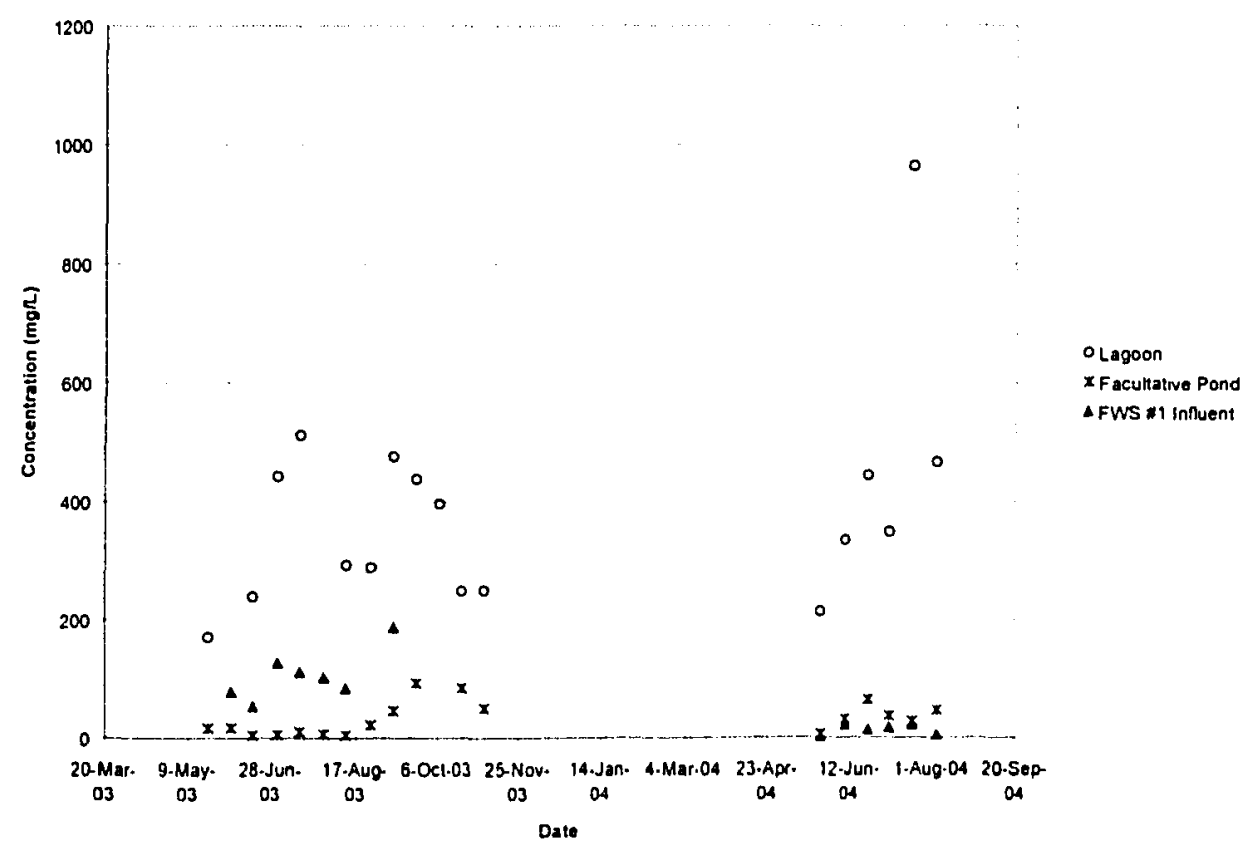

Figure 4.8 Ammonia Concentrations in Lagoon, Facultative Pond and FWS \#I Influent in both years of Study

The nitrate concentrations (Figure 4.9) demonstrated a reduction in concentration trend in the lagoon, but not in the facultative pond. The low nitrate concentrations were removed quickly in the lagoon. During the first year, the estimated FWS \#1 influent concentrations were higher than the facultative pond concentrations, but the concentrations from the second year indicated that there was little change in the nitrate concentration in the facultative pond, which would suggest that the computed concentration values overestimated the actual influent concentrations. The nitrate concentrations in the wastewater are already at background levels, and there is little to no change throughout the system. The assumption made within the design model is that there is a high influent nitrate concentration in the wastewater, and the wetland treatment will reduce that concentration, where as in this particular system, there is not an elevated nitrate concentration to begin with. 


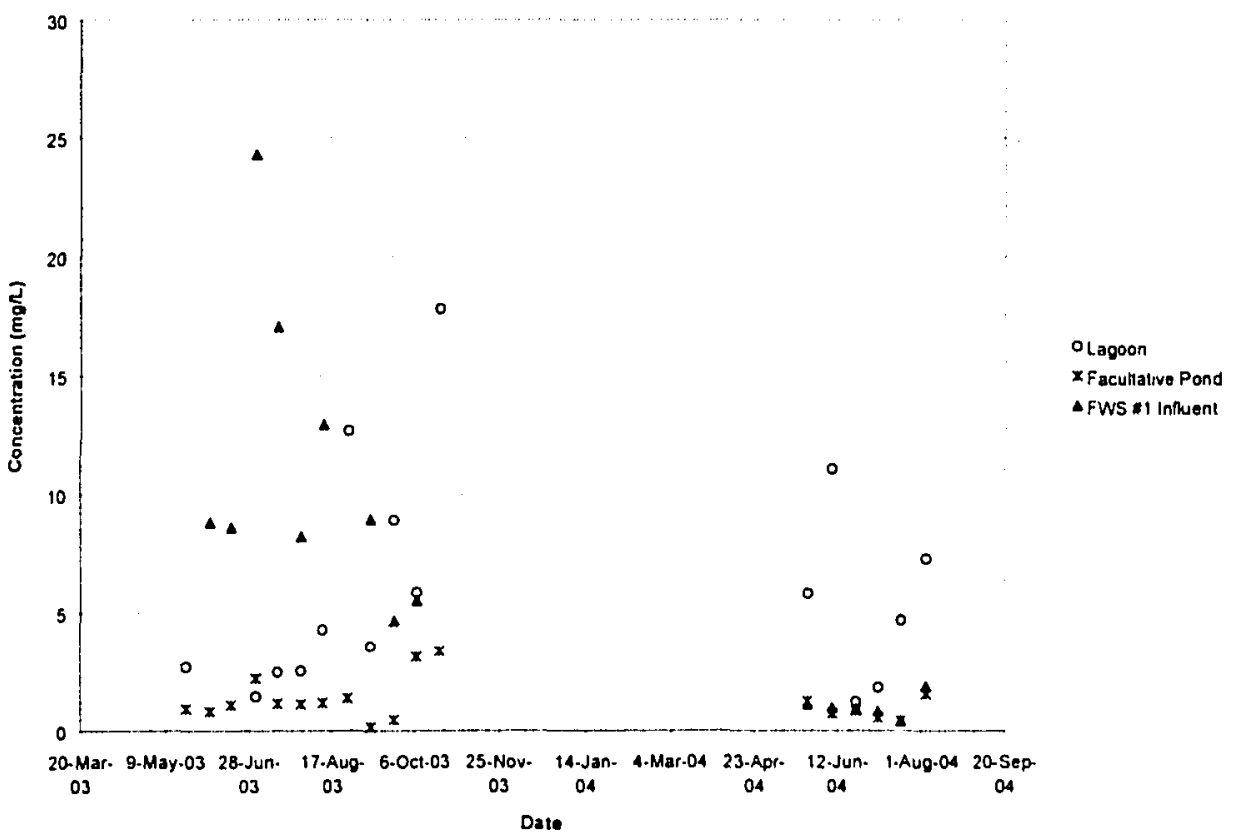

Figure 4. 9 Nitrate Concentrations in Lagoon. Facultative Pond and FWS \#I Influent in both years of Study

The TKN concentrations (Figure 4.10) also exhibited a reduction in concentration in the lagoon, but no difference was observed in the facultative pond. Without TKN analysis from the second year of study. there can be no assumptions made regarding the validity of the estimated FWS \#1 influent concentrations. 


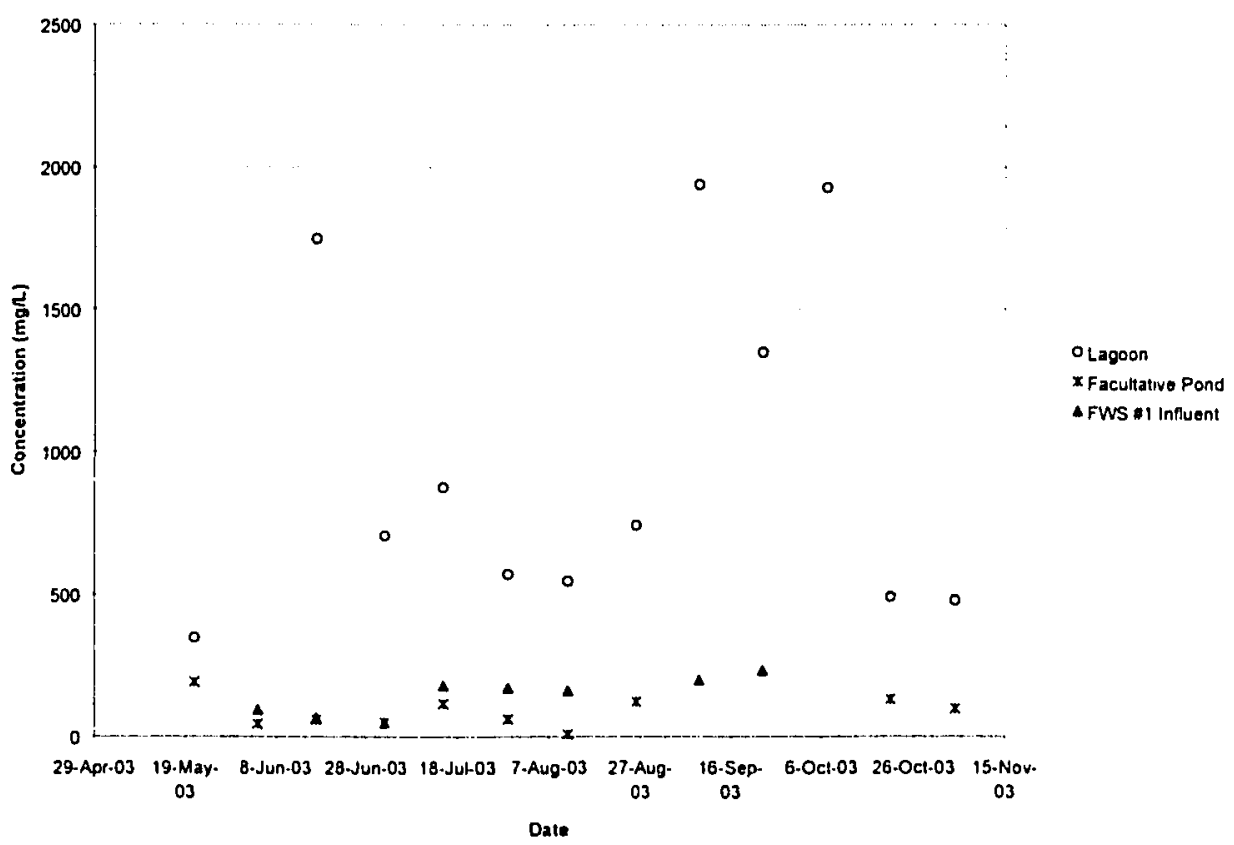

Figure 4.10 TKN Concentrations in Lagoon. Facultative Pond and FWS \#I Influent in both years of Study

The $\mathrm{BOD}_{\mathbf{s}}$ concentrations (Figure 4.11) showed a reduction in concentration in the lagoon as well, but no significant change in the facultative pond. The greater reduction of organics in the lagoon was expected based on the higher amount of anaerobic bacterial activity. The facultative pond was used by waterfowl as a resting place, therefore the waste from these birds increased the organic concentrations in the system, as did the significant amount of algae that was found in the pond. 


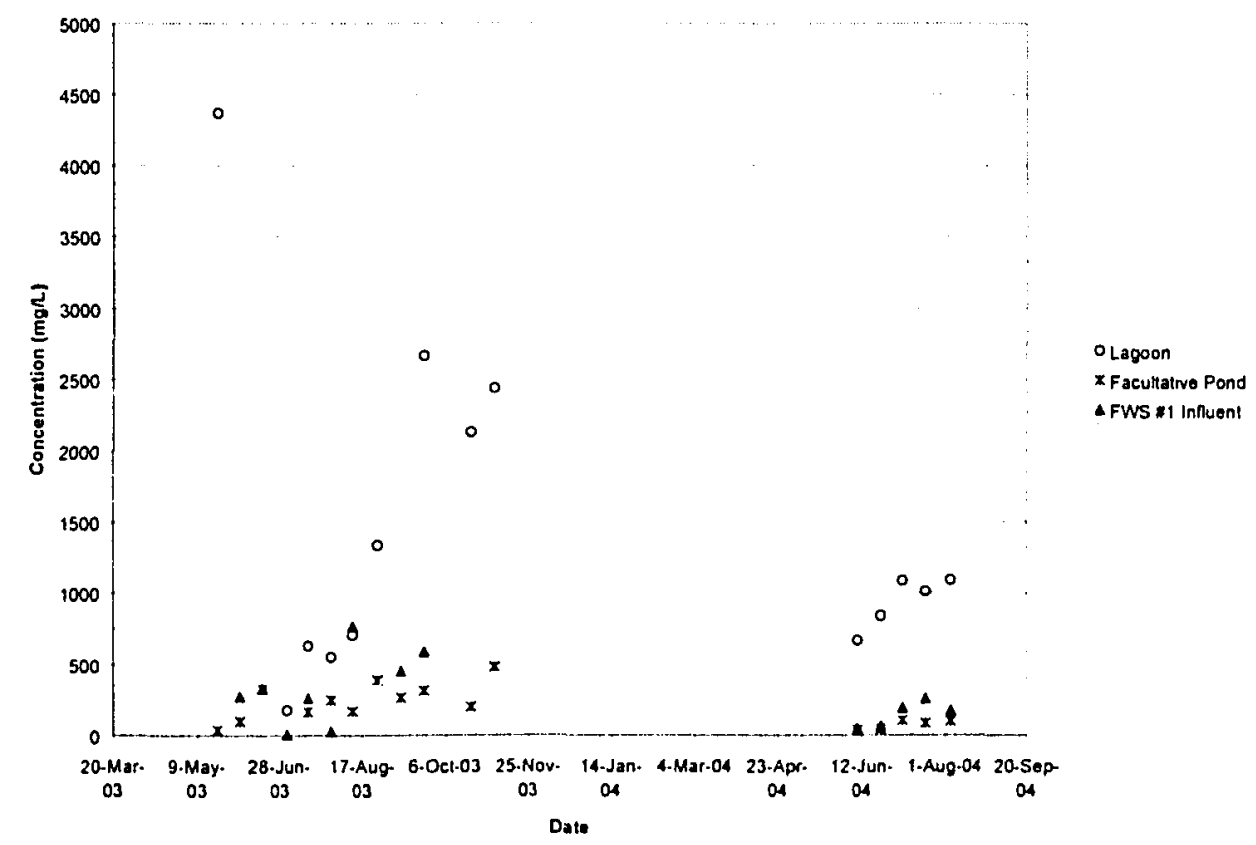

Figure t.11 BODs Concentrations in Lagoon, Facultative Pond and FWS \#I Influent in both years of Study

Lagoons and facultative ponds are efficient for the primary treatment of agricultural wastewater due to the long retention time associated with these units, which allows for the storage and treatment of wastewater. Wetlands offer the polishing of primary treatment effluent which is relatively rapid due to the large areas available for bacterial growth, as well as the availability of oxygen and the flora and fauna growing within the cells.

\subsubsection{Overall Removal within Wetland System}

The concentrations measured at each of the sites demonstrated the variability that was discussed in the above sections and is supported by the literature (Pries and McGarry, 2002; Thurston-Enriquez et al., 2004). Trends in average concentration distributions were verified with the use of ANOVA. Where these trends are significant with respect to ANOVA, the values of $f$ and $f_{\text {crit }}$ are presented. Where $f$ and $f_{\text {crit }}$ are not presented, the trend that is being discussed is the average concentration, but the 
variability of the data is not accounted for. The trend in variability of the concentrations is similar at all of the sampling points, therefore the change in average concentrations can be expected to be representative of what is actually happening in the wetland without accounting for the $95 \%$ confidence intervals (which are large due to the variability)

During the first year of the study (Table 4.1), wastewater constituent concentrations were extremely variable. This would be expected in constructed wetlands due to the environmental stresses placed on the systems. Rainfall events increase the flow through the cells and reduce the constituent concentrations by dilution, however. in the warmer summer season; the evapotranspiration of water from the system concentrates the wastewater and reduces the flow.

Table 4.I Wastewater Constituent Concentrations ( $\pm 95 \%$ CI) in each Wetland Cell (2003)

\begin{tabular}{|l|c|c|c|c|}
\hline Constituent & $\begin{array}{c}\text { FWS \#1 } \\
\text { influent }\end{array}$ & Pond influent & $\begin{array}{c}\text { FWS \#2 } \\
\text { influent }\end{array}$ & $\begin{array}{c}\text { FWS \#2 } \\
\text { effluent }\end{array}$ \\
\hline TSS & $\begin{array}{c}463.18 \\
( \pm 233.43)\end{array}$ & $\begin{array}{c}205.11 \\
( \pm 98.51)\end{array}$ & $\begin{array}{c}129.25 \\
( \pm 28.04)\end{array}$ & $\begin{array}{c}80.29 \\
( \pm 51.21)\end{array}$ \\
\hline TP & $\begin{array}{c}19.47 \\
( \pm 6.46)\end{array}$ & $\begin{array}{c}20.97 \\
( \pm 6.05)\end{array}$ & $\begin{array}{c}15.97 \\
( \pm 3.45)\end{array}$ & $\begin{array}{c}13.01 \\
( \pm 3.49)\end{array}$ \\
\hline Ammonia & $\begin{array}{c}106.75 \\
( \pm 32.03)\end{array}$ & $\begin{array}{c}13.58 \\
( \pm 6.89)\end{array}$ & $\begin{array}{c}13.59 \\
( \pm 7.25)\end{array}$ & $\begin{array}{c}5.28 \\
( \pm 3.27)\end{array}$ \\
\hline Nitrate & $\begin{array}{c}11.01 \\
( \pm 4.06)\end{array}$ & $\begin{array}{c}1.36 \\
( \pm 0.36)\end{array}$ & $\begin{array}{c}0.89 \\
( \pm 0.32)\end{array}$ & $\begin{array}{c}1.00 \\
( \pm 0.55)\end{array}$ \\
\hline TKN & 145.05 & 39.29 & 30.27 & 24.3 \\
& $( \pm 46.16)$ & $( \pm 7.55)$ & $( \pm 8.93)$ & $( \pm 7.06)$ \\
\hline BOD 5 & 341.23 & 79.44 & 64.57 & 50.99 \\
& $( \pm 181.19)$ & $( \pm 21.73)$ & $( \pm 2.58)$ & $( \pm 11.52)$ \\
\hline
\end{tabular}

The TSS concentrations were too variable at each of the sampling locations to make any general statements regarding the observations with respect to the removal of solids. The TP concentrations did not demonstrate any significant difference between any of the wetland cells, indicating that the reduction of TP had more than likely reached a 
steady state. Reduction of TP concentrations is achieved primarily by sorption onto sites within the sediment layers, but plant uptake does account for some removal as well (Kadlec and Knight, 1996). The plants use the phosphorous as a nutrient for growth, and as the plants die and decay, they release the phosphorous back into the wetland system. A reduction in TP concentration would typically signify that the rate of sorption and uptake of phosphorous is greater than the rate of release of phosphorous from decaying plants.

The concentration of ammonia demonstrated a significant reduction in the first cell of the wetland, but no significant change in the remainder of the cells. The pH measured in all of the wetland cells was between 7.3 and 7.5 , therefore. little volatilization of ammonia was expected. Figure 4.7 (Section 4.2.1) demonstrated that the assumption used to estimate the FWS \#1 influent concentrations in 2003 did not correlate well with the trends observed in 2004 with respect to ammonia concentrations for the FWS \#1 influent. The estimated concentrations for the FWS \#1 influent were higher than those observed in the facultative pond in 2003, but in 2004 the actual FWS \#1 influent concentrations were approximately the same as those of the facultative pond. Therefore, the estimated values for the FWS \#1 influent in 2003 were likely not indicative of actual influent concentrations and hence no assessment of FWS \#I treatment of ammonia could be confidently stated. There was no significant difference observed between the influent and effluent concentrations in any of the other cells, but there was a significant drop in ammonia concentration between the influent of pond and the effluent of FWS \#2 (from ANOVA: $\mathrm{f}=4.9>\mathrm{f}_{\text {crit }}=4.3$ ) indicating that there was ammonia removal within the wetland. 
Figure 4.8 demonstrates that the estimated FWS \#1 influent nitrogen concentrations did not show the same pattern, with respect to the facultative pond concentrations, as those observed in 2004. This indicates that the estimated concentrations cannot be assumed to be correct. All of the remaining nitrate concentrations were continuously low, demonstrating the ability for the wetland to reduce the nitrate at the same rate as it is formed (from the oxidation of ammonia)

The TKN concentrations only demonstrated a significant decrease in the first cell, but as with the other constituents, this was likely due to the overestimation of the influent constituent concentrations. Since there was no evaluation of TKN in the second year, there was nothing available to corroborate the estimation. Using the estimated influent concentration, the TKN percent removal through the entire wetland was calculated to be $83 \%$. This percent removal followed the increasing trend in TKN removal during wetland maturation. Samples from the 1997 sampling season, while the wetland was young, demonstrated a $67 \%$ removal, while samples from 2001 demonstrated a $71 \%$ removal (Crolla and Kinsley, 2002). This indicated that the estimation held with the increasing trend in TKN removal, but without a second year of concentration data, there could be no proof that the estimated concentration value was correct.

The $\mathrm{BOD}_{5}$ concentrations that were estimated for 2003 did not correlate well with the actual values from 2003. Therefore, the treatment in FWS \#1 could not be analyzed in the first year. There was no significant reduction of $\mathrm{BOD}_{5}$ observed in the remainder of the wetland.

Some large differences were seen between the concentration distributions of the first year of the study (Table 4.1), and those of the second year (Table 4.2). The influent 
to FWS \#1 was returned to the inlet header, such that the data from sampling point "FWS \#1 influent" was more accurate and pertinent to the study in the second year.

Table 4.2 Wastewater Constituent Concentrations ( $\pm 95 \% \mathrm{CI}$ ) in each Wetland Cell (200-4)

\begin{tabular}{|l|c|c|c|c|}
\hline Constituent & $\begin{array}{c}\text { FWS \#1 } \\
\text { influent }\end{array}$ & Pond influent & $\begin{array}{c}\text { FWS \#2 } \\
\text { influent }\end{array}$ & $\begin{array}{c}\text { FWS \#2 } \\
\text { effluent }\end{array}$ \\
\hline TSS & $\begin{array}{c}89.89 \\
( \pm 79.54)\end{array}$ & $\begin{array}{c}46.16 \\
( \pm 44.56)\end{array}$ & $\begin{array}{c}232.80 \\
( \pm 270.32)\end{array}$ & $\begin{array}{c}76.69 \\
( \pm 90.98)\end{array}$ \\
\hline TP & 16.74 & 11.38 & 11.43 & 11.02 \\
$( \pm 4.14)$ & $( \pm 1.35)$ & $( \pm 1.48)$ & $( \pm 2.83)$ \\
\hline Ammonia & 13.36 & 10.42 & 7.15 & 2.10 \\
& $( \pm 7.07)$ & $( \pm 5.58)$ & $( \pm 5.78)$ & $( \pm 2.43)$ \\
\hline Nitrate & 1.03 & 1.07 & 1.07 & 1.13 \\
& $( \pm 0.38)$ & $( \pm 0.39)$ & $( \pm 0.42)$ & $( \pm 0.43)$ \\
\hline BOD $_{5}$ & 149.32 & 50.75 & 51.10 & 53.63 \\
& $( \pm 77.96)$ & $( \pm 7.27)$ & $( \pm 40.25)$ & $( \pm 26.91)$ \\
\hline
\end{tabular}

The TSS concentrations within the cells were erratic, which was most likely due to the re-suspension of sediments, and caused by the shallow wastewater depth, during sampling.

The concentration of TP in the wetland decreased in the first cell (from ANOVA: $\mathrm{f}=5.82>\mathrm{f}_{\text {crit }}=4.96$ ), but remains constant throughout the remainder of the wetland. This appeared to indicate that the phosphorous removal within the wetland after the first cell had reached a steady state (rate of re-release equal to the rate of uptake). The plants will store the phosphorous and re-release it when they decompose. This coupled with the limited number of sorption sites in the soil and sediment. implies that the phosphorous treatment within the wetland will eventually reach a steady state; a time when the wetland plants will remove the phosphorous released from the decaying plants and not be able to remove any of the phosphorous entering with the wastewater stream. This is best demonstrated by comparing the efficiency of the system for the removal of phosphorous. In the sampling season of the year 1996, the wetland was able to remove an average of 
$75 \%$ of the TP from the influent of FWS \#1 to the effluent of FWS \#2. In 2000, that efficiency had decreased to an average removal of $49 \%$ (Crolla and Kinsley, 2002). This would suggest that the wetland system is nearing a steady state condition with respect to TP removal. The reduction in TP removal efficiency in a mature system would be expected due to the limited number of sorption sites at the commencement of wetland operation being decreased throughout the years of wetland operation. The reduction in TP removal may also be a result of sediments becoming too dense for the wastewater to reach the sorption sites in the soil at the bottom of the cells, or that bacteria have built-up a slime layer covering the sorption sites. Whether the sorption sites have been blocked or they have been used up is difficult to assess without further analysis, but the outcome of these two scenario are the same, the phosphorous in the wastewater is no longer being removed from the wastewater with the same degree of efficiency as in the initial years of wetland operation.

The removal of ammonia was observed over the entire wetland (from ANOVA: $f$ $=5.95>f_{\text {crit }}=5.32$ ), but the majority of the removal occurred in cells 2 and 3 . The nitrate concentrations remained low (as was observed with the 2003 data). The high variability of the $\mathrm{BOD}_{5}$ concentrations resulted in no observable reduction in concentration throughout the wetland cells.

The overall assessment of the wetland system based on the average concentrations at sampling points throughout the system did not result in marked changes in concentrations throughout the wetland. This was due to the variability of the data, as well as the maturity of the system. The variability of the average concentrations at the sampling points was large enough that ANOVA analysis resulted in very little significant 
difference between sampling points. The large variance in concentrations would not be an issue if there were large removals of constituents throughout the cells (as is expected in younger wetlands), but as the wetland has matured, and the removal efficiency of the cells has decreased, this variance has become more important

\subsubsection{Removal of Constituents in Wetland Cells}

Examining the overall removal within a wetland serves to understand the constituents that can be effectively treated. Separating the wetland further allows the analysis of each separate cell to note the advantages and disadvantages of different types of wetland cells and their configuration. To truly understand the nature of the wetland cells, analyses must be performed at various points throughout the wetland to better understand the effectiveness of all stages. This will lead to a better understanding of the sizing of cells such that land use may be minimized.

\subsubsection{First Vegetated Cell (FWS \#I)}

As was stated previously, the influent to FWS \#1 was moved from the header to a point source in the first year of the study (2003), but was returned to the header inlet configuration in the second year. The influent pipe was moved to a position along the north side of the first cell between sampling points 3 and 5 (Figure 3.2). This change in input created a situation where sampling points 1,2 and 3 (Figure 3.2) were located upstream of the influent to the wetland, for this reason, the concentrations were generally lower than expected at these sampling points.

During the two years of study, the vegetation in FWS \#1 exhibited some areas where no growth was observed. This lack of plant life could potentially lead to a reduction in plant-mediated treatment. These bald spots were visible in the aerial 
photograph from 2003, and were absent in the photograph from 1996 (Appendix A). The bald areas had diminished in size by the second year of the study, but were still present.

The TSS (Figure 4.12) concentrations within FWS \#1 were erratic throughout the entire first year of sampling. The random nature of the measured TSS values was discussed in the previous section.

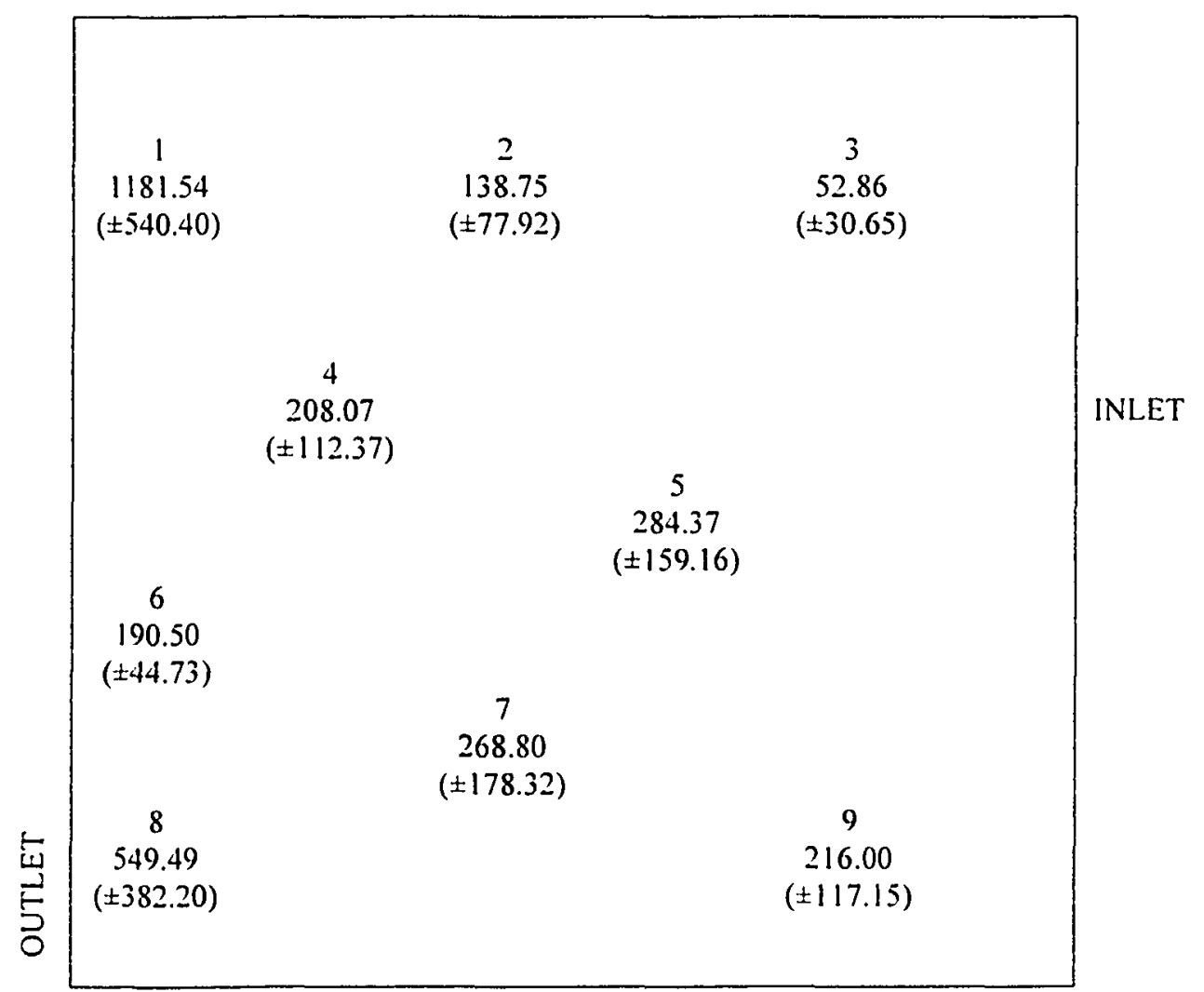

Figure t.12 TSS Concentrations ( $\pm 95 \%$ (I) in FWS \#1 Water Column Samples (2003)

The TP concentrations (Figure 4.13) within the cell remained relatively constant throughout. This demonstrated that steady state conditions had been more than likely attained for TP removal in FWS \#1. The sorption sites within the sediment zones have either been exhausted or their access has been blocked by increased sediment density or the formation of a bacterial slime layer; thus there is no removal by sorption. The bald areas of the cell may have added to this steady state by reducing the amount of vegetation 
present for plant uptake of available phosphorous, which accounts for a minor portion of the phosphorous removal.

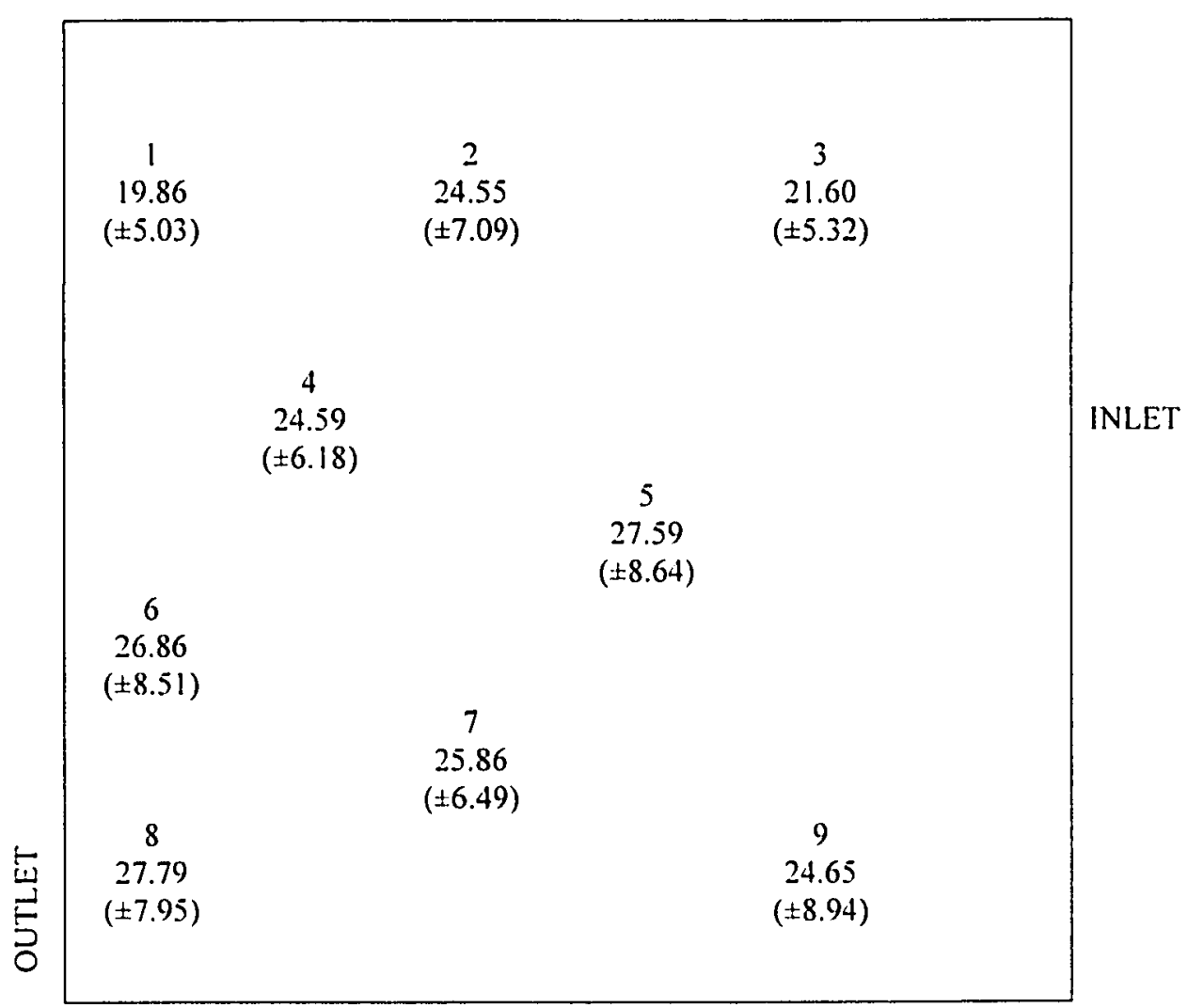

Figure t. 13 TP Concentrations ( $\pm 95 \%$ CI) in FWS \#l Water Column Samples (2003)

The ammonia concentrations (Figure 4.14) would appear to demonstrate an increasing trend towards the effluent of the cell at point 8 . However, due to the variability of the bi-weekly sample concentrations, there was no notable significant difference in concentrations between the sample points within the cell. Sample points 1 and 2 received negligible quantities of the tracer during the tracer test, and thus lower wastewater constituent concentrations would be expected in these regions, which was observed and is shown in Figure 4.14. 


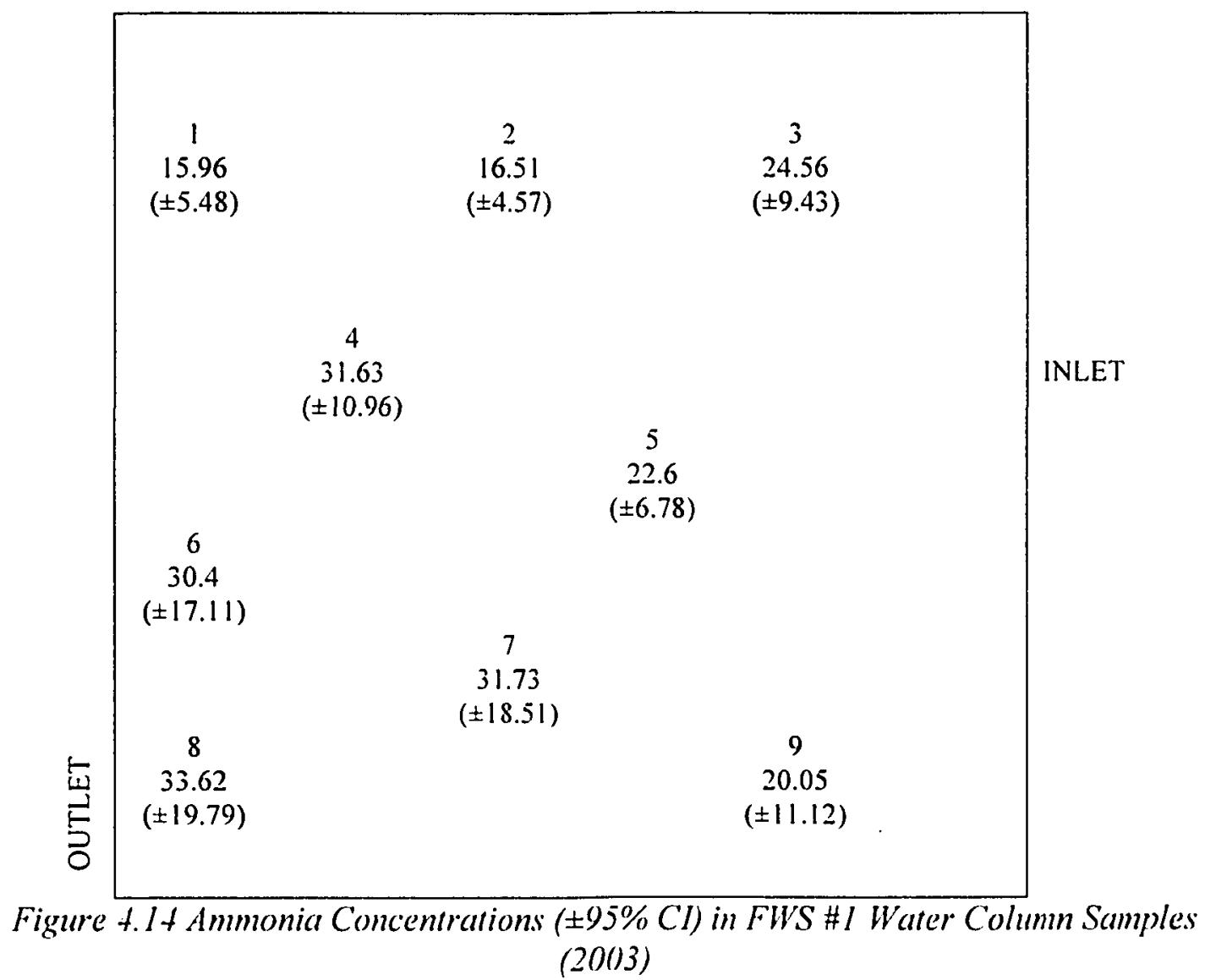

The nitrate concentrations remained consistently low and. therefore. no significant change in concentration was observed (Appendix B).

The TKN concentrations (Figure 4.15) within the cell appeared to demonstrate an increasing trend from points 5 towards the effluent point 8 . This trend was similar to that observed with respect to ammonia as well, since ammonia is one of the forms of nitrogen analyzed as TKN, this was expected. However, the statistical analyses indicated that this trend was not significant most likely due to the variability in the bi-weekly sample concentrations. 


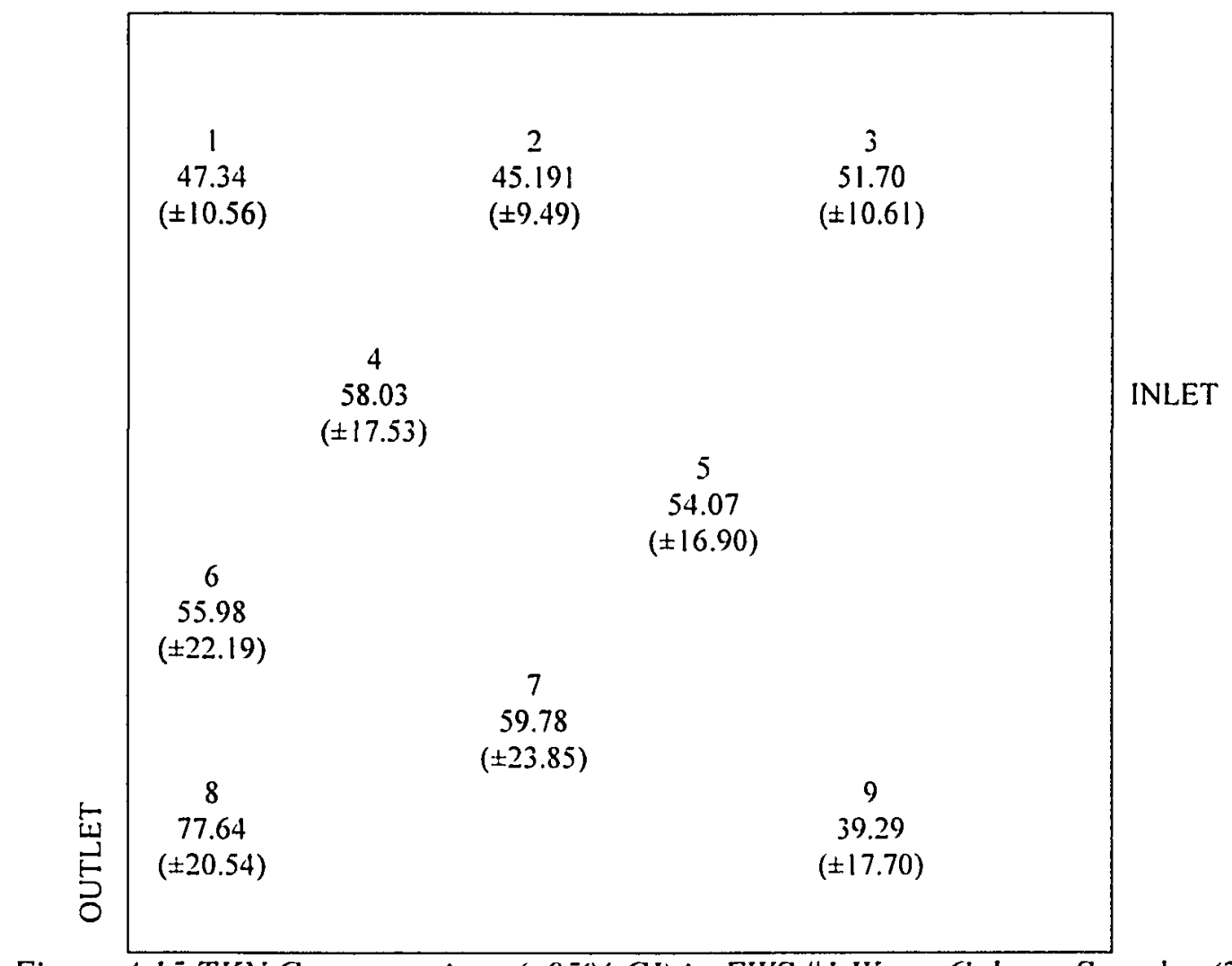

Figure +.15 TKN Concentrations ( $\pm 95 \%$ CI) in FWS \#I Water Column Samples (2003)

For the first year (2003) of the study in the first cell, there was a visible correlation between TSS and $\mathrm{BOD}_{5}$ (Figure 4.16), as the average TSS increased, the average $\mathrm{BOD}_{\mathbf{s}}$ concentration increased as well. The higher $\mathrm{BOD}_{\mathbf{s}}$ concentration at sampling points 5,6 and 7 was because those were the first points to receive the influent wastes. There was a slight decreasing trend in average $\mathrm{BOD}_{5}$ concentration towards the effluent at point 8 . 


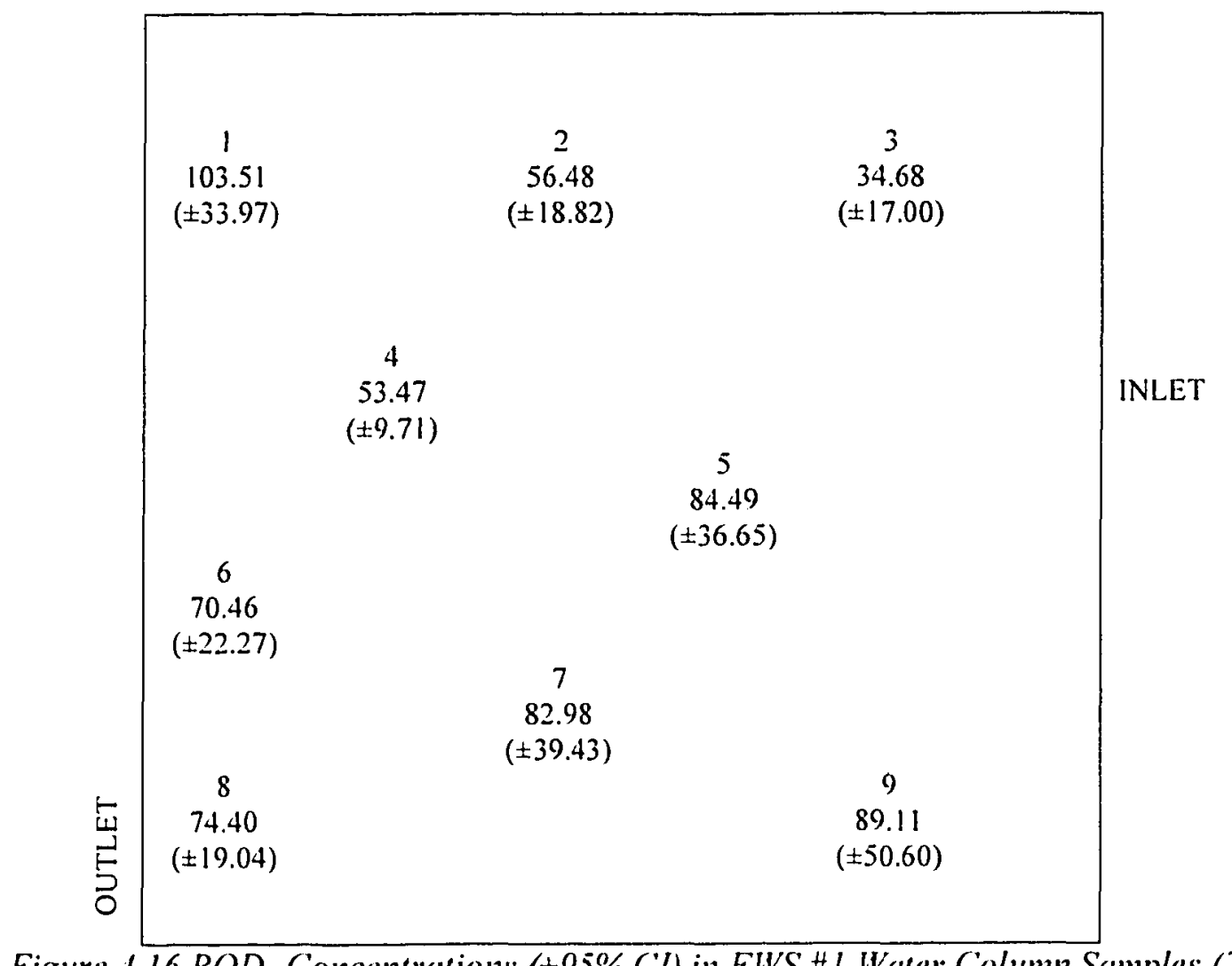

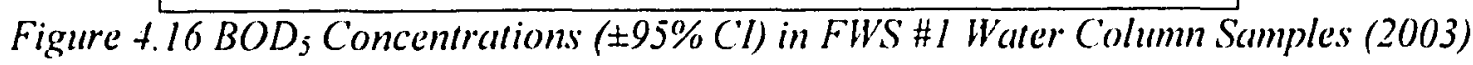

In 2004, the header was replaced as the inlet to the wetland, which allowed for the comparison of the two different flow dynamics; point source versus line source.

During the second year of the sampling. the problems associated with sediment disturbance during sampling were also resolved. The sampling mechanism was raised to a shallower depth within the water column. The TSS distribution (Figure 4.17) throughout the cell demonstrated no significant change. The peak at point 3 can be attributed to an anomaly in the data, but unfortunately only one sample could be drawn from point 3 which resulted in an elevated TSS concentration. Further sampling events could have been used to determine if this concentration was incorrect, however a problem with the sampling tube inhibited further sampling. Point 5 resulted in a lower concentration than expected (based on the profile of average concentrations), this will be 
discussed in Section 4.3 and could be a result of greater settling area around the sampling station, or a lower flow area.

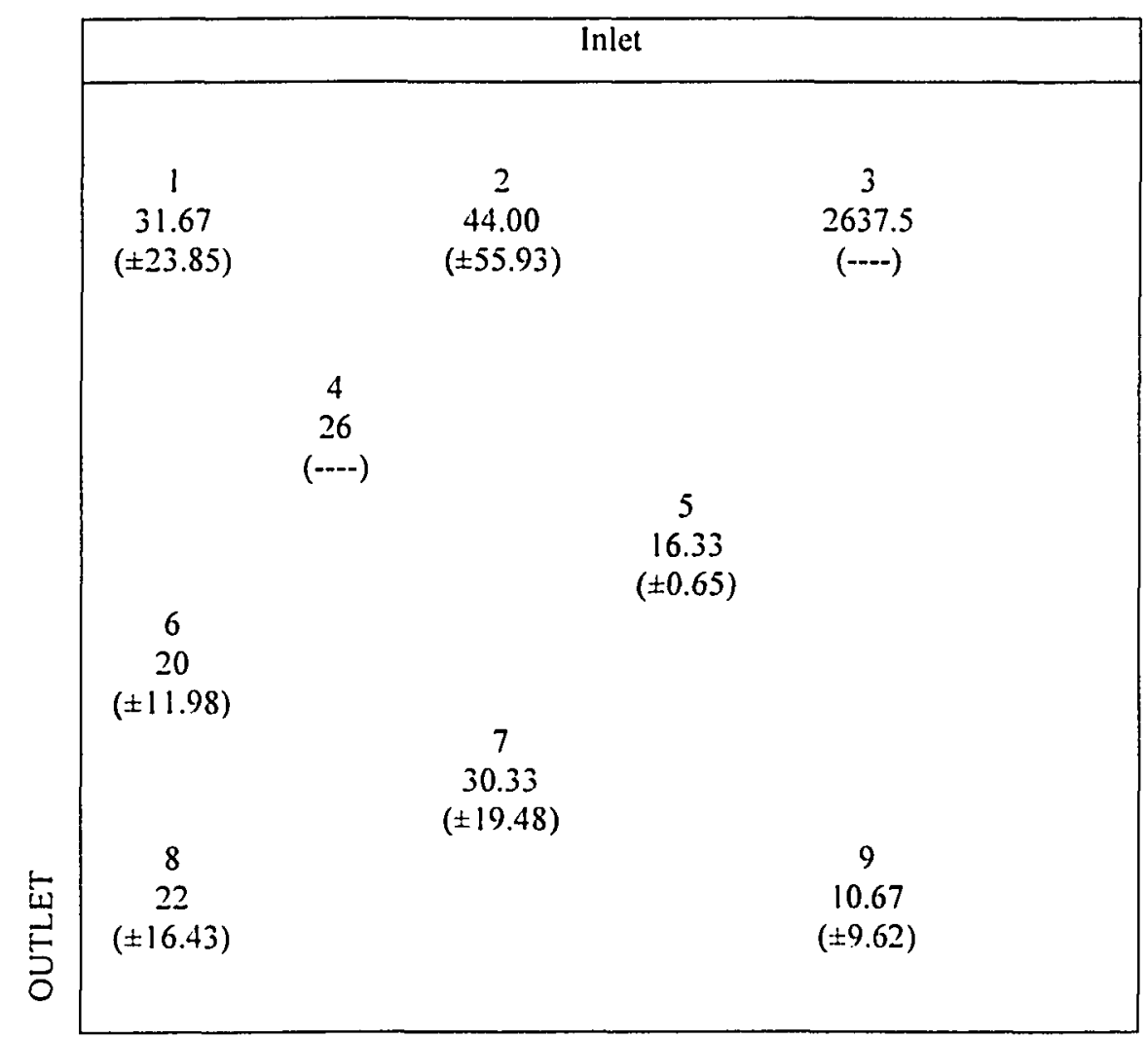

Figure +.17 TSS Concentrations ( $\pm 95 \%$ (I) in FWS \#1 Water Column Samples (2004)

The TP concentrations (Figure 4.18) throughout the cell demonstrated no significant reduction in concentration along the length of the cell. This supported the relatively steady state concentrations measured in the previous year. The bald spots within the cell were diminished in the second year, which implies that there might have been more plants within the cell for the uptake of phosphorous. 


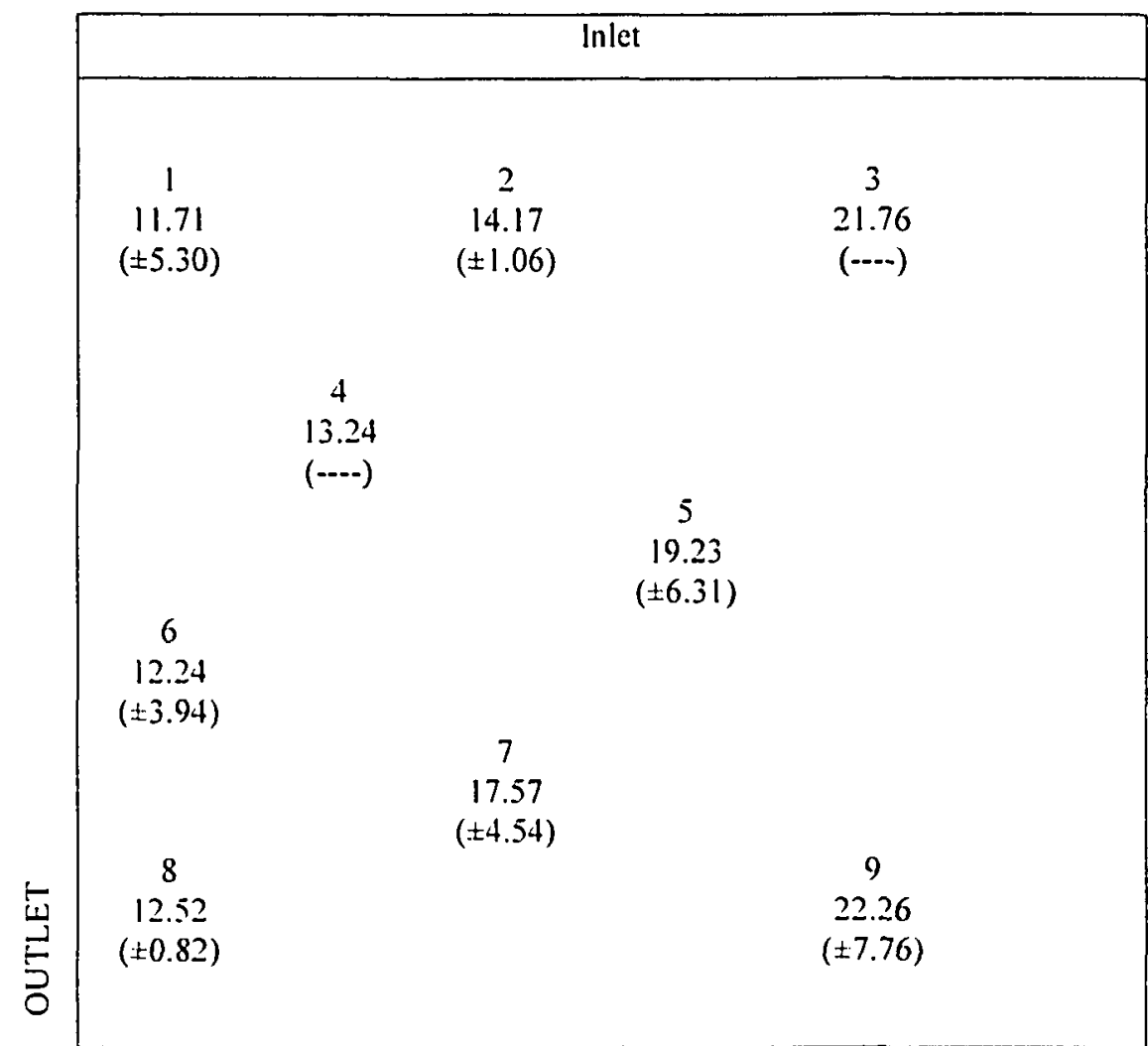

Figure t.18 TP Concentrations ( $\pm 95 \%$ CI) in FWS \#I Water Column Samples (2004)

The ammonia concentration distribution within the cell also demonstrated no significant change, due to the variability of the sample concentrations, although the average concentrations appeared to demonstrate a reduction throughout the cell (Figure 4.19). Point 5 demonstrated a peak in ammonia concentration. which could most likely be attributed to a high concentration of birds surrounding that area of the cell. The nitrate concentrations remained low through the entire cell (Appendix B). 


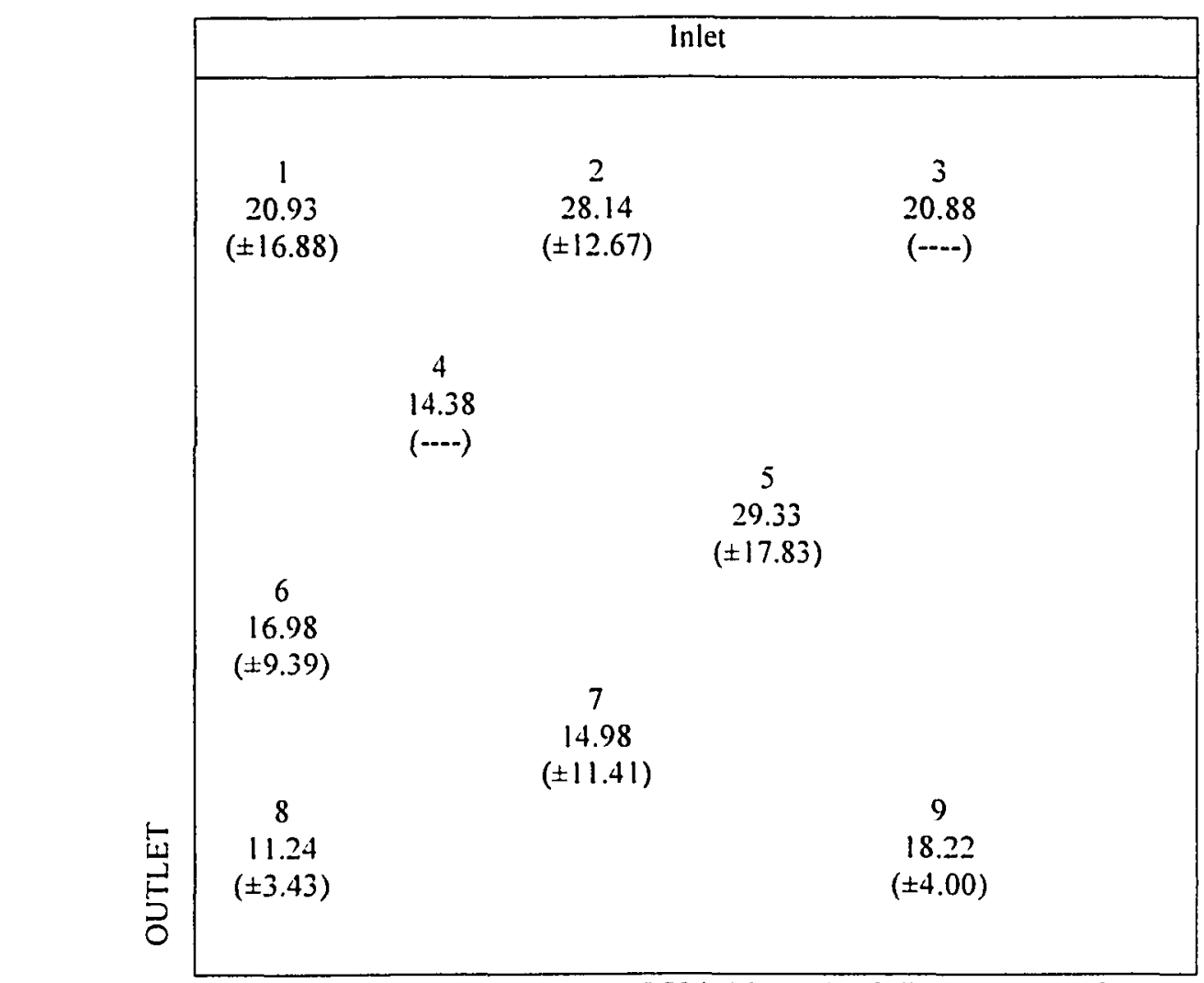

Figure t.19 Ammonia Concentrations ( $\pm 95 \%$ CI) in FWS \#I Water Column Samples $(2004)$

The concentrations of $\mathrm{BOD}_{5}$ (Figure 4.20) did not change significantly throughout the cell. Point 2 demonstrated the lowest average concentrations along the inlet line of the cell and point 5 had the lowest average concentration within the entire cell. As the TSS concentration was also low at point 5 (Figure 4.17); the lower than expected TSS concentration was probably related to the low organic content at the sampling point. 


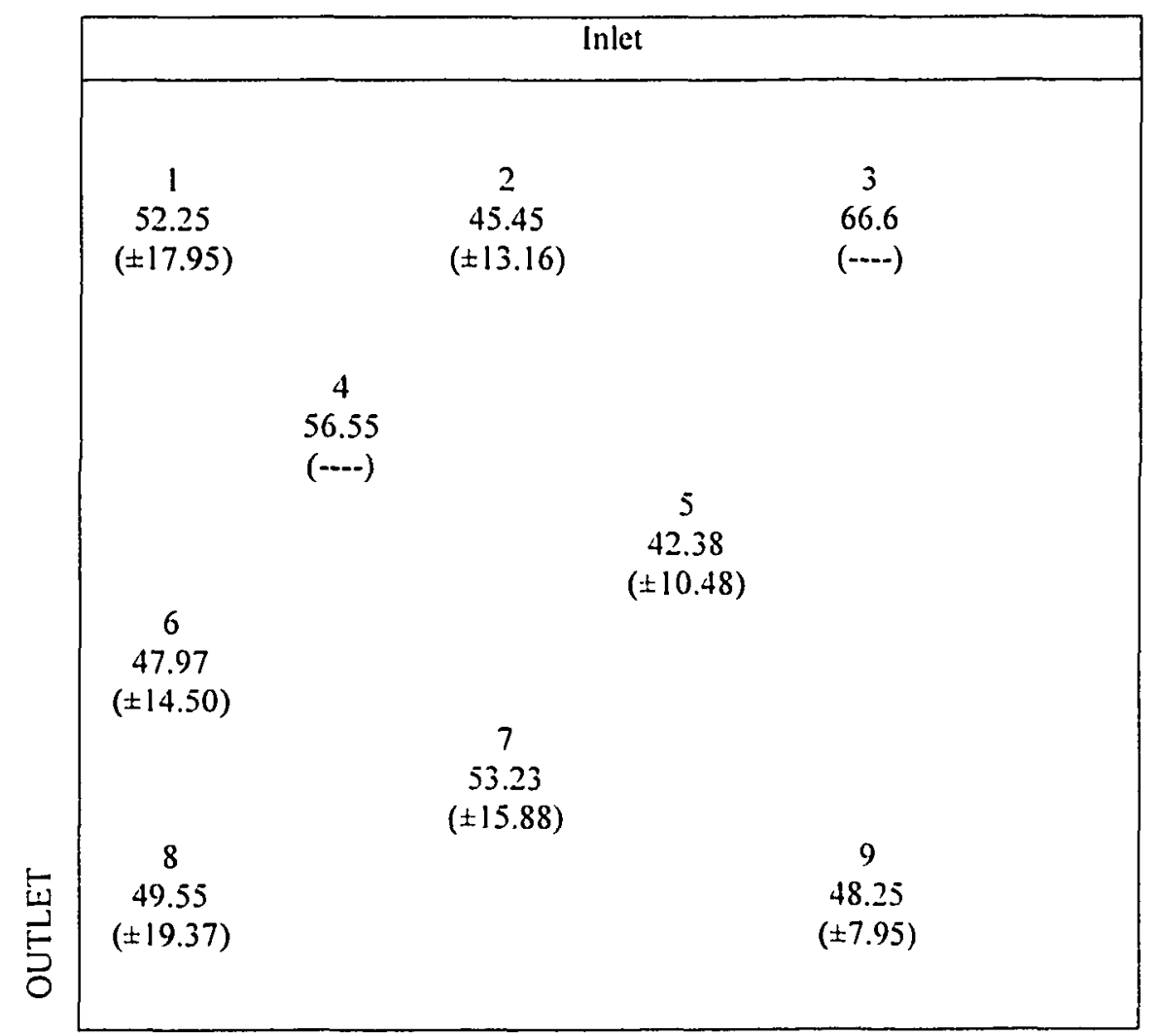

Figure 4.20 BOD Concentrations ( $\pm 95 \% \mathrm{CI}$ ) in FWS \#1 Water Column Samples (200t)

Samples were drawn from the sediments during the first year (2003) of the study. The samples were analyzed for nitrogenous species (TKN, ammonia and nitrates) as well as TP. The first observation that can be made about the concentrations in the sediments is that the TP concentrations (Figure 4.21) were generally found to be higher in the water samples, whereas the nitrogenous species concentrations were typically higher in the sediment zones. 


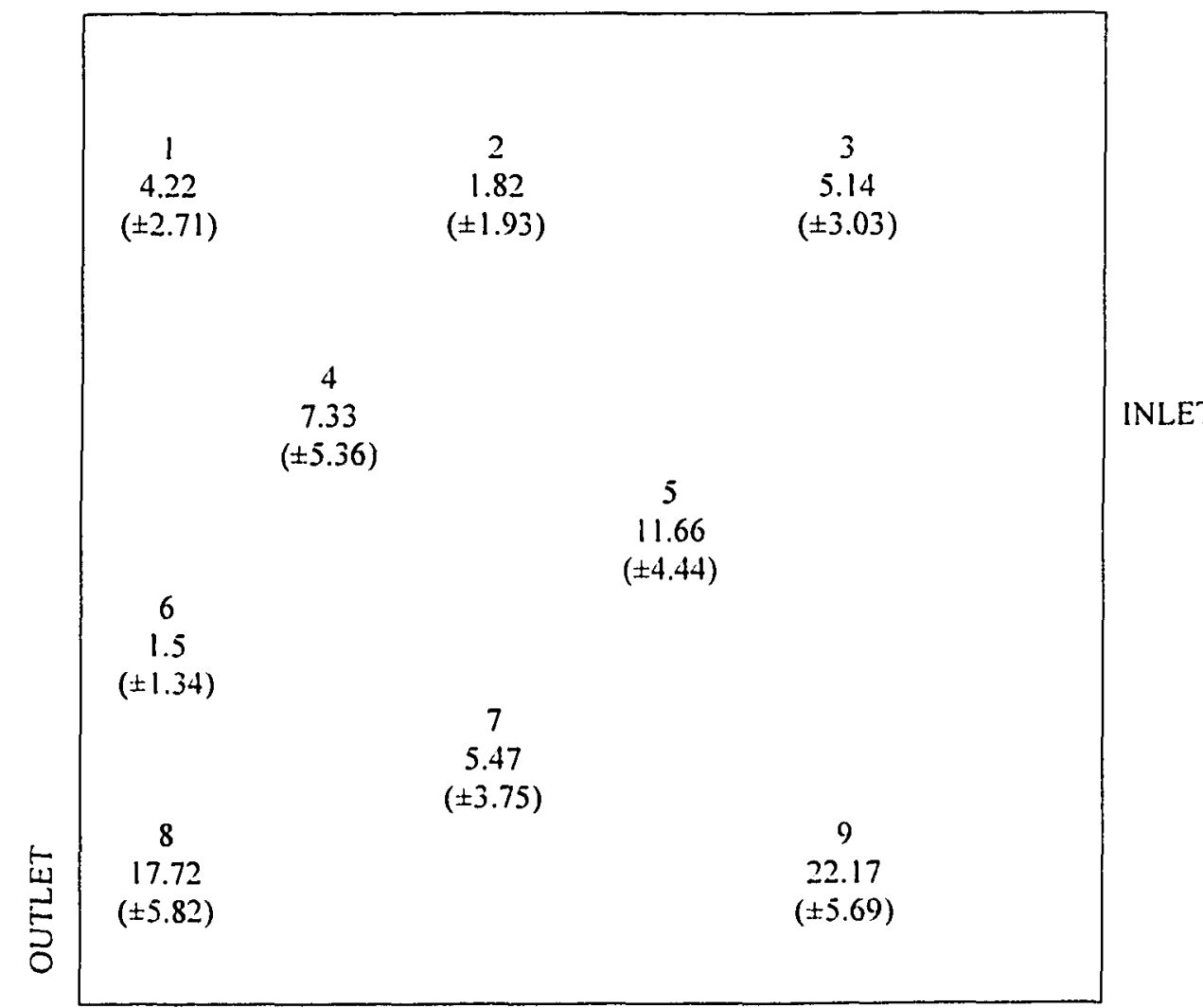

Figure t.21 TP Concentrations ( $\pm 95 \%$ (I) in FWS \#I Sediment Samples (2003)

The average ammonia concentrations exhibited the similar trends in the sediment (Figure 4.22) and in the water column where the average ammonia concentrations increased towards the effluent (Figure 4.14). The nitrate concentrations were consistently low even in the sediments of the system. The average TKN concentrations (Figure 4.23) increased towards the effluent. The maturation of FWS\#1 resulted in a decrease in the removal of all wastewater constituents, overgrowth of plants blocked sunlight from the water surface, phosphorous sorption sites were depleted. or blocked by the high amount of sediments. 


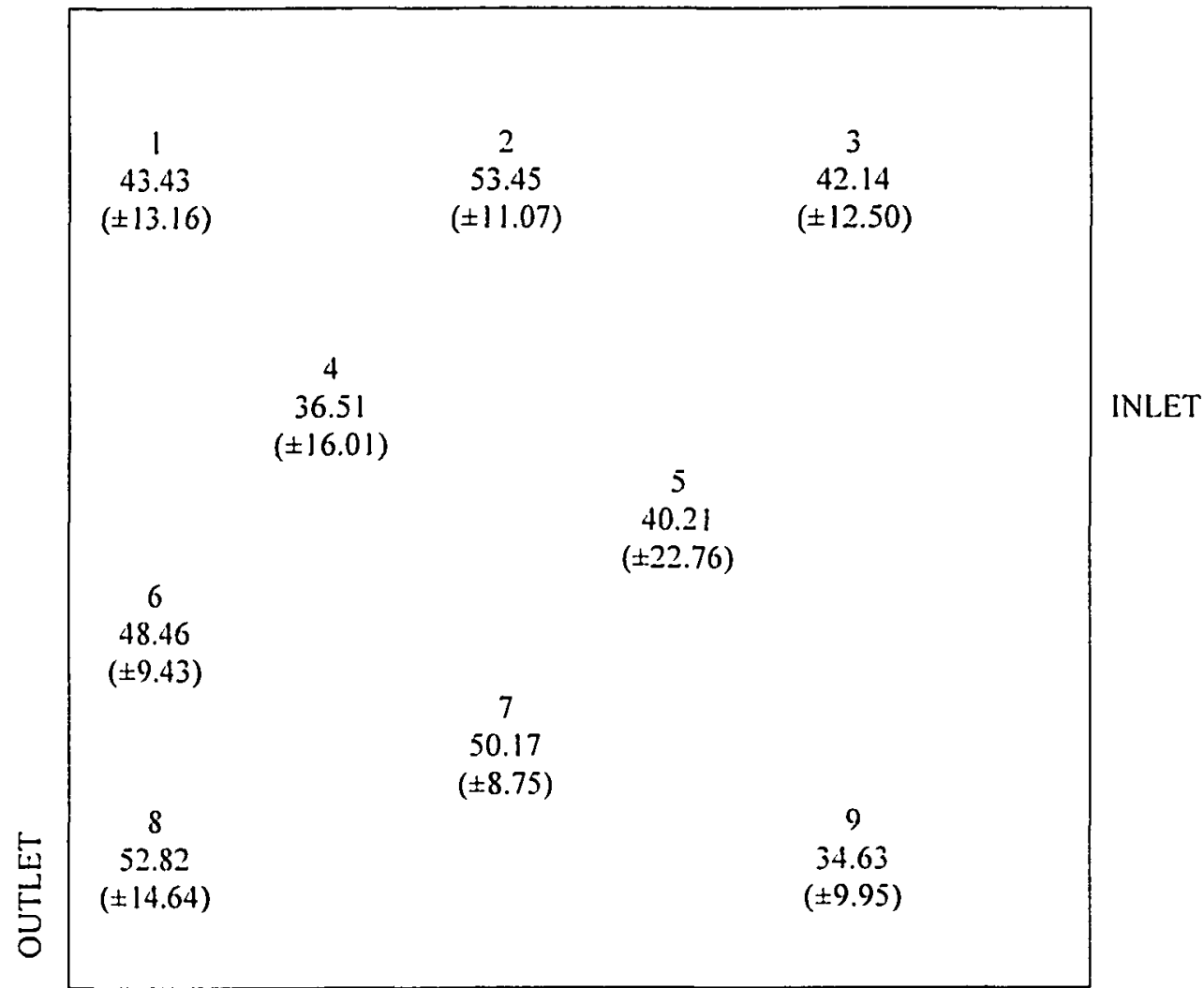

Figure 4.22 Ammonia Concentrations ( $\pm 95 \%$ CI) in FWS \#I Sediment Samples (2003)

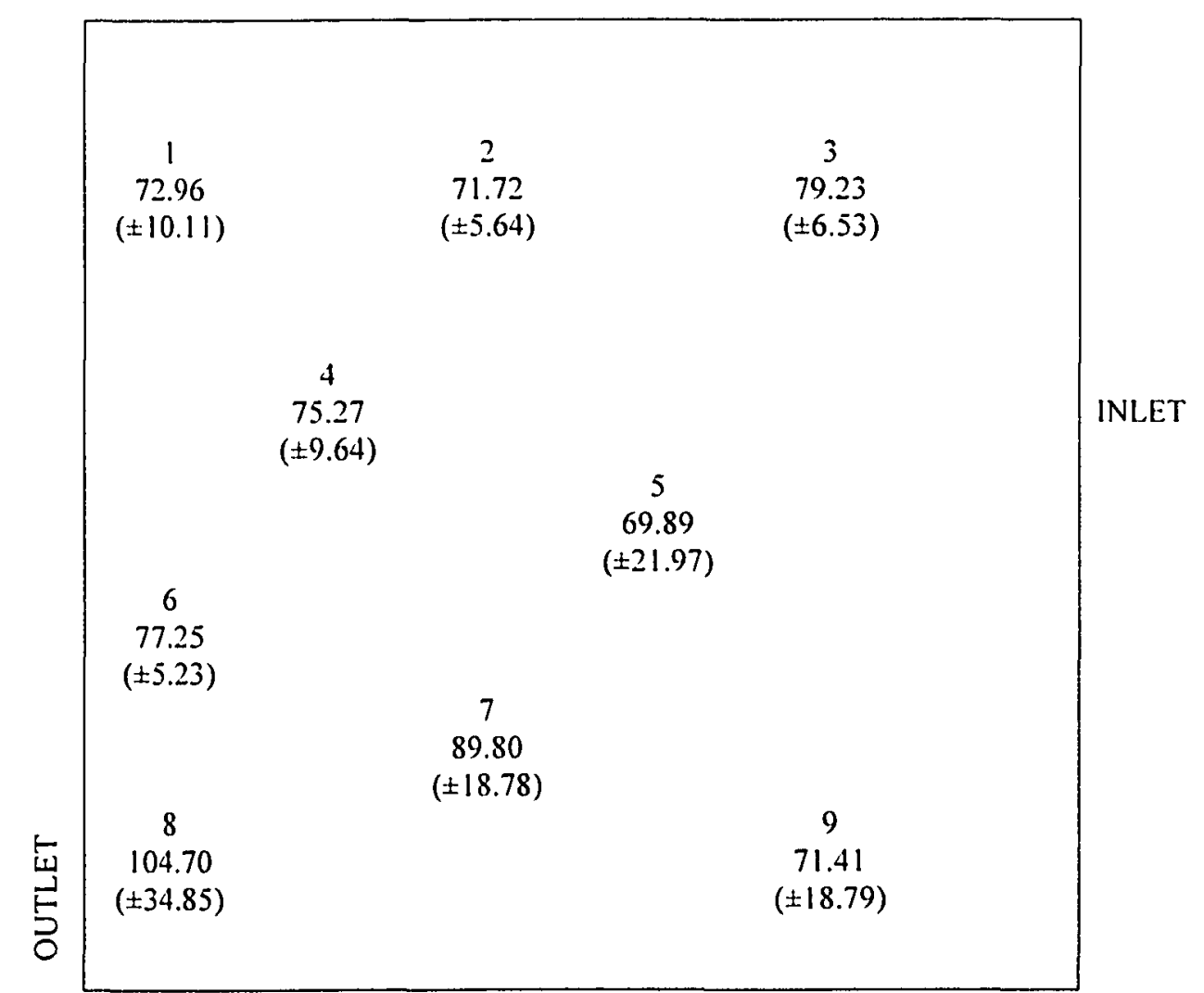

Figure 4.23 TKN Concentrations ( $\pm 95 \%$ C1) in FWS \#l Sediment Samples (2003) 


\subsubsection{Pond Cell (Pond)}

The pond cell was only monitored during the first season of the study. The cell was designed as an aerobic pond, a step required for the effective reduction of ammonia concentrations through nitrification. The cell was initially designed to be unvegetated, but as years passed, plant life began invading the cell. This is evident from the two aerial photographs presented in Appendix A. The photograph from 1996 shows the cell just after the commencement of the system, there is no vegetation within the perimeter of the cell. The photograph from 2003 shows that the vegetation has encroached into the pond. thus, reducing the unvegetated area of the cell and changing the treatment dynamics. The vegetation encroaching into the cell blocks wind driven aeration, as well as increases the sediments around the plants through filtration (discussed in Section 4.3).

The majority of the constituents showed a trend of decreasing average concentrations from the northern bank to the southern bank (Appendix A, Figure 3.3). This was primarily due to the point inlet on the northern bank introducing the wastewater such that flow moved directly toward the outlet. The dispersion flow caused the constituents to reach the southern edge of the pond. but the concentrations were much smaller than the concentrations of the bulk flow along the north side of the pond.

The suspended solids (Figure 4.24) exhibited similar average concentration profiles along all three sampling planes. The large surface area of the pond and the slow flow rate are conducive to the settling of solids, therefore, it would be expected, in most situations, for the suspended solids concentrations to decrease. The sunlight and aeration of the pond are perfect for the growth of algae, which tend to be characterized as 
suspended solids in laboratory analyses. Algal growth, resulting in suspended solids concentrations remaining constant, is not unusual in natural systems.

\begin{tabular}{|ccc|}
\hline INLET & & \\
I & II & III \\
50.33 & 20.44 & 32.00 \\
$( \pm 24.69)$ & $( \pm 8.69)$ & $( \pm 18.28)$ \\
& & \\
IV & V & VI \\
46.10 & 20.11 & 18.67 \\
$( \pm 21.06)$ & $( \pm 7.48)$ & $( \pm 10.78)$ \\
& & \\
& & \\
VII & VIII & IX \\
43.93 & 35.67 & 22.00 \\
$( \pm 15.05)$ & $( \pm 13.81)$ & $( \pm 7.10)$ \\
& OUTLET & \\
\hline
\end{tabular}

Figure t.2+ TSS Concentrations ( $\pm 95 \%$ Cl) in Pond cell Water Column Samples (2003)

The TP concentrations within the cell remained relatively constant (Appendix B). indicating that cell was nearing a steady state with respect to phosphorous removal. This was expected, as there was minimal plant growth in the cell, and the limited sorption zones would be expected to have depleted after nine years of operation. The pond cell was designed to increase the nitrogen removal of the system, but is not expected to have a large effect on TP removal.

Average ammonia concentrations (Figure 4.25) were reduced under the aerobic conditions of the pond. This was seen in the northern section, but the average ammonia concentrations increased as the flow passed further to the south of the cells, however, due to the variability of the samples, there was no statistically significant difference. The increase in ammonia takes place as a result of the conversion of organic nitrogen to ammonia, typically at a faster rate than the ammonia is converted to nitrate. 


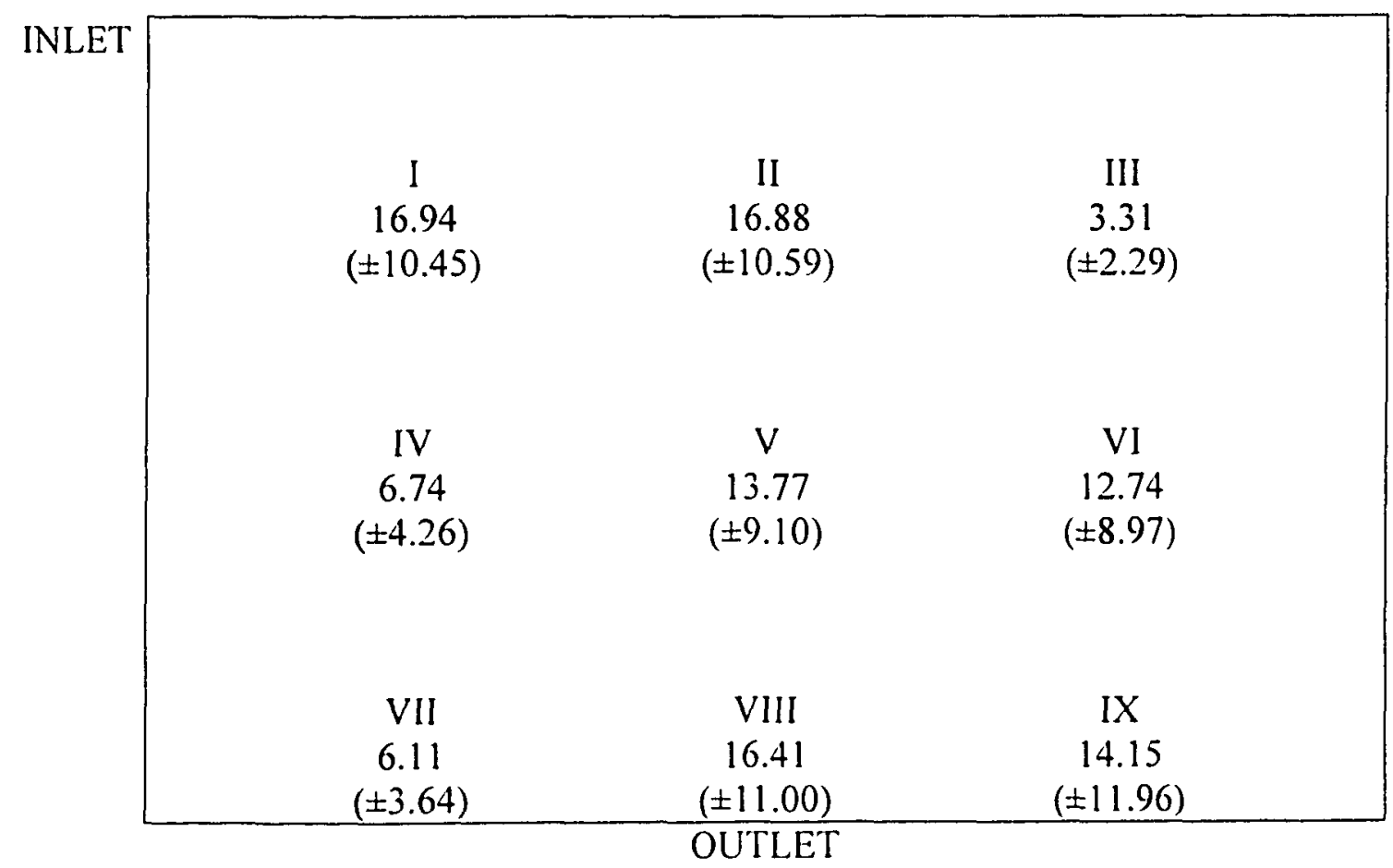

Figure 4.25 Ammonia Concentrations ( $\pm 95 \%$ CI) in Pond cell Water Column Samples (2003)

A high average nitrate concentration (Figure 4.26) could also be noted along the southern bank, where the corresponding average ammonia concentrations were higher as well. The increased nitrate concentrations indicated that ammonia reduction was occurring within the system; increased ammonia concentrations would appear to suggest that organic nitrogen was being reduced to ammonia at a greater rate than ammonia was oxidized to nitrate. 


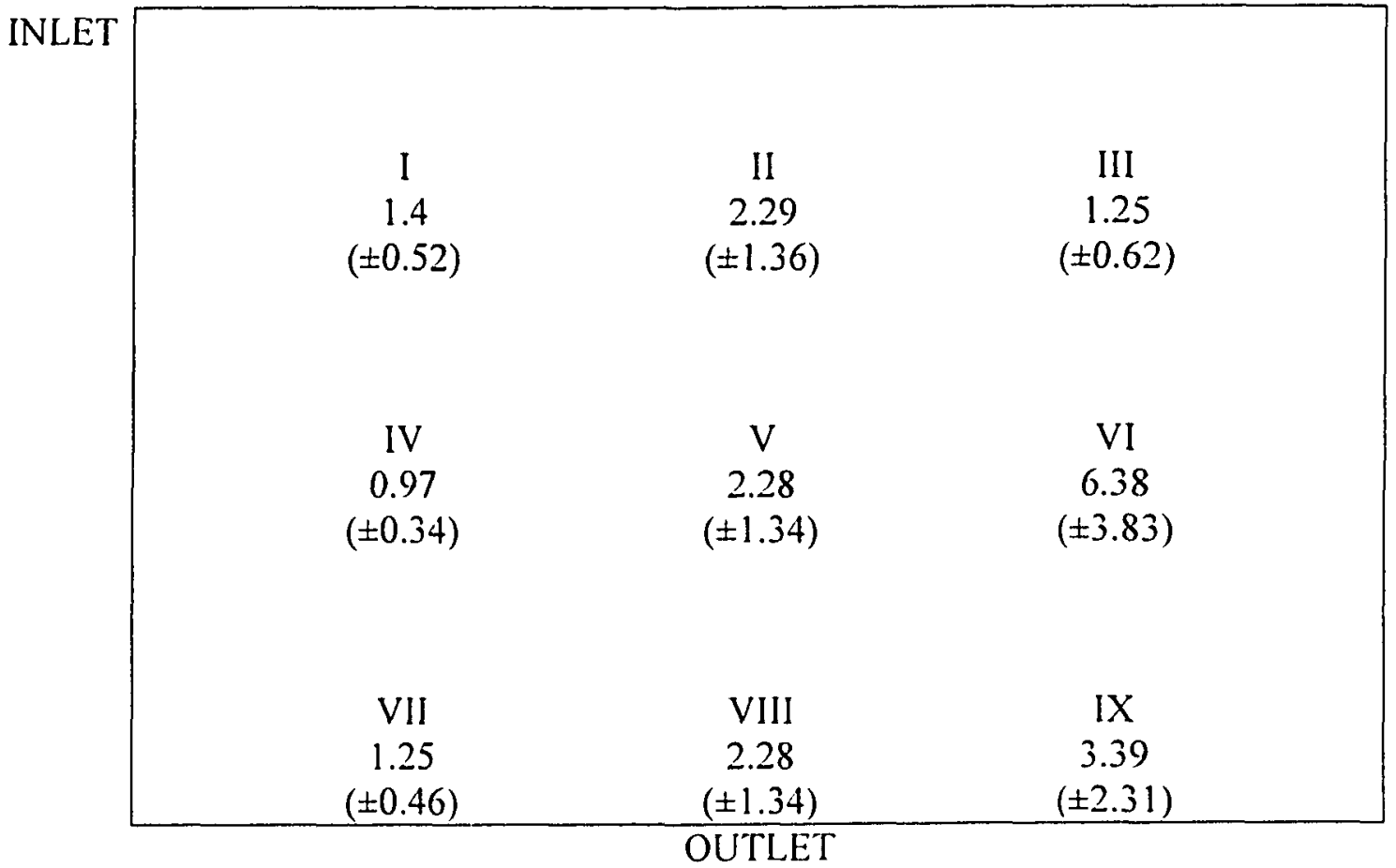

Figure t.26 Nitrate Concentrations ( $\pm 95 \%$ C.I) in Pond cell Water Column Samples (2003)

The presence of algae can also be responsible for lluctuations in $\mathrm{BOD}_{5}$ (Figure 4.27). The dead algae would be measured in the same way as other decaying organic matter. The average $\mathrm{BOD}_{5}$ concentrations in the pond cell demonstrated no notable trend. 


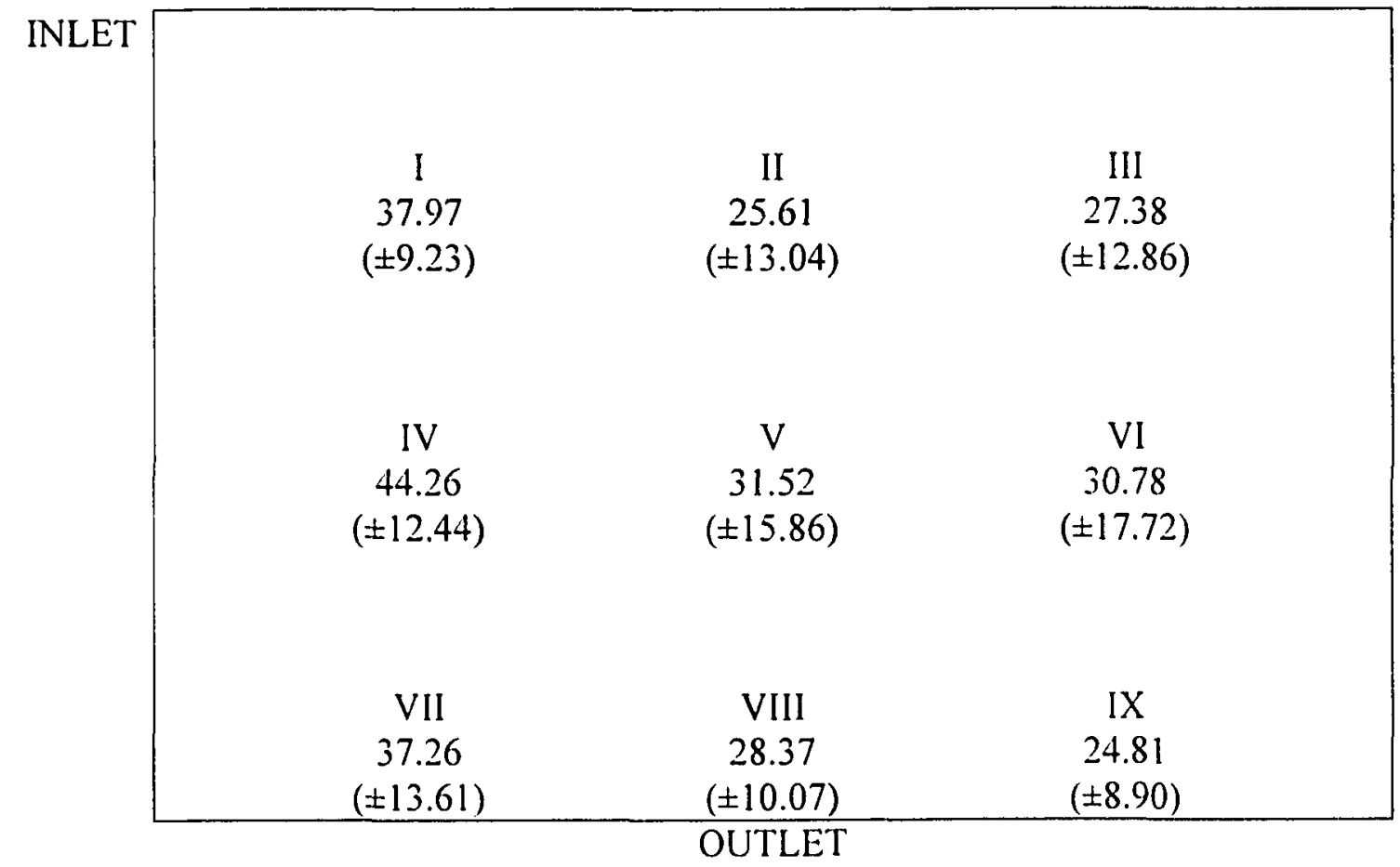

Figure 4.27 $\mathrm{BOD}_{5}$ Concentrations $( \pm 95 \% \mathrm{Cl}$ ) in Pond cell Water Column Samples (2003)

The sediment zones within the pond cell exhibited an opposite trend from that observed in the water column. The average TP (Figure 4.28) and TKN (Figure 4.31) concentrations increased towards the southern bank along the influent, and while the average TKN concentrations increased towards the south in the effluent. the average TP concentrations decreased towards the south. 


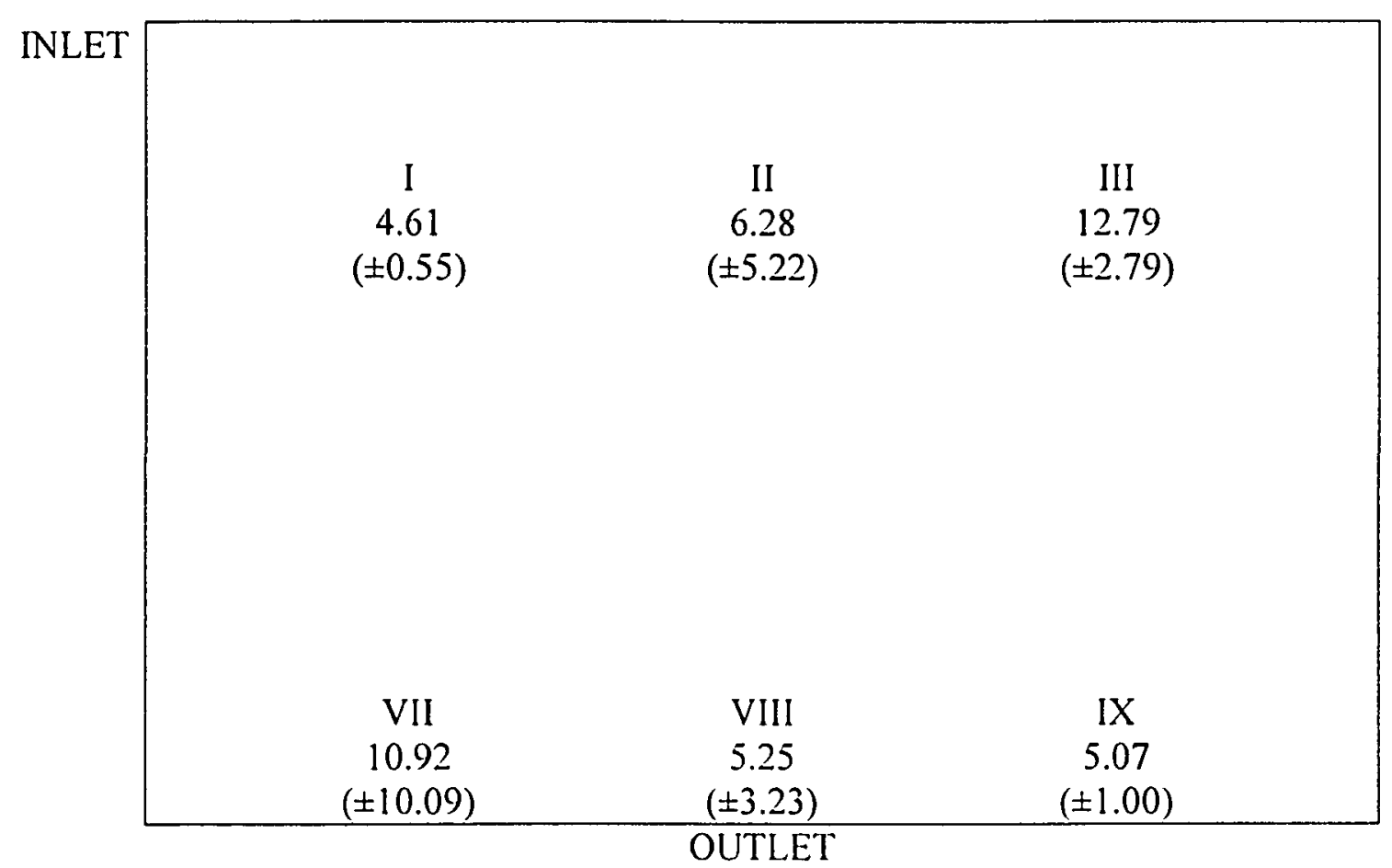

Figure 4.28 TP concentrations ( $\pm 95 \%$ Cl) in Pond cell Sediment Samples (2003)

Where the average ammonia concentrations were decreasing towards the southern bank along the inlet in the water column, the ammonia concentrations were increasing towards the southern banks in the sediment samples (Figure 4.29). Where the average nitrate concentrations increased towards the southern banks in the water column. they decreased in the sediment zone (Figure 4.30). As the pond cell matured, the main factor affecting the treatment ability of the cell was the encroachment of vegetation. This encroachment blocked wind aeration, as well as giving zones for sedimentation, which has changed the dynamic of the cell as well as its treatment ability. 


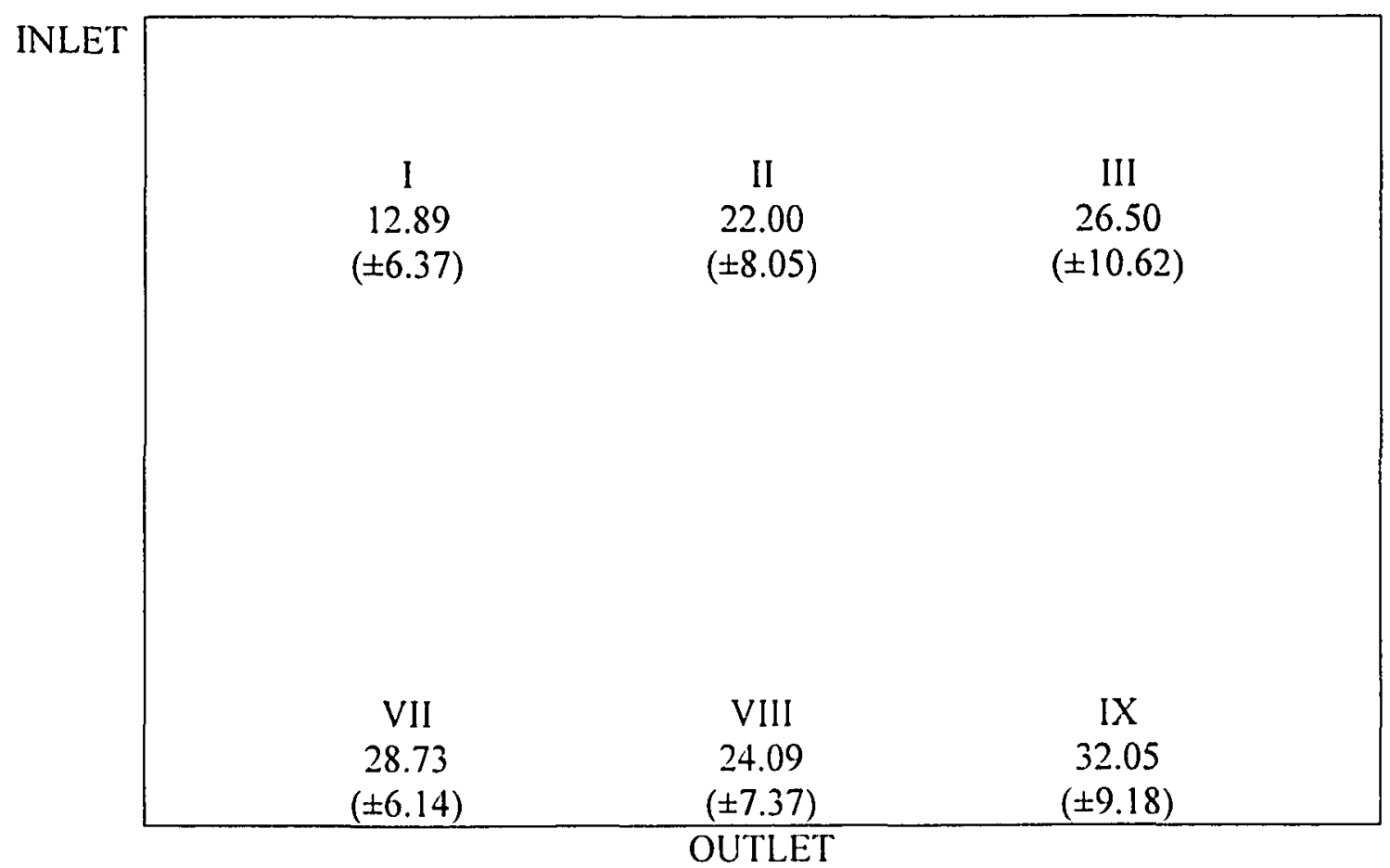

Figure 4.29 Ammonia concentrations ( $\pm 95 \%$ Cl) in Pond cell Sediment Samples (2003)

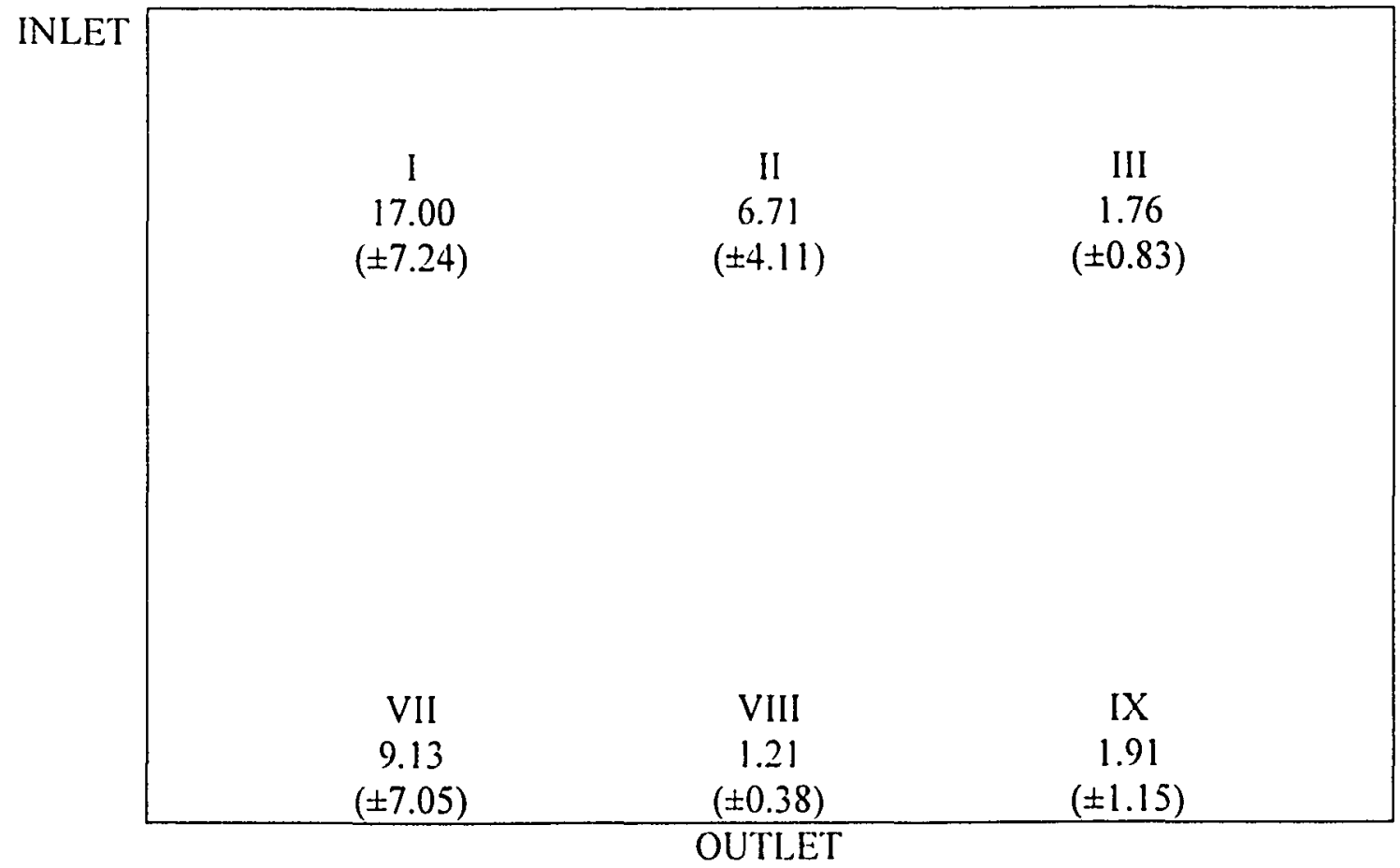

Figure 4.30 Nitrate concentrations $( \pm 95 \%$ CI) in Pond cell Sediment Samples (2003) 


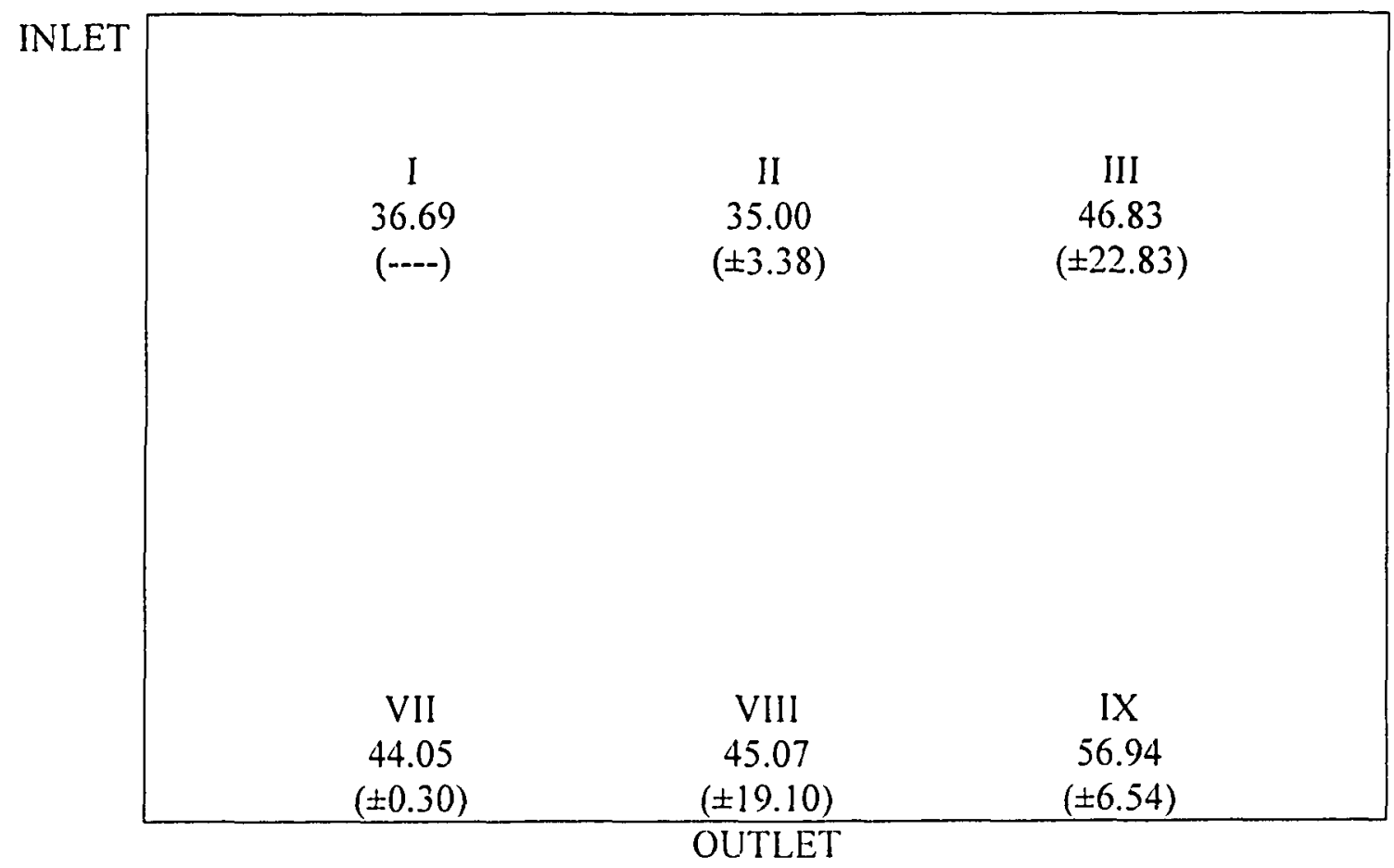

Figure 4.31 TKN concentrations $( \pm 95 \% \mathrm{Cl}$ ) in Pond cell Sediment Samples (2003)

\subsubsection{Second Vegetated Cell (FWS \#2)}

The main purpose of the third cell of the wetland was to filter the effluent from the anoxic pond cell. As was previously stated, a pond cell is an area where conditions are often optimal to promote algal growth, and the algae increases TSS and $\mathrm{BOD}_{5}$ concentrations. When the $\mathrm{BOD}_{\xi}$ and TSS are required to be lower than a standard value, the algae must be removed. As an added advantage. FWS \#2 also serves to remove more of the nutrients, resulting in a higher quality effluent.

The TSS (Figure 4.32) and $\mathrm{BOD}_{5}$ (Figure 4.35) concentrations were again erratic possibly due to the re-suspension of solids during sampling in the first year. The TP concentrations (Figure 4.33) demonstrated no significant change in concentrations throughout in the cell, indicating that the cell was close to steady state conditions (Section 4.3.3.1). 


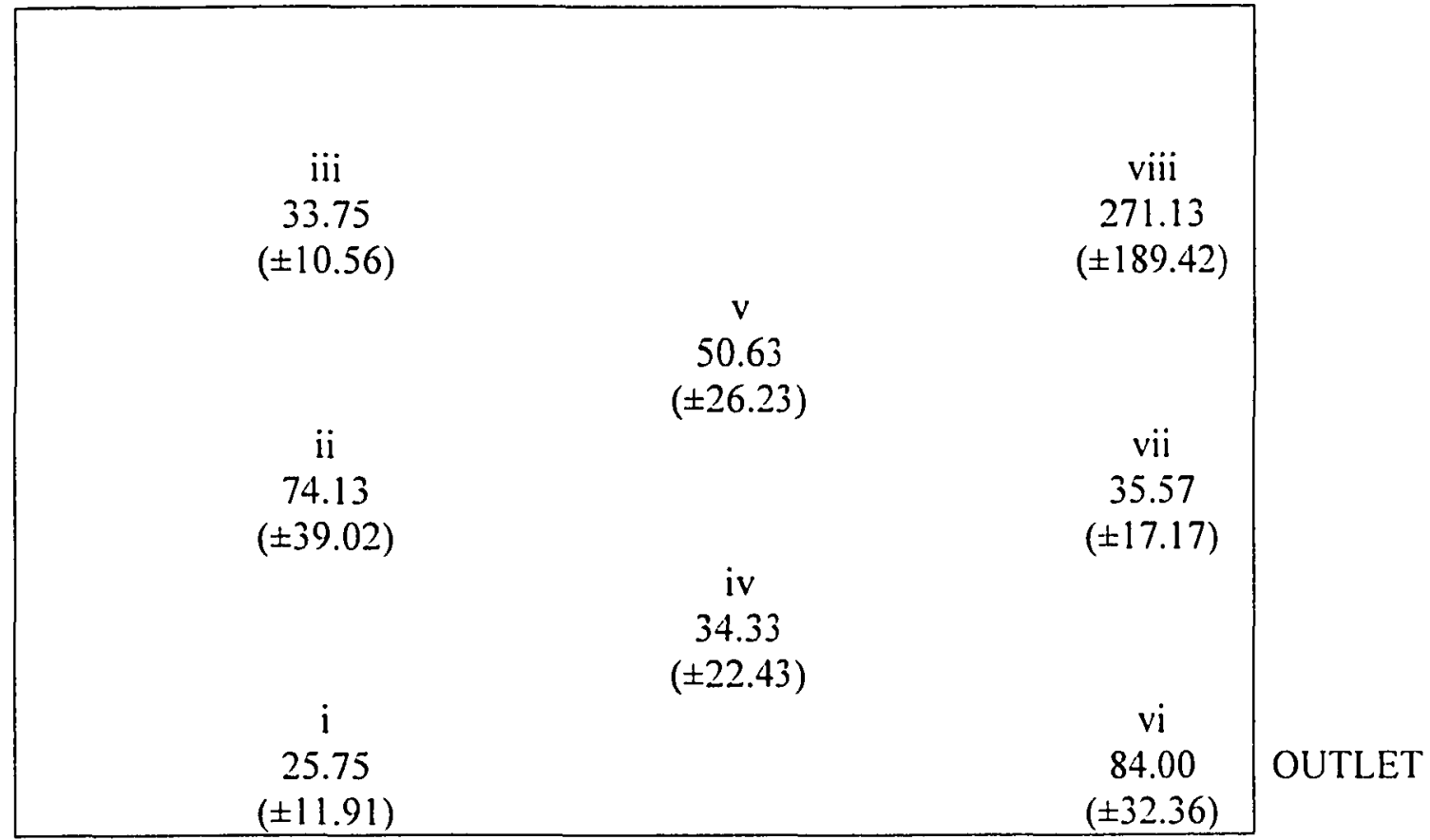

Figure 4.32 TSS Concentrations ( $\pm 95 \%$ CI) in FWS \#2 Water Column Samples (2003) INLET

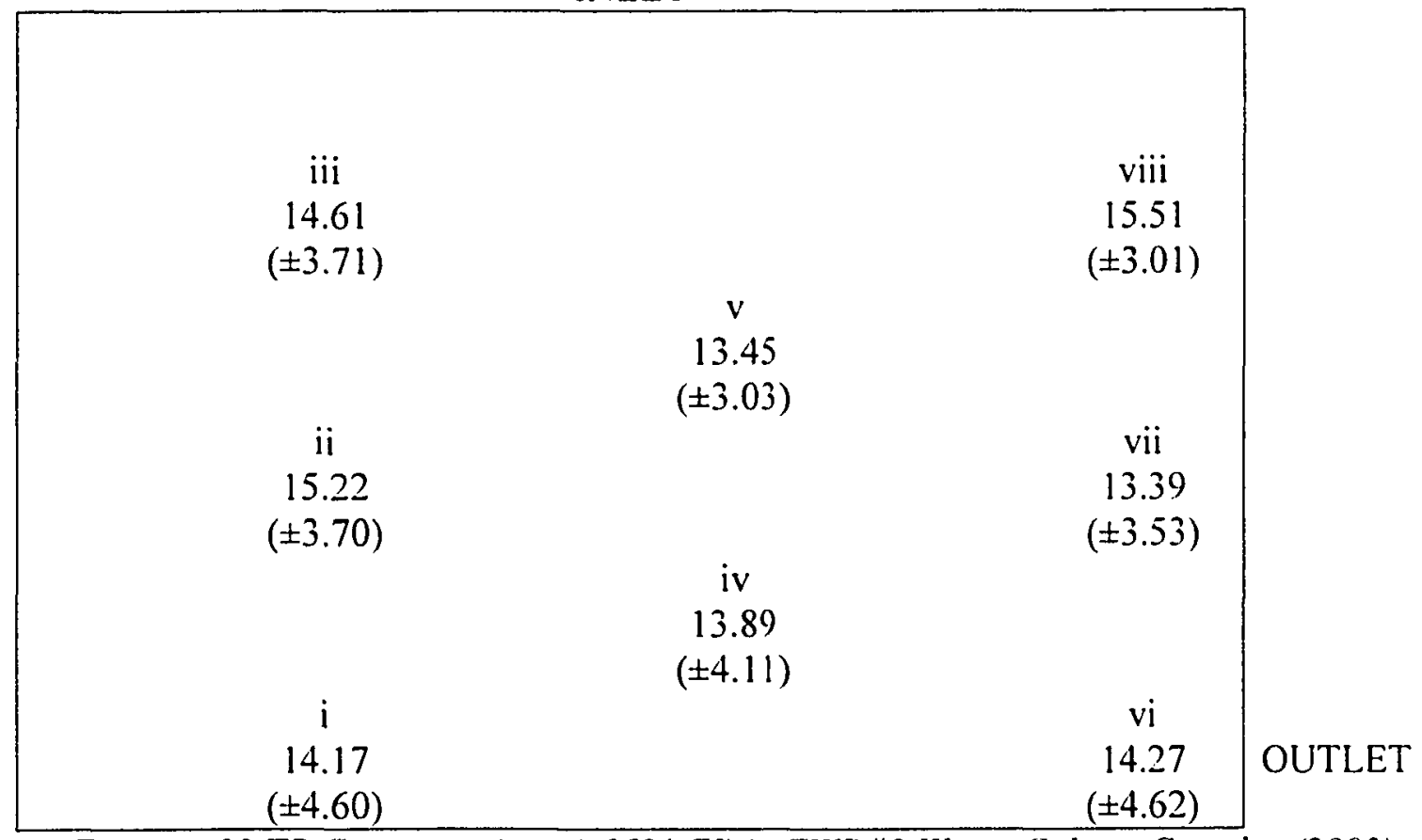

Figure 4.33 TP Concentrations ( $\pm 95 \%$ CI) in FWS \#2 Water Columm Samples (2003) 
Ammonia concentrations (Figure 4.34) also demonstrated no significant change throughout FWS \#2, although the average concentrations appeared to demonstrate a decreasing trend from the northern bank to the effluent at the southern corner, but along the southern bank little to no reduction in concentrations were observed. The nitrate concentrations remained consistently low (Appendix B), and the TKN concentrations demonstrated no significant change throughout the cell (Appendix B).

\section{INLET}

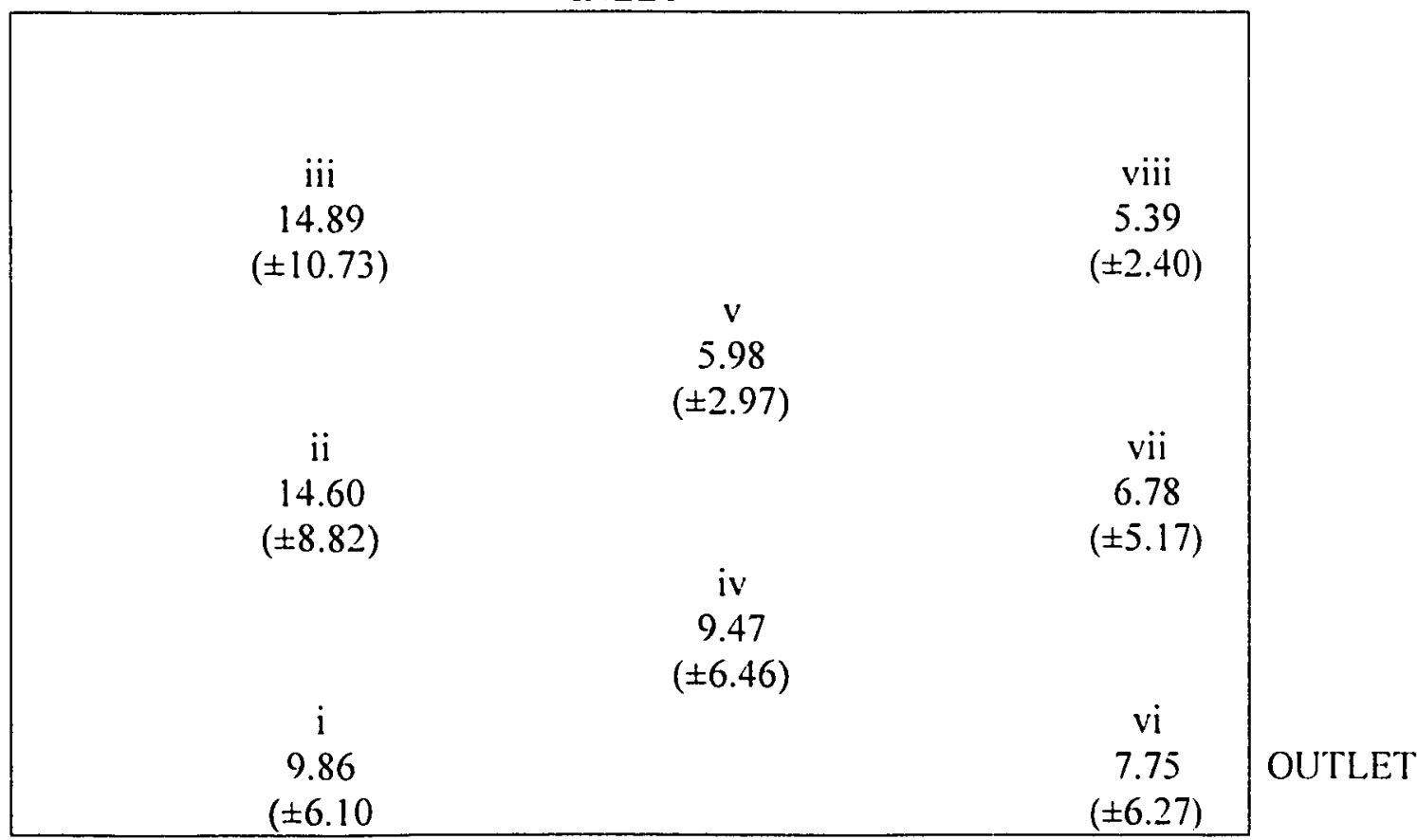

Figure t.3t Ammonia Concentrations ( $\pm 95 \% \mathrm{Cl}$ ) in FWS \#2 Water Column Samples (2003) 


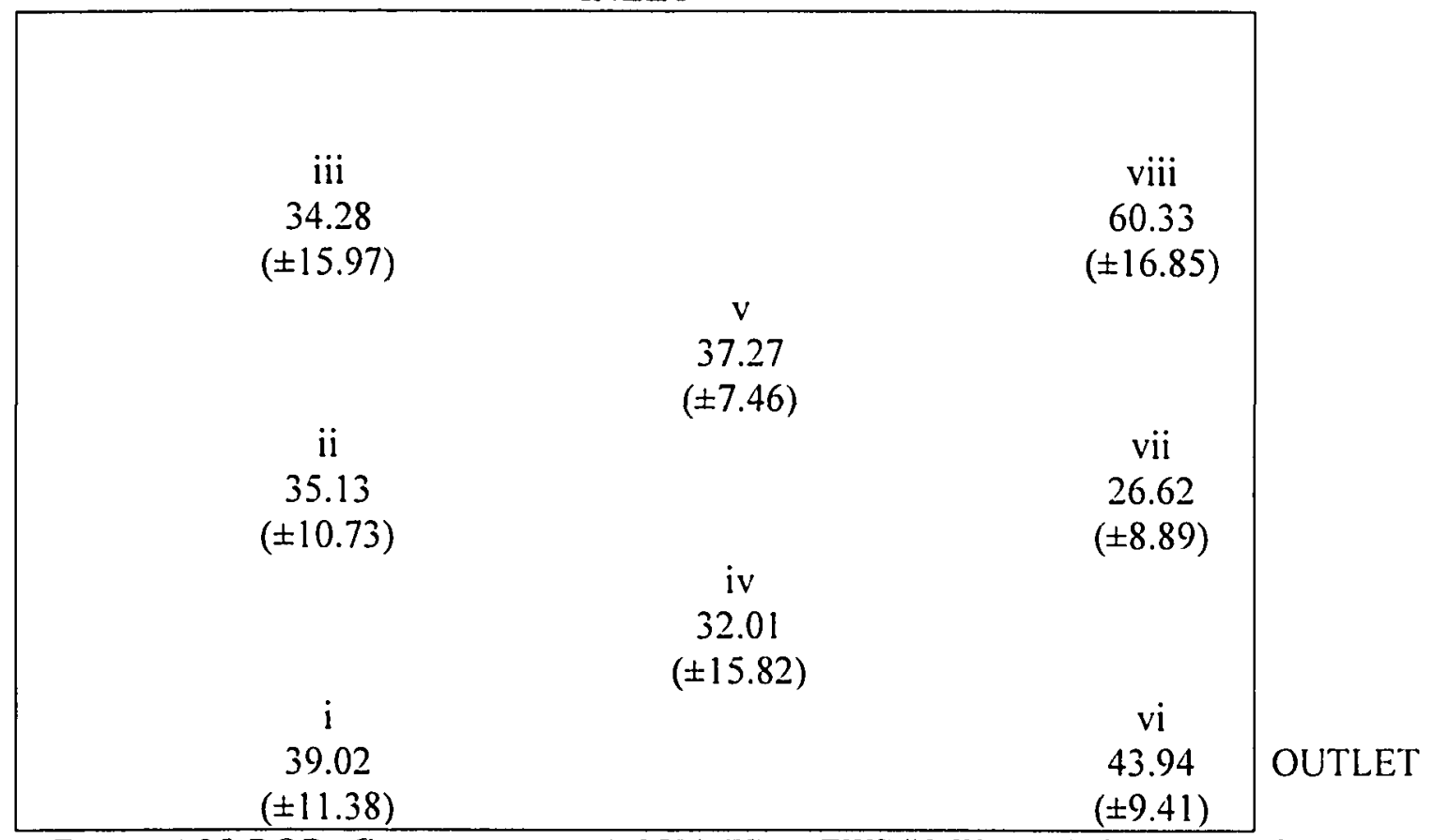

Figure $4.35 \mathrm{BOD}_{5}$ Concentrations ( $\pm 95 \% \mathrm{CI}$ ) in FWS $\# 2$ Water Column Samples (2003)

In the second year of the study, the average TSS concentrations (Figure 4.36) exhibited a decreasing trend towards the effluent, as was expected. The ammonia concentration (Figure 4.37) demonstrated a significant reduction between point iii and the outlet vi (from ANOVA: $f=7.42>f_{\text {crit }}=5.99$ ). The nitrate and TKN concentrations demonstrated no significant change in concentrations throughout the cell (Appendix B). 


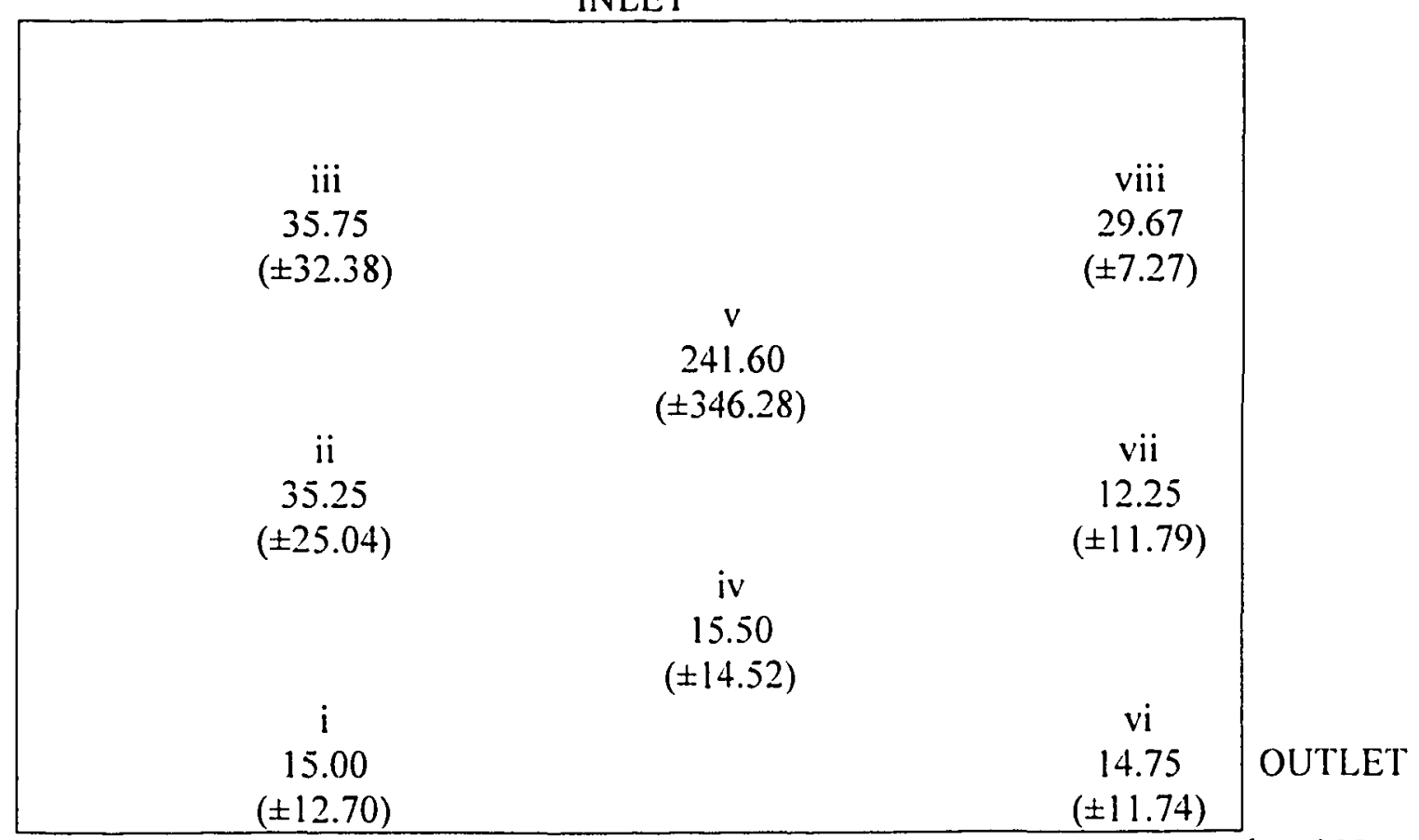

Figure t.36 TSS Concentrations ( $\pm 95 \%$ (V) in FWS \#2 Warer Column Samples (2004)

\section{INLET}

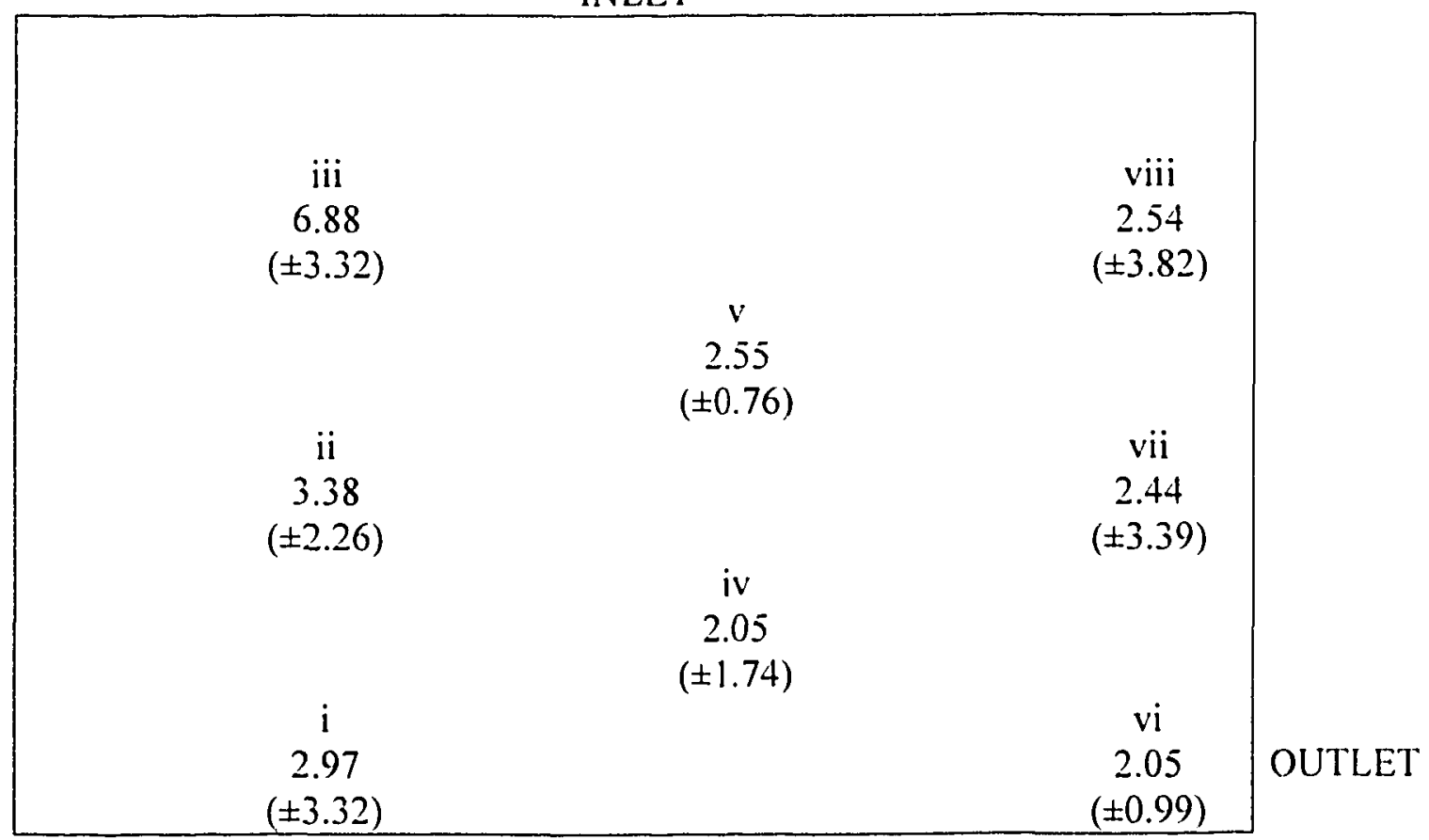

Figure t.37 Ammonia Concentrations ( $195 \%$ CI) in FWS \#2 Water Column Samples (2004) 
The average $\mathrm{BOD}_{5}$ concentrations (Figure 4.38) demonstrate no significant trend in treatment within the cell.

\section{INLET}

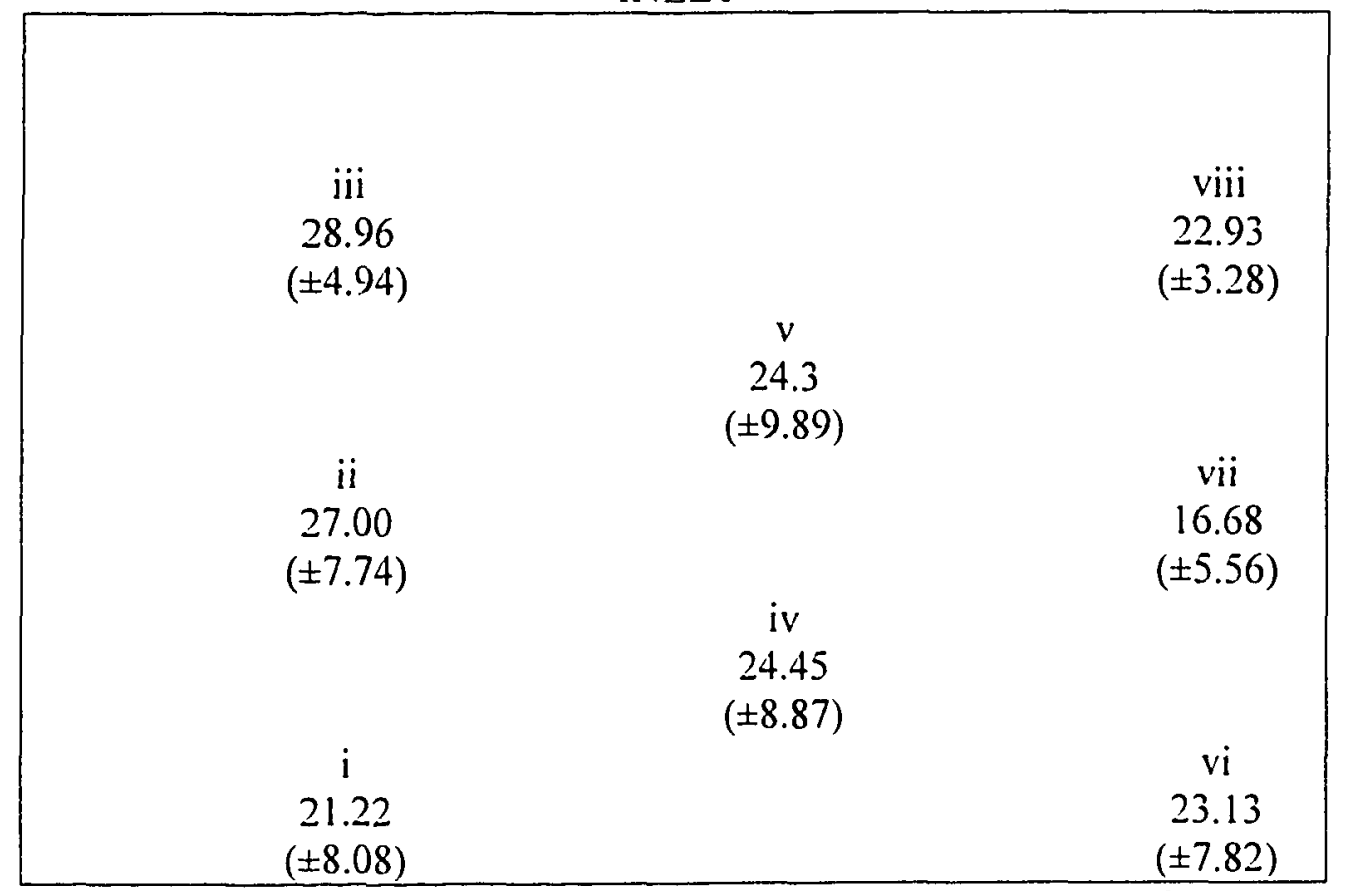

Figure $4.38 \mathrm{BOD}_{5}$ Concentrations ( $\pm 95 \% \mathrm{Cl}$ ) in FWS $\# 2$ Water Column Samples (2004)

The operation of FWS \#2 was the only aspect of the two years that remained under the same flow conditions throughout both years of the study. In FWS \#1, the influent distribution method changed in each of the two years. Pond cell was not monitored throughout the second year due to a reduction in resources. FWS \#2 remained the same for both years of the study and, the influent and effluent positions did not change. As a result of the similar flow conditions in each year, the concentration profiles from the two years were also very similar. The main difference between the two years was that the measured concentrations were lower in the second year. The influent wastewater to the lagoon was lower in constituent concentrations in the second year. which could account for the lower concentrations throughout FWS \#2, this could be due to more precipitation and runoff during the second year. 
The sediment zone of FWS \#2 demonstrated no significant trend in concentration throughout the cell with respect to TP (Figure 4.39), ammonia (Figure 4.40), nitrate (Figure 4.41) or TKN (Figure 4.42).

INLET

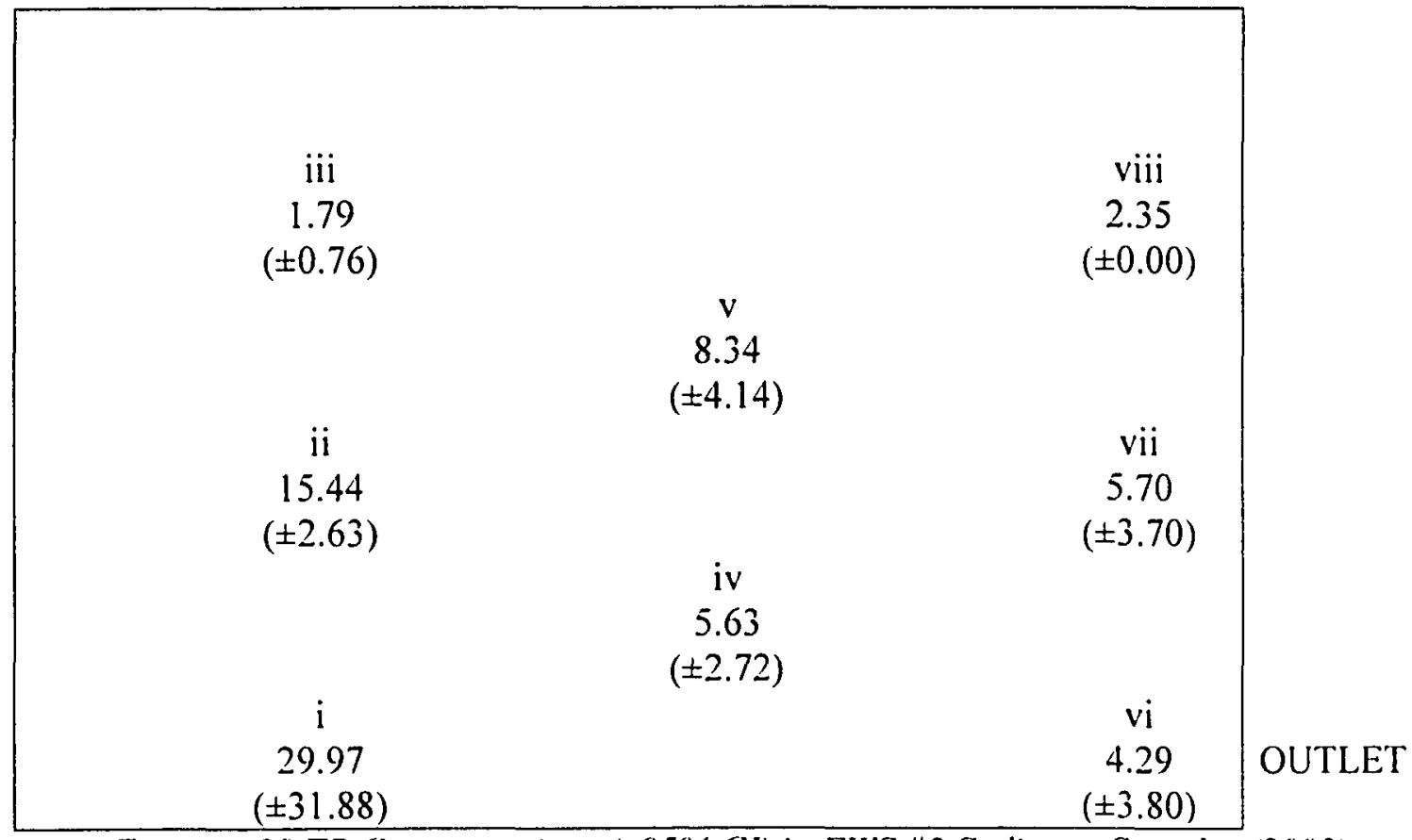

Figure 4.39 TP Concentrations ( $\pm 95 \%$ CI) in FWS \#2 Sediment Samples (2003) INLET

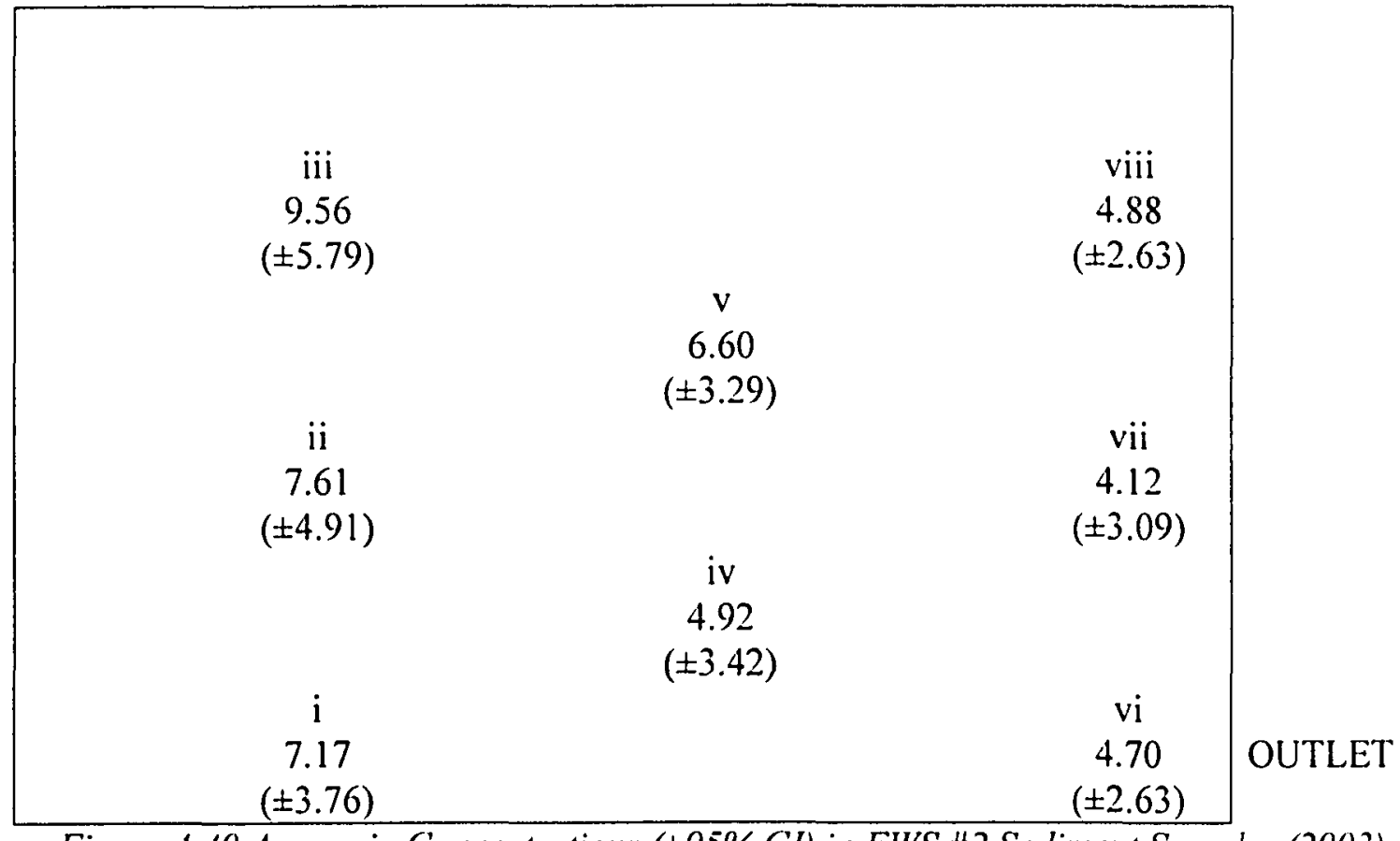

Figure 4.40 Ammonia Concentrations ( $\pm 95 \%$ CI) in FWS \#2 Sediment Samples (2003) 


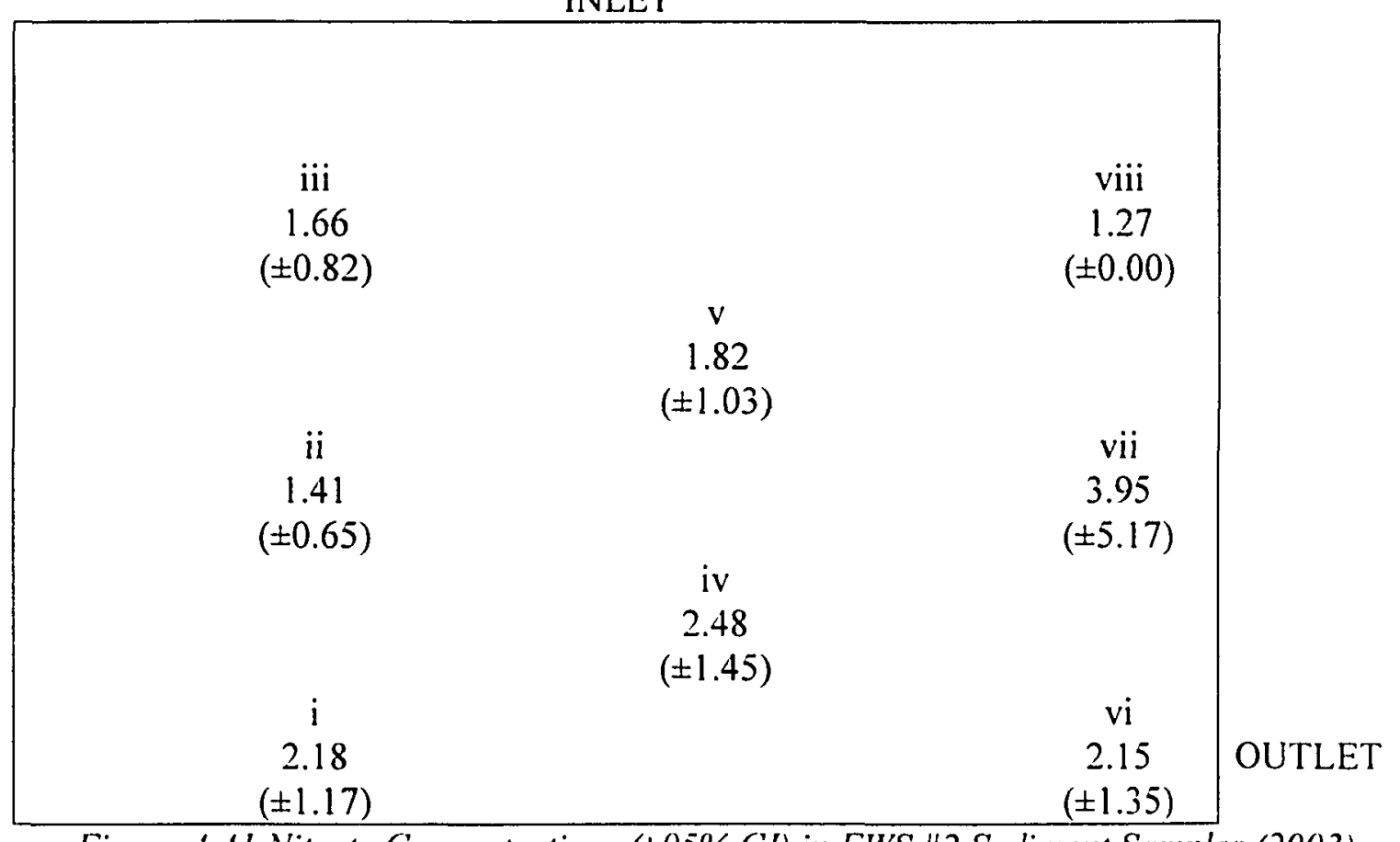

Figure +.41 Nitrate Concentrations ( $\pm 95 \%$ CI) in FWS \#2 Sediment Samples (2003)

INLET

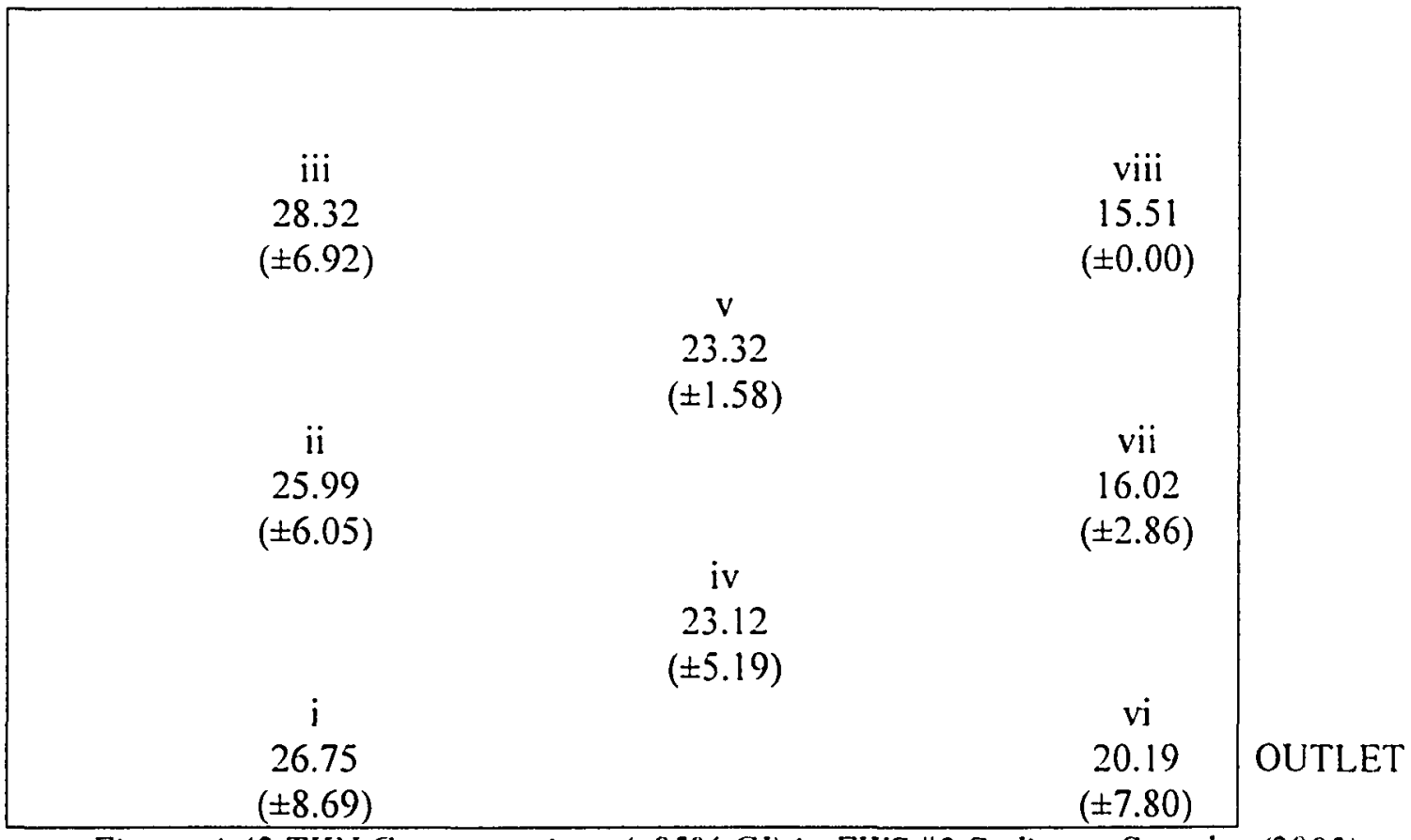

Figure 4.42 TKN Concentrations ( $\pm 95 \%$ CI) in FWS \#2 Sediment Samples (2003) 
The trends in average nutrient concentrations, or lack there of, within the wetland cells are similar to that of a completely mixed system, in that the composition is uniform throughout the entire wetland cell, the accounting may be made of the wetland cell as a whole (Levenspiel, 1999). Although there is little trend of progressive treatment within each of the wetland cells after nine years of operation, there is progressive treatment through the entire wetland system. This indicates that the wetland cells could be behaving as CSTRs, with the vegetation likely aiding in mixing.

Another option for the reason the concentrations within the cells are similar could be that the cells have reached background concentration levels. The reduction in treatment ability of the wetland during maturation might be a result of the increase in background concentration of the wetland throughout the maturation of the system.

\subsection{SEDIMENT DEPTH AND VEGETATION DENSITY IN FWS \#1}

After nine years of operation, the mature wetland was exhibiting some interesting phenomena with respect to the distribution of constituent concentrations. The TP concentrations throughout the wetlands have started to reach a steady state with respect to removal of phosphorous.

Mechanisms for the removal of suspended solids are sedimentation and filtration by the wetland plant media. These sediments accumulate, as the wetland matures, along the floor of the wetland cell and will remain there until dredging of the wetland takes place. FWS \#1 receives the highest concentrations of suspended particles and would. therefore, be the first cell that would require the dredging of sediments. At the beginning of the second year of sampling (2004), after the wetland had been operating for nine years, the sediments in the first cell were measured and a simple map of the sediment 
depth in FWS \#1 was produced (Figure 4.43). The map demonstrates that there are three regions (darkest) where the sediments peaked above the water surface $(30 \mathrm{~cm})$. There was also a trend of high sediments along the northern bank of the cell, while the middle and southern bank had lower sediment depths. The separation between the high-depth northern side and the low-depth southern side followed much the same path as would have been expected for the flow from the inlet header to the southern point along the outlet. This trend is seen in the tracer distribution in 2004 (Figure 4.4). Having lower sediment depths through one area and higher depth at another would suggest that preferential pathways and potential localized mixing zones have been established within the cell. Sedimentation occurs at a greater rate as flow velocities decrease; and the higher volumes of sediments are indicative of a lower velocity of flow in those areas. The lower sediment depths indicate higher flow velocities in these regions and, therefore, less sedimentation.

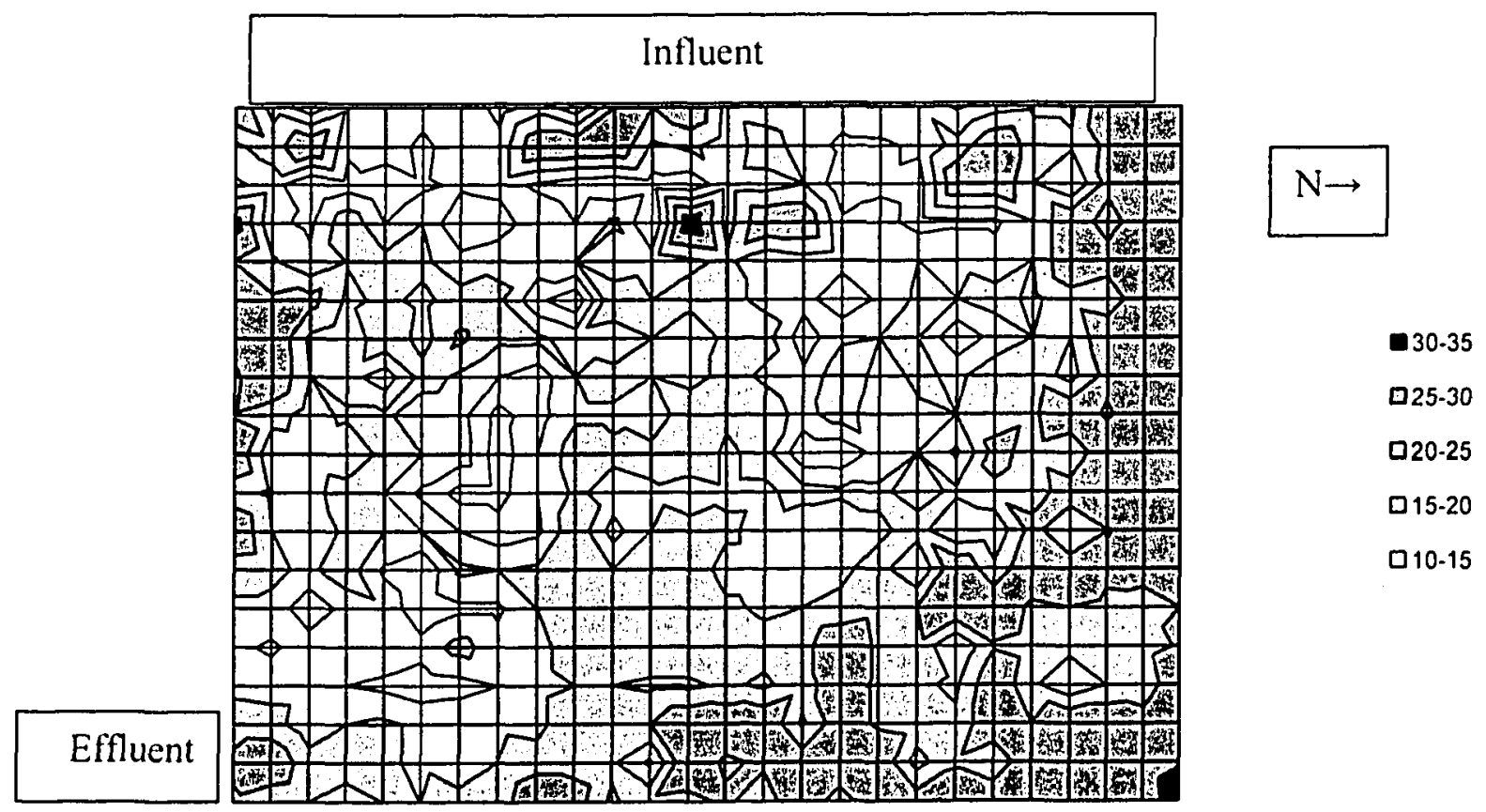

Figure 4.43 Sediment Height (in cm) Within FWS \#I (2004) 
Within the assumed preferred flow channel or areas of lower sediment depths, small peaks of deposited sediments and larger localized valleys of lower sedimentation were observed. If the flow were assumed to be moving uniformly through the flow area of the cell and the wastewater were assumed to have a uniform distribution of solids, the sedimentation of solids would be assumed to be uniform through the flow area. These localized peaks and valleys in the sediments can probably be attributed to the filtration of the wastewater by the wetland plants. When Figure 4.43 is compared with Figure 4.44 , the peaks and valleys of the sediments can often be found to correspond to the density of vegetation in those areas.

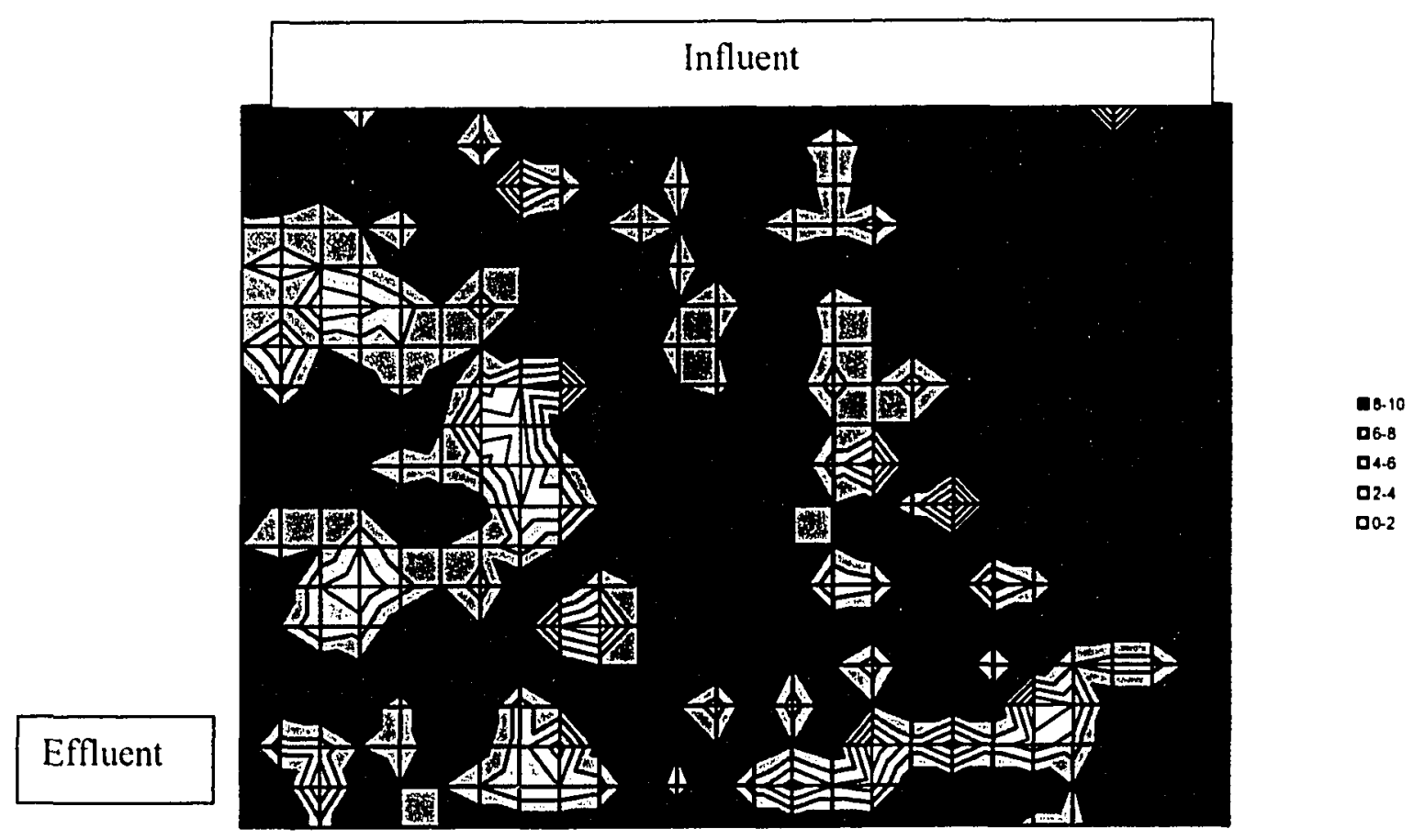

Figure 4.4 Vegetation density (out of 10) in FWS \#I (2004)

The low sediment depth regions that can be seen in Figure 4.43 typically correspond to areas of low vegetation density (Figure 4.44). Increased flow velocity over the sediments leads to re-suspension of some of the smaller and less dense sediments as 
well. This would account for the variability in TSS concentrations through the wetland cell. Dredging of the wetland could solve this variability problem, and since the vegetation would require re-planting after the dredging is complete, this new vegetation and the associated new soil layer would increase the potential for the removal of phosphorous. The removal of the vegetation from the cell would also remove the decaying vegetation that releases phosphorous into the system. Thus, the fresh cell would act as a new wetland with respect to the removal of wastewater constituents. However, the areas of increased and decreased flow velocities can also lead to zones of higher mixing intensities, which could help establish completely mixed conditions within the wetland cell.

The sediment distribution demonstrates the potential for localized mixing zones. As the wetland matures, the mixing zones will increase in size and number, as preferential flow pathways increase. These mixing zones will likely impact the entire system, given enough time to evolve, resulting in a complete mixing of the system. This is probably why there are similar concentrations throughout each wetland cell. This mixing within the cells can create a situation where the cells are acting as if they were a completely mixed system.

Since the rates of conversion are greater under plug flow characteristics than under mixed flow characteristics, the reactions will be completed more quickly under plug flow, and therefore plug flow treatment systems would require a smaller volume than mixed flow systems. When the conversion of a constituent is small, flow type only affects the performance slightly, but as the conversion of the constituent increases, the size ratio increases rapidly (Levenspiel, 1999). As the wetland matures, there appears to 
be a transition in the flow type, from a plug flow system, which represents the original system design, to a mixed flow system. This change in flow characteristics could possibly be correlated to sedimentation and vegetation growth. When the wind rustles the vegetation, the stalks transfer the motion, thus mixing the wastewater. Increased sediment depths decrease the volume of wastewater flow, thus increasing the flow velocity, which also adds to the mixing of the wastewater within the cell. Dredging the wetland to remove the sediments and vegetation. followed by replanting of the cell, would lower the sediment depths, thus decreasing the flow velocities. Replanting the cell with a lower density of vegetation would result in less mixing due to an increase in space between the stalks.

\subsection{ASSESSMENT OF DESIGN MIODELS}

The analysis of the influent and effluent constituent concentrations from the cells and the comparison to the three existing design models (Kadlec and Knight, 1996; Reed et al., 1995; and Crites and Tchobanoglous, 1998) for constructed wetlands resulted in some significant discrepancies. The calculated rate constants for the nutrients (Table 4.3) did not reflect the values suggest in the literature (DLWC, 1998; CH2M Hill, 1997). For the majority of the cells, the suggested values were higher than the values determined from the Dignard wetland concentrations. All of the rate constants were lower in the wetland than suggested in the literature. 
Table 4.3 Calculated Rate Constants Compared to Values from the Literature TP $\mathrm{BOD}_{5}$ Ammonia Nitrates TKN

\begin{tabular}{|c|c|c|c|c|c|c|}
\hline \multirow{5}{*}{ 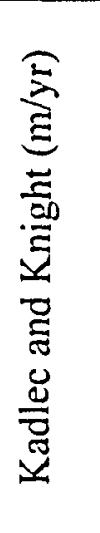 } & FWS \#1 2003 & 3.12 & 5.66 & 7.49 & 5.53 & 3.29 \\
\hline & FWS \#1 2004 & 3.255 & 10.6 & 2.1 & 0 & -- \\
\hline & FWS \#2 2003 & 2.035 & 2.67 & 11.48 & -0.4 & 2.31 \\
\hline & FWS \#2 2004 & 0.355 & -0.546 & 12.18 & -0.52 & $\cdots$ \\
\hline & $\begin{array}{c}\text { Literature } \\
\text { values }(\mathrm{CH} 2 \mathrm{M} \\
\text { Hill, 1997) }\end{array}$ & 8 & 22 & 10 & $\cdots$ & 14 \\
\hline \multirow{5}{*}{ 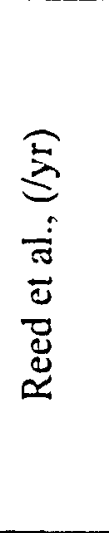 } & FWS \#1 2003 & -- & 19 & 24.17 & 19.43 & -- \\
\hline & FWS \#1 2004 & --- & 0.28 & $\cdots$ & 0.137 & $\cdots$ \\
\hline & FWS \#2 2003 & $\cdots$ & 0.021 & 0.112 & -0.01 & -- \\
\hline & FWS \#2 2004 & -- & -0.004 & -- & -0.005 & -- \\
\hline & $\begin{array}{c}\text { Literature } \\
\text { values (DLWC, } \\
\text { 1998) }\end{array}$ & -- & 0.296 & 1.048 & 1.15 & $\cdots$ \\
\hline \multirow{5}{*}{ 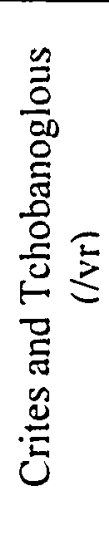 } & FWS \#1 2003 & $\cdots$ & 7.56 & $\cdots$ & -- & --- \\
\hline & FWS \#1 2004 & $\cdots$ & 0.095 & -- & --- & -- \\
\hline & FWS \#2 2003 & $\cdots$ & 0.022 & --- & -- & --- \\
\hline & FWS \#2 2004 & --- & -0.004 & $\cdots$ & --- & --- \\
\hline & $\begin{array}{c}\text { Literature } \\
\text { values (DLWC, } \\
\text { 1998) }\end{array}$ & --- & 0.296 & -- & -- & -- \\
\hline
\end{tabular}

The difference between the actual values and the literature values indicated that the wetland was not behaving as the models would predict. The Kadlec and Knight, and Reed, Crites and Middlebrooks models both assume plug flow characteristics, which, as discussed previously, are more efficient than mixed flow characteristics. The Crites and 
Tchobanoglous model assumes that the flow within the wetland acts as a series of 4 CSTR's, which result in a more efficient system than a single CSTR, but less efficiently than a plug flow system. Since each of the cells of the Dignard constructed wetland appeared to be behaving like single CSTRs, then it would be anticipated that the wetland cells would be less effective than the models would estimate. The tracer data from Section 4.1 also demonstrated that the wetland was not operating under ideal flow conditions (plug flow with respect to Kadlec and Knight and Reed Crites and Middlebrooks models, mixed reactors in series with respect to the Crites and Tchobanoglous model), which may be one of the causes for the differences in the results.

To better understand how the wetland was behaving differently than the design models, the concentrations at each of the points were analyzed with respect to the models. This analysis better demonstrated the areas within the wetland that behaved as the models predicted, as well as indicated which of the models, that are each based upon different assumptions and criteria, best represent the Dignard wetland treating agricultural wastewaters in the climate of eastern Ontario, Canada.

When the wetland cells were divided into different zones, separated by the retention time of the tracer, some of the models were applicable for different regions of the cell. In order to analyze the concentration distribution throughout the cell with respect to the models, the FWS \#1 influent concentrations measured in the first year could not be used. Instead, the influent concentration was estimated due to changes in the inlet, as was discussed in Section 4.2.1. This assumption allowed for the model to be analyzed for its pertinence at the other points within the cell. The model calculations can be found in Appendix D. 


\subsubsection{TSS Removal}

Modeling the TSS removal through the cells did not result in any comparable results of the collected data to the existing models. During the first year of the study (2003), the concentrations varied significantly from sampling session to sampling session and could not be reproduced with model predictions. In the second year of the study (2004), the concentrations were very high at the influent and the actual concentrations within the cell were below the predicted background level, which would indicate that the background concentration calculations from the Kadlec and Knight model were too conservative for the concentrations observed in the Dignard wetland. For this system configuration, the Kadlec and Knight model also results in a drop in TSS values to the background level within one day, which would indicate that the removal of TSS would only occur in the first day of treatment.

\subsubsection{TP Removal}

The removal of TP within the wetland cells could also not be represented adequately by any of the models, due to the pseudo-steady state conditions that were reached in the Dignard wetland with respect to the treatment of phosphorous. The models assume that there is a high concentration zone within the sediment for the sorption of phosphorous. However, the models do not account for the exhaustion of these sorption sites in a mature wetland which would greatly decrease the ability of the wetland cell to remove phosphorous without dredging, harvesting and re-vegetating of the wetland cell

\subsubsection{Ammonia Removal}

The ammonia removal throughout the cells of the Dignard wetland was extremely efficient. In most cases, the removal of ammonia was higher than the models predicted 
with shorter residence times ( $<5$ days), and the models predicted better removals at higher retention times. In FWS \#1, during the first year of the study (with adjusted influent concentrations), a model containing two CSTRs in series (Figure 4.45) resulted in a good fit to the lower concentrations in the cell (using the rate constant suggested for the Reed model; Table 4.3). In the first cell during the second year of the study (Figure 4.46), the Kadlec and Knight model predicted the concentrations well at the higher retention times.

The Reed, Crites and Middlebrooks model utilizes the influent TKN concentration to determine the effluent ammonia concentration and, thus the rate of denitrification. The other two models use influent ammonia concentrations to determine the effluent ammonia concentrations. For this reason, the initial concentrations on the following figures are different for the two models.

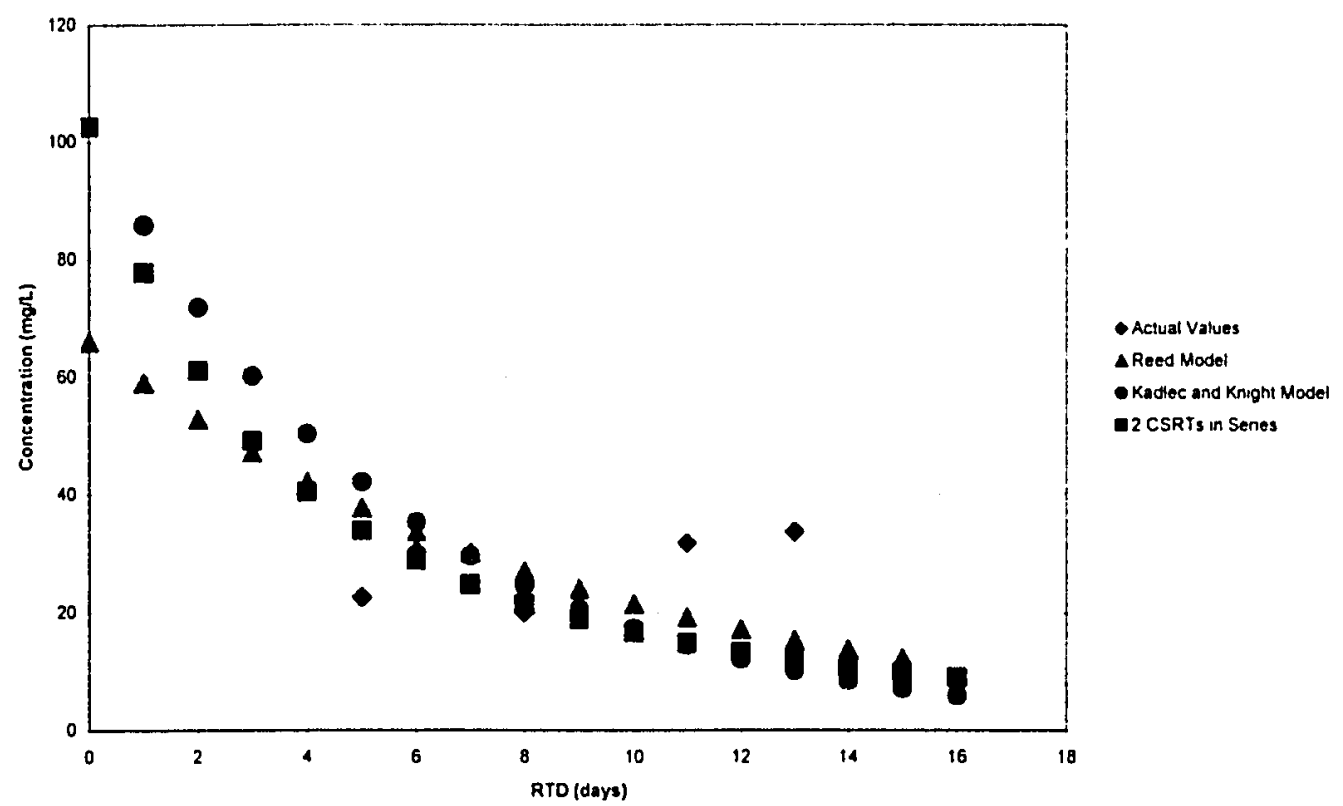

Figure 4.45 Ammonia Concentrations in FWS \#1 (2003) 


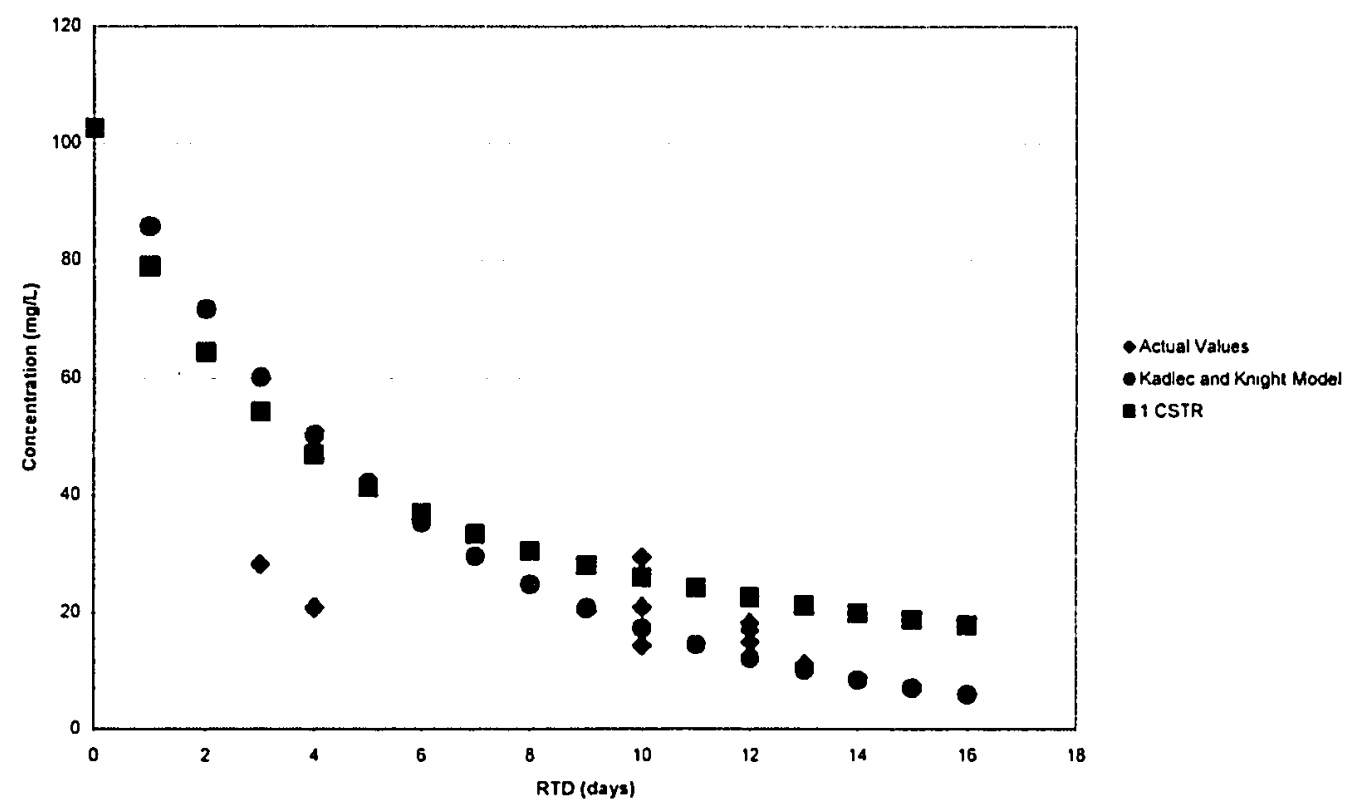

Figure t. 46 Ammonia Concentrations in FWS \#1 (2004)

In FWS \#2, during the first year, the ammonia concentrations were lower than the Reed model predicted (Figure 4.47), but if the rate constant were considered to be a higher value than suggested, the model would provide a good fit to the points within the cell at longer retention times. The Kadlec and Knight model predicted the concentrations at the points with a shorter retention time. The FWS \#2 concentration distribution observed in 2004 was far lower than any of the models predicted, and no relations to the models could be observed (Appendix D). 


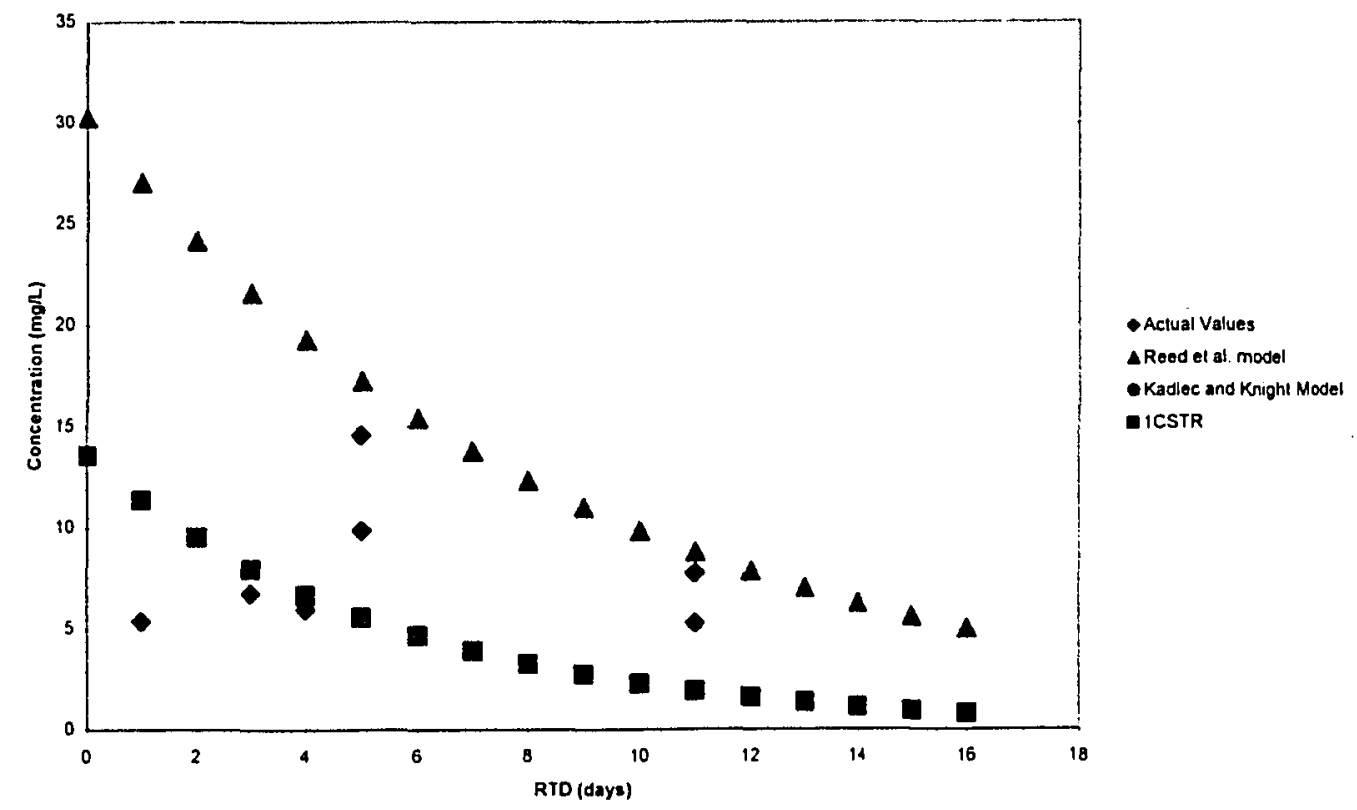

Figure 4. 47 Ammonia Concentrations in FWS \#2(2003)

\subsubsection{Nitrate Removal}

Since the nitrate concentrations through the cells were consistently low, the models did not accurately describe the removal of nitrates. All of the models predicted that the nitrate concentrations would be reduced to a value lower than concentrations measured in the cells.

\subsubsection{TKN Removal}

The TKN concentrations through the cells demonstrated no correlation in trend or magnitude with the concentrations predicted by the models. Therefore no appropriate fit could be made to any of the models. The Models for TKN removal are presented in Appendix D.

\subsection{6 $\mathrm{BOD}_{5}$ Removal}

The Crites and Tchobanoglous model (4 CSTRs in series for the removal of $\mathrm{BOD}_{5}$ ) predicted well the processes at work in the earlier portions of the cell where the 
retention time was less than four days, after 4 days the model did not adequately describe the removal of $\mathrm{BOD}_{5}$. The Kadlec and Knight and Reed (plug flow) models also worked well for the removal of $\mathrm{BOD}_{5}$ at a retention time of less than four days.

The models for the design of wetlands may not be applicable to the treatment of wastewater constituents in mature constructed wetlands. As the wetlands mature, the treatment efficiencies decrease with respect to some of the constituents, TSS and TP especially. The flow and treatment dynamics would also be expected to change; uneven sedimentation increases the flow rate and creates flow channels. The mixing induced by these changes in flow, as well as the increased vegetation density creates a treatment dynamic that is more like a single CSTR than a plug flow. The existing models are based on a large database of young wetlands, acting under plug flow conditions, with little to no mature systems. New models need to be developed to better describe the activities within mature systems. These models would need to track the change from the plug flow dynamic to the completely mixed scenario that is observed in the Dignard constructed wetland.

\subsection{ENGINEERING SIGNIFICANCE}

As wetland systems mature, many changes take place that alter the efficiency and method of treatment. When the wetland is first built, the vegetation is uniformly planted, and the types of species are controlled. The soil at the base of the wetland cells has sorption sites that are available to adsorb phosphorous. There are no sediments from the wastewater that cover the floor of the cell. The bacterial cultures in the water are immature, and there are no insect larvae in the cells. As the wetland matures, all of these conditions change. The vegetation in the cells propagates naturally, which results in an 
uneven density of vegetation and different species of vegetation entering the cell. This increased vegetation density results in a larger surface area for bacterial growth, which is good, but also blocks more sunlight and wind driven aeration of the wastewater, which can affect the treatment within the cells. The phosphorous sorption sites begin to become depleted and the removal of phosphorous is decreased. Sediments begin to accumulate on the floor of the wetland cells, further blocking phosphorous sorption to the soils as well as potentially creating flow channels. The sediments also give media for the growth of different bacteria in the system. Bacteria cultures mature along with the wetland. which increases the biological treatment potential of the system.

The tracer concentration distribution and the concentration distribution in each of the cells seemed to indicate that the system was behaving like a completely mixed reactor. This is in opposition to the accepted thought that the wetlands behave as plug flow reactors. However, most of the wetlands that were studied to create the models were young systems (2-3 years old), and the system that was studied was a mature system ( 9 years old). The kinetic rate constants that were determined for each of the cells of the wetland were different then the rate constants suggested for any of the design models.

Without adequate monitoring of the data from the first year of the wetland operation, it is impossible to know if the wetland originally functioned as a plug flow reactor, and therefore if the dynamics of the system have really changed. Another option would be that the treatment within the cells was quickly reducing the constituent concentrations to background levels, and it is these background levels that are increasing as the wetland matures. 


\section{CHAPTER 5 CONCLUSIONS AND RECOMMENDATIONS}

\subsection{CONCLUSIONS}

With the new environmental regulations that are coming into place in Ontario, adequate treatment of agricultural wastewaters must be ensured. Since farmers will have to fund their own onsite treatment systems, as well as any monitoring costs, the system with the least capital and, maintenance and operation costs will be preferred. Constructed wetlands offer a wastewater treatment option that requires minimal construction costs and limited operation and maintenance. The wetland cells will need to be occasionally cleaned (sediments removed and vegetation replanted). From the results of this study, a mature wetland which receives a high organic load wastewater similar to that of the Dignard operation will need to be dredged within approximately eight years of operation. With the field machinery available to a farmer, this should not be a difficult and costly undertaking. Since most conventional wastewater treatment systems are designed for a useful life of twenty years, wetland treatment systems need to demonstrate an equivalent expected lifetime. With occasional dredging and replanting of the wetland cells, the life of the wetland could be extended indefinitely. Increased wastewater flows can also be treated by adding more treatment steps (anacrobic lagoons, facultative ponds or marshpond-marsh wetland cells) to the systems.

Observing the activities within the individual cells of a wetland is essential in determining the treatment processes and efficiencies within the wetland system. Analyses of the wetland influents and the effluents will not provide sufficient information to enhance the understanding of these processes. Ideal treatment processes within the wetland require the flow through the wetland to be uniform, which is an unrealistic 
assumption in a natural and dynamic system, since there are various factors affecting the flow such as vegetation density, uneven settling, and wind induced turbulence. Dissecting the wetland cells allows for the assessment of the sections of the cells that are useful in the treatment of wastewater constituents, and those that are not. These observations, in turn, can lead to a better understanding and, ultimately, better design of wetland sizing and the prediction of treatment potential.

The tracer study throughout the cells indicated that the flow generally followed the path that would be expected based on the inlet and outlet positions. These flow patterns (CSTR) are not ideal (plug flow) for the treatment of wastewater constituents in a wetland. To improve the flow pattern, and maximize contact with the entire wetland. the outlet conditions should be modified. The flow can be improved by changing the outlet from a point along one of the sides to a series of weirs along the outlet end of the cell, which would induce a sheet flow dynamic over the entire cell. This would better distribute the wastewater stream, which would reduce the number of dead zones within the cell. The reduction of dead zones would mean that preferential flow pathways within the cell would be the only inhibitors to sheet flow dynamics. which would be ideal in wetland design.

The tracer flow through the wetland was useful in explaining the abnormal concentrations within the zones of the wetland that received small amounts of tracer, but the flow path of the tracer could not be correlated to any specific removal pattern within the cell. The tracer distribution and movement throughout the wetland cell did not correlate with the distribution of concentration throughout the cell, which might suggest that the wetland was likely acting as a completely mixed system or has reached 
background concentrations. The instantaneous addition of the tracer solution was effective at illustrating the mixing profile within the wetland cells. However, the injection of the tracer solution continuously with the flow of wastewater being added to the wetland system, may be more effective at further defining the mixing profile within the cells. The tracer distribution was also able to support the sedimentation patterns within FWS \#1, with respect to the high sedimentation pattern in the lower flow region.

For all of the constituents, in both years of the study, the concentration reduction reached a plateau within the first eight days of flow through the cells. which is when the Kadlec and Knight model demonstrated the best correlation to the actual removal efficiency of the cells. The aerial based Kadlec and Knight design model works best at lower retention times, but the treatment efficiency of the cell generally decreases faster than that expected in the model. The Reed, Crites and Middlebrooks model accounts for the tapering off of treatment efficiency through the cell, but the model is too conservative, for the most part, with respect to the treatment within the first section of the cell. Both the Kadlec and Knight model and the Reed, Crites and Middlebrooks model can be compared with the treatment ability of the Dignard wetland cells, but the rate constants suggested by the literature needed to be altered.

The design models for wetland treatment, which are based on young treatment systems, did not appear to apply to this mature wetland. Designs should ensure sustainability of the wetland treatment systems. New models, which account for the reduction in treatment as the wetland matures, must be developed to ensure that adequate prediction of the wastewater treatment within the system is possible. As a constructed wetland matures, the efficiency for treating wastewater constituents decreases; this may 
be the result of the change from a plug flow treatment system to a CSTR treatment system, or the increase in the background concentration of the system.

The concentration distribution at each of the sampling points varied throughout the two years of the study. This variance in constituent concentrations was a result of the weather in the region. In the spring and fall, the rain dilutes the wastewater, resulting in lower concentrations, where as in the summer, high evapotranspiration results in more concentrated wastewater.

\subsection{RECOMMENDATIONS FOR FURTHER STUDY}

There are several studies that could be performed to better understand the processes within a matured constructed wetland. The results from the tracer study presented in this thesis could be further analyzed with sophisticated computer modeling approaches to take into account dynamic factors such as sedimentation, mixing intensities, possible changing flow regimes, vegetation growth. etc. This type of analysis would generate a better understanding of the actual treatment performance and the dynamics of various factors within the wetland cells. This could then lead to the development of specific model predictions of the treatment performance occurring within mature wetlands.

A study of the hydrodynamic flow and treatment performance throughout the loose sediments of the wetland cells, correlated with the hydrodynamic flow and treatment performance of the surface water may lead to the understanding of which portion of the wetland mediates the treatment of the individual constituents. This could lead to the development of specific rate constants with changing sediment volumes and characteristics. That is, as the wetland matures there is a greater build-up of sediments on 
the wetland floor and a greater opportunity of surface water and loose sediment water to interact, and impact overall wetland treatment performance.

Further studies on maturing constructed wetlands are required as the treatment efficiency and flow patterns appear to change significantly throughout the life of the wetland. This would help to generate specific models that will better describe the treatment potential of the wetland system, as well as assist in the determination of important design considerations such as dredging of sediments and, harvesting and replanting of vegetation, as the system ages. 


\section{CHAPTER 6 \\ REFERENCES}

(APHA) American Public Health Association, American Water Works Association and Water Pollution Control Federation, "Standard Methods for the Examination of Water and Wastewater $20^{\text {th }}$ Edition" American Public Health Association, Washington, D.C., 1998

Bedient, P.B., Rifai, H.S., Newell, C.J., 1994 "Ground Water Contamination- Transport and Remediation, Prentice Hall

Begg, J S; Lavigne, R L; Venemann, P L M, 2001 "Subsurface Flow Wetland Systems Reed Beds: Constructed Wetlands for Municipal Waste Water Treatment Plant Sludge Dewatering: Water Science and Technology, Vol. 44, N. 11-12, P. 393

Bowmer, K.H., 1987 "Nutrient Removal from Effluents by an Artificial Wetland: Influence of Rhizosphere Aeration and Preferential Flow Studied using Bromide and Dye Tracers" Water Resources, Vol. 21, N. 5, P. 591

Brooks, Joan Lake, 1988 "The Role of Fungi in the Sphagnum Peat Wastewater Treatment System"

CH2M Hill, Payne Engineering, 1997. "Constructed Wetlands for Animal Waste

Trealment - A Manual on Performance, Design, and Operation with Case Histories" Gulf of Mexico Program - Nutrient Enrichment Committee, 1997

Chazarence. F.; Merlin, G.; Gonthier, Y., 2003 "Hydrodynamics of Horizontal Subsurface Flow Constructed Wetlands" Ecological Engineering, Vol. 21, Issue 2-3. P. 156

Crites, R.; Tchobanoglous, G., 1998, Small and Decentralized Wastewater Treatment Systems, McGraw-Hill, Boston. MA, USA

Crolla, A.; Kinsley, C.,2002 "Use of Kinetic Models to Evaluate the Performance of a Free Water Surface Constructed Wetland Treating Farmstead Runoff' $\delta^{\text {th }}$ International Conference on Wetland Systems, Vol. 2

DLWC (Department of Land and Water Conservation), 1998, The Constructed Wetlands Manual, Vols $1 \& 2$, New South Wales. Australia

Drizo, A.; Ross, D.; Lewis, T.; Munoz, P.; Bird, S., 2004, "Constructed Wetlands for Agricultural Effluent Treatment at the University of Vermont: First six months of Operation" 9 th International Conference on Wetland Systems 
Ferguson, R.B.; D.E. Kissel; J.K. Koelliker; Basel, W., 1984. "Ammonia volatilization from surface-applied urea: Effect of hydrogen ion buffering capacity". Soil Science Society of America Journal, Vol. 48, P. 578

Hench, K R; Bissonette, G K; Sextone, A J; Coleman, J G; Garbutt, K E, 2003 "Fate of Physical, Chemical and Microbial Contaminants in Domestic Wastewater Following Treatment by Small Constructed Wetlands" Water Research, Vol. 37, N. 4, P. 921

Herskowitz, J, 1986 "Listowel Artificial Marsh Project. External Research Projects, Part B, Water Quality Research" Technology Transfer Conference: Proceedings

Hill, C. M.; Duxbury, J; Geohring. L; Peck, T. 2000 "Designing Constructed Wetlands to Remove Phosphorous from Barnyard Runoff: a Comparison of Four Alternatives"

Kadlec, R.H., 1994, "Detention Time and Mixing in Free Water Wetlands" Ecological Engineering, Vol. 3, P. 345

Kadlec, R.H.; Knight, R.L., 1996. Treatment Wetlands. CRC Press LLC, Boca Raton, Fla.

Kirby, A., 2002 "Wastewater Treatment Using Constructed Wetlands" Canadian Water Resources Journal Vol. 27, N. 3, P. 263

Laenen, A; Bencala, K.E., 2001 "Transient Storage Assessments of Dye-Tracer Injections in Rivers of the Willamette Basin. Oregon", Journal of the American Water Resources Association, Vol. 37, N. 2, P. 367

Levenspiel, O., 1999, Chemical Reaction Engineering, John Wiley \& Sons, Toronto, Canada

Lin, A.Y.; Debroux, J.F.; Cunnighman, J.A.; Reinhard, M., 2003 "Comparison of Rhodamine WT and Bromide in the Determination of Hydraulic Characteristics of Constructed Wetlands" Ecological Engineering, Vol. 20, Issue 1, P. 75

McKee, J.A.; Brooks, J. L.; 1994 "Experience with Peat Filters for On-Site Wastewater Treatment in Ontario" Wastewater Nutrient Removal Technologies and Onsite Management Districts, P. 72

Merlin, G; Pajean, J-L; Lissolo, T, 2002: Performances of constructed Wetlands for Municipal Wastewater Treatment in Rural Mountainous Area" Hydrobiologia, Vol. 469, P. 87

Pries, J; McGarry, P., 2002 "Feedlot Stormwater Runoff Treatment Using Constructed Wetlands" National Conference on Agricultural Nutrients and Their Impact on Rural Water Quality 
Rash, J.K.; Liehr, S.K., 1999 "Flow Pattern Analysis of Constructed Wetlands Treating Landfill Leachate" Water Science and Technology, Vol. 40, N. 3, P. 309

Reddy, G B; Hunt, P G; Phillips, R; Stone, K; Grubbs, A, 2001 "Agricultural Wastewater - Treatment of Swine Wastewater in Marsh-Pond-Marsh Constructed Wetlands" Water Science and Technology, Vol. 44, N. 11-12, P. 545

Reed.S; Crites, R; Middlebrooks, J, 1995 Natural Systems for Wastewater Management and Treatment, $2^{\text {nd }}$ Edition, Mcgraw-Hill

Revitt, D M; Worrall, P; Brewer, D, 2001 "Industrial Wastewaters - The Integration of Constructed Wetlands into a Treatment System for Airport Runoff" Water Science and Technology, Vol. 44, N. 11-12, P. 469

Robson, B, 1999 "Nutrient Management Issues: Canadian Perspective" Proceedings from the Nutrient Management Planning Conference, P.41

Schmid, B.H.; Hengl. M.A.; Stephan, U., 2004 "Salt Tracer Experiments in Constructed Wetland Ponds with emergent Vegetation: Laboratory Study on the Formation of Density Layers and its Influence on Breakthrough Curve Analysis" Water Research, Vol. 38, Issue 8, P. 2095

Simi, A.L.; Mitchell, C.A., 1999. "Design and Hydraulic Performance of a Constructed Wetland Treating Oil Refinery Wastewater" Water Science and Technology, Vol. 40, N. 3, P. 301

Thurston-Enriquez, J.; Henry, C.; Eghball, B., 2004, "Constructed Wetlands for the Reduction of Manure-borne Fecal Indicators and Pathogenic Microorganisms from Dairy Cattle Wastewater" $9^{\text {th }}$ International Conference on Welland Systems

Vanderbrought. J; Vereecken, H. 2001 "Analysis of Locally Measured Bromide Breakthrough Curves from a Natural Gradient Tracer Experiment at Krauthausen", Journal of Contaminant Hydrology, Vol. 48, N. 1-2, P. 23

Watson, J.T. and J.A. Hobson; 1991; "Hydraulic Design Considerations and Control Structures for Constructed Wetlands for Wastewater Treatment': $I^{\text {st }}$ International Conference for Constructed Wellands for Wastewater Treatment: Manicipal, Industrial, and Agricultural; D.A. Hammer Ed.; June 13-17 1991; Chattanooga, Tennessee

Wallace, S.D., 2003 Constructed Wetland Design Approaches in University Curriculum Development for Decentralized Wastewater Treatment Forest Lake MN, USA 
APPENDIX A RELATED IMAGES 


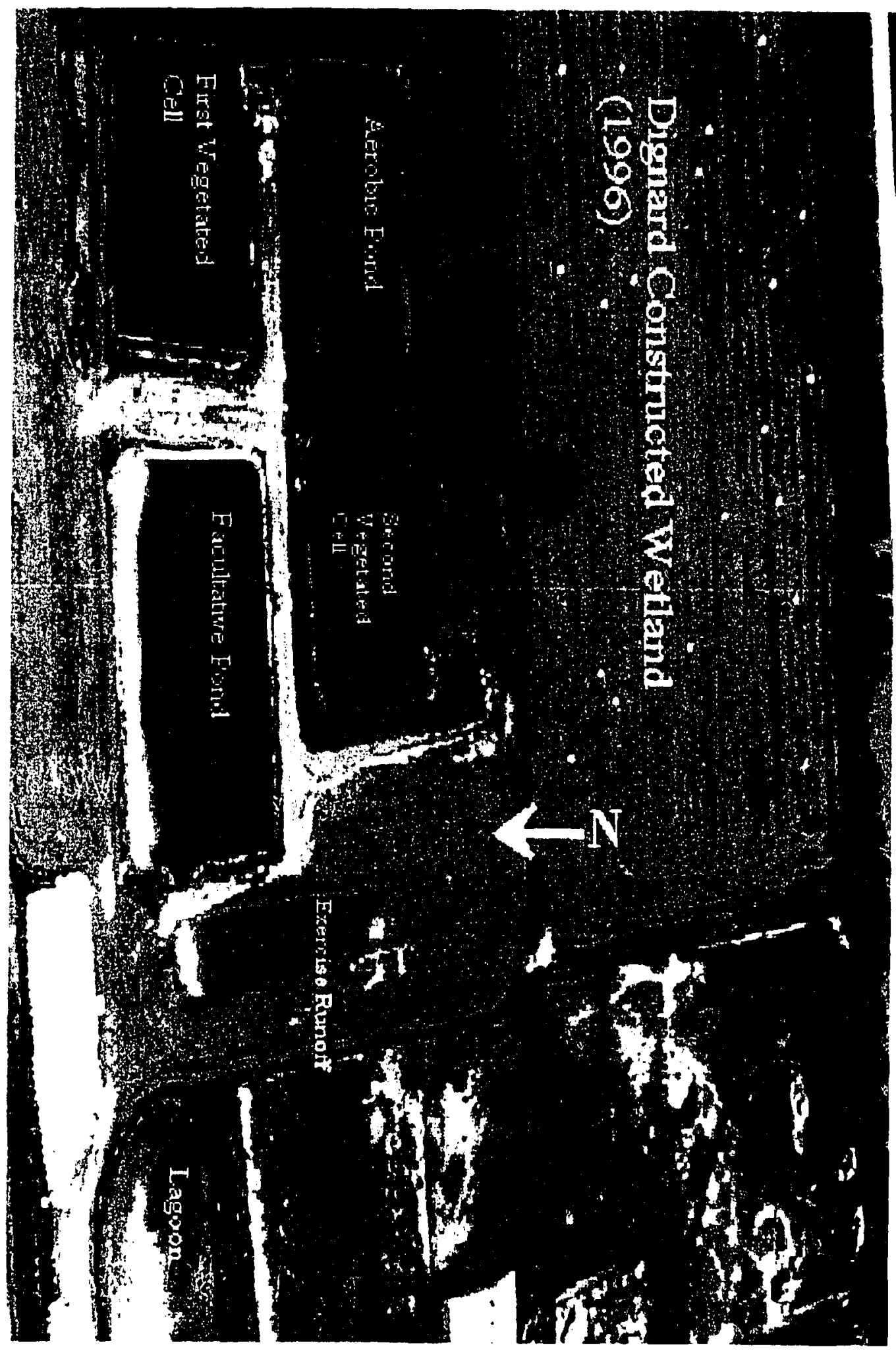

Figure A-I Aerial Photograph of Dignard Welland (1996) 


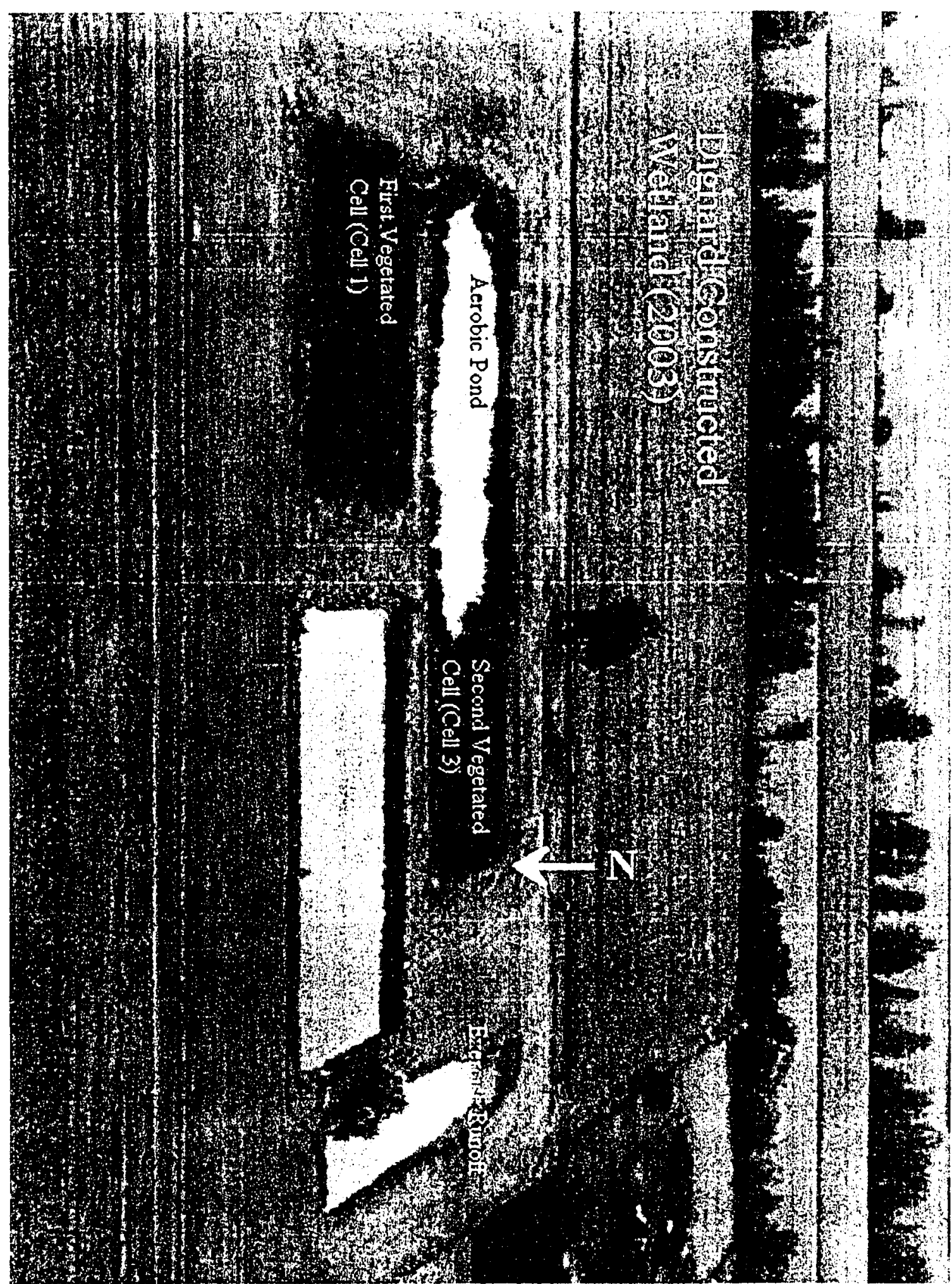

Figure A-2 Aerial Photograph of Dignard Welland (2003) 


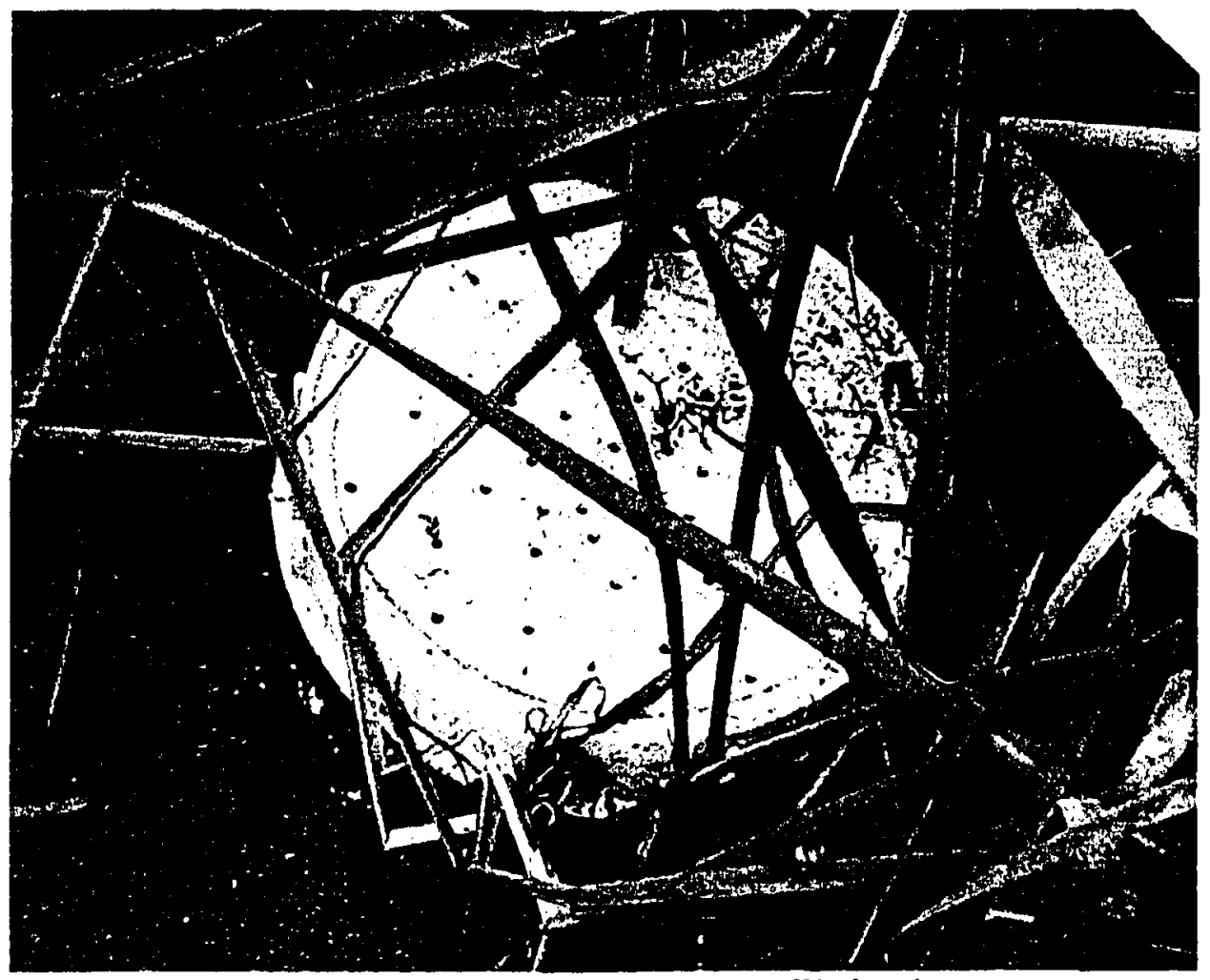

Figure A-3 Sieve Placement in Welland

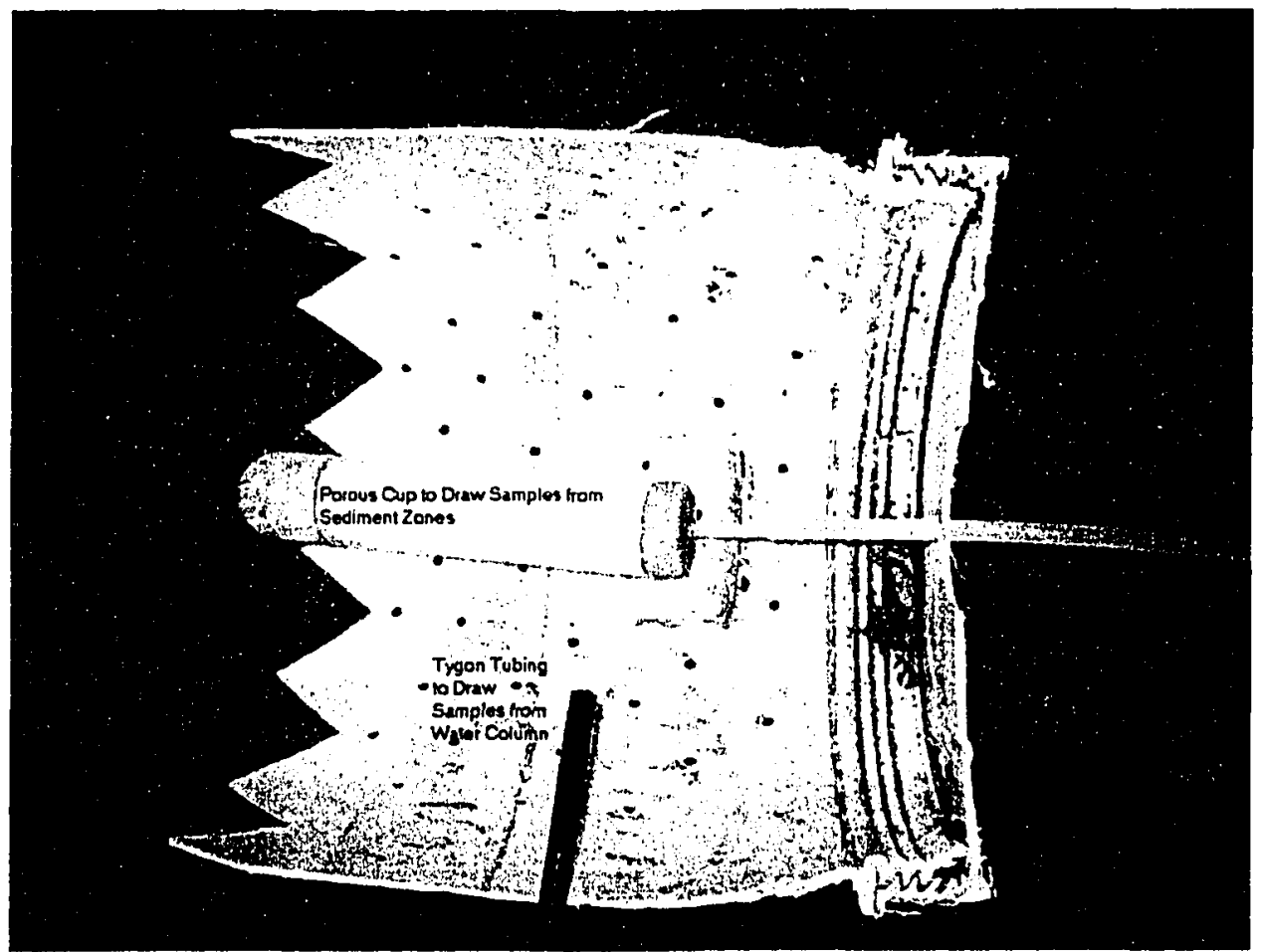

Figure A-4 Sampling Apparatus 


\section{APPENDIX B \\ RAW DATA}

121

Reproduced with permission of the copyright owner. Further reproduction prohibited without permission. 
Table B-1 Sample Temperatures (2003)

\begin{tabular}{|c|c|c|c|c|c|c|c|c|c|c|c|c|c|c|c|}
\hline 1910 & 1-May.03 & 4.Jun-03 & $17 . J u n-03$ & 2.Jut.03 & 15. Jut.03 & 29. Jut03 & 11.Aug.03 & 3] $26 \cdot A$ un.03 & 9.Sep-03] & $123.5 e p .03$ & $7.0 \mathrm{cc1.03/2}$ & 21.001 .03 & 4-Nov03 & Average & Sid Dov. \\
\hline & & & & & & & & & & & & & & & \\
\hline $\begin{array}{l}\text { Bgoon } \\
\text { xercise runotr } \\
\text { acullative Pond } \\
\text { ell } 1 \text { Infuent } \\
\text { ell } 2 \text { influent } \\
\text { ell } 3 \text { influent } \\
\text { ell } 3 \text { effuent } \\
\text { iner Strip Runont }\end{array}$ & $\begin{array}{r}17.3 \\
14.6 \\
15.3 \\
12.1 \\
10 \\
14 \\
11.1 \\
83 \\
\end{array}$ & \begin{tabular}{|r|} 
no sample \\
16.4 \\
18 \\
14.8 \\
10.8 \\
15.6 \\
16.0 \\
no sample
\end{tabular} & $\begin{array}{l}27.7 \\
24.4 \\
29.4 \\
21.9 \\
16.6 \\
196 \\
15.8 \\
16 \\
\end{array}$ & \begin{tabular}{|r|}
30.4 \\
24.8 \\
28.7 \\
22.1 \\
25 \\
24. \\
21.4 \\
no sample \\
\end{tabular} & $\begin{array}{r}25.1 \\
21.4 \\
24.6 \\
18.8 \\
18.1 \\
196 \\
\text { no sample } \\
\text { no sample } \\
\end{array}$ & $\begin{array}{r}34 \\
32 \\
27.8 \\
16.9 \\
18.1 \\
206 \\
186 \\
18 . \\
\end{array}$ & $\begin{array}{r}27.2 \\
\text { sample } \\
28.7 \\
221 \\
22 . \\
233 \\
21.1 \\
214 \\
\end{array}$ & \begin{tabular}{|r|}
20.1 \\
no sample \\
21.6 \\
no sample \\
no sample \\
23.1 \\
no sample \\
no sample
\end{tabular} & $\begin{array}{r}20.1 \\
\text { no sample } \\
13.1 \\
9.4 \\
10 \\
9.9 \\
\theta .2 \\
9.3 \\
\end{array}$ & \begin{tabular}{|r|}
19 \\
no sample \\
19 \\
19 \\
18.4 \\
18. \\
17.8 \\
17.7
\end{tabular} & \begin{tabular}{|r|} 
\\
no sample \\
5.5 \\
2.3 \\
2.6 \\
4.3 \\
2.6 \\
24 \\
\end{tabular} & $\begin{array}{r}8.7 \\
\text { no sample } \\
0.9 \\
9.7 \\
9.7 \\
9.5 \\
10.9 \\
11.7\end{array}$ & \begin{tabular}{|r|}
3.8 \\
no sample \\
4.2 \\
1.4 \\
2.9 \\
3.1 \\
2.5 \\
33
\end{tabular} & \begin{tabular}{|r|}
20.11668 \\
22.26667 \\
18.90769 \\
14.21667 \\
13.7 \\
1582308 \\
1326364 \\
11.87778
\end{tabular} & \begin{tabular}{|r|}
9.456007 \\
6.319072 \\
6.875047 \\
7.318946 \\
7.140155 \\
7.180663 \\
659792 \\
6.601852 \\
\end{tabular} \\
\hline & & & & & & & & & & & & & & & \\
\hline $\begin{array}{l}\text { Water } \\
\text { Sedimient } \\
\text { Waler } \\
\text { Sedrnent } \\
\text { Water } \\
\text { Sediment } \\
\text { Water } \\
\text { Sedment } \\
\text { Water } \\
\text { Sedrnent } \\
\text { Waler } \\
\text { Sedment } \\
\text { Water } \\
\text { Sedment } \\
\text { Waler } \\
\text { Sedment } \\
\text { Waler } \\
\text { Sedment }\end{array}$ & $\begin{array}{l}\text { no sample } \\
\text { no saimple } \\
\text { no sample } \\
\text { no sample } \\
\text { no sample } \\
\text { no sample } \\
\text { no sample } \\
\text { no sample } \\
\text { no sample } \\
\text { no sample } \\
\text { no sample } \\
\text { no sample } \\
\text { no sample } \\
\text { no sample } \\
\text { no sample } \\
\text { no sample } \\
\text { no sample } \\
\text { no sample }\end{array}$ & \begin{tabular}{|r|}
20.3 \\
no sample \\
22.4 \\
no sample \\
no sample \\
no sampse \\
21.3 \\
no sample \\
22.9 \\
no sample \\
22.4 \\
no sample \\
21.7 \\
no sample \\
19. \\
no sample \\
22.3 \\
no sample
\end{tabular} & \begin{tabular}{|r|}
24.3 \\
no sample \\
22.2 \\
no sample \\
22.7 \\
no sample \\
25.3 \\
no sampte \\
249 \\
no sampte \\
22. \\
no sampto \\
217 \\
no sample \\
20 \\
no sampte \\
210 \\
no sample
\end{tabular} & \begin{tabular}{|r|}
25.8 \\
no sample \\
28.2 \\
no sampie \\
27.8 \\
no sampie \\
298 \\
no sample \\
31.98 \\
no sample \\
316 \\
no sample \\
323 \\
no sample \\
298 \\
no sample \\
296 \\
no sample
\end{tabular} & $\begin{array}{r}194 \\
\text { no sample } \\
19 . \\
\text { no sample } \\
194 \\
\text { no sample } \\
197 \\
\text { no sample } \\
203 \\
n 0 \text { sample } \\
27 \\
\text { o sample } \\
236 \\
\text { no sample } \\
227 \\
\text { no sample } \\
\text { no ample } \\
\text { no sample }\end{array}$ & $\begin{array}{r}21.7 \\
23.8 \\
23.7 \\
242 \\
23.5 \\
256 \\
23.9 \\
26.1 \\
258 \\
25 \\
256 \\
231 \\
258 \\
24 \\
245 \\
248 \\
233 \\
251 \\
\end{array}$ & \begin{tabular}{|r|}
24 \\
246 \\
241 \\
no sample \\
245 \\
23.8 \\
25.5 \\
242 \\
258 \\
no samplic \\
26.3 \\
261 \\
265 \\
25 \\
286 \\
246 \\
265 \\
25 \\
\end{tabular} & $\mid$\begin{tabular}{|r|} 
no sample \\
18.5 \\
no sample \\
18 \\
18 \\
no sample \\
10 \\
no sample \\
no sample \\
no sample \\
18.9 \\
no sample \\
18.7 \\
no sample \\
180 \\
no sample \\
189 \\
no sample \\
180 \\
\end{tabular} & $\begin{array}{l}11.2 \\
16.1 \\
11.3 \\
15.8 \\
11.2 \\
15.6 \\
11 \\
156 \\
148 \\
15.5 \\
109 \\
146 \\
13.9 \\
14.3 \\
109 \\
14 . \\
132 \\
138 \\
13 .\end{array}$ & $\begin{array}{l}17.9 \\
20.7 \\
17.9 \\
207 \\
18.4 \\
208 \\
183 \\
208 \\
18.2 \\
209 \\
103 \\
209 \\
10.9 \\
208 \\
186 \\
207 \\
19 \\
20 . \\
\end{array}$ & 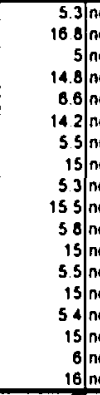 & $\begin{array}{l}\text { no sample } \\
\text { no sample } \\
\text { no sample } \\
\text { no sample } \\
\text { no sample } \\
\text { no sample } \\
\text { no sample } \\
\text { no sample } \\
\text { no sample } \\
\text { no sample } \\
\text { no sample } \\
\text { no sample } \\
\text { no sample } \\
\text { no sample } \\
\text { no sample } \\
\text { no sample } \\
\text { no sample } \\
\text { no sample }\end{array}$ & \begin{tabular}{|l|} 
no sample \\
no sample \\
no sample \\
no sample \\
no sample \\
no sample \\
no sample \\
no sample \\
no sample \\
no sample \\
no sample \\
no sample \\
no sample \\
no sample \\
no sample \\
no sample \\
no sample \\
no sample
\end{tabular} & 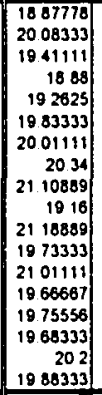 & $\begin{array}{r}6.69023 \\
3570688 \\
7.161701 \\
3.789605 \\
7.13341 \\
1.478244 \\
7.596289 \\
1981787 \\
7.734773 \\
399975 \\
8.23733 \\
4539897 \\
7.80856 \\
1464825 \\
7.624150 \\
1.584939 \\
7520258 \\
4646899 \\
\end{array}$ \\
\hline & & & & & $\mathcal{L}$ & & & & & & & 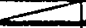 & & & \\
\hline $\begin{array}{l}\text { Water } \\
\text { I Sedwnent } \\
\text { II Water } \\
\text { II Sedrment } \\
\text { IIII Water } \\
\text { IIII Sediment } \\
\text { IV Water } \\
\text { V Water } \\
\text { V Water } \\
\text { VI Water } \\
\text { vi Sedument } \\
\text { VII Water } \\
\text { vil Sediment } \\
\text { IX Water } \\
\text { IX Sediment }\end{array}$ & $\begin{array}{l}\text { no sample } \\
\text { no sample } \\
\text { no sample } \\
\text { no sample } \\
\text { no sample } \\
\text { no sample } \\
\text { no sample } \\
\text { no sample } \\
\text { no sample } \\
\text { no sample } \\
\text { no sample } \\
\text { no sample } \\
\text { no sample } \\
\text { no sample } \\
\text { no sample }\end{array}$ & \begin{tabular}{|r|}
22 \\
no sample \\
21 \\
no sample \\
22.7 \\
no sample \\
20.5 \\
22 \\
24.2 \\
20.5 \\
no sample \\
20.4 \\
no sample \\
21.4 \\
no sample
\end{tabular} & 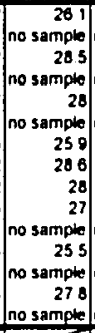 & \begin{tabular}{|r|}
27 \\
no sample \\
267 \\
no sample \\
289 \\
no sample \\
28. \\
28 \\
27.2 \\
280 \\
no sample \\
262 \\
no sample \\
26 \\
no sample \\
\end{tabular} & \begin{tabular}{|r}
25 \\
no sample \\
254 \\
no 5 ample \\
274 \\
no sample \\
206 \\
204 \\
268 \\
201 \\
no sample \\
275 \\
no sample \\
285 \\
no sample
\end{tabular} & $\begin{array}{r}216 \\
23 \\
217 \\
232 \\
216 \\
238 \\
21.7 \\
218 \\
218 \\
211 \\
232 \\
200 \\
232 \\
200 \\
238 \\
\end{array}$ & \begin{tabular}{r|}
249 \\
264 \\
247 \\
258 \\
240 \\
255 \\
247 \\
256 \\
25 \\
249 \\
262 \\
252 \\
261 \\
247 \\
26
\end{tabular} & 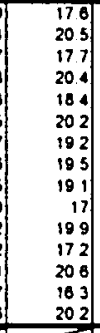 & $\begin{array}{r}13 \\
15 \\
13 \\
158 \\
12.7 \\
158 \\
126 \\
127 \\
12.5 \\
123 \\
153 \\
127 \\
15 \\
122 \\
154 \\
\end{array}$ & \begin{tabular}{r|}
185 \\
20.9 \\
18 \\
209 \\
108 \\
209 \\
18. \\
193 \\
189 \\
85 \\
208 \\
194 \\
207 \\
198 \\
206 \\
\end{tabular} & $\begin{array}{r}5.7 \\
16 \\
15.5 \\
15.5 \\
\text { nal } \\
14.5 \\
15 \\
58 \\
6 \\
5.7 \\
15 \\
58 \\
15 \\
55 \\
15 \\
\text { nn } \\
\end{array}$ & $\begin{array}{r}12 . \\
152 \\
102 \\
\text { no sample } \\
11.3 \\
15.4 \\
12 \\
124 \\
12.4 \\
12 . \\
\text { no sampie } \\
124 \\
\text { no sample } \\
137 \\
\text { no sample } \\
\end{array}$ & \begin{tabular}{|l|} 
no sample \\
no sample \\
no sample \\
no sample \\
no sample \\
no sample \\
no sample \\
no sample \\
no sample \\
no sample \\
no sample \\
no sample \\
no sample \\
no sample \\
no sample
\end{tabular} & $\mid$\begin{tabular}{r|r|}
19 & 14545 \\
19 & 57143 \\
20 & 30909 \\
20 & 23333 \\
21 & 44 \\
19 & 38571 \\
20.70909 \\
2038182 \\
2033638 \\
1057273 \\
2006607 \\
19.31818 \\
201 \\
1970909 \\
2013333
\end{tabular} & $\begin{array}{r}6.82061 \\
4354502 \\
58625 \\
4.102032 \\
6.157416 \\
4324129 \\
5930844 \\
7457329 \\
7411245 \\
7800494 \\
1390748 \\
6911413 \\
1432606 \\
7201174 \\
4368374 \\
\end{array}$ \\
\hline & & $\longrightarrow$ & $\longrightarrow$ & $\longrightarrow$ & 1 & & & & & & & 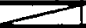 & & & \\
\hline 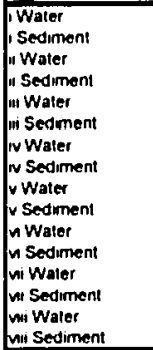 & $\begin{array}{l}\text { no sample } \\
\text { no sample } \\
\text { no sample } \\
\text { no sample } \\
\text { no sample } \\
\text { no sample } \\
\text { no sample } \\
\text { no sample } \\
\text { no sample } \\
\text { no sample } \\
\text { no sample } \\
\text { no sample } \\
\text { no sample } \\
\text { no sample } \\
\text { no sample } \\
\text { no sample }\end{array}$ & $\begin{array}{r}20 . \\
\text { no sample } \\
21.2 \\
\text { no sample } \\
22.8 \\
\text { no sample } \\
21.3 \\
\text { no sample } \\
20.0 \\
\text { no sample } \\
10.4 \\
\text { no sample } \\
20.9 \\
\text { no sample } \\
19.4 \\
\text { no sample }\end{array}$ & 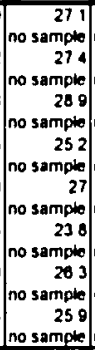 & \begin{tabular}{|r|}
22 \\
no sample \\
21 \\
no sample \\
21 \\
no sample \\
21 \\
no sample \\
21.3 \\
no samplo \\
215 \\
no sample \\
205 \\
no sample \\
213 \\
no sample
\end{tabular} & \begin{tabular}{|l|} 
no sample \\
no sample \\
no sample \\
no sample \\
no sample \\
no sample \\
no sample \\
no sample \\
no sample \\
no sample \\
no sample \\
no sample \\
no sample \\
no sample \\
no sample \\
no sampde
\end{tabular} & \begin{tabular}{|c|} 
no eval \\
230 \\
no eval \\
243 \\
no eval \\
246 \\
no eval \\
267 \\
no eval \\
253 \\
no eval \\
247 \\
no eval \\
239 \\
no eval \\
25
\end{tabular} & $\begin{array}{l}227 \\
237 \\
229 \\
23 \\
23 \\
24 \\
227 \\
24 \\
23 \\
23 \\
22 \\
24 \\
24 \\
226 \\
237 \\
226 \\
239\end{array}$ & 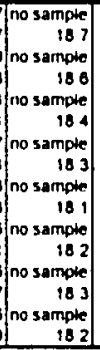 & 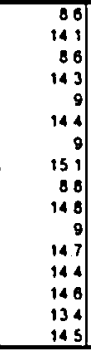 & $\begin{array}{r}197 \\
205 \\
194 \\
208 \\
187 \\
207 \\
20 \\
208 \\
198 \\
208 \\
191 \\
20.8 \\
201 \\
208 \\
202 \\
206\end{array}$ & 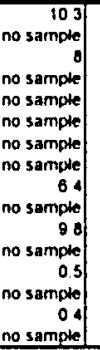 & $\begin{array}{l}139 \\
152 \\
136 \\
152 \\
133 \\
154 \\
135 \\
157 \\
135 \\
155 \\
131 \\
156 \\
1336 \\
158 \\
149\end{array}$ & $\begin{array}{l}\text { no sample } \\
\text { no sample } \\
\text { no sample } \\
\text { no sample } \\
\text { no sample } \\
\text { no sample } \\
\text { no sample } \\
\text { no sample } \\
\text { no sample } \\
\text { no sample } \\
\text { no sample } \\
\text { no sample } \\
\text { no sample }\end{array}$ & $\begin{array}{r}1815 \\
193 \\
17875 \\
1038333 \\
1962857 \\
196 \\
1901429 \\
201 \\
176125 \\
1963333 \\
171825 \\
1968333 \\
173625 \\
1948333 \\
172625 \\
1975\end{array}$ & \begin{tabular}{|c|}
6500017 \\
4086563 \\
7041501 \\
4121852 \\
6669761 \\
1303022 \\
5692518 \\
1622988 \\
7263497 \\
4235878 \\
579481 \\
4.233871 \\
7.96814 \\
393315 \\
7905141 \\
1180314
\end{tabular} \\
\hline
\end{tabular}

Table B-2 Sample Temperatures (2004)

\begin{tabular}{|c|c|c|c|c|c|c|c|c|c|c|}
\hline Dale & 25. Mayo4 & $9 \cdot$ Jun.04 & 23-Jun.04 & 6-Jul-04 & 20-Jul.04 & 4.Aug.04 & Average & Sid Der & Maximum & TMinimum \\
\hline $\begin{array}{l}\text { Lagoon } \\
\text { Exercise nunon } \\
\text { Facultative Pond } \\
\text { Cell } 1 \text { intuent } \\
\text { Coll } 2 \text { influent } \\
\text { Coll } 3 \text { mfluent } \\
\text { Cell } 3 \text { effuent } \\
\text { Finer Sting Runoff }\end{array}$ & $\begin{array}{r}142 \\
147 \\
15 \\
12.1 \\
115 \\
119 \\
12 \\
112\end{array}$ & \begin{tabular}{|r|r|}
0 eval & \\
31.6 \\
30 & 1 \\
26 & 1 \\
26 & 3 \\
27 & 7 \\
32 & 3 \\
25 & 1 \\
\end{tabular} & $\begin{array}{r}22 \\
192 \\
21 \\
18 \\
17 \\
16.1 \\
148 \\
15\end{array}$ & $\begin{array}{r}22 \\
19.4 \\
21.7 \\
183 \\
163 \\
161 \\
\text { no samplo } \\
\text { no sampie } \\
\end{array}$ & $\begin{array}{r}243 \\
228 \\
246 \\
19 \\
197 \\
199 \\
188 \\
196 \\
\end{array}$ & $\begin{array}{r}23 \\
21 \\
24 \\
17 \\
17 \\
168 \\
15\end{array}$ & $\begin{array}{r}211 \\
2145 \\
22.73333 \\
18+1667 \\
1796667 \\
1808333 \\
1854 \\
17725 \\
\end{array}$ & $\begin{array}{r}3971146 \\
5654644 \\
4964541 \\
4504849 \\
4876748 \\
5357767 \\
8065854 \\
599743 \\
\end{array}$ & $\begin{array}{ll}24 & 3 \\
31 & 6 \\
30 & 1 \\
26 & 1 \\
26 & 3 \\
27.7 \\
32.3 \\
25 & 1 \\
\end{array}$ & $\begin{array}{r}142 \\
147 \\
15 \\
12 \\
115 \\
119 \\
12 \\
112\end{array}$ \\
\hline 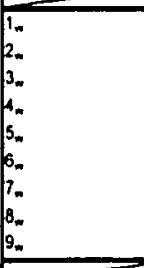 & $\begin{array}{l}\text { no sample } \\
\text { no sample } \\
\text { no sample } \\
\text { no samplo } \\
\text { no sample } \\
\text { no sample } \\
\text { no sample } \\
\text { no samplo } \\
\text { no samplo }\end{array}$ & $\begin{array}{l}195 \\
197 \\
227 \\
22.7 \\
23.9 \\
251 \\
25.7\end{array}$ & $\begin{array}{r}16 \\
18 \\
18 \\
169 \\
16.3 \\
157 \\
16 \\
18\end{array}$ & $\begin{array}{r}175 \\
17 \\
672 \\
164 \\
172\end{array}$ & $\begin{array}{l}\text { tracer } \\
\text { tracer } \\
\text { tracer } \\
\text { tracer } \\
\text { tracer } \\
\text { tracer } \\
\text { tracer } \\
\text { tracer } \\
\text { tracer }\end{array}$ & $\begin{array}{|rr|} & 184 \\
& 18 \\
& 186 \\
\text { tracer } & \\
\text { tracer } & \\
\text { tracer } & \\
\text { tracer } & \\
\text { tracer } & \\
\text { tracer } & \\
\end{array}$ & $\begin{array}{r}17.96667 \\
17.9 \\
186 \\
18 \\
19.03333 \\
1866667 \\
1893333 \\
1916667 \\
1963333 \\
\end{array}$ & $\begin{array}{l}1.789786 \\
1852026 \\
\text { WOIVIO! } \\
\text { WDNO! } \\
3189566 \\
351046 ! \\
4366158 \\
5.142308 \\
5286037\end{array}$ & $\begin{array}{r}195 \\
197 \\
186 \\
18 \\
22.7 \\
22.7 \\
23.9 \\
25.1 \\
257\end{array}$ & $\begin{array}{r}16 \\
16 \\
18 . \\
18 \\
16.9 \\
16.3 \\
15.7 \\
16 \\
16\end{array}$ \\
\hline 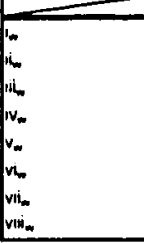 & $\begin{array}{l}\text { no sampla } \\
\text { no samplo } \\
\text { no samplo } \\
\text { no samplo } \\
\text { no samplo } \\
\text { no samplo } \\
\text { no samplo } \\
\text { no samplo }\end{array}$ & 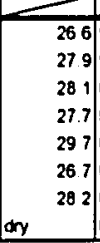 & \begin{tabular}{|l} 
tracer \\
tracer \\
tracer \\
tracer \\
tracer \\
tracer \\
tracer \\
tracer
\end{tabular} & $\begin{array}{l}165 \\
163 \\
163 \\
159 \\
162 \\
159 \\
163 \\
162\end{array}$ & $\begin{array}{l}187 \\
18.8 \\
19.1 \\
187\end{array}$ & $\begin{array}{r}17.2 \\
17.1 \\
17 \\
17.3 \\
17.3 \\
17.6 \\
18 \\
17.6\end{array}$ & $\begin{array}{r}1975 \\
20.025 \\
20.125 \\
19.9 \\
21.06667 \\
19.8 \\
20.4 \\
17.83333\end{array}$ & \begin{tabular}{|l|}
4.657068 \\
5.352492 \\
5448165 \\
5324159 \\
7.496888 \\
1771443 \\
5326037 \\
1.761628
\end{tabular} & $\begin{array}{l}26.6 \\
27.9 \\
28.1 \\
27.7 \\
29.7 \\
26.7 \\
28.2 \\
19.7\end{array}$ & $\begin{array}{l}165 \\
163 \\
16.3 \\
15.9 \\
16.2 \\
159 \\
163 \\
162\end{array}$ \\
\hline
\end{tabular}


Table B-3 Sample pH (2003)

\begin{tabular}{|c|c|c|c|c|c|c|c|c|c|c|c|c|c|c|c|}
\hline ate & -May-03 & 4.Jun-03 & 17.-vun.03 & 2.Jut03 & 15-Jut-03 & 29.5ul-03 & 11.Aun:03 & 26.Aug.03 & Q.Sep.03 & 23-Sep-03 & $7.0 \mathrm{cct} .03$ & $21.0 \mathrm{cl} \cdot 03$ & 4-Nov-03 & Average & sta Dev. \\
\hline $\begin{array}{l}\text { Exercise runooft } \\
\text { Facurative Pond } \\
\text { Cell } 1 \text { Influent } \\
\text { Cell } 2 \text { influent } \\
\text { Cell } 3 \text { mftuent } \\
\text { Cell } 3 \text { efnuent } \\
\text { Eitter Strip Runotf }\end{array}$ & $\begin{array}{r}7.36 \\
7.37 \\
7.79 \\
7.42 \\
7.4 \\
77 \\
7.2 \\
6.98 \\
\end{array}$ & $\mid \begin{array}{r}\text { no sample } \\
7.96 \\
8.2 \\
7.51 \\
7.26 \\
8.58 \\
7.85 \\
\text { no sample } \\
\end{array}$ & $\begin{array}{l}8.16 \\
.31 \\
8.39 \\
7.88 \\
7.51 \\
8.39 \\
7.1 \\
7.3 \\
\end{array}$ & $\begin{array}{r}7.74 \\
8.35 \\
9.00 \\
7.47 \\
7.9 \\
863 \\
7.23 \\
\text { sample } \\
\end{array}$ & $\begin{array}{r}8.7 \\
8.56 \\
7.93 \\
7.48 \\
7.39 \\
8.72 \\
\text { no sampie } \\
\text { no sampie } \\
\end{array}$ & \begin{tabular}{r|}
7.95 \\
9.06 \\
8.64 \\
7.61 \\
7.95 \\
8.43 \\
7.50 \\
7.6 \\
\end{tabular} & $\begin{array}{c}\text { 8.t8 } \\
\text { sample } \\
9.09 \\
7.4 \\
7.52 \\
7.79 \\
7.46 \\
759 \\
\end{array}$ & \begin{tabular}{|c|}
8.02 \\
no sample \\
8.32 \\
no sample \\
no sample \\
0.09 \\
no sample \\
no sample
\end{tabular} & $\begin{array}{r}8.11 \\
\text { no somple } \\
7.89 \\
7.64 \\
7.81 \\
0.01 \\
7.68 \\
754 \\
\end{array}$ & \begin{tabular}{|r|}
7.94 \\
no sample \\
8.17 \\
7.91 \\
8.01 \\
8.01 \\
7.82 \\
782 \\
\end{tabular} & $\mid \begin{array}{r}7.8 \\
\text { no sample } \\
83 \\
7 . \\
7.7 \\
8 \\
7.5 \\
73\end{array}$ & \begin{tabular}{|r|}
6.19 \\
no sample \\
8.52 \\
7.27 \\
7.42 \\
7.95 \\
766 \\
7.58 \\
\end{tabular} & $\begin{array}{r}73 \\
\text { no simple } \\
79 \\
7 \\
7 \\
77 \\
7 \\
71 \\
\end{array}$ & \begin{tabular}{|r|}
7.804187 \\
8.260333 \\
8.324615 \\
7.5325 \\
7.5725 \\
6.153246 \\
7.460909 \\
7.423333 \\
\end{tabular} & \begin{tabular}{|r|}
0.62302 \\
0.569611 \\
0.423195 \\
0.25976 \\
0306331 \\
0.355423 \\
0.290154 \\
0.270647 \\
\end{tabular} \\
\hline $\begin{array}{l}1 \text { Water } \\
\text { 1 Sediment } \\
2 \text { Waler } \\
2 \text { Sediment } \\
3 \text { Water } \\
3 \text { Sediment } \\
\text { 1 Waler } \\
4 \text { Sediment } \\
5 \text { Water } \\
5 \text { Sedurnent } \\
6 \text { Water } \\
6 \text { Sediment } \\
7 \text { Waler } \\
7 \text { Sediment } \\
8 \text { Waler } \\
8 \text { Sediment } \\
9 \text { Water } \\
9 \text { Sediment }\end{array}$ & \begin{tabular}{|c|} 
no sample \\
no sample \\
no sample \\
no sample \\
no sample \\
no sample \\
no sample \\
no sample \\
no sample \\
no sample \\
no sample \\
no sample \\
no sample \\
no sample \\
no sample \\
no sample \\
no sample \\
no sample
\end{tabular} & \begin{tabular}{|r|}
7.18 \\
no sample \\
7.15 \\
no sample \\
no sample \\
no sample \\
7.04 \\
no sample \\
6.82 \\
no sample \\
7.39 \\
no sample \\
6.75 \\
no sample \\
728 \\
no sample \\
7.23 \\
no sample
\end{tabular} & \begin{tabular}{|r|}
77.66 \\
no sample \\
7.28 \\
no sample \\
7.22 \\
no sample \\
7.99 \\
no sample \\
7.91 \\
no sample \\
7.35 \\
no sample \\
6.99 \\
no sample \\
7.41 \\
no sample \\
6.63 \\
no sample
\end{tabular} & $\begin{array}{r}7.19 \\
\text { no sample } \\
7.1 \\
\text { no sample } \\
7.09 \\
\text { no sample } \\
7.12 \\
\text { no sample } \\
72 \\
72 \\
\text { no sample } \\
725 \\
\text { no sample } \\
669 \\
\text { no sample } \\
709 \\
\text { no sample } \\
684 \\
\text { no sample }\end{array}$ & \begin{tabular}{|r|}
7.23 \\
no sample \\
7.26 \\
no sample \\
726 \\
no sample \\
6.9 \\
no sample \\
7.15 \\
no sample \\
7.4 \\
no sample \\
6.96 \\
no sample \\
733 \\
no sample \\
no sample \\
no sample
\end{tabular} & \begin{tabular}{l|}
7.24 \\
8.12 \\
708 \\
803 \\
7.08 \\
804 \\
7.19 \\
79 \\
727 \\
7.93 \\
7.36 \\
786 \\
702 \\
7.97 \\
7.71 \\
6.19 \\
7.6 \\
793
\end{tabular} & $\begin{array}{r}7.22 \\
7.32 \\
7.19 \\
\text { ro sample } \\
7.28 \\
756 \\
7.21 \\
7.59 \\
7.27 \\
\text { no sample } \\
7.39 \\
7.97 \\
7.33 \\
743 \\
744 \\
734 \\
7.81 \\
7.72 \\
\end{array}$ & 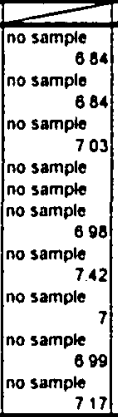 & $\begin{array}{r}765 \\
78 \\
7.9 \\
7.97 \\
752 \\
6.13 \\
771 \\
787 \\
604 \\
7.75 \\
787 \\
7.79 \\
802 \\
0.06 \\
795 \\
790 \\
805 \\
764\end{array}$ & $\begin{array}{r}74 \\
697 \\
7.2 \\
695 \\
724 \\
734 \\
756 \\
722 \\
747 \\
732 \\
741 \\
737 \\
728 \\
704 \\
772 \\
727 \\
79 \\
704\end{array}$ & $\begin{array}{rl}7.2 & n \\
692 & n \\
7.3 & n \\
693 & n \\
73 & n \\
7.15 & n \\
72 & n \\
708 & n \\
72 & n \\
702 & n \\
7.3 & n \\
738 & n \\
75 & n \\
697 & n \\
73 & n \\
709 & n \\
74 & n \\
704 & n\end{array}$ & $\begin{array}{l}\text { no sample } \\
\text { no sample } \\
\text { no sample } \\
\text { no sample } \\
\text { no sample } \\
\text { no sample } \\
\text { no sample } \\
\text { no sample } \\
\text { no sample } \\
\text { no sample } \\
\text { no sample } \\
\text { no sample } \\
\text { no sample } \\
\text { no sample } \\
\text { no sample } \\
\text { no sample } \\
\text { no sample } \\
\text { no sample }\end{array}$ & $\begin{array}{l}\text { no sample } \\
\text { no sample } \\
\text { no sample } \\
\text { no sample } \\
\text { no sample } \\
\text { no sample } \\
\text { no sample } \\
\text { no sample } \\
\text { no sample } \\
\text { no sample } \\
\text { no sample } \\
\text { no sample } \\
\text { no sample } \\
\text { no sample } \\
\text { no sample } \\
\text { no sample } \\
\text { no sample } \\
\text { no sample }\end{array}$ & $\begin{array}{r}7.307778 \\
7.326333 \\
7.271111 \\
7.344 \\
7.27125 \\
7.541667 \\
7.324444 \\
7.532 \\
737 \\
74 \\
7.413333 \\
7.631687 \\
7.171411 \\
7415 \\
7462222 \\
7473333 \\
74075 \\
7423333\end{array}$ & \begin{tabular}{|c|c|}
0161815 \\
0.525906 \\
0.247156 \\
0.60085 \\
0.163658 \\
0.458407 \\
0.352856 \\
0372384 \\
0.383927 \\
0427376 \\
0178955 \\
0.271398 \\
0.414561 \\
0502285 \\
0.284376 \\
048786 \\
0491579 \\
0387229 \\
\end{tabular} \\
\hline 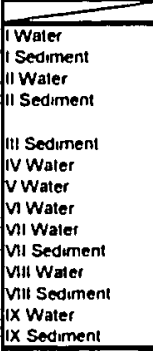 & $\begin{array}{l}\text { no sample } \\
\text { no sample } \\
\text { no sample } \\
\text { no sample } \\
\text { no sample } \\
\text { no sample } \\
\text { no sample } \\
\text { no sample } \\
\text { no sainple } \\
\text { no sample } \\
\text { no sample } \\
\text { no sample } \\
\text { no sample } \\
\text { no sample } \\
\text { no sample }\end{array}$ & 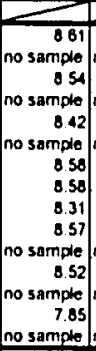 & \begin{tabular}{|c|}
763 \\
no sample \\
724 \\
no sample \\
6.97 \\
no sample \\
8.14 \\
717 \\
7.04 \\
747 \\
no sample \\
7.34 \\
no sample \\
674 \\
no sample
\end{tabular} & 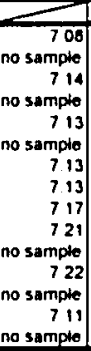 & $\begin{array}{r}8.63 \\
\text { no sample } \\
7.26 \\
\text { no sample } \\
7.33 \\
\text { no samplo } \\
764 \\
727 \\
729 \\
742 \\
7.42 \\
\text { no sample } \\
73 \\
\text { no sample } \\
7.12 \\
\text { no sampte }\end{array}$ & 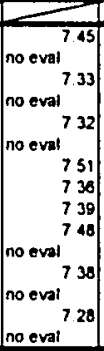 & $\begin{array}{r}r \\
6.42 \\
762 \\
766 \\
768 \\
7.7 \\
7.80 \\
779 \\
7.73 \\
7.82 \\
649 \\
785 \\
763 \\
784 \\
749 \\
\end{array}$ & $\begin{array}{l}730 \\
843 \\
769 \\
614 \\
761 \\
767 \\
802 \\
756 \\
748 \\
7.99 \\
644 \\
754 \\
725 \\
756 \\
771\end{array}$ & $\begin{array}{ll}7 & 54 \\
8 & 12 \\
7 & 54 \\
7 & 98 \\
7 & 67 \\
7 & 46 \\
7 & 54 \\
7 & 42 \\
7 & 5 \\
7 & 62 \\
6 & 12 \\
7 & 58 \\
7 & 21 \\
7 & 4 \\
7 & 20 \\
\end{array}$ & \begin{tabular}{r|r|}
788 \\
8 & 04 \\
782 \\
776 \\
783 \\
758 \\
805 \\
75 \\
778 \\
8 \\
77 \\
783 \\
73 \\
781 \\
738 \\
\end{tabular} & $\begin{array}{r}79 \\
781 \\
802 \\
767 \\
800 \\
702 \\
808 \\
78 \\
77 \\
79 \\
756 \\
79 \\
715 \\
78 \\
728 \\
720\end{array}$ & \begin{tabular}{|r|}
81 \\
75 \\
799 \\
no sample \\
707 \\
7.39 \\
012 \\
005 \\
794 \\
804 \\
no sample \\
807 \\
no sample \\
700 \\
no sample \\
\end{tabular} & \begin{tabular}{|l} 
no sample \\
no sample \\
no sample \\
no sample \\
no sample \\
no sample \\
no sample \\
no sample \\
no sample \\
no sample \\
no sample \\
no sample \\
no sample \\
no sample \\
no sample
\end{tabular} & $\begin{array}{r}7834545 \\
8053333 \\
7653638 \\
7842 \\
7635455 \\
757 \\
7879091 \\
7602727 \\
7575455 \\
7774545 \\
8062 \\
7834545 \\
7308 \\
7490909 \\
7424 \\
\end{array}$ & \begin{tabular}{|l|l|}
0 & 488802 \\
0 & 359537 \\
0 & 420791 \\
0 & 210523 \\
0 & 429007 \\
0 & 121855 \\
0 & 397076 \\
0 & 430722 \\
0 & 385441 \\
0 & 382803 \\
0 & 422043 \\
0 & 393506 \\
0 & 188202 \\
0 & 387542 \\
0 & 184201 \\
\end{tabular} \\
\hline 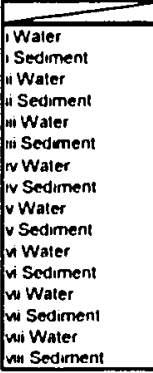 & $\begin{array}{c}\text { no sample } \\
\text { no sample } \\
\text { no sample } \\
\text { no sample } \\
\text { no sample } \\
\text { no sample } \\
\text { no sample } \\
\text { no sample } \\
\text { no sample } \\
\text { no sample } \\
\text { no sample } \\
\text { no sample } \\
\text { no sample } \\
\text { no sample } \\
\text { no sample } \\
\text { no sample }\end{array}$ & $\mid$\begin{tabular}{rr|}
704 \\
no sample \\
69 \\
no sample \\
7.63 \\
no sample \\
704 \\
no sample \\
7.38 \\
no sample \\
719 \\
no sample \\
7.27 \\
no sample \\
19.4 \\
no sample
\end{tabular} & $\begin{array}{r}7.01 \\
\text { no sample } \\
7.01 \\
\text { no sarnple } \\
6.93 \\
\text { no sample } \\
69 \\
\text { no sample } \\
7.08 \\
\text { no sample } \\
725 \\
\text { no sample } \\
71 \\
\text { no sample } \\
746 \\
\text { no sample }\end{array}$ & $\begin{array}{rr}7.21 \\
\text { no sample } \\
709 \\
\text { no sample } \\
7.12 \\
\text { no sample } \\
693 \\
\text { no sample } \\
707 \\
\text { no sample } \\
751 \\
\text { no sample } \\
712 \\
\text { no sample } \\
7.12 \\
\text { no sample }\end{array}$ & $\begin{array}{l}\text { no sample } \\
\text { no sample } \\
\text { no sample } \\
\text { no sample } \\
\text { no sainple } \\
\text { no sampte } \\
\text { no sample } \\
\text { no sample } \\
\text { no sainple } \\
\text { no sample } \\
\text { no saimple } \\
\text { no sample } \\
\text { no sample } \\
\text { no sample } \\
\text { no sample } \\
\text { no sample }\end{array}$ & $\begin{array}{ll}7 & 6 \\
7 & 84 \\
7 & 52 \\
8 & 28 \\
7 & 41 \\
8 & 41 \\
7 & 13 \\
8 & 16 \\
7 & 39 \\
678 \\
773 \\
7 & 86 \\
7.55 \\
0 & 07 \\
7.46 \\
7 & 93\end{array}$ & $\begin{array}{ll}7.29 \\
7.51 \\
765 \\
7 & 42 \\
7 & 63 \\
7 & 55 \\
7 & 16 \\
7 & 5 \\
7 & 72 \\
7 & 56 \\
7 & 33 \\
7 & 48 \\
7 & 65 \\
77 & 75 \\
7 & 4 \\
7 & 25\end{array}$ & 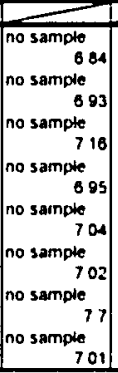 & 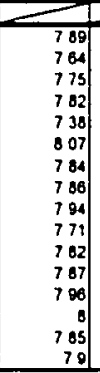 & 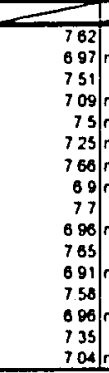 & $\begin{array}{r}798 \\
\text { no sample } \\
800 \\
80 \\
\text { no sample } \\
\text { no sample } \\
\text { no sample } \\
\text { no sampte } \\
\text { no sampte } \\
7.94 \\
\text { no sample } \\
81 \\
\text { no sample } \\
78 \\
\text { no sampte } \\
78 \\
\text { no sample }\end{array}$ & $\begin{array}{ll}7 & 7 \\
6 & 55 \\
7 & 36 \\
6 & 88 \\
7 & 49 \\
7 & 12 \\
7 & 84 \\
6 & 89 \\
7 & 68 \\
6 & 96 \\
7 & 59 \\
6 & 98 \\
7 & 82 \\
6 & 93 \\
7 & 77 \\
8 & 91\end{array}$ & $\begin{array}{l}\text { no sample } \\
\text { no sample } \\
\text { no sample } \\
\text { no sample } \\
\text { no sample } \\
\text { no sample } \\
\text { no sample } \\
\text { no sample } \\
\text { no sample } \\
\text { no sample } \\
\text { no sample } \\
\text { no sample } \\
\text { no sample } \\
\text { no sample } \\
\text { no sample } \\
\text { no sample }\end{array}$ & $\begin{array}{r}7.482222 \\
7275 \\
743 \\
7403333 \\
733825 \\
7593333 \\
73125 \\
7.378333 \\
7542222 \\
7501667 \\
7574444 \\
7353333 \\
7535889 \\
7568333 \\
8845556 \\
734 \\
7\end{array}$ & $\begin{array}{ll}0 & 357783 \\
0 & 440579 \\
0 & 381707 \\
0 & 554713 \\
0 & 245586 \\
0 & 533891 \\
0 & 400812 \\
0 & 549742 \\
0 & 330332 \\
0 & 704398 \\
0 & 292323 \\
0 & 444237 \\
0 & 312087 \\
0 & 503167 \\
3 & 605174 \\
0 & 459042\end{array}$ \\
\hline
\end{tabular}

Table B-t Sample pH (200+t)

\begin{tabular}{|c|c|c|c|c|c|c|c|c|}
\hline Date & 25-May-04 & 9.Jun-04 & 23.Jun.04 & 6.Jul.04 & $20-\mathrm{J} \backslash u \mid-04$ & 4.Aug-04) & Average & Std Dev \\
\hline $\begin{array}{l}\text { Lagoon } \\
\text { Exercise runoff } \\
\text { Facultalive Pond } \\
\text { Cell } 1 \text { Influent } \\
\text { Cell } 2 \text { influent } \\
\text { Cell } 3 \text { influent } \\
\text { Cell } 3 \text { eflluent } \\
\text { Filler Strip Runotf }\end{array}$ & $\begin{array}{r}7.36 \\
7.85 \\
808 \\
7.5 \\
7.34 \\
7.31 \\
7.03 \\
723 \\
\end{array}$ & $\begin{array}{r}7 \\
794 \\
8.01 \\
766 \\
741 \\
7.62 \\
7.36 \\
725 \\
\end{array}$ & $\begin{array}{r}772 \\
7.9 \\
795 \\
7.58 \\
7.44 \\
771 \\
7.33 \\
7.48\end{array}$ & \begin{tabular}{|r|}
768 \\
8.1 \\
817 \\
699 \\
73 \\
729 \\
no sample \\
no sample
\end{tabular} & $\begin{array}{r}77 \\
756 \\
855 \\
735 \\
7.38 \\
727 \\
725 \\
729\end{array}$ & 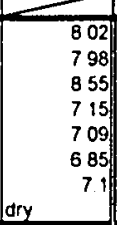 & \begin{tabular}{|r|}
7.58 \\
78883333 \\
82183333 \\
73716667 \\
7.3266667 \\
7.3416667 \\
7214 \\
73125 \\
\end{tabular} & $\begin{array}{ll}0 & 352817 \\
0 & 181815 \\
0 & 267164 \\
0 & 260109 \\
0 & 126122 \\
0 & 304527 \\
0 & 143979 \\
0 & 114419\end{array}$ \\
\hline $\begin{array}{l}1 w \\
2 w \\
3 w \\
4 w \\
5 w \\
6 w \\
7 w \\
8 w \\
9 w\end{array}$ & $\begin{array}{l}\text { no sample } \\
\text { no sample } \\
\text { no sample } \\
\text { no sample } \\
\text { no sample } \\
\text { no sample } \\
\text { no sample } \\
\text { no sample } \\
\text { no sample }\end{array}$ & 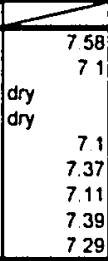 & \begin{tabular}{ll|}
7 & 13 \\
7.17 \\
7 & 46 \\
7.06 \\
7 & 21 \\
7.19 \\
7 & 22 \\
7.34
\end{tabular} & \begin{tabular}{r|} 
\\
\\
6.96 \\
7.24 \\
7.06 \\
7.48 \\
71
\end{tabular} & $\begin{array}{l}\text { tracer } \\
\text { tracer } \\
\text { tracer } \\
\text { tracer } \\
\text { tracer } \\
\text { tracer } \\
\text { tracer } \\
\text { tracer } \\
\text { tracer }\end{array}$ & 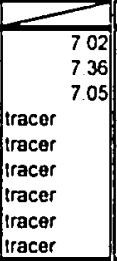 & $\begin{array}{r}72433333 \\
7.21 \\
7.05 \\
746 \\
7.04 \\
72733333 \\
7.12 \\
73633333 \\
72433333 \\
\end{array}$ & $\begin{array}{l}\text { O296704 } \\
0.134536 \\
\text { \#DIVN! } \\
\text { \#D:VNo' } \\
0072111 \\
0085049 \\
0065574 \\
0 \quad 132035 \\
0126623\end{array}$ \\
\hline 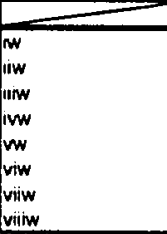 & $\begin{array}{l}\text { no sample } \\
\text { no sample } \\
\text { no sample } \\
\text { no sample } \\
\text { no sample } \\
\text { no sample } \\
\text { no sample } \\
\text { no sample }\end{array}$ & $\begin{array}{l}7.12 \\
6.94 \\
7.35 \\
7.06 \\
7.44 \\
7.17 \\
7.11\end{array}$ & $\begin{array}{l}\text { tracer } \\
\text { tracer } \\
\text { tracer } \\
\text { tracer } \\
\text { tracer } \\
\text { tracer } \\
\text { tracer } \\
\text { tracer }\end{array}$ & $\begin{array}{l}7.19 \\
7.11 \\
7.16 \\
7.05 \\
7.08 \\
742 \\
719 \\
731\end{array}$ & \begin{tabular}{ll|}
7 & 16 \\
6 & 93 \\
7 & 22 \\
7 & 26
\end{tabular} & \begin{tabular}{rr|}
709 \\
7 & 1 \\
7.11 \\
707 \\
7.32 \\
708 \\
7.17 \\
722
\end{tabular} & \begin{tabular}{|r|}
714 \\
7.02 \\
7.21 \\
7.11 \\
728 \\
7.2125 \\
7.2125 \\
7.3233333 \\
\end{tabular} & $\begin{array}{r} \\
0.04397 \\
0.098319 \\
0.103602 \\
0.100333 \\
0.183303 \\
0.145459 \\
01116726 \\
0.110604\end{array}$ \\
\hline
\end{tabular}


Table B-5 Sample Dissolved Oxygen Concentrations (2003)

\begin{tabular}{|c|c|c|c|c|c|c|c|c|c|c|c|c|c|c|c|}
\hline ste & 21-May.03 & 4.Jun.03] & $17 . \operatorname{Jun} .03$ & 2-Jul.03 & 15-Ju1-.03 & 29.Jul.03 & 1.Aug.03 & $26 . A 49.03$ & 9.5ep.03 & 23-Sep-03 & 7.0 ct. 03 & $21.0 \mathrm{ct} \cdot 03$ & 4.Nov.03 & Average & Sld Dev. \\
\hline 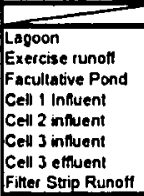 & $\begin{array}{r}1.46 \\
1.34 \\
1.5 \\
1.86 \\
7 \\
3.87 \\
2.5\end{array}$ & \begin{tabular}{|r|} 
no sample \\
0 \\
5.5 \\
1.89 \\
0 \\
11.17 \\
5 \\
no sample
\end{tabular} & 0 & $\begin{array}{r}0.09 \\
7.06 \\
\text { no value } \\
3.62 \\
\text { outrier } \\
11.8 \\
1.39 \\
\text { no sample } \\
\end{array}$ & $\mid \begin{array}{r}\text { outrer } \\
3.15 \\
\text { outiter } \\
2.23 \\
22 \\
3.72 \\
\text { no zample } \\
\text { no sample }\end{array}$ & $\begin{array}{r}0.09 \\
12.47 \\
3.5 \\
1.6 \\
07 \\
33 \\
2.33 \\
1.9 \\
\end{array}$ & \begin{tabular}{r|}
0.02 \\
0.1 \\
0 \\
0.15 \\
0 \\
0 \\
0 \\
\end{tabular} & $\begin{array}{l}\text { no plobe } \\
\text { no plobe } \\
\text { no plobe } \\
\text { no probe } \\
\text { no probe } \\
\text { no probe } \\
\text { no probe } \\
\text { no probe }\end{array}$ & $\begin{array}{r}\text { no sample } \\
0 \\
0.5 \\
0.08 \\
0.07 \\
165 \\
0.01\end{array}$ & $\begin{array}{l}0 \\
0 \\
0 \\
0 \\
0 \\
0 \\
0\end{array}$ & $\begin{array}{c}0.15 \\
3.34 \\
2.56 \\
3.57 \\
2.9 \\
4.37\end{array}$ & $\begin{array}{r}\text { cample } \\
0 \\
0.44 \\
027 \\
1.05 \\
1.15 \\
1.27\end{array}$ & \begin{tabular}{|r|} 
no sarnple \\
0.4 \\
2.02 \\
2.74 \\
429 \\
397 \\
483
\end{tabular} & $\begin{array}{r}0022222 \\
1023333 \\
1699 \\
1.428333 \\
0.96 \\
3889167 \\
2.041810 \\
1742222 \\
\end{array}$ & \begin{tabular}{|r|}
003898 \\
4.904596 \\
2.422627 \\
1.266971 \\
1.132034 \\
4.140578 \\
1.740418 \\
1845154 \\
\end{tabular} \\
\hline 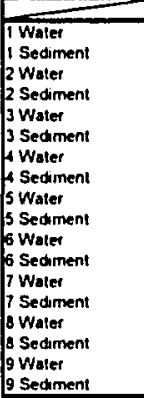 & $\begin{array}{l}\text { no sample } \\
\text { no sample } \\
\text { no sample } \\
\text { no sample } \\
\text { no sample } \\
\text { no sample } \\
\text { no sample } \\
\text { no sample } \\
\text { no sample } \\
\text { no sample } \\
\text { no sample } \\
\text { no sample } \\
\text { no sample } \\
\text { no sample } \\
\text { no sample } \\
\text { no sample } \\
\text { no sample } \\
\text { no sample }\end{array}$ & 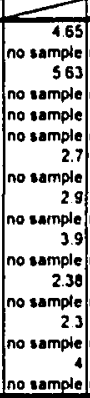 & 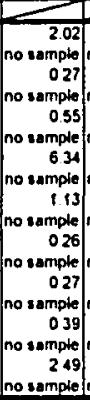 & \begin{tabular}{|r|}
1.35 \\
no sample \\
1.25 \\
no eample \\
1.7 \\
no sample \\
068 \\
no sample \\
072 \\
no sample \\
0.45 \\
no sample \\
0.79 \\
no sample \\
051 \\
no sample \\
0.75 \\
no sample
\end{tabular} & 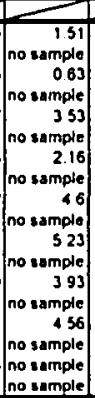 & \begin{tabular}{r|r|}
5.95 \\
53 \\
593 \\
46 \\
75 \\
39 \\
3.78 \\
454 \\
74 \\
46 \\
636 \\
476 \\
639 \\
340 \\
85 \\
436 \\
858 \\
399 \\
3
\end{tabular} & \begin{tabular}{|r|}
2.6 \\
5.01 \\
166 \\
no sample \\
456 \\
499 \\
307 \\
485 \\
229 \\
229 \\
no esmple \\
254 \\
3357 \\
244 \\
361 \\
199 \\
3 \\
282 \\
362 \\
\end{tabular} & $\begin{array}{l}\text { no probe } \\
\text { no probe } \\
\text { no probe } \\
\text { no probe } \\
\text { no probe } \\
\text { no probe } \\
\text { no probe } \\
\text { no probe } \\
\text { no probe } \\
\text { no probe } \\
\text { no probe } \\
\text { no porobe } \\
\text { no probe } \\
\text { no pobe } \\
\text { no pobe } \\
\text { no probe } \\
\text { no probe } \\
\text { no probe }\end{array}$ & $\begin{array}{l}5.2 \\
5.45 \\
653 \\
4.51 \\
693 \\
572 \\
6.98 \\
605 \\
743 \\
499 \\
683 \\
953 \\
585 \\
568 \\
654 \\
006 \\
744 \\
661\end{array}$ & 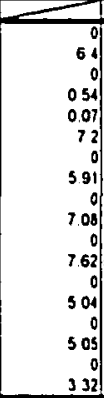 & \begin{tabular}{|r|}
0.72 \\
1.49 \\
0.78 \\
3.95 \\
0.99 \\
399 \\
1.38 \\
0.42 \\
0.37 \\
2.39 \\
1.47 \\
no eval \\
213 \\
1.7 \\
0.2 \\
2.48 \\
180 \\
no eval
\end{tabular} & \begin{tabular}{|l|} 
no sample \\
no sample \\
no semple \\
no sample \\
no sample \\
no sample \\
no sample \\
no sample \\
no sample \\
no sample \\
no sample \\
no sample \\
no ssmple \\
no sample \\
no sample \\
no semple \\
no sample \\
no sample
\end{tabular} & \begin{tabular}{|l|} 
no sample \\
no sample \\
no sample \\
no sample \\
no sample \\
no sample \\
no sample \\
no sample \\
no sample \\
no sample \\
no sample \\
no sample \\
no sample \\
no sample \\
no sample \\
no sample \\
no sample \\
no sample
\end{tabular} & \begin{tabular}{|r|}
2.777778 \\
4.73 \\
252 \\
34 \\
3.2225 \\
3532 \\
301 \\
4354 \\
2962222 \\
4765 \\
3006667 \\
6.37 \\
2908389 \\
3902 \\
2776667 \\
2.99 \\
3495 \\
4385
\end{tabular} & \begin{tabular}{|c|}
2.317918 \\
1.884688 \\
2686666 \\
1.928229 \\
2891721 \\
1540412 \\
2.382509 \\
2.29426 \\
2886788 \\
1921605 \\
2679953 \\
2706794 \\
2.755828 \\
1346648 \\
3084814 \\
193427 \\
3050926 \\
1500432 \\
\end{tabular} \\
\hline 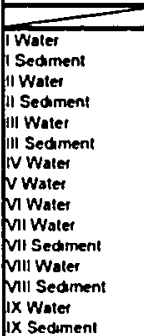 & $\begin{array}{l}\text { ho sample } \\
\text { no sample } \\
\text { no sample } \\
\text { no sample } \\
\text { no sample } \\
\text { no simple } \\
\text { no sumple } \\
\text { no sample } \\
\text { no sample } \\
\text { no sample } \\
\text { no sample } \\
\text { no sample } \\
\text { no sample } \\
\text { no sample } \\
\text { no sample }\end{array}$ & 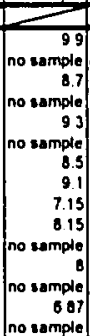 & 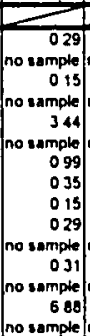 & 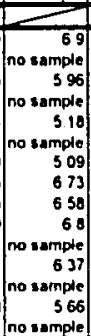 & $\mid \begin{array}{r}299 \\
\text { no somple } \\
5 \\
\text { no sample } \\
626 \\
\text { no sample } \\
49 \\
501 \\
535 \\
51 \\
\text { no } 30 \text { mple } \\
305 \\
\text { no sample } \\
24 \\
\text { no sumple }\end{array}$ & $\begin{array}{ll}5 & 22 \\
4 & 59 \\
4 & 92 \\
3 & 72 \\
4 & 1 \\
4 & 26 \\
3 & 11 \\
4 & 06 \\
6 & 01 \\
5 & 6 \\
2 & 45 \\
5 & 5 \\
3 & 68 \\
4 & 42 \\
3 & 04\end{array}$ & 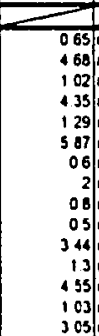 & $\begin{array}{l}\text { Do probe } \\
\text { no probe } \\
\text { no probe } \\
\text { no probe } \\
\text { no probe } \\
\text { no probe } \\
\text { no probe } \\
\text { no probe } \\
\text { no probe } \\
\text { no probe } \\
\text { no probe } \\
\text { no probe } \\
\text { no probe } \\
\text { no probe } \\
\text { no probe }\end{array}$ & 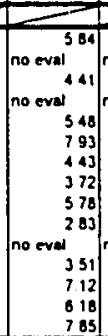 & $\begin{array}{r}367 \\
356\end{array}$ & 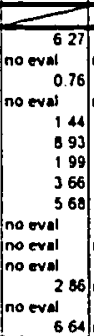 & no eveve 1.22 & $\begin{array}{l}\text { no sample } \\
\text { no sample } \\
\text { no sample } \\
\text { no cample } \\
\text { no cample } \\
\text { no sample } \\
\text { no sample } \\
\text { no sample } \\
\text { no sample } \\
\text { no semple } \\
\text { no sample } \\
\text { no somple } \\
\text { no sample } \\
\text { no sample } \\
\text { no sample }\end{array}$ & $\begin{array}{r}4228 \\
4635 \\
3259 \\
4035 \\
3833 \\
524 \\
3489 \\
3705 \\
3929 \\
3365556 \\
2945 \\
3432222 \\
4372 \\
3866667 \\
3228 \\
32\end{array}$ & \begin{tabular}{|l|}
3245201 \\
006364 \\
3057621 \\
0445477 \\
2816389 \\
2884136 \\
2629565 \\
2751471 \\
2873799 \\
3111937 \\
07000656 \\
2939764 \\
1646414 \\
2701995 \\
2151156
\end{tabular} \\
\hline & D to & 1 & $\longrightarrow$ & 1 & 1 & & & s. & & & & & & r... & . \\
\hline 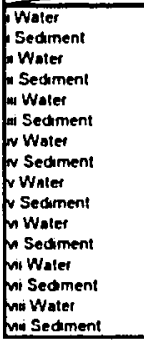 & $\begin{array}{l}\text { no somple } \\
\text { no sample } \\
\text { no sample } \\
\text { no sample } \\
\text { no ssmple } \\
\text { no sample } \\
\text { no sample } \\
\text { no sumple } \\
\text { no sample } \\
\text { no semple } \\
\text { ho semple } \\
\text { no semple } \\
\text { no sample } \\
\text { no sumple } \\
\text { no sample } \\
\text { no sample }\end{array}$ & 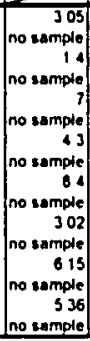 & \begin{tabular}{|r|}
217 \\
no sample \\
12 \\
no sample \\
259 \\
no sample \\
053 \\
no sample \\
263 \\
no sample \\
291 \\
no somple \\
29 \\
no sample \\
321 \\
no somple
\end{tabular} & 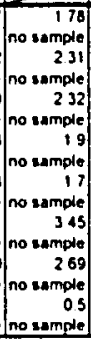 & 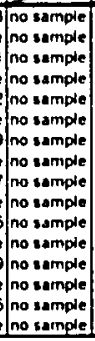 & \begin{tabular}{rr|}
6 & 42 \\
4 & 8 \\
6 & 44 \\
4 & 9 \\
6 & 45 \\
4 & 06 \\
6 & 9 \\
4 & 24 \\
6 & 75 \\
4 & 2 \\
6 & 1 \\
4 & 44 \\
6 & 6 \\
4 & 28 \\
6 & 1 \\
4 & 15
\end{tabular} & \begin{tabular}{rr|} 
& 05 \\
4 & 53 \\
2 & 49 \\
3 & 83 \\
1 & 82 \\
2 & 68 \\
2 & 2 \\
2 & 32 \\
6 \\
316 \\
1 & 45 \\
4 & 57 \\
1 & 33 \\
3 & 36 \\
1 & 36 \\
2 & 62
\end{tabular} & $\begin{array}{l}\text { no probe } \\
\text { no probe } \\
\text { no probe } \\
\text { no probe } \\
\text { no probe } \\
\text { no probe } \\
\text { no probe } \\
\text { no probe } \\
\text { no prose } \\
\text { no probe } \\
\text { no prose } \\
\text { no probe } \\
\text { no prose } \\
\text { no probe } \\
\text { no probe } \\
\text { no probe }\end{array}$ & $\begin{array}{ll}7 & 78 \\
2 & 44 \\
6 & 59 \\
6 & 6 \\
6 & 26 \\
6 & 34 \\
5 & 95 \\
6 & 94 \\
6 & 94 \\
5 & 76 \\
6 & 88 \\
6 & 52 \\
6 & 91 \\
7 & 45 \\
5 & 72 \\
4 & 83 \\
\end{array}$ & \begin{tabular}{rr|}
0 & 9 \\
0 & 96 \\
1 & 36 \\
1 & 99 \\
0 & 13 \\
5 & 99 \\
0 \\
0 \\
0 \\
0 \\
30 \\
0 \\
1 & 35 \\
0 \\
2 & 25 \\
1 & 07 \\
0 & 19
\end{tabular} & 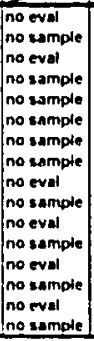 & \begin{tabular}{ll|}
2 & 06 \\
2 & 30 \\
0 & 16 \\
2 & 09 \\
0 \\
1 \\
156 \\
1 & 38 \\
3 & 22 \\
0 & 4 \\
1 & 93 \\
0 & 57 \\
1 & 75 \\
2 & 52 \\
3 & 37 \\
0 & 87 \\
4 & 07
\end{tabular} & $\begin{array}{l}\text { no sample } \\
\text { no sample } \\
\text { no sample } \\
\text { no sumple } \\
\text { no sumple } \\
\text { no semple } \\
\text { no sample } \\
\text { no sample } \\
\text { no somple } \\
\text { no sample } \\
\text { no sample } \\
\text { no somple } \\
\text { no somple } \\
\text { no somple } \\
\text { no sample } \\
\text { no sample }\end{array}$ & $\begin{array}{r}315375 \\
3022 \\
274375 \\
3852 \\
332125 \\
4096 \\
287 \\
3344 \\
38525 \\
367 \\
30475 \\
3726 \\
35625 \\
419 \\
302375 \\
3052\end{array}$ & \begin{tabular}{|l|}
2599346 \\
1615401 \\
2454506 \\
1950479 \\
2852675 \\
2026988 \\
2546779 \\
2548545 \\
2974149 \\
1420704 \\
2454209 \\
215514 \\
2501564 \\
1963403 \\
2385042 \\
1914372
\end{tabular} \\
\hline
\end{tabular}

Table B-6 Sample Dissolved Oxygen Concentrations (2004)

\begin{tabular}{|c|c|c|c|c|c|c|c|c|}
\hline Dato & 25-May-04 & 9. Jun-od & 23-Jun.04 & 6-Jut-0, & $20-\sqrt{1}+04$ & 4Awg-04 & Average & Sid Dev \\
\hline $\begin{array}{l}\text { Locon } \\
\text { Exercise runoif } \\
\text { Foculative Pond } \\
\text { Cell } 1 \text { influent } \\
\text { Cell } 2 \text { infuent } \\
\text { Cell } 3 \text { miluent } \\
\text { Cell } 3 \text { emuent } \\
\text { Finer Sinp Runolf }\end{array}$ & 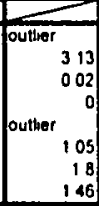 & \begin{tabular}{r|}
0 \\
4 \\
49 \\
0 \\
0 \\
0 \\
101 \\
229 \\
156 \\
\end{tabular} & $\begin{array}{r}0 \\
0 \\
0 \\
0 \\
0 \\
231 \\
028 \\
13\end{array}$ & $\begin{array}{r}0 \\
0 \\
0 \\
0 \\
0 \\
0 \\
0 \\
\text { no sample } \\
\text { no sample }\end{array}$ & \begin{tabular}{r|}
0 \\
0 \\
09 \\
187 \\
0 \\
0 \\
0 \\
0 \\
0 \\
062
\end{tabular} & $\begin{array}{r}9 \\
0 \\
0 \\
0 \\
0 \\
0 \\
0\end{array}$ & \begin{tabular}{|r|}
0 \\
137 \\
0.485 \\
0 \\
0 \\
07283333 \\
08874 \\
1235
\end{tabular} & $\begin{array}{rr}0 \\
1 \text { 838565 } \\
0.77588 \\
0 \\
0 \\
0.924758 \\
1.088935 \\
0.423753\end{array}$ \\
\hline 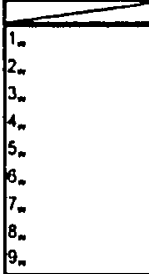 & \begin{tabular}{|l|} 
no sample \\
no sample \\
no sample \\
no sample \\
no sample \\
no sample \\
no sample \\
no sample \\
no sample
\end{tabular} & $\begin{array}{ll} & 031 \\
& 03 \\
d y & \\
d y & \\
& 051 \\
& 0.06 \\
& 04 \\
& 0 \\
& 4.92\end{array}$ & $\begin{array}{l}0 \\
0 \\
0\end{array}$ & \begin{tabular}{r|} 
\\
14 \\
136 \\
151 \\
369 \\
206
\end{tabular} & $\begin{array}{l}\text { tracer } \\
\text { iracor } \\
\text { iracer } \\
\text { tracer } \\
\text { tracer } \\
\text { iracer } \\
\text { tracer } \\
\text { iracer } \\
\text { iracer }\end{array}$ & $\begin{array}{l}\text { tracer } \\
\text { tracer } \\
\text { tracer } \\
\text { iracer } \\
\text { tracer } \\
\text { iracer }\end{array}$ & 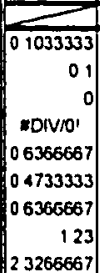 & \begin{tabular}{|r|}
0.178979 \\
0173205 \\
0 \\
0 OIVror \\
0708543 \\
0768462 \\
0782326 \\
2.130422 \\
2470816
\end{tabular} \\
\hline 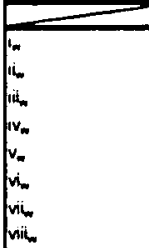 & \begin{tabular}{|l|} 
no sample \\
no sample \\
no sample \\
no sample \\
no samplo \\
no sample \\
no sample \\
no semplo
\end{tabular} & \begin{tabular}{r|}
2.72 \\
0.15 \\
226 \\
2.18 \\
2.94 \\
18 \\
1.68
\end{tabular} & \begin{tabular}{|l} 
tracer \\
tracer \\
tracer \\
tracer \\
tracer \\
tracer \\
tracer \\
tracer
\end{tabular} & \begin{tabular}{r|}
416 \\
324 \\
2.7 \\
285 \\
303 \\
2.72 \\
391 \\
4.34 \\
\end{tabular} & $\begin{array}{r}0 \\
0 \\
087 \\
2.49 \\
1.47\end{array}$ & $\begin{array}{r}1.25 \\
1.7 \\
2.11 \\
1.81 \\
3.16 \\
0 \\
2.7 \\
1.76\end{array}$ & \begin{tabular}{|r|}
20325 \\
1.49 \\
2.39 \\
20775 \\
3.0433333 \\
1.13 \\
2.3925 \\
29933333 \\
\end{tabular} & \begin{tabular}{|l|}
1802061 \\
1327479 \\
0.259108 \\
0591009 \\
0.110604 \\
1.357792 \\
1175113 \\
1293728
\end{tabular} \\
\hline
\end{tabular}


Table B-7 Sample TSS Concentrations (2003)

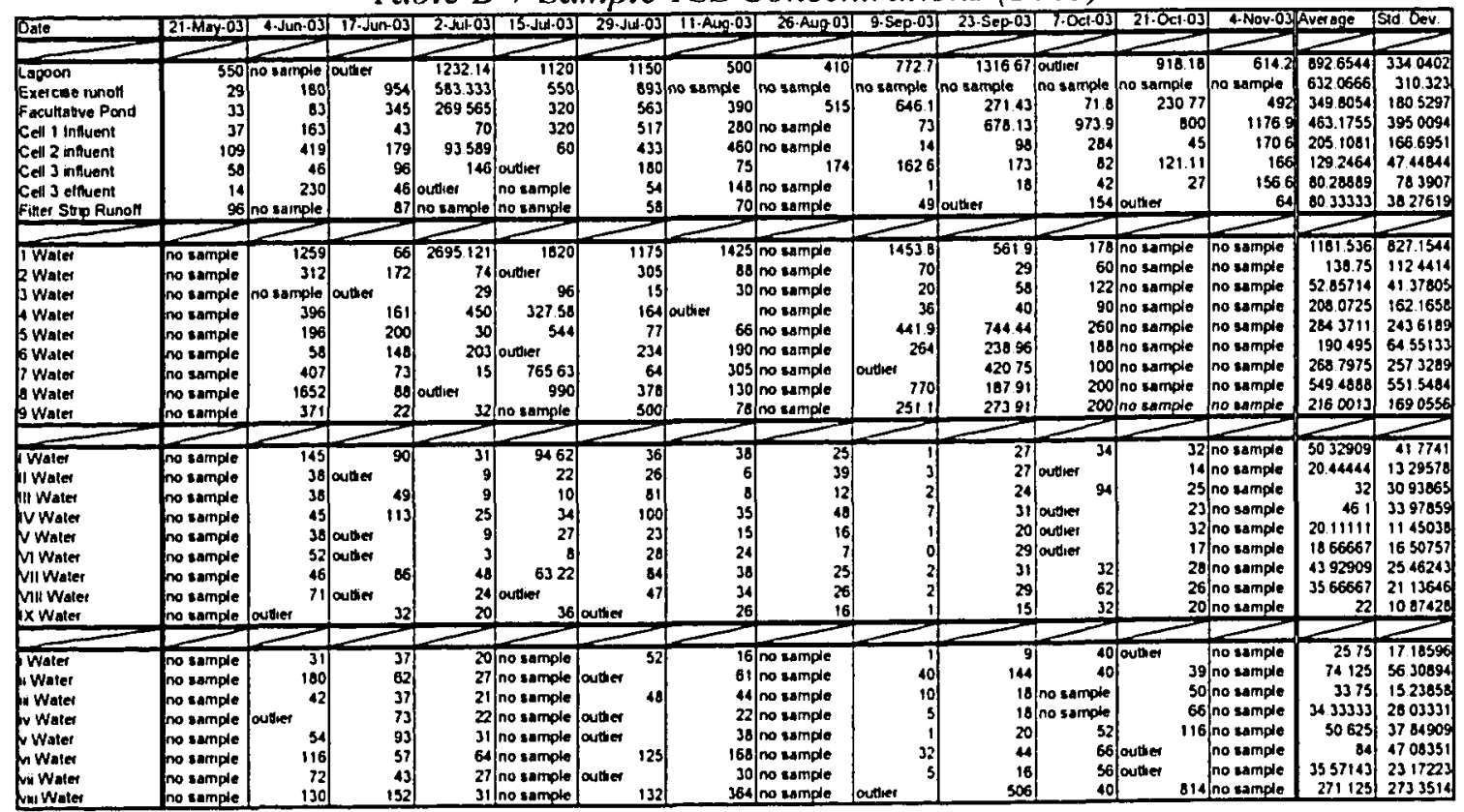

Table B-8 Sample TSS Concentrations (2004)

\begin{tabular}{|c|c|c|c|c|c|c|c|c|}
\hline bato & $25 . \mathrm{May}+\mathrm{O}$ & 8-Jun-04 & 23-Jun-04 & 6-Jul-04! & $20 . J u t-04$ & 4.Aug-04 & Average & Std Dev \\
\hline 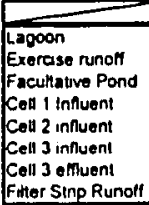 & \begin{tabular}{|r|r|} 
& 5 \\
& 5333 \\
Outtier & \\
Outlier & \\
535 \\
139 \\
1380 \\
\end{tabular} & $\begin{array}{r}490 \\
3 \\
16 \\
13 \\
20 \\
0 \\
2 \\
0 \\
\end{array}$ & $\begin{array}{r}1300 \\
122 \\
32 \\
34545 \\
21 \\
7 \\
6 \\
8\end{array}$ & \begin{tabular}{|r|}
7780 \\
808 \\
1702 \\
124 \\
22 \\
18 \\
no sampie \\
no sampie \\
\end{tabular} & $\begin{array}{r}2820 \\
37 \\
196 \\
188 \\
31 \\
604 \\
6 \\
22\end{array}$ & \begin{tabular}{|r|}
208571 \\
64 \\
18793 \\
101765 \\
13676 \\
149375 \\
23043 \\
ary
\end{tabular} & $\begin{array}{r}14801183 \\
51966667 \\
11424333 \\
275439 \\
46152 \\
44295833 \\
76686 \\
3525\end{array}$ & $\begin{array}{r}9402776 \\
4627836 \\
807668 \\
420.0208 \\
5084108 \\
5840258 \\
1037982 \\
6850503 \\
\end{array}$ \\
\hline $\begin{array}{l}2 . \\
3 . \\
4 . \\
5_{n} \\
6 .\end{array}$ & $\begin{array}{l}\text { no sample } \\
\text { no sample } \\
\text { no sample } \\
\text { no sample } \\
\text { no sample } \\
\text { no sample } \\
\text { no sample } \\
\text { no sample } \\
\text { no sample }\end{array}$ & $\begin{array}{l}16 \\
28 \\
23 \\
23\end{array}$ & $\begin{array}{l}26 \\
33 \\
26 \\
16 \\
24 \\
50 \\
36 \\
14\end{array}$ & $\begin{array}{l}\text { dy } \\
\text { dy } \\
\text { dry } \\
\text { dy }\end{array}$ & $\begin{array}{l}\text { Iracer } \\
\text { Iracee } \\
\text { iracer } \\
\text { traces } \\
\text { tracer } \\
\text { tracer } \\
\text { iracer } \\
\text { iracer } \\
\text { iracer }\end{array}$ & 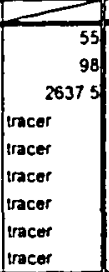 & \begin{tabular}{|r}
316666667 \\
44 \\
46375 \\
2637 \\
26 \\
16333333 \\
20 \\
30333333 \\
22 \\
10666667
\end{tabular} & 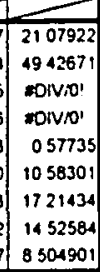 \\
\hline $\begin{array}{l}v_{n} \\
v_{m} \\
\text { vis }\end{array}$ & $\begin{array}{l}\text { no sample } \\
\text { no sample } \\
\text { no sample } \\
\text { no sample } \\
\text { no sample } \\
\text { no sample } \\
\text { no sample } \\
\text { no sample }\end{array}$ & $\begin{array}{r}2 \\
588 \\
1 \\
1\end{array}$ & $\begin{array}{l}\text { Iracer } \\
\text { tracer } \\
\text { tracer } \\
\text { tracer } \\
\text { tracer } \\
\text { tracer } \\
\text { tracer } \\
\text { tracer }\end{array}$ & $\begin{array}{l}12 \\
20 \\
37\end{array}$ & $\begin{array}{l}23 \\
48 \\
22 \\
24\end{array}$ & $\begin{array}{r}29 \\
61 \\
82 \\
32 \\
12879 \\
30 \\
25 \\
25\end{array}$ & $\begin{array}{r}15 \\
3525 \\
3575 \\
155 \\
24159667 \\
1475 \\
1225 \\
29666667\end{array}$ & $\begin{array}{l}1296148 \\
2555223 \\
3304921 \\
1482116 \\
3060131 \\
1198263 \\
1203813 \\
6429101\end{array}$ \\
\hline
\end{tabular}


Table B-9 Sample TP Concentrations (2003)

\begin{tabular}{|c|c|c|c|c|c|c|c|c|c|c|c|c|c|c|c|}
\hline ile & & & & & & & 1. Aug.03 & Aug. 03 & LSep.03 & $3 \cdot \operatorname{sep}-03$ & $7.0 \mathrm{al}-0.03$ & 21.0ct-03 & $4 \cdot \mathrm{Nov} 03$ & Average & to Dev \\
\hline & & & & & & & & & & & & & & & \\
\hline & $\begin{array}{l}121.581 \\
13.125 \\
16.731 \\
15.829 \\
20.337 \\
16.216 \\
12.481 \\
9647 \\
\end{array}$ & $\begin{array}{r}16.09 \\
25.88 \\
15.48 \\
18.54 \\
15.36 \\
13.64 \\
\text { sample }\end{array}$ & $\begin{array}{r}75.009 \\
65.396 \\
26.921 \\
11.531 \\
0.808 \\
10.584 \\
12.123 \\
11.531 \\
\end{array}$ & \begin{tabular}{|r|}
120.974 \\
17.751 \\
24.122 \\
11.255 \\
13.629 \\
11.63 \\
6.758 \\
no sample \\
\end{tabular} & \begin{tabular}{|r}
110.716 \\
20.205 \\
22.367 \\
17.64 \\
18.62 \\
13.716 \\
no sample \\
no sample
\end{tabular} & $\begin{array}{l}115.994 \\
18.652 \\
19.021 \\
19695 \\
21.789 \\
14581 \\
10808 \\
11.639 \\
\end{array}$ & \begin{tabular}{|r|}
88461 \\
no sample \\
24.072 \\
25.582 \\
28.35 \\
21.052 \\
18.2838 \\
182036 \\
\end{tabular} & $\begin{array}{r}96.559 \\
\text { no sample } \\
31.962 \\
\text { no sample } \\
\text { no sample } \\
19.649 \\
\text { no sample } \\
\text { no sample }\end{array}$ & \begin{tabular}{|r|}
451.029 \\
no sample \\
38.904 \\
33697 \\
34.193 \\
18691 \\
17.451 \\
15715 \\
\end{tabular} & $\begin{array}{r}79.5283 \\
\text { no } 58 \mathrm{mpte} \\
38.2547 \\
32.9481 \\
34.1274 \\
20.9784 \\
18.1360 \\
209784 \\
\end{array}$ & \begin{tabular}{|c|} 
outlier \\
no sample \\
42.4551 \\
38.0724 \\
32.5543 \\
24.1764 \\
20.0302 \\
17.8942 \\
\end{tabular} & \begin{tabular}{|r|}
31.1136 \\
no sample \\
11.7366 \\
10.1423 \\
20.8892 \\
20.4480 \\
11.9868 \\
13.5811 \\
\end{tabular} & $\begin{array}{r}05277 \\
0 \text { sample } \\
0.127 \\
0.2133 \\
1.4507 \\
0.8434 \\
0.9527 \\
0.637 \\
\end{array}$ & $\begin{array}{r}116.9912 \\
27.6186 \\
25.4852 \\
1947783 \\
20.97733 \\
1597401 \\
1301701 \\
1378218 \\
\end{array}$ & $\begin{array}{r}1233665 \\
21.17057 \\
11.91903 \\
11.42244 \\
10.70051 \\
6.348454 \\
591275 \\
626967 \\
\end{array}$ \\
\hline & & & & & & & -1 & 12 & & -2 & & $\longrightarrow$ & 2 & $\longrightarrow$ & $\longrightarrow$ \\
\hline $\begin{array}{l}\text { ter } \\
\text { diment } \\
\text { ter } \\
\text { diment } \\
\text { timer } \\
\text { diment } \\
\text { ter } \\
\text { diment } \\
\text { ter } \\
\text { dument } \\
\text { ter } \\
\text { tirnent } \\
\text { der } \\
\text { dirnent } \\
\text { ter } \\
\text { dirnent }\end{array}$ & $\begin{array}{l}\text { ample } \\
\text { ample } \\
\text { ample } \\
\text { ample } \\
\text { ample } \\
\text { ample } \\
\text { ample } \\
\text { ample } \\
\text { ample } \\
\text { ample } \\
\text { ample } \\
\text { ample } \\
\text { ample } \\
\text { ample } \\
\text { ample } \\
\text { ample } \\
\text { ample } \\
\text { ample }\end{array}$ & \begin{tabular}{|r|}
12.596 \\
no sample \\
43.25 \\
no sample \\
no sample \\
no sample \\
26.49 \\
26.49 \\
no sample \\
32.24 \\
no sample \\
4658 \\
no sample \\
3077 \\
no sample \\
23.92 \\
no sample \\
17.44 \\
no sample \\
\end{tabular} & \begin{tabular}{|r|}
9.046 \\
no sample \\
7.287 \\
no sample \\
18.585 \\
no sample \\
9675 \\
no sample \\
12.065 \\
no sample \\
8.167 \\
no sample \\
147 \\
no sample \\
10805 \\
no sample \\
10679 \\
no sample \\
\end{tabular} & 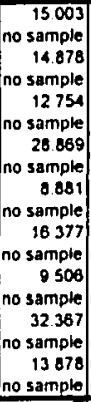 & \begin{tabular}{|r|}
14.488 \\
no sample \\
17084 \\
no sample \\
16587 \\
no sample \\
17.115 \\
no sample \\
22878 \\
no sample \\
20297 \\
no sample \\
19081 \\
no sample \\
13901 \\
no sample \\
no sample \\
no sample
\end{tabular} & $\begin{array}{r}18.098 \\
7.763 \\
20712 \\
5458 \\
12992 \\
10.001 \\
13484 \\
8809 \\
21.02 \\
12092 \\
15637 \\
358 \\
20712 \\
6102 \\
20.521 \\
12.408 \\
\text { eval } \\
17913 \\
\end{array}$ & \begin{tabular}{|r|}
28.17 \\
078 \\
27.512 \\
no sample \\
20.853 \\
1.109 \\
27.018 \\
16311 \\
31.125 \\
no sample \\
29.618 \\
no eval \\
34.25 \\
4599 \\
$32: 21$ \\
17.669 \\
23.726 \\
no eval \\
\end{tabular} & $\mid \begin{array}{r}\text { no sample } \\
1.9 \\
\text { no sample } \\
1.1 \\
\text { no sample } \\
1.644 \\
\text { no sample } \\
\text { no sample } \\
\text { no sample } \\
5578 \\
\text { no sample } \\
048 \\
\text { no sample } \\
1676 \\
\text { no sample } \\
31.323 \\
\text { no sample } \\
17731 \\
\end{array}$ & $\begin{array}{r}23.333 \\
3.571 \\
2863 \\
2.207 \\
26.506 \\
5.43 \\
26258 \\
4.314 \\
30228 \\
11629 \\
26506 \\
2.703 \\
35805 \\
4.314 \\
27746 \\
14107 \\
25886 \\
30102 \\
\end{array}$ & 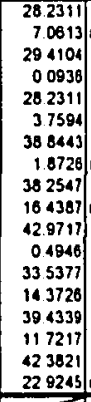 & \begin{tabular}{|c|}
29.7902 \\
no eval \\
34.1877 \\
0.239 \\
32.3031 \\
7.9684 \\
33.5595 \\
no eval \\
51.7779 \\
no eval \\
35.442 \\
0.2566 \\
34.1677 \\
1.7364 \\
49.285 \\
19.1104 \\
38.5852 \\
no eval \\
\end{tabular} & \begin{tabular}{|c|} 
no sample \\
no sample \\
no sample \\
no sample \\
no sample \\
no sample \\
no sample \\
no sample \\
no sample \\
no sample \\
no sample \\
no sample \\
no sample \\
no sample \\
no sample \\
no sample \\
no sample \\
no sample \\
\end{tabular} & $\begin{array}{l}\text { no sample } \\
\text { no sample } \\
\text { no sample } \\
\text { no sample } \\
\text { no sample } \\
\text { no sample } \\
\text { no sample } \\
\text { no sample } \\
\text { no sample } \\
\text { no sample } \\
\text { no sample } \\
\text { no sample } \\
\text { no sample } \\
\text { no sample } \\
\text { no sample } \\
\text { no sample } \\
\text { no sample } \\
\text { no sample }\end{array}$ & $\begin{array}{r}19.6617 \\
121506 \\
2455012 \\
181912 \\
21.6014 \\
51353 \\
24.59031 \\
732665 \\
2758507 \\
1165043 \\
2686399 \\
149904 \\
2585604 \\
54666667 \\
27.78668 \\
17.72318 \\
2465376 \\
22.16763 \\
\end{array}$ & $\begin{array}{r}7.705035 \\
3.092851 \\
100474 \\
2.200493 \\
7679476 \\
3.705498 \\
9459852 \\
5471174 \\
1322035 \\
4531441 \\
1303158 \\
1.533786 \\
9933498 \\
4692224 \\
12.17412 \\
7269499 \\
1207068 \\
5811272 \\
\end{array}$ \\
\hline & & & 21 & 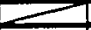 & & & & & & & 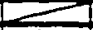 & & & & 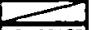 \\
\hline $\begin{array}{l}\text { nent } \\
\text { or } \\
\text { inent } \\
\text { of } \\
\text { or } \\
\text { or } \\
\text { lor } \\
\text { liment } \\
\text { der } \\
\text { diment } \\
\text { or }\end{array}$ & & \begin{tabular}{|r|}
6.79 \\
no sample \\
02.24 \\
no sample \\
075 \\
no sample \\
9.12 \\
12.17 \\
014 \\
9.36 \\
no sample \\
9.12 \\
no sample \\
6.18 \\
no sample \\
\end{tabular} & \begin{tabular}{|r|}
134446 \\
no sample \\
17716 \\
no sample \\
4021 \\
no sample \\
7.413 \\
14.7 \\
16.459 \\
12.313 \\
no sample \\
20.983 \\
no sample \\
12.187 \\
no sampic
\end{tabular} & $\begin{array}{r}11.255 \\
\text { no sample } \\
10 \text { oos } \\
\text { no sample } \\
7.382 \\
\text { no sample } \\
9.131 \\
10008 \\
12004 \\
10131 \\
\text { no sample } \\
8392 \\
\text { no sample } \\
7008 \\
\text { no sample } \\
\end{array}$ & \begin{tabular}{|r}
9915 \\
no sample \\
11955 \\
no sample \\
12047 \\
no sample \\
6825 \\
11955 \\
13407 \\
4354 \\
no sample \\
13098 \\
no sample \\
15500 \\
no sample
\end{tabular} & \begin{tabular}{rr|}
16 & 16 \\
4 & 995 \\
9 & 393 \\
6 & 81 \\
4 & 472 \\
14 & 838 \\
14 & 888 \\
10 & 562 \\
8 & 378 \\
14 & 592 \\
9 & 393 \\
10 & 039 \\
6 & 336 \\
9 & 824 \\
4 & 472
\end{tabular} & \begin{tabular}{|l|} 
ever \\
17.701 \\
7694 \\
18154 \\
12961 \\
20269 \\
17043 \\
15134 \\
2152 \\
eval \\
19448 \\
5.704 \\
19202 \\
45 \\
\end{tabular} & \begin{tabular}{|c|c|}
1853 \\
no eval \\
18451 \\
1.196 \\
15.908 \\
12294 \\
1789 \\
1853 \\
15972 \\
17419 \\
no eval \\
17.731 \\
4362 \\
17731 \\
5801 \\
$\mid$
\end{tabular} & $\begin{array}{c}22.539 \\
\text { eval } \\
15348 \\
1706 \\
17828 \\
17899 \\
22787 \\
21.175 \\
15 \\
22167 \\
2 \text { eval } \\
19688 \\
2847 \\
19088 \\
4180 \\
\end{array}$ & $\begin{array}{rl}20 & 2123 \\
4 & 217 \\
16 & 4387 \\
14 & 0189 \\
16 & 4387 \\
40 & 2453 \\
18.7972 \\
16 & 8745 \\
18 & 0896 \\
22 & 3349 \\
21 & 6839 \\
21 & 7453 \\
10 & 7241 \\
19 & 033 \\
4 & 7028\end{array}$ & \begin{tabular}{|c|}
23.131 \\
no eval \\
197387 \\
no eval \\
23508 \\
11.989 \\
241362 \\
24.1362 \\
ouller \\
24.7644 \\
1.6862 \\
253928 \\
1.4712 \\
27.2773 \\
67622 \\
\end{tabular} & $\mid \begin{array}{c}17.8685 \\
\text { no eval } \\
170101 \\
\text { no sample } \\
182364 \\
94886 \\
15.1705 \\
19.2176\end{array}$ & \begin{tabular}{|l|} 
no sample \\
no sample \\
no sample \\
no sample \\
no sample \\
no sample \\
no sample \\
no sample \\
no sample \\
no s ample \\
no sample \\
no sample \\
no sample
\end{tabular} & $\begin{array}{r}1598446 \\
4606 \\
1463614 \\
628498 \\
13.15865 \\
1278784 \\
15.1279 \\
1601539 \\
141288 \\
1599613 \\
1092103 \\
1665893 \\
525405 \\
1574312 \\
5070667\end{array}$ & $\begin{array}{l}0550129 \\
3779364 \\
5218699 \\
6284754 \\
2.7864 \\
6228323 \\
4577043 \\
3658673 \\
6486635 \\
t 008604 \\
5671991 \\
3233342 \\
6369125\end{array}$ \\
\hline & & & & & & & & & & & & & & & \\
\hline $\begin{array}{l}\text { Jiment } \\
\text { der } \\
\text { dument } \\
\text { ater } \\
\text { dirment } \\
\text { ater } \\
\text { diment } \\
\text { ter } \\
\text { diment } \\
\text { ater } \\
\text { diment } \\
\text { taler } \\
\text { ediment } \\
\text { Valer }\end{array}$ & $\begin{array}{l}\text { sample } \\
\text { sample } \\
\text { sample } \\
\text { sample } \\
\text { sample } \\
\text { samplo } \\
\text { sample } \\
\text { samplo } \\
\text { sample } \\
\text { sample } \\
\text { sample } \\
\text { sample } \\
\text { sample } \\
\text { sample } \\
\text { sample } \\
\text { sample }\end{array}$ & \begin{tabular}{|r|}
1 \\
no sample \\
948 \\
no sample \\
98 \\
no sample \\
899 \\
899 \\
no sample \\
8.5 \\
no sample \\
7.4 \\
no sample \\
581 \\
no sample \\
667
\end{tabular} & \begin{tabular}{|r|}
11.308 \\
no sample \\
84418 \\
no sample \\
92925 \\
no sample \\
12.313 \\
no sample \\
11.811 \\
no sumple \\
7.79 \\
no sample \\
10805 \\
no sample \\
18218 \\
no sample
\end{tabular} & $\begin{array}{r}45 \\
\text { samp } \\
80\end{array}$ & $\left\{\begin{array}{l}\text { no sample } \\
\text { no sample } \\
\text { no sample } \\
\text { no sample } \\
\text { no sample } \\
\text { no sample } \\
\text { no sample } \\
\text { no sample } \\
\text { no sample } \\
\text { no sample } \\
\text { no sample } \\
\text { no sample }\end{array}\right.$ & 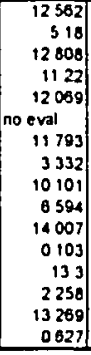 & $\begin{array}{c}1901 \\
15331 \\
20632 \\
2788 \\
23825 \\
0 \text { eval } \\
18557 \\
0 \text { eval } \\
22.197 \\
1417 \\
2092 \\
0 \text { eval } \\
18397 \\
3544\end{array}$ & $\mid \begin{array}{r}\text { no sample } \\
10247 \\
\text { no sample } \\
20609 \\
\text { no sample } \\
1004 \\
\text { no sample } \\
5354 \\
\text { no sample } \\
13221 \\
\text { no sample } \\
1812 \\
\text { no sample } \\
1036 \\
\text { no sample }\end{array}$ & $\begin{array}{r}287 \\
188 \\
172 \\
186 \\
18 \\
173 \\
74 \\
152 \\
128 \\
175 \\
68 \\
158 \\
86 \\
198 \\
42\end{array}$ & $\begin{array}{r}930898 \\
197972 \\
129575 \\
186179 \\
180283 \\
998915 \\
100283 \\
21085 \\
209784 \\
127689 \\
162594 \\
110708 \\
174387 \\
0942 \\
0\end{array}$ & 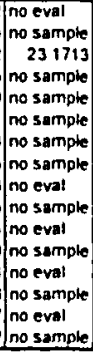 & $\begin{array}{r}198357 \\
126 \\
175055 \\
15298 \\
198357 \\
13944 \\
143169 \\
21756 \\
173829 \\
6836 \\
189772 \\
30341 \\
170149 \\
54623 \\
172802\end{array}$ & $\begin{array}{l}\text { no sa } \\
\text { no sa } \\
\text { nosa } \\
\text { no sa }\end{array}$ & $\begin{array}{l}092 \\
364 \\
642 \\
097 \\
051 \\
778 \\
242 \\
078 \\
395 \\
727 \\
915 \\
541 \\
522\end{array}$ & $\begin{array}{l}5662050 \\
3281155 \\
5348540 \\
0773972 \\
5936839 \\
3107051 \\
436986 \\
4719849 \\
6669200 \\
4749601 \\
508702 \\
4218067 \\
4343898 \\
1420197\end{array}$ \\
\hline
\end{tabular}

Table B-10 Sample TP Concentrations (2004)

\begin{tabular}{|c|c|c|c|c|c|c|c|c|}
\hline Date & $25-$ Mar 04 & 9.Jum-on & $23-\sqrt{\text { Jun-04 }}$ & G-Sut-04 & $20 . \sqrt{u t-0.9}$ & 4.Aug-04 & Average & Sid Dev \\
\hline & & & & & & & & \\
\hline $\begin{array}{l}\text { Lagoon } \\
\text { Exercuse nunort } \\
\text { Faculiative Pond } \\
\text { Cell I influent } \\
\text { Cel } 2 \text { nfluent } \\
\text { Cell } 3 \text { influenl } \\
\text { Cell } 3 \text { etnuent } \\
\text { Finer Sinp Runor }\end{array}$ & $\begin{array}{r}7159 \\
928 \\
12.19 \\
2689 \\
9.25 \\
016 \\
939 \\
1042 \\
\end{array}$ & $\begin{array}{r}71.95 \\
837 \\
1271 \\
18.19 \\
11.54 \\
922 \\
1619 \\
17.35 \\
\end{array}$ & $\begin{array}{rl}50 & 978 \\
24 & 043 \\
13 & 123 \\
13 & 24 \\
13 & 709 \\
11 & 484 \\
1 & 907 \\
10 & 429\end{array}$ & $\begin{array}{l}69731 \\
10063 \\
16840 \\
16: 51 \\
10012 \\
12437 \\
\text { no sample } \\
\text { no sample }\end{array}$ & $\begin{array}{lll}84 & 70 \\
12 & 98 \\
15 & 52 \\
15 & 11 \\
12 & 89 \\
13 & 37 \\
12 & 17 \\
8 & 34 \\
\end{array}$ & $\begin{array}{r}55719 \\
10.78 \\
1089 \\
12.685 \\
10.092 \\
12.918 \\
8487\end{array}$ & $\begin{array}{r}67.459667 \\
13922687 \\
13.546833 \\
16.741 \\
11.382187 \\
11.4315 \\
110248 \\
1103475 \\
\end{array}$ & \begin{tabular}{|l|}
1226549 \\
6047825 \\
2216789 \\
5169032 \\
1638098 \\
1.845627 \\
3228419 \\
393484 \\
\end{tabular} \\
\hline & & & & 1 & $\longrightarrow$ & $=$ & 2 & $\square$ \\
\hline $\begin{array}{l}1 . \\
2 . \\
3 . \\
5 . \\
5 . \\
5 . \\
9 .\end{array}$ & $\begin{array}{l}\text { no sample } \\
\text { no sample } \\
\text { no sample } \\
\text { no sample } \\
\text { no sample } \\
\text { no sample } \\
\text { no sample } \\
\text { no sample } \\
\text { no sample }\end{array}$ & $\begin{array}{r}2548 \\
8.36 \\
22 \\
12.71 \\
30.15\end{array}$ & 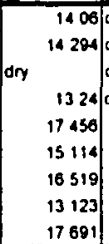 & $\begin{aligned} d y \\
d y \\
d y \\
d y y \\
14.750 \\
1325 \\
14178 \\
11.741 \\
10937\end{aligned}$ & $\begin{array}{l}\text { iracer } \\
\text { uacer } \\
\text { tracer } \\
\text { tracer } \\
\text { tracer } \\
\text { iracet } \\
\text { tracer } \\
\text { traces } \\
\text { tracer }\end{array}$ & \begin{tabular}{|l|}
14753 \\
13.176 \\
21757 \\
iracer \\
iracer \\
iracer \\
iracer \\
iracer \\
Iracer
\end{tabular} & $\begin{array}{r}11711 \\
14.166667 \\
21.757 \\
1324 \\
10231667 \\
12241333 \\
17565667 \\
12524667 \\
22259333 \\
\end{array}$ & 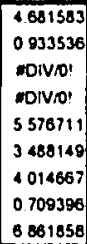 \\
\hline & $\longrightarrow$ & $=$ & $=$ & & $\longrightarrow$ & 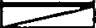 & $\longrightarrow$ & $\longrightarrow$ \\
\hline & sample & 0.81 & Iracer & 6.634 & 9.78 & 801 & 84585 & 1.319301 \\
\hline 4 & no sample & 10.67 & iracer & 10812 & 11.60 & o 514 & 10.4215 & 1.340307 \\
\hline ib & no sample & 1904 & tracer & 12786 & 1848 & 10018 & 14.731 & $3756: 63$ \\
\hline v. & no sample & 16.72 & Iracer & 7.705 & 11.83 & 12307 & 12.208 & 3648837 \\
\hline 1. & no sample & 20.18 & tracer & 9536 & dry & 13.178 & 14300667 & 5.41539 \\
\hline A. & no sample & 10.44 & tracert & 5706 & 12.85 & 8204 & 9.25 & 2.979382 \\
\hline$t_{n}$, & no samplo & 12.3 & tracer & 8.143 & 11.45 & 9.375 & 10.317 & $t 899966$ \\
\hline $\mathrm{ALS}_{\mathrm{S}}$ & no sample & $d y$ & tracer & 491 & 1241 & 9.136 & 10012333 & 2.101335 \\
\hline
\end{tabular}


Table B-II Sample Ammonia Concentrations (2003)

\begin{tabular}{|c|c|c|c|c|c|c|c|c|c|c|c|c|c|c|c|}
\hline 810 & 21.Maу-03 & 4.Jun-03 & 17. Junt-03 & 2-Jur-03 & 15-Jut-03 & 29.Jut-03 & 1. Aug.03 & 26-Aug-03 & 9.5ep-03 & 23-Sep-03 & 7.0ct.03 & 21.001 .03 & 4-Now 03 & iverage & 4d. Dev \\
\hline & & & & & & & & & & & & & & & \\
\hline $\begin{array}{l}\text { Inoff } \\
\text { Pond } \\
\text { ent } \\
\text { ent } \\
\text { ent } \\
\text { ent } \\
\text { Runoft }\end{array}$ & $\begin{array}{r}170.698 \\
5.874 \\
18.348 \\
4.547 \\
10.671 \\
1.438 \\
0.178 \\
0.194\end{array}$ & \begin{tabular}{|r|} 
no sample \\
31.92 \\
17.26 \\
2.14 \\
7.61 \\
0.4 \\
0.49 \\
no sample \\
\end{tabular} & $\begin{array}{r}239.54 \\
16.24 \\
4.68 \\
2.92 \\
7.16 \\
0.59 \\
0.29 \\
0.27 \\
\end{array}$ & \begin{tabular}{|r|}
441.35 \\
9.32 \\
5.37 \\
4.24 \\
2.01 \\
0.64 \\
0.51 \\
no sample \\
\end{tabular} & \begin{tabular}{|r|}
511.97 \\
7.32 \\
11.01 \\
12.45 \\
1.37 \\
1.12 \\
no sampie \\
no sampie
\end{tabular} & $\begin{array}{r}14.49 \\
7.26 \\
8.54 \\
15.09 \\
322 \\
0.95 \\
1.37 \\
\end{array}$ & \begin{tabular}{|r|}
292.58 \\
no sample \\
4.78 \\
12.83 \\
21.9 \\
1002 \\
3.17 \\
3.73 \\
\end{tabular} & \begin{tabular}{|r|}
288.77 \\
no sample \\
22.58 \\
no sample \\
no sample \\
10.97 \\
no sample \\
no sample
\end{tabular} & 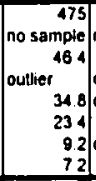 & \begin{tabular}{|r}
437 \\
no sample \\
93.4 \\
outher \\
outlier \\
38.3 \\
outlier \\
19.8 \\
\end{tabular} & \begin{tabular}{|l}
306.23 \\
no sample \\
outtier \\
outlier \\
0.77 \\
31.25 \\
1065 \\
055 \\
\end{tabular} & \begin{tabular}{|r|}
249.11 \\
no sample \\
85.01 \\
10 \\
25.64 \\
24.57 \\
14.08 \\
17.45
\end{tabular} & \begin{tabular}{|r|}
250.15 \\
no sample \\
50.49 \\
5.81 \\
19.49 \\
18.67 \\
8.21 \\
7.21 \\
\end{tabular} & \begin{tabular}{r|}
358.188 \\
15.858 \\
31.65636 \\
7.36625 \\
13.584 \\
13.59583 \\
5.283333 \\
7.1975 \\
\end{tabular} & $\begin{array}{l}104.69 \\
9.69062 \\
326868 \\
4.1967 \\
11.6717 \\
13.3429 \\
529181 \\
7.57910\end{array}$ \\
\hline & & & & & & & & 6 & & & & & & & \\
\hline $\begin{array}{l}\text { Valer } \\
\text { ediment } \\
\text { later } \\
\text { ediment } \\
\text { valer } \\
\text { edunent } \\
\text { later } \\
\text { ediment } \\
\text { taler } \\
\text { ediment } \\
\text { tater } \\
\text { ediment } \\
\text { later } \\
\text { ediment } \\
\text { later } \\
\text { ediment } \\
\text { later } \\
\text { ediment }\end{array}$ & $\begin{array}{c}\text { no sample } \\
\text { no sample } \\
\text { no sample } \\
\text { no sample } \\
\text { no sample } \\
\text { no sample } \\
\text { no sample } \\
\text { no sample } \\
\text { no sampie } \\
\text { no sample } \\
\text { no sample } \\
\text { no sample } \\
\text { no sample } \\
\text { no sample } \\
\text { no sample } \\
\text { no sample } \\
\text { no sample } \\
\text { no sample }\end{array}$ & $\begin{array}{r}14.06 \\
\text { no sample } \\
11 \\
11 \\
\text { no sample } \\
\text { no sample } \\
\text { no sample } \\
20.34 \\
\text { no sample } \\
18.57 \\
\text { no sample } \\
8.26 \\
\text { no sample } \\
7.92 \\
\text { no sample } \\
12.96 \\
\text { no sample } \\
11.06 \\
\text { no sample }\end{array}$ & $\begin{array}{r}10.94 \\
\text { no sample } \\
11.39 \\
\text { no sample } \\
12.84 \\
124 \\
\text { no sample } \\
13.36 \\
\text { no sample } \\
11.38 \\
\text { no sample } \\
10.51 \\
\text { no sample } \\
933 \\
\text { no sample } \\
13.36 \\
\text { no sample } \\
80.27 \\
\text { no sample } \\
\end{array}$ & $\begin{array}{r}18.82 \\
\text { no sample } \\
2048 \\
\text { no sample } \\
28.97 \\
\text { no sample } \\
39.99 \\
\text { no sample } \\
2897 \\
\text { no sample } \\
19.69 \\
\text { no sampie } \\
11 . \\
\text { no sample } \\
22.15 \\
\text { no sample } \\
1555 \\
\text { no sample } \\
\end{array}$ & \begin{tabular}{|r|}
12.45 \\
no sample \\
14.07 \\
no sample \\
17.98 \\
no sample \\
28.18 \\
no sample \\
23.93 \\
no sample \\
14.68 \\
no sample \\
21.17 \\
no sample \\
10.57 \\
no sample \\
no sample \\
no sample
\end{tabular} & $\begin{array}{r}5.71 \\
39.99 \\
\text { eval } \\
55.35 \\
14.49 \\
55.35 \\
16.36 \\
28.9 \\
21.75 \\
1231 \\
12.82 \\
35.41 \\
17.75 \\
51.03 \\
109 \\
3264 \\
927 \\
301 \\
01\end{array}$ & \begin{tabular}{|r|}
12.31 \\
24.75 \\
16.42 \\
no sample \\
15.78 \\
2804 \\
1451 \\
20.17 \\
1783 \\
no sample \\
2017 \\
no eval \\
1936 \\
3305 \\
1936 \\
34.44 \\
1002 \\
2017 \\
\end{tabular} & 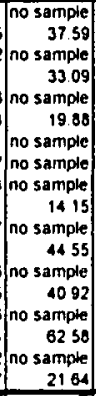 & \begin{tabular}{|r|}
28.9 \\
45.6 \\
25.7 \\
54 \\
42.7 \\
47. \\
43.1 \\
no eval \\
39.8 \\
46 \\
40.4 \\
49.2 \\
44 \\
58.5 \\
49.1 \\
47.7 \\
39.1 \\
40.8 \\
\end{tabular} & \begin{tabular}{|r|}
28.5 \\
38.7 \\
outluer \\
57 \\
41.2 \\
602 \\
517 \\
582 \\
outher \\
69 \\
732 \\
651 \\
664 \\
57.9 \\
725 \\
59 \\
outher \\
49
\end{tabular} & 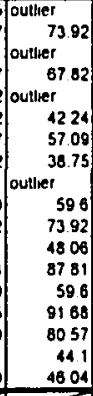 & \begin{tabular}{|l|} 
no sample \\
no sample \\
no sample \\
no sample \\
no sample \\
no sample \\
no sample \\
no sample \\
no sample \\
no sample \\
no sample \\
no sample \\
no sample \\
no sample \\
no sample \\
no sample \\
no sample \\
no sample
\end{tabular} & \begin{tabular}{|l|} 
no sample \\
no sample \\
no sample \\
no sample \\
no sample \\
no sample \\
no sample \\
no sample \\
no sample \\
no sample \\
no sample \\
no sample \\
no simple \\
no sample \\
no sample. \\
no sample \\
no sample \\
no sample
\end{tabular} & $\begin{array}{r}15.96125 \\
43.425 \\
16.51 \\
53452 \\
24.56286 \\
42.135 \\
31.62558 \\
38.505 \\
22.60143 \\
40.212 \\
30.40333 \\
48464 \\
3172667 \\
50.16607 \\
3362 \\
5282167 \\
20.05206 \\
34625 \\
\end{array}$ & $\begin{array}{l}7.90289 \\
16.4414 \\
5.70531 \\
12.6247 \\
12.7230 \\
156179 \\
16.7775 \\
16.3338 \\
9.15495 \\
25.96 \\
28.1910 \\
10.760 \\
28.3358 \\
10.9312 \\
30.2943 \\
18.3018 \\
15.0167 \\
124346 \\
\end{array}$ \\
\hline & & & & & & & & & & & & & & & \\
\hline $\begin{array}{l}\text { ner } \\
\text { diment } \\
\text { jter } \\
\text { diment } \\
\text { dater } \\
\text { edument } \\
\text { fater } \\
\text { ater } \\
\text { tater } \\
\text { Nater } \\
\text { jectiment } \\
\text { Water } \\
\text { Sediment } \\
\text { tater }\end{array}$ & $\begin{array}{l}\text { no sample } \\
\text { no sample } \\
\text { no sample } \\
\text { no sample } \\
\text { no sample } \\
\text { no sample } \\
\text { no sample } \\
\text { no sample } \\
\text { no sample } \\
\text { no sample } \\
\text { no sample } \\
\text { no sample } \\
\text { no sample } \\
\text { no sample } \\
\text { no sample }\end{array}$ & \begin{tabular}{|r|}
0.4 \\
no sample \\
0.35 \\
no sample \\
0.37 \\
no sample \\
0.68 \\
0.51 \\
0.29 \\
0.43 \\
no sample \\
0.41 \\
no sample \\
0.26 \\
no sumple \\
\end{tabular} & \begin{tabular}{|c|}
10.51 \\
no sample \\
4428 \\
no sample \\
4.92 \\
no sample \\
5.55 \\
12.84 \\
1508 \\
1.49 \\
no sample \\
51.08 \\
no sample \\
437 \\
no sample
\end{tabular} & \begin{tabular}{|r|}
6.54 \\
no sample \\
604 \\
no sample \\
2.26 \\
no sample \\
4.24 \\
3.92 \\
459 \\
408 \\
4 no sample \\
4.24 \\
no sample \\
309 \\
no sample \\
\end{tabular} & \begin{tabular}{|r}
1.32 \\
no sample \\
0.58 \\
no sample \\
0.42 \\
no sample \\
0.58 \\
0.42 \\
0.37 \\
0.54 \\
no sample \\
09.95 \\
no sample \\
3.24 \\
no sample \\
\end{tabular} & $\begin{array}{r}224 \\
21.75 \\
1.22 \\
27.5 \\
108 \\
2086 \\
322 \\
168 \\
137 \\
285 \\
2775 \\
1.55 \\
2175 \\
0.61 \\
3264\end{array}$ & \begin{tabular}{|r|r|}
269 \\
11.34 \\
228 \\
1576 \\
1.17 \\
1283 \\
519 \\
289 \\
289 \\
7.59 \\
no ova1 \\
422 \\
1337 \\
587 \\
20.17 \\
\end{tabular} & $\begin{array}{rl}10 & 07 \\
6 & 59 \\
3 & 79 \\
18 & 07 \\
8 & 15 \\
16 & 77 \\
5 & 8 \\
7 & 81 \\
2 & 94 \\
9 & 85 \\
27 & 92 \\
8 & 15 \\
29 & 13 \\
2 & 94 \\
41 & 55\end{array}$ & $\begin{array}{l}319 \\
319 \\
185 \\
218 \\
807 \\
252 \\
168 \\
185 \\
178 \\
128 \\
218 \\
129 \\
198 \\
102 \\
398 \\
\end{array}$ & \begin{tabular}{|r|}
85 \\
no eval \\
332 \\
354 \\
outler \\
358 \\
186 \\
198 \\
142 \\
156 \\
387 \\
16.3 \\
342 \\
17.3 \\
31 \\
\end{tabular} & 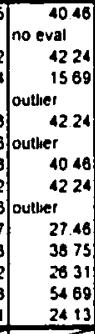 & \begin{tabular}{|c|}
31.78 \\
11.87 \\
33.15 \\
no sample \\
outher \\
31.78 \\
outiver \\
4286 \\
3934 \\
outher \\
no sample \\
41.06 \\
no sample \\
5309 \\
no sample
\end{tabular} & $\begin{array}{l}\text { no sample } \\
\text { no sample } \\
\text { no sample } \\
\text { no sample } \\
\text { no sample } \\
\text { no sample } \\
\text { no sample } \\
\text { no sample } \\
\text { no sample } \\
\text { no sample } \\
\text { no sample } \\
\text { no sample } \\
\text { no sample } \\
\text { no sample } \\
\text { no sample }\end{array}$ & $\begin{array}{r}16.94455 \\
128875 \\
1687545 \\
2200333 \\
3305 \\
2649714 \\
674 \\
13.77182 \\
1274455 \\
6.105558 \\
28.726 \\
16.40818 \\
2409333 \\
14.15091 \\
3204833\end{array}$ & $\begin{array}{r}176800 \\
636742 \\
17.9268 \\
8.0484 \\
330207 \\
10.6201 \\
651800 \\
154008 \\
151825 \\
5.5754 \\
6.13708 \\
18.6107 \\
736685 \\
202307 \\
918205 \\
\end{array}$ \\
\hline & & & & & & & & & & & & & & & -1 \\
\hline $\begin{array}{l}\text { ater } \\
\text { doment } \\
\text { later } \\
\text { ediment } \\
\text { Vater } \\
\text { iediment } \\
\text { Vater } \\
\text { sedurnent } \\
\text { jater } \\
\text { ediment } \\
\text { Vater } \\
\text { etedrnent } \\
\text { Naler } \\
\text { Sediment } \\
\text { Water }\end{array}$ & $\begin{array}{l}\text { no sample } \\
\text { no sample } \\
\text { no sample } \\
\text { no sample } \\
\text { no sample } \\
\text { no sample } \\
\text { no sample } \\
\text { no sample } \\
\text { no sample } \\
\text { no sample } \\
\text { no sample } \\
\text { no sample } \\
\text { no sample } \\
\text { no sample } \\
\text { no sample } \\
\text { no sample }\end{array}$ & $\begin{array}{r}242 \\
\text { no sample } \\
206 \\
206 \\
\text { no sample } \\
0.53 \\
\text { no sample } \\
1.02 \\
\text { no sample } \\
18 \\
\text { no sample } \\
055 \\
\text { no sample } \\
0.37 \\
\text { no sample } \\
0.45 \\
\text { no sample }\end{array}$ & 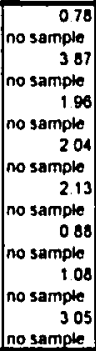 & \begin{tabular}{|r|}
2.64 \\
no sample \\
55 to \\
no sample \\
7.65 \\
no sample \\
177 \\
no sample \\
798 \\
no sample \\
165 \\
no sample \\
254 \\
no sample \\
604 \\
no sample
\end{tabular} & \begin{tabular}{|l} 
no sample \\
no sample \\
no sample \\
no sample \\
no sample \\
no sample \\
no sample \\
no sample \\
no sample \\
no sample \\
no sample \\
no sample \\
no sample \\
no sample \\
no sample
\end{tabular} & $\begin{array}{r}1.9 \\
29 \\
2.85 \\
17 \\
263 \\
2.46 \\
1.75 \\
177 \\
183 \\
155 \\
1.75 \\
091 \\
155 \\
122 \\
336 \\
103\end{array}$ & $\begin{array}{rl}2 & 92 \\
247 \\
751 \\
157 \\
1008 \\
171 \\
85 \\
092 \\
751 \\
v a 1 \\
612 \\
4 \\
48 \\
05 \\
783 \\
145\end{array}$ & \begin{tabular}{|r|r|} 
no sample & 556 \\
50 & $5 a$ mple \\
511 \\
50 \\
nample \\
781 \\
no sample \\
0.97 \\
no sample \\
449 \\
no sample \\
533 \\
no sample \\
079 \\
no sample \\
348
\end{tabular} & $\begin{array}{rl}17 & 8 \\
778 \\
21 & 4 \\
12 & 1 \\
34 & 2 \\
14 & 2 \\
15 & 2 \\
11 \\
104 \\
84 \\
893 \\
0.5 \\
8 \\
965 \\
724 \\
738\end{array}$ & $\begin{array}{l}165 \\
15.1 \\
17.1 \\
171 \\
202 \\
105 \\
145 \\
773 \\
104 \\
721 \\
165 \\
622 \\
152 \\
73 \\
9.75 \\
749\end{array}$ & 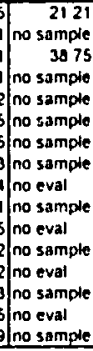 & \begin{tabular}{|c|c|}
2255 \\
9 & 18 \\
3176 \\
807 \\
4106 \\
20.7 \\
2794 \\
7.1 \\
outlier \\
1137 \\
2564 \\
526 \\
20.7 \\
326 \\
outluer \\
8
\end{tabular} & $\begin{array}{l}\text { no sample } \\
\text { no sample } \\
\text { no sample } \\
\text { no sample } \\
\text { no sample } \\
\text { no sample } \\
\text { no sample } \\
\text { no sample } \\
\text { no sample } \\
\text { no sample } \\
\text { no sample } \\
\text { no sample } \\
\text { no sample } \\
\text { no sample }\end{array}$ & $\begin{array}{r}9857778 \\
7.165 \\
1459558 \\
7608333 \\
1408875 \\
9563333 \\
9465 \\
4915 \\
5975714 \\
6604 \\
77525 \\
4703333 \\
678 \\
412 \\
5388571 \\
4876687 \\
\end{array}$ & $\begin{array}{r}93437 \\
462493 \\
13.5011 \\
813337 \\
154633 \\
723338 \\
932363 \\
42694 \\
40117 \\
375231 \\
804678 \\
326943 \\
745443 \\
336254 \\
323543 \\
329277\end{array}$ \\
\hline
\end{tabular}

Table B-12 Sample Ammonia Concentrations (200t)

\begin{tabular}{|c|c|c|c|c|c|c|c|c|}
\hline Dale & 25-May-04 & 9-Jun-04 & $23 \sqrt{u n-04}$ & 6-Jul-04 & 20-Jut-OA & 4.Aug.04 & Average & Sid Dev \\
\hline $\begin{array}{l}\text { Lagoon } \\
\text { Exercise nunoff } \\
\text { Facultaive Pond } \\
\text { Coll } 1 \text { influent } \\
\text { Ceit } 2 \text { influent } \\
\text { Cel } 3 \text { infuent } \\
\text { Cell } 3 \text { effuent } \\
\text { Futer Sing Runoff }\end{array}$ & $\begin{array}{rr} & 213.6 \\
& 1.88 \\
& 0.61 \\
& 0.94 \\
<05 & \\
<05 & \\
<05 & \\
<05 & \\
<05\end{array}$ & 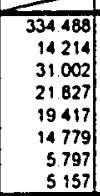 & $\begin{array}{r}44265 \\
3459 \\
6475 \\
138 \\
947 \\
138 \\
1.124 \\
065\end{array}$ & $\begin{array}{r}348.16 \\
4837 \\
36692 \\
16666 \\
1.756 \\
1623 \\
\text { no sample } \\
\text { no sampie }\end{array}$ & $\begin{array}{rr}962 & 79 \\
7 & 81 \\
27 & 86 \\
22 & 2 \\
12 & 3 \\
1.67 \\
0 & 49 \\
0 & 34\end{array}$ & $\begin{array}{r}46442 \\
846 \\
458 \\
47 \\
9.16 \\
386 \\
102\end{array}$ & \begin{tabular}{|r|}
461018 \\
19.220667 \\
35452333 \\
133555 \\
104206 \\
7.1454 \\
210775 \\
2049 \\
\end{tabular} & $\begin{array}{r}261567 \\
1820802 \\
1937159 \\
8834147 \\
6364656 \\
659216 \\
2475119 \\
2696066 \\
\end{array}$ \\
\hline & 1 & & & - & $\angle$ & 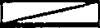 & $\longrightarrow$ & $\longrightarrow$ \\
\hline 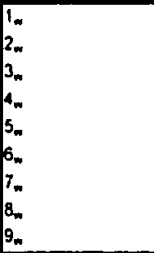 & \begin{tabular}{|l|} 
no samplo \\
no sample \\
no sample \\
no sample \\
no sample \\
no samplo \\
no sample \\
no sample \\
no sample
\end{tabular} & $\begin{array}{|rr|} & 29.817 \\
& 40732 \\
\text { dry } & \\
\text { dry } & \\
& 45.786 \\
26.525 \\
4.588 \\
10.819 \\
14.779 \\
\end{array}$ & $\begin{array}{l}29.27 \\
19.27 \\
14.38 \\
1438 \\
12.17 \\
15.64 \\
14.38 \\
2184\end{array}$ & $\begin{array}{l}\text { dry } \\
d y \\
d y \\
d r y \\
27833 \\
12.149 \\
24725 \\
8.516 \\
18.029\end{array}$ & $\begin{array}{l}\text { iracer } \\
\text { tracer } \\
\text { iracoe } \\
\text { iracer } \\
\text { iracer } \\
\text { iracer } \\
\text { iracer } \\
\text { iracer } \\
\text { iracer }\end{array}$ & \begin{tabular}{|r}
371 \\
2444 \\
$208 B$ \\
tracer \\
tracer \\
racer \\
tracer \\
racer \\
tracer
\end{tabular} & \begin{tabular}{|r}
20.932333 \\
28147333 \\
2088 \\
14.38 \\
29333 \\
16948 \\
14984333 \\
11.238333 \\
18.216
\end{tabular} & \begin{tabular}{|r|}
1491749 \\
11.20101 \\
WDIVO! \\
WDIVIO! \\
15.75664 \\
B 293932 \\
100845 \\
2.954404 \\
3534212 \\
\end{tabular} \\
\hline & - & - & & & & - & - & 2 \\
\hline $\begin{array}{l}v_{m} \\
v_{m} \\
v_{m} \\
\text { vili } \\
\text { vil } \\
\text { vili }\end{array}$ & \begin{tabular}{|l|} 
no samplo \\
no samplo \\
no sample \\
no sample \\
no samplo \\
no samplo \\
no sample \\
no samplo
\end{tabular} & $\begin{array}{l}2.764 \\
5.797 \\
9.624 \\
3.925 \\
2.658 \\
3.359 \\
7.617\end{array}$ & $\begin{array}{l}\text { tracer } \\
\text { iracer } \\
\text { iracer } \\
\text { tracer } \\
\text { iracer } \\
\text { iracer } \\
\text { iracer } \\
\text { iracer }\end{array}$ & $\begin{array}{r}0.766 \\
4.9 \\
9.587 \\
2.056 \\
1.826 \\
1.137 \\
0.797 \\
0.737\end{array}$ & $\begin{array}{l}051 \\
132 \\
5.68 \\
1.99\end{array}$ & $\begin{array}{r}7.83 \\
1.5 \\
261 \\
5.72 \\
3.16 \\
2.32 \\
0.77\end{array}$ & $\begin{array}{r}2.9675 \\
3.37925 \\
6.87525 \\
3.42275 \\
2548 \\
2.0515 \\
2436 \\
2.539\end{array}$ & $\begin{array}{l}3.394664 \\
2.304364 \\
3.392649 \\
1.774861 \\
0.673769 \\
1.009214 \\
3.455624 \\
3.372759\end{array}$ \\
\hline
\end{tabular}


Table B-I3 Sample Nitrate Concentrations (2003)

\begin{tabular}{|c|c|c|c|c|c|c|c|c|c|c|c|c|c|c|c|}
\hline ate & 1-May-03 & 4-Jun-03 & 17.Juneus & $2-\sqrt{6}-03$ & $10-3$ & $29 . J u 1.03$ & 11-Aug.03 & 26.Aug 03 & 9.Sep-03 & $23-S_{e p r} 03$ & $7.0 \mathrm{cc} \cdot 031$ & $21.0 \mathrm{ct.03}$ & 4. Nov. 03 & 3 Average & Sid. Dev. \\
\hline & 2 & - & 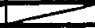 & & - & & $\longrightarrow$ & & 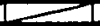 & & -1 & 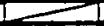 & & & \\
\hline 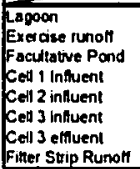 & $\begin{array}{l}2.72 \\
0.71 \\
094 \\
068 \\
062 \\
0.75 \\
071\end{array}$ & \begin{tabular}{|r|} 
no somple \\
0.99 \\
0.92 \\
0.78 \\
0.68 \\
0.75 \\
0.9 \\
no sample
\end{tabular} & \begin{tabular}{|l} 
oubres \\
0.65 \\
1.09 \\
045 \\
048 \\
0.41 \\
0.43 \\
0.88
\end{tabular} & $\begin{array}{r}1.452 \\
7.501 \\
2.214 \\
1.878 \\
1.878 \\
1.505 \\
2925 \\
0 \text { sampie }\end{array}$ & $\begin{array}{r}2.49 \\
1.02 \\
1.16 \\
1.46 \\
1.46 \\
1.27 \\
\text { no sample } \\
\text { no sampic } \\
\end{array}$ & $\begin{array}{l}253 \\
1.06 \\
1.12 \\
1.34 \\
1.19 \\
0.84 \\
0.89\end{array}$ & $\begin{array}{r}4.29 \\
\text { no eval } \\
1.17 \\
1.43 \\
1.32 \\
1.43 \\
1.43 \\
137\end{array}$ & \begin{tabular}{|c|}
1269 \\
no sample \\
1.37 \\
no somple \\
no sample \\
1.69 \\
no sample \\
no sample
\end{tabular} & \begin{tabular}{|r|}
3.59 \\
no sample \\
0.161 \\
0.209 \\
1.05 \\
0.568 \\
0.209 \\
0.39 \\
\end{tabular} & \begin{tabular}{|c|}
0.92 \\
no somple \\
0.464 \\
0.701 \\
0.739 \\
0.345 \\
0.412 \\
0.537 \\
\end{tabular} & \begin{tabular}{|r|r|}
5.86 \\
no sample \\
3.14 \\
0.573 \\
1.55 \\
0.126 \\
0.117 \\
0.03 \\
0 \\
0
\end{tabular} & 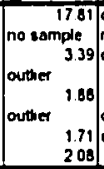 & 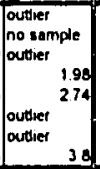 & $\begin{array}{r}6.625778 \\
22442 \\
1.463545 \\
10901 \\
1.360636 \\
08934 \\
1002556 \\
1.260875\end{array}$ & $\begin{array}{r}5511707 \\
2.943188 \\
1.031474 \\
0500743 \\
0.651019 \\
0.54681 \\
0.90088 \\
1.203603\end{array}$ \\
\hline & & & & & & & & & & & & & & & 1 \\
\hline 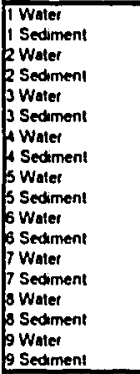 & \begin{tabular}{|c|} 
no somple \\
no sample \\
no sample \\
no sample \\
no sample \\
no sample \\
no sample \\
no sample \\
no sample \\
no sample \\
no sample \\
no sample \\
no semple \\
no sample \\
no sample \\
no semple \\
no sample \\
no sample
\end{tabular} & \begin{tabular}{|r|}
0.71 \\
no sample \\
0.86 \\
no sarmple \\
no sample \\
no sample \\
1.36 \\
no sample \\
0.9 \\
no sample \\
0.86 \\
no somple \\
0 \\
no sample \\
0.71 \\
no sample \\
00.94 \\
no sumple
\end{tabular} & 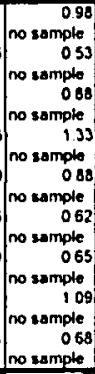 & 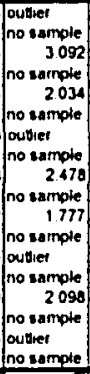 & \begin{tabular}{|r}
1.52 \\
no sample \\
1.9 \\
no sample \\
1.27 \\
no sample \\
0.89 \\
no sample \\
1.74 \\
no sample \\
1.16 \\
no sample \\
111 \\
no sample \\
133 \\
no sample \\
no sample \\
no sample
\end{tabular} & \begin{tabular}{rr|}
1.51 \\
182 \\
10 eval \\
0 \\
072 \\
1 \\
156 \\
16 \\
0.84 \\
084 \\
0.75 \\
1.51 \\
0.78 \\
142 \\
0.75 \\
17 \\
117 \\
1.42 \\
0.78
\end{tabular} & 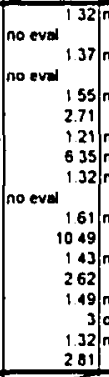 & \begin{tabular}{|c|} 
no sample \\
331 \\
no sample \\
426 \\
no sample \\
391 \\
no sample \\
no somple \\
no sample \\
247 \\
no sample \\
1029 \\
no sample \\
126 \\
no sample \\
Worter \\
no sumple \\
138
\end{tabular} & $\begin{array}{l}0.042 \\
094 \\
0.047 \\
0993 \\
0218 \\
0.914 \\
0334 \\
1.35 \\
0.914 \\
0.449 \\
0.023 \\
3.01 \\
1 \\
131 \\
1.12 \\
107 \\
0375 \\
0.675\end{array}$ & 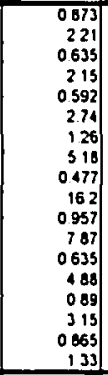 & $\begin{array}{r}0.39 \\
2.53 \\
0.522 \\
1.27 \\
0.939 \\
4.72 \\
0.47 \\
382 \\
0.564 \\
1.73 \\
1.3 \\
652 \\
0 \\
416 \\
0 \\
213 \\
0717 \\
1.9\end{array}$ & 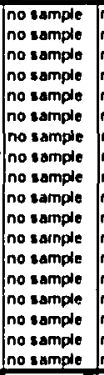 & $\begin{array}{l}\text { no sample } \\
\text { no sample } \\
\text { no sample } \\
\text { no sample } \\
\text { no sample } \\
\text { no sample } \\
\text { no sample } \\
\text { no somple } \\
\text { no sample } \\
\text { no sample } \\
\text { no sample } \\
\text { no sample } \\
\text { no sample } \\
\text { no sample } \\
\text { no sample } \\
\text { no sample } \\
\text { no sample } \\
\text { no sample }\end{array}$ & \begin{tabular}{|r|}
0911875 \\
2.152 \\
1.1195 \\
18766 \\
1.035375 \\
2759 \\
1.05675 \\
3.508 \\
1.123667 \\
43198 \\
1.090778 \\
651 \\
0893125 \\
299657 \\
1.158657 \\
2.104 \\
0002429 \\
35325 \\
\end{tabular} & \begin{tabular}{|c|c|}
0537622 \\
0.875483 \\
0.979762 \\
1435423 \\
0.575531 \\
1.415253 \\
0450554 \\
2.38459 \\
0634218 \\
6589442 \\
0.547463 \\
3.926153 \\
047022 \\
1704731 \\
060588 \\
0.979684 \\
0366763 \\
5009943 \\
\end{tabular} \\
\hline & & & & & & & & & & & & & & - & 1 \\
\hline 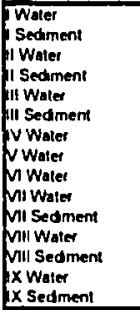 & 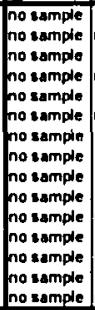 & \begin{tabular}{|r|r|} 
no sarnole \\
0.75 \\
no sample \\
007 \\
no sample \\
0.82 \\
099 \\
0.9 \\
0.94 \\
no sample \\
0.99 \\
no sample \\
103 \\
no sample
\end{tabular} & $\left\{\begin{array}{r}0.5 \\
\text { no somple } \\
062 \\
\text { no sample } \\
023 \\
\text { no sample } \\
05 \\
065 \\
056 \\
0.62 \\
\text { no somple } \\
0.84 \\
\text { no sample } \\
0.84 \\
\text { no sample }\end{array}\right.$ & 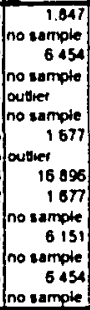 & 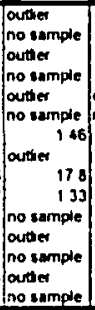 & \begin{tabular}{|r|}
151 \\
699 \\
447 \\
297 \\
297 \\
outres \\
no eval \\
112 \\
5.7 \\
699 \\
095 \\
1143 \\
526 \\
137 \\
823 \\
107 \\
\end{tabular} & 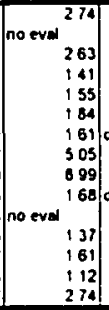 & 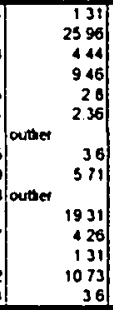 & 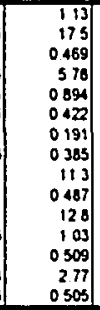 & $\begin{array}{rl}0 & 53 \\
19 & 7 \\
0.339 \\
0.32 \\
0.451 \\
1 & 87 \\
0 & 579 \\
0 & 477 \\
0 & 497 \\
0 & 457 \\
7 & 7 \\
0 & 47 \\
1 & 33 \\
0.425 \\
2 & 18\end{array}$ & \begin{tabular}{r|r|}
0 & 74 \\
21 & 0 \\
0.226 \\
123 \\
0 & 975 \\
1 & 27 \\
0.753 \\
1 & 18 \\
0245 \\
1 & 41 \\
4 & 4 \\
0 & 05 \\
1 & 15 \\
0273 \\
1 & 37 \\
\end{tabular} & \begin{tabular}{|r|}
279 \\
992 \\
241 \\
no sumple \\
229 \\
279 \\
ourder \\
253 \\
229 \\
293 \\
no somple \\
241 \\
no somple \\
198 \\
no sample
\end{tabular} & \begin{tabular}{|l} 
no sample \\
no sample \\
no sample \\
no sample \\
no sample \\
no sample \\
no sample \\
no sumple \\
no sample \\
no ssmple \\
no sample \\
no sample \\
no sample \\
no sample \\
no sample
\end{tabular} & \begin{tabular}{|r|}
139667 \\
16.995 \\
22878 \\
6706667 \\
124625 \\
1758657 \\
0966657 \\
2284667 \\
6379818 \\
12468 \\
9128 \\
22831 \\
1213167 \\
33852 \\
1910833 \\
\end{tabular} & \begin{tabular}{|c|c|}
0833407 \\
7240966 \\
2190284 \\
4101192 \\
0.90048 \\
0833035 \\
0527891 \\
2047768 \\
6475191 \\
0765519 \\
7053529 \\
2164859 \\
0375484 \\
37237 \\
1147965 \\
\end{tabular} \\
\hline & & -1 & & & & & & & & & -1 & 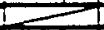 & & $\longrightarrow$ & - \\
\hline 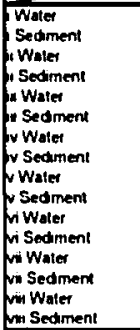 & \begin{tabular}{|c|} 
no sample \\
no sample \\
no sample \\
no sample \\
no semple \\
no sample \\
no smmple \\
ho sample \\
no sample \\
no sample \\
ho sample \\
no sample \\
ho sample \\
no sample \\
no sample \\
no sample
\end{tabular} & 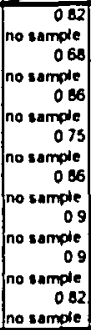 & $\left\{\begin{array}{r}062 \\
\text { no sample } \\
072 \\
\text { no sumple } \\
059 \\
\text { no sample } \\
065 \\
\text { no sample } \\
062 \\
\text { no wimple } \\
065 \\
\text { no sample } \\
072 \\
\text { no smmple } \\
056 \\
\text { no sample }\end{array}\right.$ & $\left\{\begin{array}{r}2098 \\
\text { no sample } \\
\text { outier } \\
\text { no sample } \\
2344 \\
\text { no sample } \\
2098 \\
\text { no sample } \\
2478 \\
248 \\
\text { no } 29 m p l e \\
2344 \\
\text { no sample } \\
2639 \\
\text { no sample } \\
4079 \\
\text { no sample }\end{array}\right.$ & 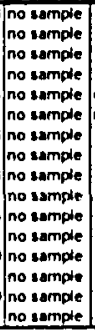 & 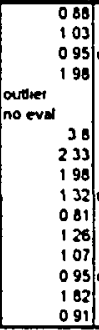 & 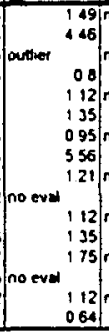 & $\mid \begin{array}{c}\text { no rample } \\
247 \\
\text { no sample } \\
176 \\
\text { no sample } \\
28 \\
\text { no sample } \\
2.47 \\
\text { no sample } \\
3.17 \\
\text { no sample } \\
548 \\
\text { no semple } \\
1439 \\
\text { no sample } \\
257\end{array}$ & $\begin{array}{ccc}0 & 047 \\
0 & 523 \\
0 & 161 \\
0 & 358 \\
0 & 626 \\
0 & 36 \\
0 & 065 \\
0 & 0 & 33 \\
\text { overer } & 0 & \\
0 & 131 \\
0 & 151 \\
1 & 66 \\
0 & 066 \\
0 & 523 \\
0 & 536 \\
0 & 363\end{array}$ & $\begin{array}{rl}0 & 635 \\
1 & 5 \\
0 & 477 \\
1 & 04 \\
0 & 45 \\
1 & 49 \\
0 & 694 \\
1 & 12 \\
175 \\
126 \\
0778 \\
0957 \\
0621 \\
11 \\
094 \\
094\end{array}$ & 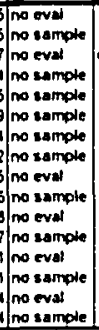 & 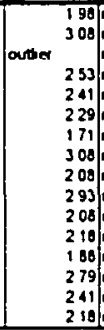 & \begin{tabular}{|l} 
no simple \\
no sample \\
no sample \\
no sample \\
no sample \\
no sample \\
no sample \\
no smmple \\
no sample \\
no sample \\
no sumple \\
no sample \\
no sample \\
no ssmple \\
no sample \\
no sample
\end{tabular} & \begin{tabular}{|r|}
107125 \\
2177167 \\
05976 \\
1411333 \\
112 \\
1658 \\
1339625 \\
2481657 \\
1560286 \\
18222 \\
1104125 \\
2147633 \\
1.20325 \\
39505 \\
1535623 \\
1267167 \\
1
\end{tabular} & \begin{tabular}{|c|}
071695 \\
1.457601 \\
0295277 \\
08114554 \\
0832558 \\
0.935947 \\
1162147 \\
1807821 \\
0685717 \\
1177656 \\
0.740568 \\
1684353 \\
0822615 \\
569928 \\
1213312 \\
0891751 \\
\end{tabular} \\
\hline
\end{tabular}

Table B-1 t Sample Nitrate Concentrations (200t)

\begin{tabular}{|c|c|c|c|c|c|c|c|c|}
\hline Dato & 25-May 04 & 9.Jun.04 & 23 Jun-041 & 6- Jut-04 & 20-Jut-04 & AAug-04 & Average & Sid Dov \\
\hline $\begin{array}{l}\text { Lagoon } \\
\text { Exerase nunoff } \\
\text { Facultative Pond } \\
\text { Coll } 1 \text { influent } \\
\text { Cel } 2 \text { influent } \\
\text { Cell } 3 \text { influent } \\
\text { Cen } 3 \text { etfluent } \\
\text { F Niter Sing Runoff }\end{array}$ & $\begin{array}{l}582 \\
173 \\
125 \\
1.11 \\
166 \\
153 \\
16 \\
23 \\
\end{array}$ & $\begin{array}{ll}11 & 07 \\
0 & 97 \\
0 & 73 \\
0 & 97 \\
1 & 09 \\
1 & 13 \\
1 & 09 \\
0 & 69\end{array}$ & \begin{tabular}{r|r|} 
& 22 \\
1 & 07 \\
0 & 83 \\
0 & 94 \\
0 & 9 \\
0 & 79 \\
0.9 \\
103
\end{tabular} & \begin{tabular}{|r|}
1835 \\
outher \\
0.55 \\
0821 \\
0.789 \\
0758 \\
no sample \\
no sample
\end{tabular} & \begin{tabular}{r|}
47 \\
0.56 \\
041 \\
043 \\
0.4 \\
0.4 \\
0.43 \\
0.4
\end{tabular} & \begin{tabular}{r|}
7.3 \\
195 \\
155 \\
188 \\
161 \\
181 \\
161
\end{tabular} & \begin{tabular}{|r|}
5.32416667 \\
1256 \\
088666667 \\
102516667 \\
107483333 \\
106966667 \\
1126 \\
1.155 \\
\end{tabular} & \begin{tabular}{|l|}
36489018 \\
05716467 \\
04336865 \\
04783599 \\
04892281 \\
05267719 \\
04989289 \\
$0 \quad 8097119$
\end{tabular} \\
\hline 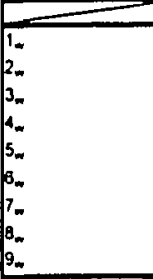 & $\begin{array}{l}\text { no sample } \\
\text { no sample } \\
\text { no sample } \\
\text { no sample } \\
\text { no sample } \\
\text { no sample } \\
\text { no sample } \\
\text { no sample } \\
\text { no sample }\end{array}$ & $\begin{array}{|ll|} & 093 \\
& 073 \\
\text { dry } & \\
\text { dry } & \\
\text { outher } & \\
& 0.73 \\
& 138 \\
\text { outher } & \\
& 1246\end{array}$ & $\begin{array}{l}079 \\
064 \\
067 \\
0.73 \\
067 \\
0.61 \\
07 \\
086\end{array}$ & $\begin{array}{l}0645 \\
0.728 \\
0.699 \\
0699 \\
0.645\end{array}$ & $\begin{array}{l}\text { tracer } \\
\text { tracer } \\
\text { tracer } \\
\text { tracer } \\
\text { tracer } \\
\text { tracer } \\
\text { tracer } \\
\text { tracer } \\
\text { tracer }\end{array}$ & $\begin{array}{|ll|}\text { oudier } & \\
& 123 \\
& 097 \\
\text { tracer } & \\
\text { iracer } & \\
\text { Iracer } & \\
\text { iracer } & \\
\text { Iracer } & \\
\text { Iracer }\end{array}$ & \begin{tabular}{|r|}
086 \\
085666567 \\
097 \\
067 \\
06875 \\
0.70933333 \\
089633333 \\
06995 \\
4655 \\
\end{tabular} & 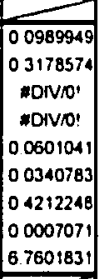 \\
\hline & & 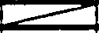 & & & & - & -1 & $\longrightarrow$ \\
\hline 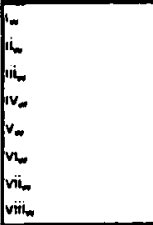 & $\begin{array}{l}\text { no samplo } \\
\text { no sample } \\
\text { no samplo } \\
\text { no sample } \\
\text { no sample } \\
\text { no samplo } \\
\text { no sample } \\
\text { no sample }\end{array}$ & $\begin{array}{r}1.28 \\
1.49 \\
17.05 \\
1.68 \\
1844 \\
1.33 \\
123\end{array}$ & $\begin{array}{l}\text { iracer } \\
\text { tracer } \\
\text { tracer } \\
\text { tracer } \\
\text { tracer } \\
\text { tracer } \\
\text { tracer } \\
\text { tracer }\end{array}$ & $\begin{array}{l}0.965 \\
1.088 \\
1.133 \\
1.004 \\
1.501 \\
0855 \\
1501\end{array}$ & $\begin{array}{l}0.43 \\
0.38 \\
0.52 \\
0.52\end{array}$ & $\begin{array}{l}1.81 \\
161 \\
2.37 \\
1.88 \\
3.11 \\
138 \\
149 \\
127\end{array}$ & $\begin{array}{r}1.12125 \\
1.142 \\
526825 \\
1.271 \\
7.68366667 \\
098625 \\
1.16775 \\
1.21233333 \\
\end{array}$ & $\begin{array}{l}05778751 \\
05548838 \\
78920985 \\
06254204 \\
93499332 \\
0.4683192 \\
0494618 \\
0.446303\end{array}$ \\
\hline
\end{tabular}


Table B-15 Sample TKN Concentrations (2003)

\begin{tabular}{|c|c|c|c|c|c|c|c|c|c|c|c|c|c|c|c|}
\hline Date & $1-$ Mayed & 4-Jun-03 & $17 \sqrt{\mathrm{kin}} \cdot 03$ & 2.Jul.03 & 15-Jut-03 & 29-Jul-0] & 11.Aung.03 & 26-Augt 03 & $9-\operatorname{Sep}-03$ & 23-Sep.03 & $7.0 \mathrm{ct}-0 \mathrm{~J}$ & $21.0 \mathrm{ec1.03}$ & 4-Nov-03 & Average & id. Dev. \\
\hline & & & & & & & & & & & & & & & \\
\hline 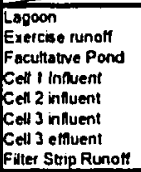 & 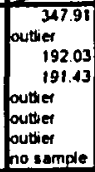 & $\begin{array}{r}\text { no sampio } \\
40.12 \\
45.02 \\
9.49 \\
31.93 \\
10.09 \\
162 \\
\text { no sample } \\
\end{array}$ & $\begin{array}{r}1749.05 \\
68.72 \\
60.63 \\
61.42 \\
44.7 \\
2311 \\
28.16 \\
16 \\
\end{array}$ & \begin{tabular}{|r|}
707.23 \\
50.86 \\
50.48 \\
40.19 \\
23.30 \\
16.42 \\
21.82 \\
no 21.92 \\
\end{tabular} & \begin{tabular}{|r|}
876.42 \\
73.37 \\
115.94 \\
37.02 \\
29.46 \\
55.44 \\
no rample \\
no sample
\end{tabular} & $\begin{array}{l}571.2 \\
61.32 \\
62.22 \\
34.58 \\
53.13 \\
27.68 \\
25.72 \\
3067\end{array}$ & $\begin{array}{r}547.33 \\
\text { sample } \\
8.06 \\
3469 \\
53.6 \\
24.57 \\
18.3 \\
24.56\end{array}$ & $\begin{array}{c}743.12 \\
\text { no sample } \\
12328 \\
128 \\
\text { no sample } \\
\text { no sample } \\
2353 \\
\text { no sample } \\
\text { no sample }\end{array}$ & $\begin{array}{r}19409 \\
\text { no sample } \\
\text { outher } \\
167.08 \\
\text { outier } \\
48.76 \\
38.29 \\
3053\end{array}$ & 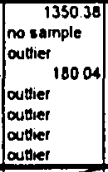 & $\begin{array}{r}1929.12 \\
\text { no } 23 \text { mple } \\
\text { outiler } \\
66.65 \\
50.02 \\
\text { outier } \\
3563 \\
2066 \\
\end{array}$ & \begin{tabular}{|c|}
91.02 \\
no sample \\
130.41 \\
19.23 \\
3586 \\
4281 \\
20.34 \\
2956 \\
\end{tabular} & $\begin{array}{r}470.1 \\
\text { sample } \\
97.57 \\
45.28 \\
29.51 \\
30.05 \\
28.82 \\
17.13\end{array}$ & \begin{tabular}{|r|}
977.715 \\
50.918 \\
86564 \\
73.91833 \\
39.28556 \\
30.267 \\
24.3 \\
24.15657 \\
\end{tabular} & \begin{tabular}{|}
598.407 \\
13.50931 \\
53.53476 \\
65.72101 \\
11.56002 \\
144016 \\
10.80307 \\
6331581 \\
\end{tabular} \\
\hline & & & & & & & & & & & & & & & 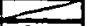 \\
\hline 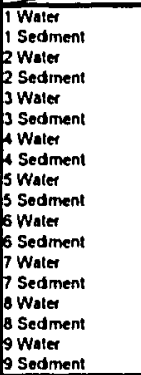 & $\begin{array}{c}\text { no sample } \\
\text { no sample } \\
\text { no sample } \\
\text { no sample } \\
\text { ho sample } \\
\text { ho sample } \\
\text { ho sample } \\
\text { ho sample } \\
\text { ho sample } \\
\text { ho sample } \\
\text { ho sample } \\
\text { ho sample } \\
\text { ho sample } \\
\text { ho sample } \\
\text { ho sample } \\
\text { ho sample } \\
\text { tho sample } \\
\text { ho sample }\end{array}$ & \begin{tabular}{|r|}
22.18 \\
no somple \\
26.45 \\
no sample \\
no sample \\
no sample \\
35.04 \\
no somple \\
35.57 \\
no sample \\
145 \\
no somple \\
25.77 \\
no sumple \\
1441 \\
no semple \\
27.62 \\
no sample
\end{tabular} & $\mid \begin{array}{r}43.21 \\
\text { no inmple } \\
2500 \\
\text { no sample } \\
46.36 \\
\text { no sample } \\
27.43 \\
\text { no sample } \\
2347 \\
\text { no sample } \\
1453 \\
\text { no } 2 \text { ample } \\
21.59 \\
\text { no sample } \\
96.38 \\
\text { no sample } \\
19 \\
\text { no inmple }\end{array}$ & 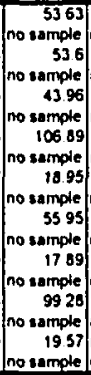 & 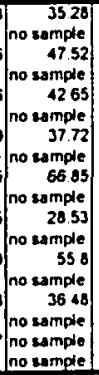 & 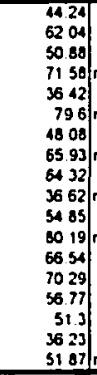 & 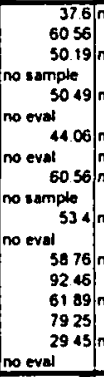 & 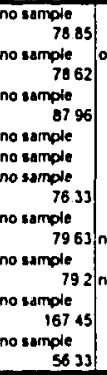 & \begin{tabular}{|c|}
70.74 \\
75.62 \\
outrier \\
64.53 \\
77.37 \\
77.46 \\
67.11 \\
67.13 \\
74.34 \\
63.17 \\
75.89 \\
no eval \\
63.8 \\
no evn \\
73.35 \\
76.53 \\
5936 \\
6015 \\
\end{tabular} & 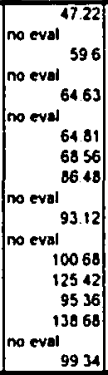 & 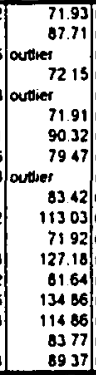 & \begin{tabular}{|l|} 
no sample \\
no sample \\
no sample \\
no sample \\
no sample \\
no sample \\
no sample \\
no sample \\
no sample \\
no sample \\
no sample \\
no sample \\
no sample \\
no ssimple \\
no sample \\
no somple \\
no sample \\
no sample
\end{tabular} & $\begin{array}{l}\text { no sample } \\
\text { no ssmple } \\
\text { no sample } \\
\text { no sample } \\
\text { no sample } \\
\text { no sample } \\
\text { no sample } \\
\text { no sample } \\
\text { no sample } \\
\text { no sample } \\
\text { no wample } \\
\text { no sample } \\
\text { no sample } \\
\text { no sumple } \\
\text { no sample } \\
\text { no somple } \\
\text { no comple } \\
\text { no sample }\end{array}$ & $\begin{array}{r}47.33667 \\
72.956 \\
45.18857 \\
71.72 \\
51.69714 \\
79.2325 \\
58.02889 \\
75.2725 \\
540675 \\
69805 \\
55.91778 \\
7124667 \\
5977889 \\
89802 \\
7764223 \\
104695 \\
3928571 \\
71412 \\
\end{array}$ & $\begin{array}{l}16.17023 \\
11.53621 \\
1281354 \\
5759358 \\
1432590 \\
6659957 \\
2657011 \\
9841397 \\
24.39384 \\
2241864 \\
3396804 \\
4621519 \\
3651068 \\
21.42105 \\
31.4043 \\
4354909 \\
2389938 \\
2143975 \\
\end{array}$ \\
\hline $\begin{array}{l}\text { Water } \\
\text { Sedment } \\
\text { i Water } \\
\text { Sodment } \\
\text { II Woter } \\
\text { II Sedment } \\
\text { v Water } \\
\text { i Water } \\
\text { n Watet } \\
\text { nI Water } \\
\text { nI Sedment } \\
\text { nII Water } \\
\text { nII Sodment } \\
x \text { Water } \\
x \text { Sedment } \\
\end{array}$ & $\begin{array}{c}\text { ho sample } \\
\text { ho sample } \\
\text { ho sample } \\
\text { ho sample } \\
\text { ho sample } \\
\text { ho sample } \\
\text { ho sample } \\
\text { ho sample } \\
\text { ho sample } \\
\text { ho sample } \\
\text { ho sample } \\
\text { ho sample } \\
\text { to sample } \\
\text { ho sample } \\
\text { ho sampie }\end{array}$ & \begin{tabular}{|r}
31.31 \\
no sample \\
2128 \\
no semple \\
no value \\
no sample \\
21.96 \\
no value \\
3557 \\
172 \\
no sample \\
2183 \\
no semple \\
2674 \\
no sample
\end{tabular} & $\mid \begin{array}{cc}27 & 24 \\
\text { no sample } \\
\text { ourtier } \\
\text { no sampic } \\
1981 \\
\text { no inmple } \\
22.76 \\
29.93 \\
32.99 \\
952 \\
\text { no sample } \\
75 \\
\text { no inmple } \\
1273 \\
\text { no sample }\end{array}$ & 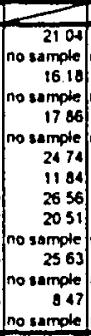 & 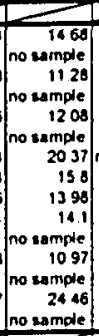 & 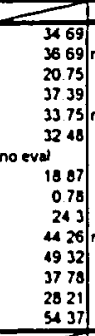 & 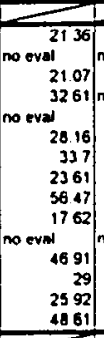 & 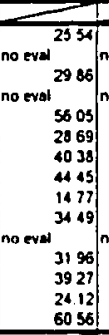 & \begin{tabular}{|c|c|}
5566 \\
no eval \\
4271 \\
51.3 \\
3929 \\
37.11 \\
2786 \\
2682 \\
no eval \\
4561 \\
4633 \\
4327 \\
5605
\end{tabular} & \begin{tabular}{|r|r|}
44.99 \\
no eval \\
2529 \\
8937 \\
27.14 \\
3069 \\
2799 \\
2089 \\
no evat \\
3012 \\
6236 \\
2047 \\
6776
\end{tabular} & 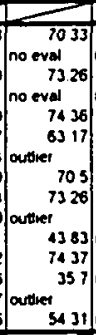 & \begin{tabular}{|c|c|}
5503 \\
no somple \\
48 & 14 \\
3466 \\
49 \\
5645 \\
5271 \\
4290 \\
no 20 mpde \\
51.87 \\
no sample \\
7328 \\
no sample
\end{tabular} & 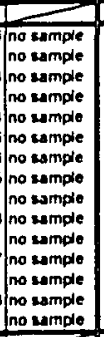 & $\begin{array}{r}37.56818 \\
3669 \\
34936 \\
35 \\
365722 \\
45.83286 \\
31.12667 \\
33925 \\
3299 \\
23643 \\
44045 \\
42.14455 \\
4500333 \\
29567 \\
56991333 \\
\end{array}$ & 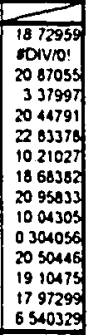 \\
\hline & & & & & & & & & & & & & & & \\
\hline 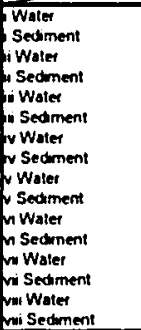 & 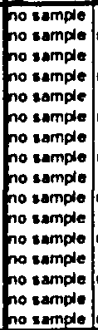 & $\begin{array}{r}1636 \\
\text { no sample } \\
25.53 \\
\text { no sample } \\
2399 \\
\text { no semple } \\
15.13 \\
\text { no semple } \\
1471 \\
\text { no sample } \\
1155 \\
\text { no sample } \\
2707 \\
\text { no sample } \\
12.18 \\
\text { no sumpie }\end{array}$ & $\mid \begin{array}{rr}150 \\
\text { no sample } \\
1543 \\
\text { no sample } \\
1093 \\
\text { no sample } \\
3546 \\
\text { no sample } \\
12.17 \\
\text { no sample } \\
5400 \\
\text { no sample } \\
1307 \\
\text { no sample } \\
2084 \\
\text { no sumple }\end{array}$ & 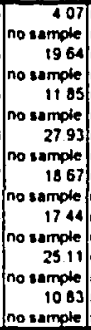 & 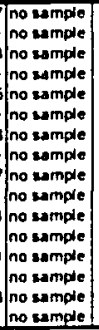 & $\begin{array}{lll}26 & 81 \\
11 & 92 \\
10 & 35 \\
20 & 41 \\
19 & 39 \\
16 & 02 \\
27 & 32 \\
17 & 02 \\
21 & 46 \\
23 & 64 \\
20 & 22 \\
33 & 56 \\
28 & 95 \\
14 & 5 \\
27 & 00 \\
15 & 86\end{array}$ & $\mid$\begin{tabular}{c|c}
13 & 26 \\
no eval \\
33 & 85 \\
22 & 6 \\
40 & 59 \\
20 & 57 \\
26 & 09 \\
no eval & \\
4 & 48 \\
no eval & \\
20 & 27 \\
16 & 75 \\
28 & 77 \\
no eval \\
25 & 31 \\
0 & 13
\end{tabular} & 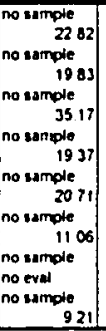 & $\begin{array}{ll}30 & 39 \\
30 & 46 \\
42 & 25 \\
30 & 72 \\
44 & 04 \\
26 & 59 \\
41 & 34 \\
29 & 98 \\
44 & 24 \\
22 & 42 \\
49 & 55 \\
22 & 36 \\
24 & 95 \\
20 & 33 \\
26 & 25 \\
15 & 57\end{array}$ & $\begin{array}{lll}33 & 47 \\
41 & 47 \\
32 & 35 \\
39 & 21 \\
34 & 07 \\
36 & 55 \\
28 & 50 \\
29 & 05 \\
27 & 21 \\
25 & 24 \\
35 & 45 \\
17 & 87 \\
31 & 13 \\
15 & 2 \\
26 & 53 \\
24 & 03 \\
\end{array}$ & 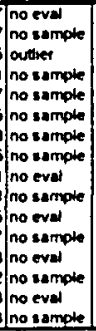 & $\begin{array}{lll}45 & 24 \\
2 & 4 & 08 \\
47 & 58 \\
25 & 7 \\
55 & 83 \\
35 & 03 \\
44 & 42 \\
20 & 26 \\
49 & 9 \\
24 & 50 \\
42 & 03 \\
14 & 53 \\
42 & 38 \\
14 & 03 \\
43 & 52\end{array}$ & 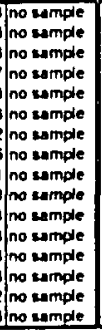 & 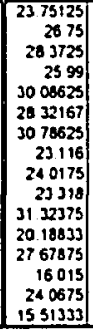 & \begin{tabular}{|c|c|}
366534 \\
9911675 \\
1300545 \\
7558674 \\
161897 \\
8648987 \\
9346547 \\
5922722 \\
1556632 \\
180267 \\
1608479 \\
9744476 \\
8094756 \\
2916556 \\
1016968 \\
6158307 \\
\end{tabular} \\
\hline
\end{tabular}


Table B-16 Sample $B O D_{5}$ Concentrations (2003)

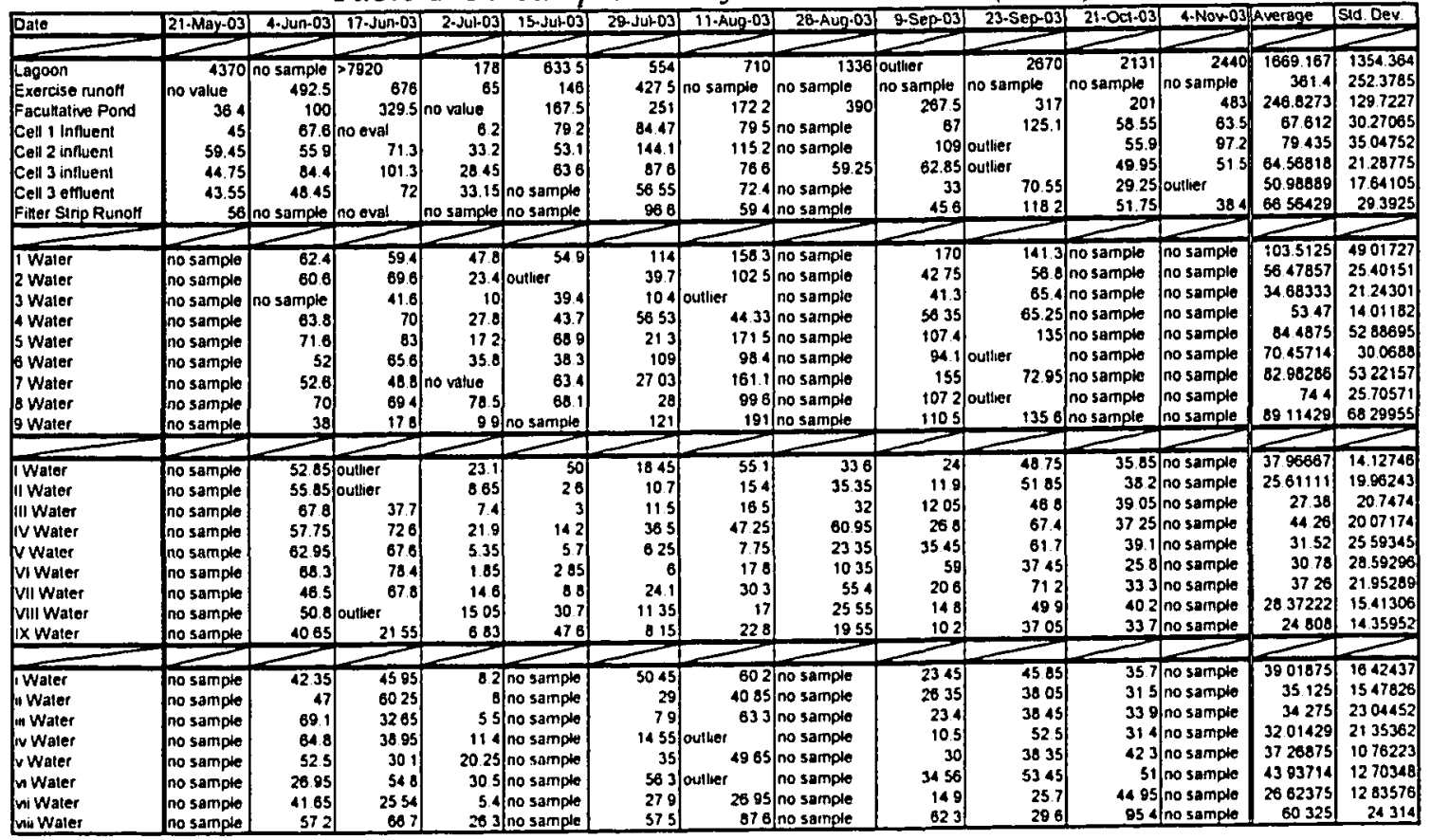

Table B-17 Sample $B O D_{5}$ Concentrations (2004)

\begin{tabular}{|c|c|c|c|c|c|c|c|c|}
\hline Dato & 25-MaY-04 & 9.Jun-041 & 23-Jun-04 & 6-Jut-04 & $20-\sqrt{u} t-04$ & 4.Aug-04 & Average & Sid. Dev \\
\hline & & & & $=$ & & & & 7 \\
\hline $\begin{array}{l}\text { Lagoon } \\
\text { Exerose nunof } \\
\text { Facultativo Pond } \\
\text { Cell } 1 \text { Influent } \\
\text { Cell } 2 \text { infuent } \\
\text { Cell } 3 \text { influent } \\
\text { Call } 3 \text { effuent } \\
\text { Filter Stro Runolf }\end{array}$ & $\begin{array}{l}\text { no oval } \\
\text { no eval } \\
\text { no oval } \\
\text { no oval } \\
\text { no oval } \\
\text { no eval } \\
\text { no oval } \\
\text { no oval }\end{array}$ & $\begin{array}{r}6705 \\
238 \\
386 \\
508 \\
4875 \\
17 \\
25 \\
108\end{array}$ & $\begin{array}{r}815 \\
285 \\
426 \\
658 \\
595 \\
10.5 \\
589 \\
189\end{array}$ & $\begin{array}{r}1086 \\
1307 \\
1048 \\
194 \\
3755 \\
471\end{array}$ & $\begin{array}{r}1010 \\
97.5 \\
859 \\
260 \\
539 \\
55 \\
41.4 \\
323 \\
\end{array}$ & $\begin{array}{r}1090 \\
568 \\
10047 \\
176 \\
5405 \\
1259 \\
892\end{array}$ & \begin{tabular}{|r|}
9396 \\
11876 \\
74474 \\
14932 \\
5075 \\
511 \\
53625 \\
20666667
\end{tabular} & \begin{tabular}{|r|}
181.00256 \\
101.34931 \\
31.736838 \\
88938138 \\
83008283 \\
45927715 \\
27460563 \\
1085833 \\
\end{tabular} \\
\hline & 7 & & & & & & $\longrightarrow$ & $\longrightarrow$ \\
\hline - & no sample & 378 & $59 \quad 15$ & $d y$ & tracer & 688 & 5525 & 15863716 \\
\hline 2. & no samplo & 34 & 45.1 & $d y$ & tracer & 5725 & 45.45 & 11628951 \\
\hline 3. & no sample & $d y$ & dry & $d y$ & tracer & 66.6 & 666 & EDIVN" \\
\hline 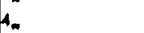 & no sample & dry & 5655 & $d y$ & tracor & tracor & 5655 & DIVIO! \\
\hline 5 & no samplo & 36 & 38 15 & 53 & racer & tracer & 42.383333 & 9.2569343 \\
\hline 6 & no sample & 562 & 54.5 & 332 & tracer & tracer & 47966667 & 12816526 \\
\hline $7_{n}^{n}$ & no samplo & 676 & 52.55 & 3955 & tracer & tracer & 53233333 & 1403748 \\
\hline 8. & no samplo & 608 & 58 & 2985 & tracer & tracer & 4955 & 17118046 \\
\hline$g_{m}$ & no sample & 56 & 423 & 4645 & tracer & Iracer & 4825 & 70251335 \\
\hline & & & & & & & & \\
\hline 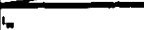 & no samplo & 121 & tracor & 171 & 3055 & 2505 & 21225 & 82410052 \\
\hline m & no sample & 171 & tracer & 2455 & 3135 & 35 & & 78937739 \\
\hline س. & no samplo & 33 & tracer & 331 & 27.05 & 227 & 289625 & 50430439 \\
\hline$y$ & no sample & 125 & tracer & 28 & 339 & 234 & $24 \quad 45$ & 9.0518875 \\
\hline ra & no sample & 3335 & tracor & 159 & dy & 2365 & 243 & 87431402 \\
\hline$n_{m}$ & samplo & 137 & tracer & 193 & 295 & 30 & 23.125 & 7986812 \\
\hline rii & sample & 1665 & tracor & 133 & 247 & 12.1 & 166875 & 56780929 \\
\hline then & no sample & dry & tracer & 197 & 253 & 238 & 22.933333 & 2.8988503 \\
\hline
\end{tabular}


Table B-18 Water Balance: June 2003

\begin{tabular}{|c|c|c|}
\hline 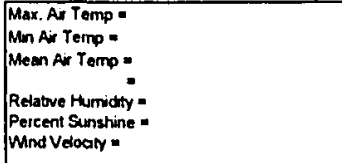 & $\begin{array}{r}25^{\circ} \mathrm{C} \\
85^{\circ} \mathrm{C} \\
17.7^{\circ} \mathrm{C} \\
29085 \mathrm{~K} \\
71.5 \% \\
60 \% \\
0.35 \mathrm{~m} / \mathrm{s}\end{array}$ & \\
\hline \multicolumn{3}{|c|}{ Vegetaled Surtace Wedand - Penman Equation for Evapotranspiration } \\
\hline $\begin{array}{l}\text { Sat, Water Pressure (Mean Temo) - } \\
\text { Actual Water Pressure = }\end{array}$ & $\begin{array}{l}2019781 \mathrm{kPa} \\
1.444129 \mathrm{kPa}\end{array}$ & \\
\hline $\begin{array}{l}\text { Dew Pont Ternp = } \\
\text { Sat. Water Pressure (Dew Point)= } \\
\text { Sat. Water Pressure (Max Temp) = } \\
\text { Sat. Water Pretsure (Min Temp) = } \\
\text { Avg Sat Water Pressive = }\end{array}$ & $\begin{array}{c}24^{\circ} \mathrm{C} \\
0.727341 \mathrm{kPa} \\
3.169781 \mathrm{kPa} \\
1.184529 \mathrm{kPa} \\
2.176655 \mathrm{kPa}\end{array}$ & \\
\hline $\begin{array}{l}\text { Extratertestral Radiation - } \\
\text { Solver Rediabon = }\end{array}$ & $\begin{array}{r}35 \mathrm{ML} / \mathrm{m}^{2} / \mathrm{d} \\
1925 \mathrm{MJim} \mathrm{m}^{2} / \mathrm{d}\end{array}$ & Figule 9-3 kadec \& Krught. 187 \\
\hline $\begin{array}{l}\text { Net Long Wove Back Radiation - } \\
\text { Net Incommg Radiabon - } \\
\text { Penmen Factor - }\end{array}$ & $\begin{array}{l}4972027 \mathrm{ML} / \mathrm{m}^{2} / \mathrm{d} \\
9849673 \mathrm{M} / \mathrm{m}^{2} / \mathrm{d} \\
0638\end{array}$ & \\
\hline 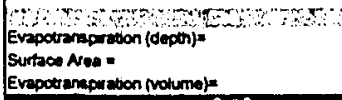 & $\begin{array}{l}4.070609 \mathrm{~mm} / \mathrm{d} \\
1353 \mathrm{~m}^{2} \\
5.507534 \mathrm{~m}^{1 / \mathrm{d}}\end{array}$ & 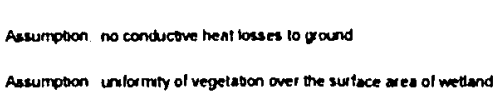 \\
\hline 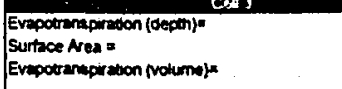 & $\begin{array}{l}4.070309 \mathrm{mmnt} \\
1009 \mathrm{~m}^{2} \\
4.4322093 \mathrm{~m}^{1 / 1 \mathrm{~d}}\end{array}$ & 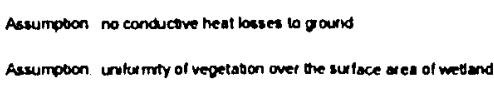 \\
\hline \multicolumn{3}{|c|}{ Non.Vepetsted Surface Wettend - Hamon Equation for Evaporation } \\
\hline 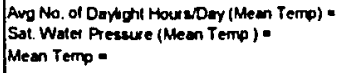 & $\begin{array}{r}12 \mathrm{hu} / \mathrm{d} \\
2019781 \mathrm{kPs} \\
17.7^{\circ \mathrm{C} C}\end{array}$ & \\
\hline 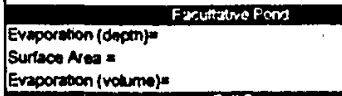 & $\begin{array}{l}2.009607 \mathrm{~mm} / \mathrm{m} \\
1914 \mathrm{~m}^{2} \\
4.010649 \mathrm{~m}^{2 / 4}\end{array}$ & \\
\hline 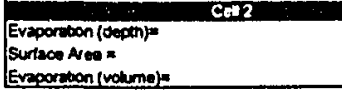 & $\begin{array}{l}2.009007 \mathrm{mmnt} \\
2178 \mathrm{~m}^{2} \\
4.572945 \mathrm{~m}^{3} / \mathrm{d}\end{array}$ & \\
\hline
\end{tabular}

Table B-19 Water Balance: July 2003

\begin{tabular}{|c|c|c|}
\hline Mar Ao Temp= & $286^{\circ} \mathrm{C}$ & \\
\hline $\operatorname{Min} A=\operatorname{Temp}=$ & $12.8^{\circ} \mathrm{C}$ & \\
\hline 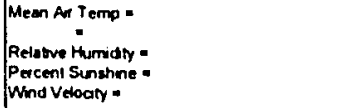 & $\begin{array}{r}196^{\circ} \mathrm{C} \\
20275 \mathrm{~K} \\
685 \% \\
65 \% \\
035 \mathrm{~min}\end{array}$ & \\
\hline \multicolumn{3}{|c|}{ Veqeented Surface Wotlend . Penmun Equetion for Evapolimspination } \\
\hline $\begin{array}{l}\text { Sat. Water Preasure (Mean Temp) = } \\
\text { Aculd Water Pressure - }\end{array}$ & $\begin{array}{l}2.275666 \mathrm{kPn} \\
1.513451 \mathrm{kPa}\end{array}$ & \\
\hline 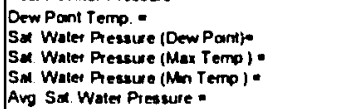 & $\begin{array}{c}241^{\circ} \mathrm{C} \\
0.727341 \mathrm{kPa} \\
3467206 \times P_{a} \\
1454534 \mathrm{KPa} \\
2470915 \text { \&Pa }\end{array}$ & \\
\hline Extsterreatral Radation . & 35 Muminid & Froure 9.3 Kadece \& Krogh, 107 \\
\hline Solur Restasion. & $20.125 \mathrm{Nu} / \mathrm{m}^{3} / \mathrm{d}$ & \\
\hline Nel Long Wave Back Radiaton. & $5462925 \mathrm{MH} / \mathrm{m}^{2} / \mathrm{d}$ & \\
\hline $\begin{array}{l}\text { Net incoming Ravabon - } \\
\text { Penmen Factor - }\end{array}$ & $\begin{array}{l}1003322 \mathrm{~m} / \mathrm{m} / \mathrm{m} / \mathrm{d} \\
0636\end{array}$ & \\
\hline \multicolumn{3}{|c|}{ Evapotranapration (depth)= } \\
\hline $\begin{array}{l}\text { Evapotranapration }(\text { depth })= \\
\text { Surfact Aies = }\end{array}$ & $4423136 \mathrm{~mm}^{2} \mathrm{~d}$ & Assumption no conductove heat losses to ground \\
\hline 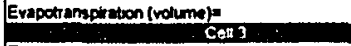 & $5.980643 m^{3} / d$ & Acsumpotion assurning unitarity over the sinface wea of the welland \\
\hline 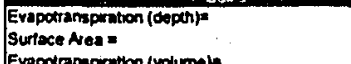 & 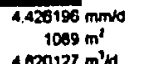 & Asaumption no contuctove the bet losses to ground \\
\hline Evepotranapration (volume) & $4.020127 \mathrm{~m}^{1} / \mathrm{d}$ & Aesumption assumno untormity over the surface ares of the wetand \\
\hline \multicolumn{3}{|c|}{ Non-Vogetated Surtace Wotland - Hamon Equallon for Evaporintion } \\
\hline 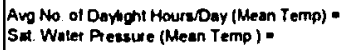 & $\begin{aligned} 13 \mathrm{~m} / \mathrm{i} \\
2.275868 \mathrm{kPa}\end{aligned}$ & \\
\hline Mean Temp = & $190^{\circ} \mathrm{C}$ & \\
\hline Fstilkstue Pand & & \\
\hline $\begin{array}{l}\text { Evaporation (oeptin) } \\
\text { Surfece Nea : } \\
\text { Evaporation (volumne) }\end{array}$ & $\begin{array}{l}2.758551 \mathrm{~mm} / \mathrm{d} \\
1914 \mathrm{~m}^{2} \\
5279873 \mathrm{~m}^{2 / \mathrm{d}}\end{array}$ & \\
\hline $\begin{array}{l}\text { Evaporation (depth) } \\
\text { Surtace Nres: } \\
\text { Evaporation (volume). }\end{array}$ & $\begin{array}{c}2730554 \mathrm{~mm} / \mathrm{d} \\
2174 \mathrm{~m}^{2} \\
6000131 \mathrm{~m}^{2} / 0\end{array}$ & \\
\hline
\end{tabular}


Table B-20 Water Balance: August 2003

\begin{tabular}{|c|c|c|}
\hline 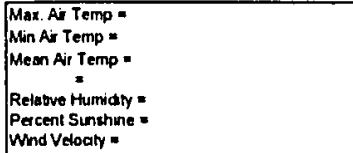 & $\begin{array}{r}26.7^{\circ} \mathrm{C} \\
13.3^{\circ} \mathrm{C} \\
199^{\circ} \mathrm{C} \\
293.05 \mathrm{~K} \\
68 \% \\
65 \% \\
0.35 \mathrm{~m} / \mathrm{s}\end{array}$ & \\
\hline \multicolumn{3}{|c|}{ Vogetstod Surfoce Wottond - Penman Equation for Evapoltanspiration } \\
\hline $\begin{array}{l}\text { Sat. Water Pressure (Mean Temp.) - } \\
\text { Actud Water Pressure = }\end{array}$ & $\begin{array}{l}2.318844 \mathrm{kPa} \\
1.530437 \mathrm{kP}\end{array}$ & \\
\hline 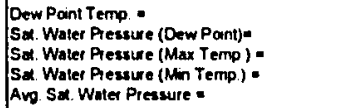 & $\begin{array}{l}24^{\circ} \mathrm{C} \\
0.727341 \mathrm{kPa} \\
3.508115 \mathrm{kPa} \\
1.52027 \mathrm{kPa} \\
2515371 \mathrm{kPa}\end{array}$ & \\
\hline Exrslenestial Rodintion - & $35 \mathrm{~mJ} / \mathrm{m}^{\prime} / \mathrm{d}$ & Figure 9-3 Kadtec \& Kright. 187 \\
\hline $\begin{array}{l}\text { Solul Radiaton n } \\
\text { Net Long Wave Back Radiation - }\end{array}$ & $\begin{array}{r}20.125 \mathrm{MJ} / \mathrm{m}^{2} / \mathrm{d} \\
5.485353 \mathrm{MJ} / \mathrm{m}^{2} / \mathrm{d}\end{array}$ & \\
\hline $\begin{array}{l}\text { Net incoming Redabon } \\
\text { Penman Factor - }\end{array}$ & $\begin{array}{l}10.0109 \mathrm{~mJ} / \mathrm{m}^{2} / 0 \\
0636\end{array}$ & \\
\hline 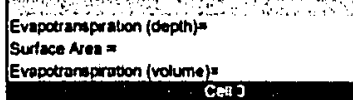 & $\begin{array}{l}4.466909 \mathrm{~mm} / \mathrm{d} \\
1353 \mathrm{~m}^{2} \\
6.043726 \mathrm{~m}^{2} / \mathrm{s}\end{array}$ & $\begin{array}{l}\text { Assumption: no conductove hest losses to ground } \\
\text { Assumpoon sssurnang unitormity over the surface wea of the wetind }\end{array}$ \\
\hline 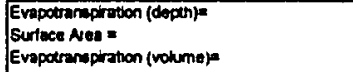 & $\begin{array}{l}4.466009 \mathrm{~mm} / \mathrm{d} \\
1009 \mathrm{~m}^{2} \\
486464 \mathrm{~m}^{2} \mathrm{do}\end{array}$ & 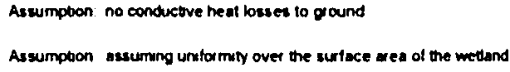 \\
\hline \multicolumn{3}{|c|}{ Non.Vegatated Surface Wotland - Harmon Equation for Evapor ation } \\
\hline 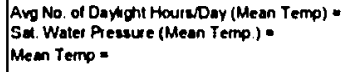 & $\begin{array}{l}12 \mathrm{hild} \\
2.318844 \mathrm{kPa} \\
190^{\circ} \mathrm{C}\end{array}$ & \\
\hline 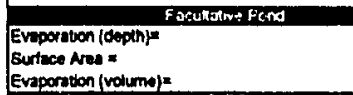 & $\begin{array}{l}239242 \mathrm{~mm} / \mathrm{d} \\
1914 \mathrm{~m}^{2} \\
4579002 \mathrm{~m}^{2} \mathrm{ds}\end{array}$ & \\
\hline $\begin{array}{l}\text { Evaporition (dexth) } \\
\text { Surtace Aven I } \\
\text { Eveporition frotume }\end{array}$ & $\begin{array}{c}230242 \mathrm{mmnts} \\
2176 \mathrm{~m}^{2} \\
5210091 \mathrm{~m}^{2} \mathrm{~s}\end{array}$ & \\
\hline
\end{tabular}

Table B-2I Water Balance: September 2003

\begin{tabular}{|c|c|c|}
\hline 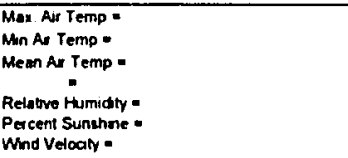 & $\begin{array}{r}228^{\circ} \mathrm{C} \\
85^{\circ} \mathrm{C} \\
157^{\circ \mathrm{C}} \\
266.65 \mathrm{~K} \\
627 \mathrm{~K} \\
60 \% \\
18 \mathrm{~m} / \mathrm{s}\end{array}$ & \\
\hline \multicolumn{3}{|c|}{ Vegetalied Surfuce Wettand - Penman Equation for Evopotrenspiration } \\
\hline $\begin{array}{l}\text { Sat Water Pressure (Mean Temp) ". } \\
\text { Actwal Woter Preasure - }\end{array}$ & $\begin{array}{l}1.77823 \mathrm{kPa} \\
1.11495 \mathrm{kPa}\end{array}$ & \\
\hline 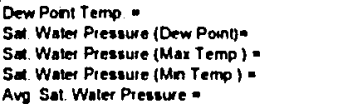 & $\begin{array}{l}24^{\circ} \mathrm{C} \\
0.77341 \mathrm{kPa} \\
2.77308 \mathrm{KPa} \\
1.10754 \mathrm{KPa} \\
1.24031 \mathrm{KPa}\end{array}$ & \\
\hline Exvatarestris Radintion . & $35 \mathrm{~mJ} / \mathrm{m}^{2} / \mathrm{d}$ & Figure 93 Kadec 8 Knoth. 187 \\
\hline Sodur Radation - & $1925 \mathrm{MJ} / \mathrm{m}^{2} / \mathrm{d}$ & \\
\hline $\begin{array}{l}\text { Net Long Wave Bach Radiation : } \\
\text { Net Incoming Radabon - } \\
\text { Penman Factor " }\end{array}$ & $\begin{array}{l}\text { 4. } 837451 \mathrm{M} / \mathrm{mi} / \mathrm{d} \\
0935049 \mathrm{M} \mathrm{d} / \mathrm{m}^{2} / \mathrm{d} \\
0633\end{array}$ & \\
\hline 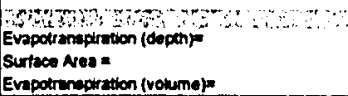 & $\begin{array}{l}532316 \mathrm{~mm} / \mathrm{d} \\
1353 \mathrm{~m}^{2} \\
7.473241 \mathrm{~m}^{2} / \mathrm{d}\end{array}$ & $\begin{array}{l}\text { Assumption no conductive hest losses to ground } \\
\text { Assumpion nstumng unitormity over the surtace sied of the wettand }\end{array}$ \\
\hline 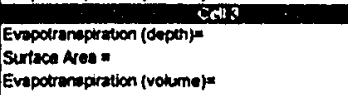 & $\begin{array}{l}5.52346 \mathrm{~mm} / \mathrm{d} \\
1000 \mathrm{~m}^{2} \\
6015048 \mathrm{~m}^{2} / \mathrm{d}\end{array}$ & 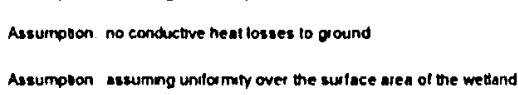 \\
\hline \multicolumn{3}{|c|}{ Non.Vegotated Surface Wetrend - Hamon Equation for Evaporation } \\
\hline 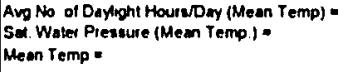 & $\begin{array}{l}11 \mathrm{hid} \\
1.77823^{\mathrm{kPa}} \\
157^{\circ} \mathrm{C}\end{array}$ & \\
\hline 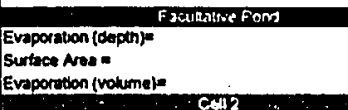 & $\begin{array}{c}1.56403 \mathrm{~mm} / \mathrm{d} \\
1914 \mathrm{~m}^{2} \\
2903553 \mathrm{~m}^{2} / \mathrm{d}\end{array}$ & \\
\hline $\begin{array}{l}\text { Eveporation (depth) } \\
\text { Surface Aves = } \\
\text { Evaporation (volumper }\end{array}$ & $\begin{array}{c}1.56403 \mathrm{~mm} / \mathrm{d} \\
2170 \mathrm{~m}^{\prime} \\
3400458 \mathrm{~m}^{3} / \mathrm{A}\end{array}$ & \\
\hline
\end{tabular}


Table B-22 Water Balance: October 2003

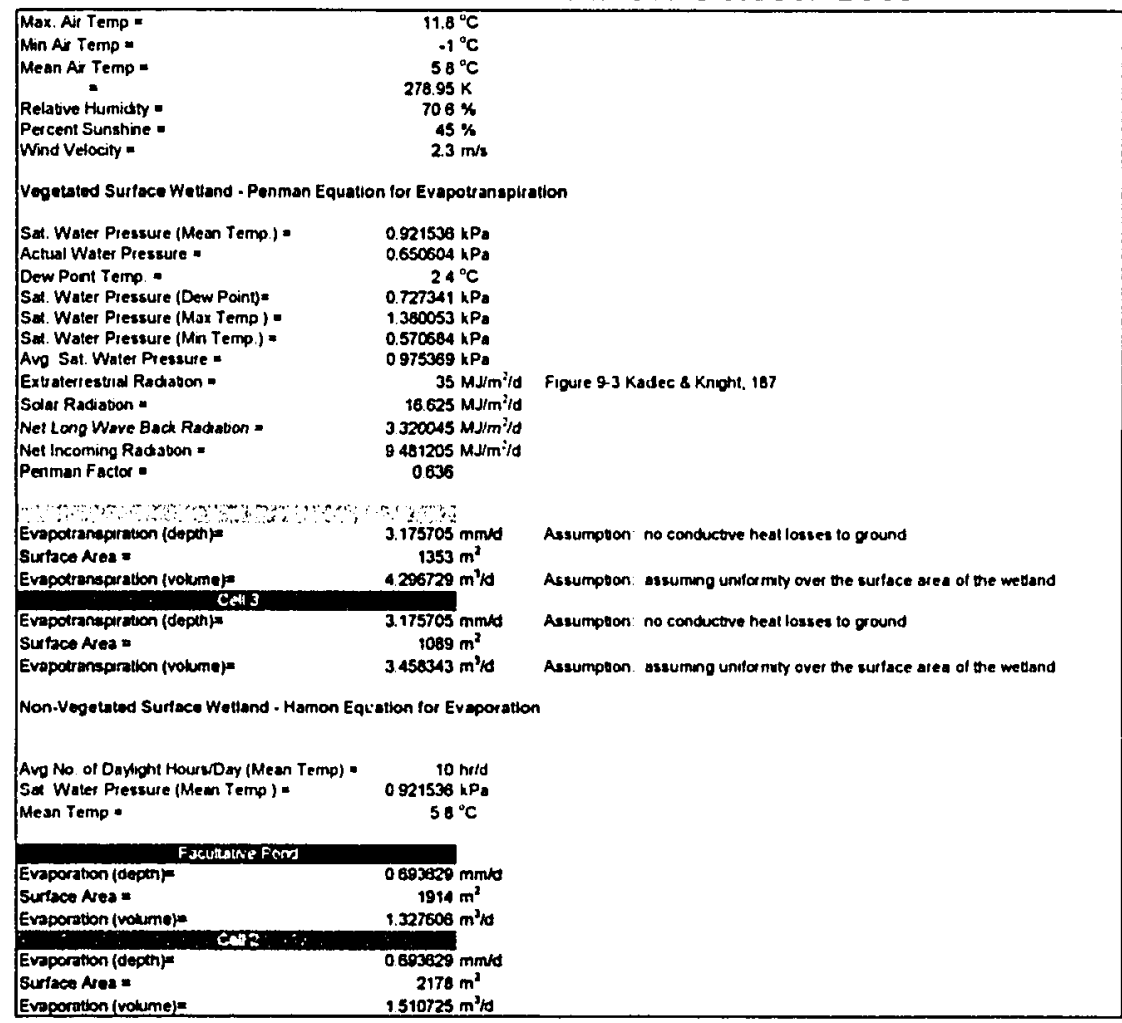




\section{APPENDIX C \\ TRACER CONCENTRAION DATA}

134

Reproduced with permission of the copyright owner. Further reproduction prohibited without permission. 
Table C-1 Tracer Concentration Data

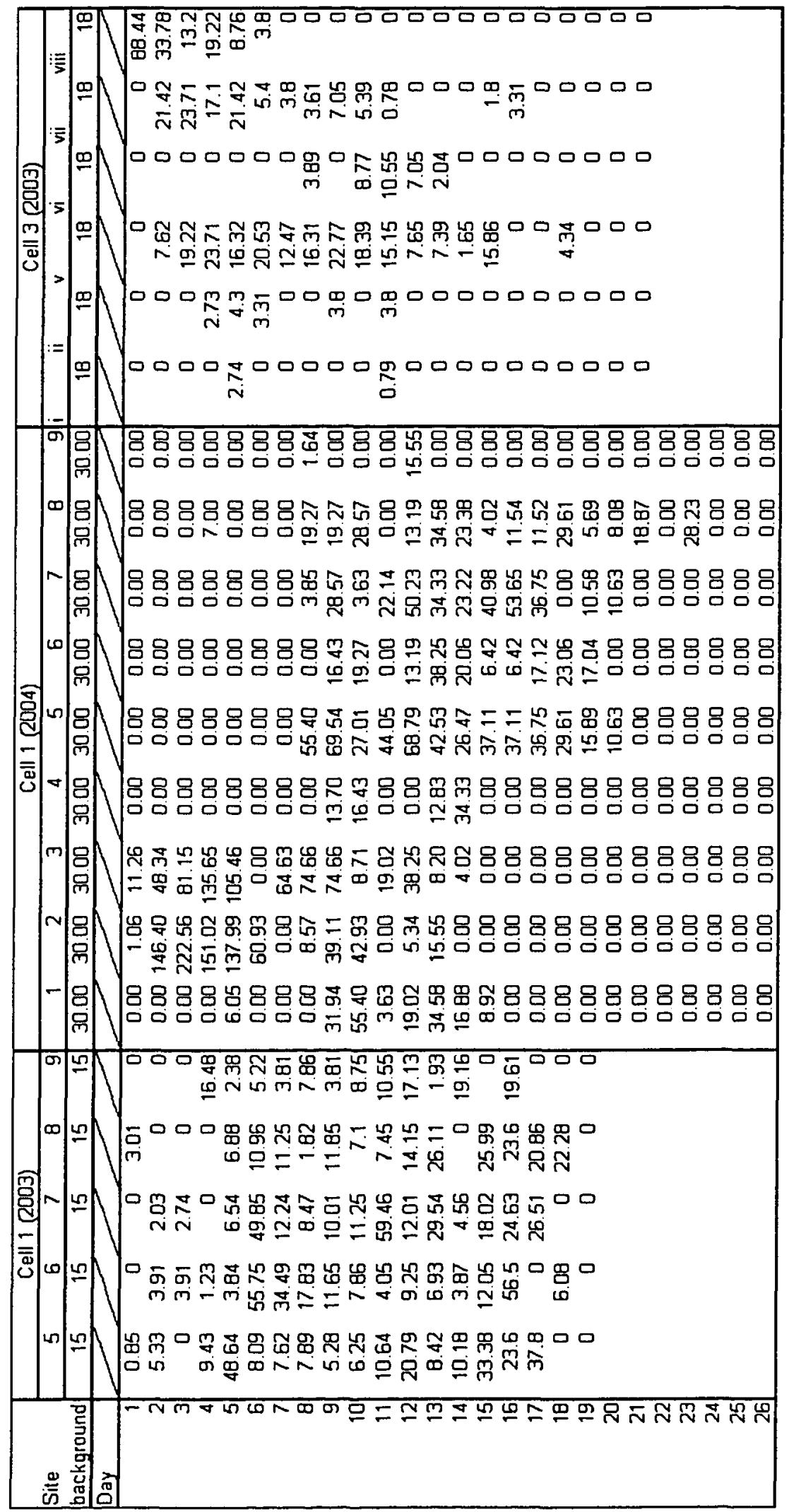




\section{APPENDIX D \\ MODEL CALCULATIONS AND RESIDENCE TIME DISTRIBUTIONS}


Table D-1 Model Calculations (2003)

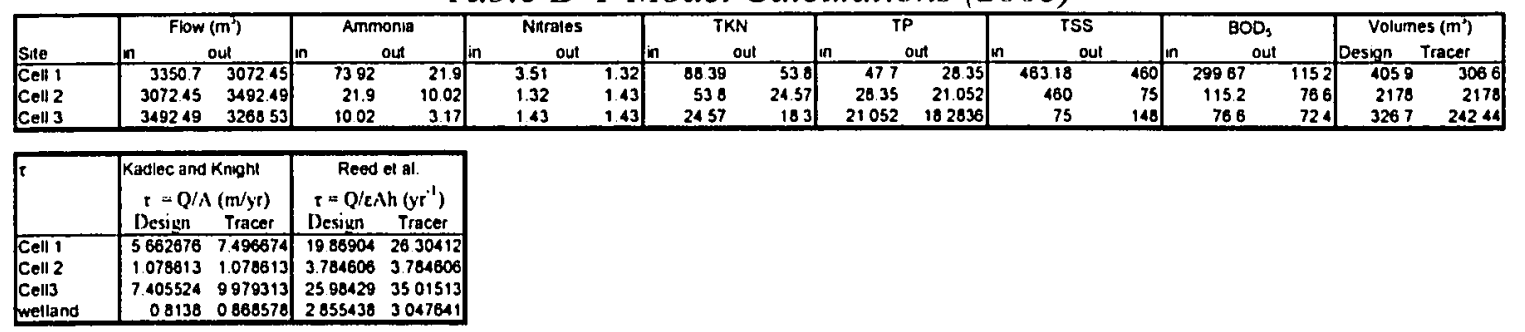

\begin{tabular}{|c|c|c|c|c|c|c|c|c|c|c|c|c|c|}
\hline \multirow{3}{*}{$\begin{array}{l}\text { Background } \\
\text { calculations }\end{array}$} & \multirow{6}{*}{ 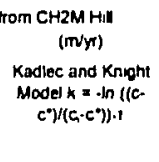 } & & \multirow{2}{*}{\multicolumn{2}{|c|}{0}} & \multicolumn{2}{|r|}{10} & & \multicolumn{2}{|r|}{20} & \\
\hline & & & & & & & & & & & & & \\
\hline & & & & Design & & Desi & & & & & & & \\
\hline cell 1 & & 7.486289 & & 5538008 & & & & & 1894 & & & & \\
\hline 112 & & 1068257 & & .0086335 & .008 & 1.187196 & & 034978 & & 2006965 & 2.08 & 0.48 & \\
\hline $\begin{array}{l}\text { cell } 3 \\
\text { wetland }\end{array}$ & & $\begin{array}{l}27.55388 \\
4910069\end{array}$ & & "NUM! ${ }^{0}$ & NNUM! ${ }^{\circ}$ & \begin{tabular}{|l|l}
4 & 167156 \\
1399228
\end{tabular} & & & & & & & \\
\hline assurnedy & & & 10 & & & & & & 6 & & 21 & & 22 \\
\hline tren & $\begin{array}{l}\text { cell } 1 \\
\text { cell } 3\end{array}$ & $\begin{array}{r}25.11731 \\
.1755380 \\
\end{array}$ & $\begin{array}{r}08 B 4695 \\
.2713023\end{array}$ & $\begin{array}{l}\text { Nolvio! } \\
\text { wolvro! }\end{array}$ & $\begin{array}{l}\text { DDIVR! } \\
\text { molvo! }\end{array}$ & $\begin{array}{r}7845692 \\
702346\end{array}$ & $\begin{array}{l}68.03191 \\
5988964\end{array}$ & $\begin{array}{r}81.02451 \\
854854\end{array}$ & $\begin{array}{r}48.40133 \\
804139\end{array}$ & \begin{tabular}{|l|}
99.80582 \\
1265494
\end{tabular} & $\begin{array}{l}9974862 \\
1357766\end{array}$ & $\begin{array}{l}7423871 \\
9787331\end{array}$ & $\begin{array}{r}6589263 \\
9713417\end{array}$ \\
\hline
\end{tabular}

\begin{tabular}{|c|c|c|c|c|c|c|c|c|c|c|c|c|}
\hline \multirow[t]{2}{*}{ calculations } & \multirow{4}{*}{$\begin{array}{c}\left(y r^{\prime}\right) \\
\text { Reed el al Model k - } \\
\text { In(UC) }=1\end{array}$} & & \multicolumn{2}{|r|}{ h } & \multicolumn{2}{|r|}{ k } & \multicolumn{2}{|r|}{ k } & \multicolumn{2}{|r|}{$k$} & $k$ \\
\hline & & Design & Tracer & Design & Tracer & Design & Iracer & Design & Iracer & Design & Tracef & Tracer \\
\hline $\begin{array}{l}\text { cell 1 } \\
\text { cell 2 } \\
\text { cell 3 } \\
\text { wetland }\end{array}$ & & $\begin{array}{l}2417062 \\
2959197 \\
2990406 \\
8992494\end{array}$ & $\begin{array}{l}3109088 \\
2959197 \\
4029722 \\
9597789\end{array}$ & $\begin{array}{r}r 943161 \\
.030293 \\
0 \\
2564017 \\
\end{array}$ & $\begin{array}{r}2572501 \\
.030293 \\
0 \\
2736604\end{array}$ & $\begin{array}{l}9864687 \\
2968175 \\
7655626 \\
4496909 \\
\end{array}$ & $\begin{array}{l}1305961 \\
2966175 \\
1031634 \\
1709601 \\
\end{array}$ & \begin{tabular}{|l}
2846315 \\
0321020 \\
1044113 \\
2738157 \\
\end{tabular} & $\begin{array}{r}3900552 \\
0321029 \\
1406994 \\
2922465\end{array}$ & $\begin{array}{r}0136303 \\
6884268 \\
-1766215 \\
3257779 \\
\end{array}$ & 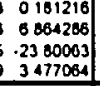 & \begin{tabular}{|lll}
1899504 & 2514706 \\
154398 & 1584394 \\
1465275 & 1974531 \\
105008 & 1329099 \\
10508
\end{tabular} \\
\hline assumect values & & & & & & \multicolumn{2}{|c|}{80} & \multicolumn{2}{|c|}{998} & & & 248 \\
\hline Percenl diffe & $\begin{array}{l}\text { cell } 1 \\
\text { cell } 3\end{array}$ & $\begin{array}{l}\text { "DIVIo! } \\
\text { moIvio! }\end{array}$ & $\begin{array}{l}\text { EDIVIO! } \\
\text { nOIVOI }\end{array}$ & $\begin{array}{l}\text { Divilo! } \\
\text { DDivio! }\end{array}$ & $\begin{array}{l}\text { MOIVR! } \\
\text { molvio! }\end{array}$ & $\begin{array}{l}8766914 \\
9043047\end{array}$ & $\begin{array}{r}8367549 \\
87.10450\end{array}$ & \begin{tabular}{|l|}
7041852 \\
8951694
\end{tabular} & $\begin{array}{l}6083783 \\
8587355\end{array}$ & $\begin{array}{l}\text { molv/0! } \\
\text { molvio! }\end{array}$ & 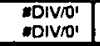 & $\begin{array}{ll}9234071 & 8986006 \\
9940910 & 9920382\end{array}$ \\
\hline
\end{tabular}

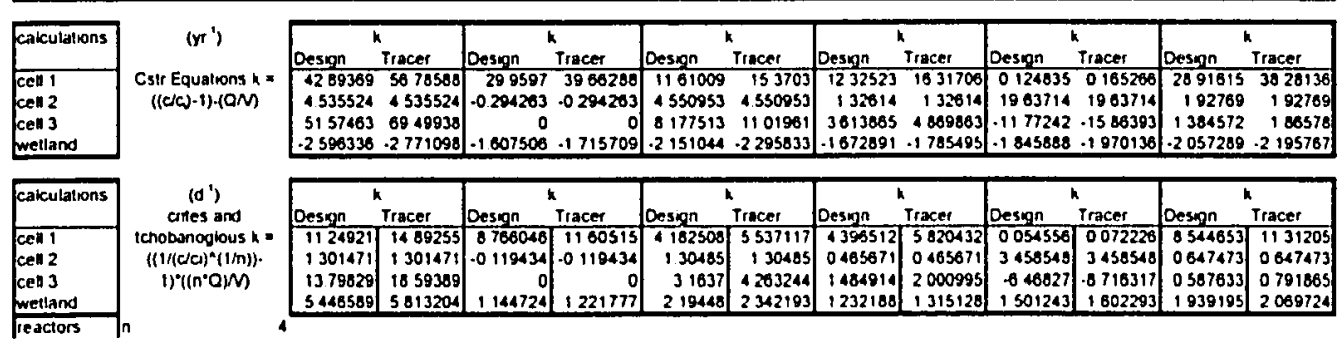


Table D-2 Model Calculations (2004)

\begin{tabular}{|c|c|c|c|c|c|c|c|c|c|c|c|c|c|c|c|c|}
\hline \multirow{3}{*}{$\frac{\text { Site }}{\text { Ceft } 1}$} & \multicolumn{2}{|c|}{ Flow $\left(m^{3}\right)$} & \multicolumn{2}{|c|}{ Ammonia } & \multicolumn{2}{|c|}{ Nitralos } & \multicolumn{2}{|c|}{ TKN } & \multicolumn{2}{|c|}{$T P$} & \multicolumn{2}{|c|}{ ISS } & \multicolumn{2}{|c|}{$B O D}$, & \multicolumn{2}{|c|}{ Volumes $\left(m^{2}\right)$} \\
\hline & in & ut & in & out & in & out & in & & in & out & in & out & 0 & & Design & Tracer \\
\hline & 3350.7 & 3072.45 & 13.3555 & 10.4206 & 1.025167 & 1.074833 & 4826 & $\$ 1.74$ & 18.741 & 11.38217 & 275.439 & 46.152 & 149.32 & 50.75 & 405.9 & 271.7 \\
\hline $\begin{array}{l}\text { Cell } 2 \\
\text { Cett } 3\end{array}$ & $\begin{array}{l}3072.45 \\
349249\end{array}$ & $\begin{array}{l}3492.49 \\
3268.53\end{array}$ & $\begin{array}{r}10.4206 \\
7.1464\end{array}$ & $\begin{array}{r}7.1464 \\
2.10775\end{array}$ & $\begin{array}{l}1.074833 \\
1069667\end{array}$ & $\begin{array}{r}1069687 \\
1.126\end{array} \mid$ & $\begin{array}{r}41.74 \\
21.053\end{array}$ & $\begin{array}{l}21.053 \\
28.277\end{array}$ & $\begin{array}{r}11.38217 \\
11.4315\end{array}$ & $\begin{array}{l}11.4315 \\
110240\end{array}$ & $\begin{array}{r}46.152 \\
442.9583\end{array}$ & $\begin{array}{r}112.9583 \\
766886\end{array}$ & $\begin{array}{r}50.75 \\
51 .\end{array}$ & $\begin{array}{r}51.1 \\
53625\end{array}$ & $\begin{array}{l}2178 \\
3287\end{array}$ & $\begin{array}{r}2178 \\
24244\end{array}$ \\
\hline
\end{tabular}

\begin{tabular}{|c|c|c|c|c|}
\hline \multirow[t]{2}{*}{ 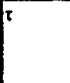 } & \multicolumn{2}{|c|}{$\begin{array}{r}\text { Kadlec and Kright } \\
\tau=Q / \mathrm{A}(\mathrm{m} / \mathrm{yr})\end{array}$} & \multicolumn{2}{|c|}{$\begin{array}{c}\text { Reed el al } \\
\tau=\text { Q/eAh }\left(y r^{\prime}\right)\end{array}$} \\
\hline & Design & Tracer & Design & Tracer \\
\hline $\begin{array}{l}\text { Cell 1 } \\
\text { Cell } 2\end{array}$ & $\begin{array}{l}5662876 \\
1.078613\end{array}$ & $\begin{array}{l}8.459625 \\
1.078613\end{array}$ & $\begin{array}{l}19.86904 \\
3.784606\end{array}$ & $\begin{array}{r}296029 \\
3.784606\end{array}$ \\
\hline $\begin{array}{l}\text { Cell3 } \\
\text { weltand }\end{array}$ & $\begin{array}{r}7.405524 \\
08138\end{array}$ & $\begin{array}{l}9.979313 \\
0879838\end{array}$ & $\begin{array}{l}25.98429 \\
2855438\end{array}$ & $\begin{array}{r}35.01513 \\
308715\end{array}$ \\
\hline
\end{tabular}

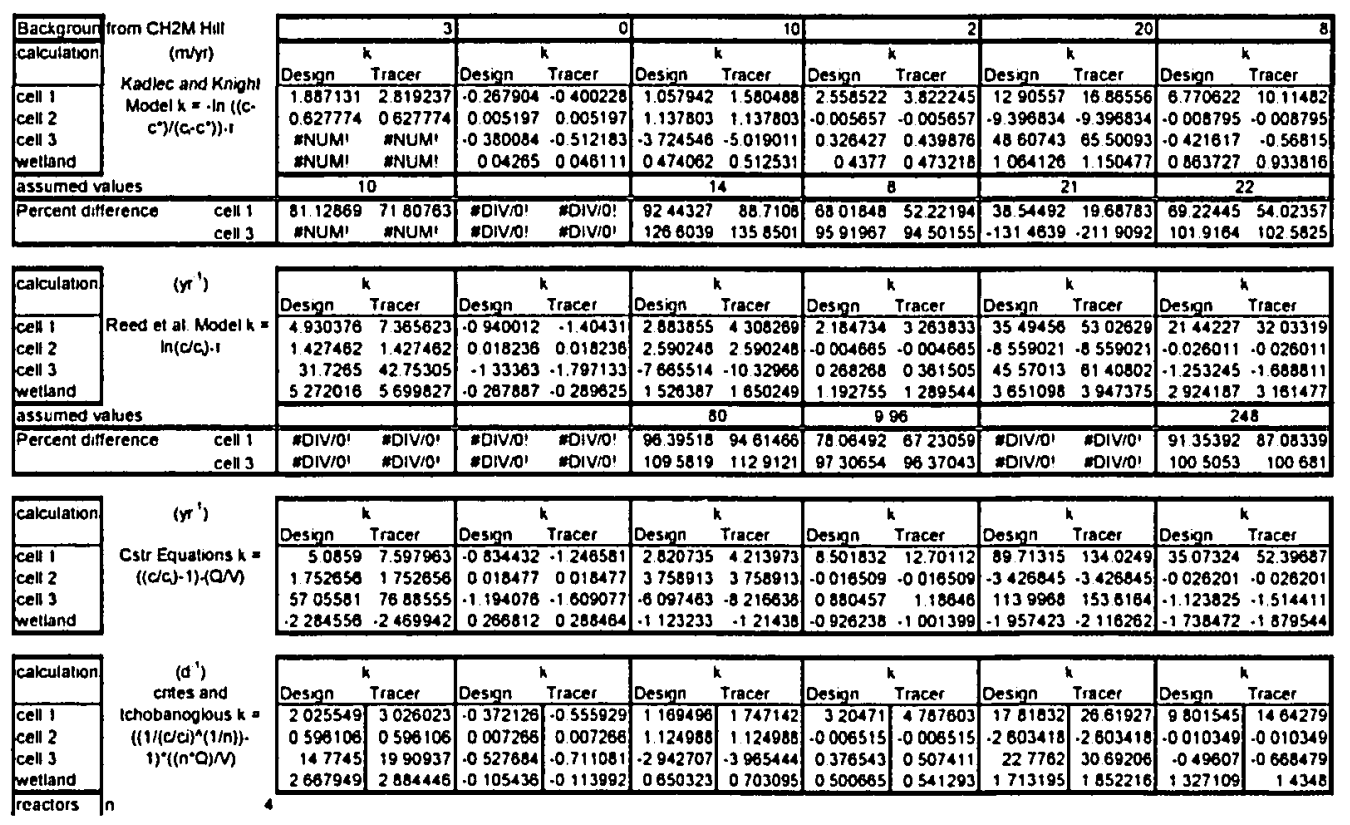

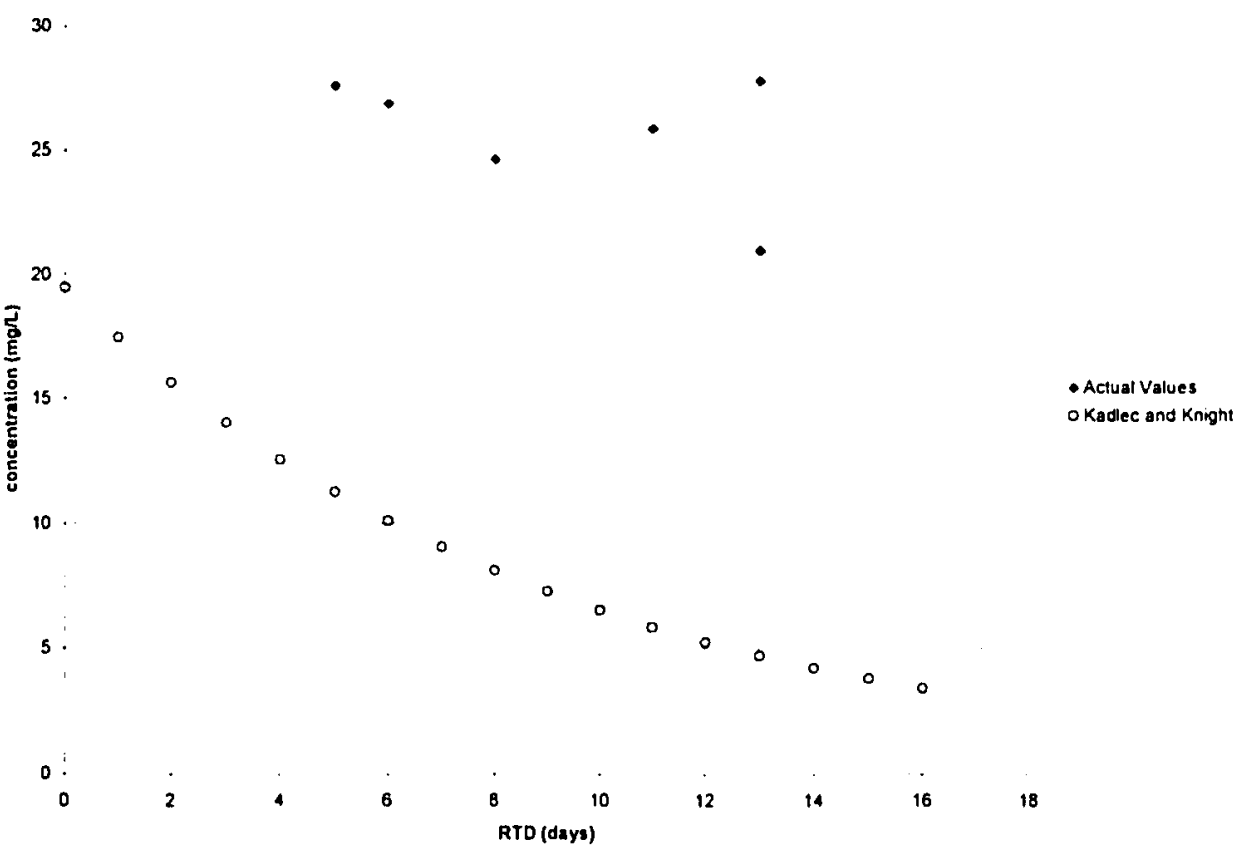

Figure D-1 TP Concentrations and Model Predictions in FWS \#1 (2003) 


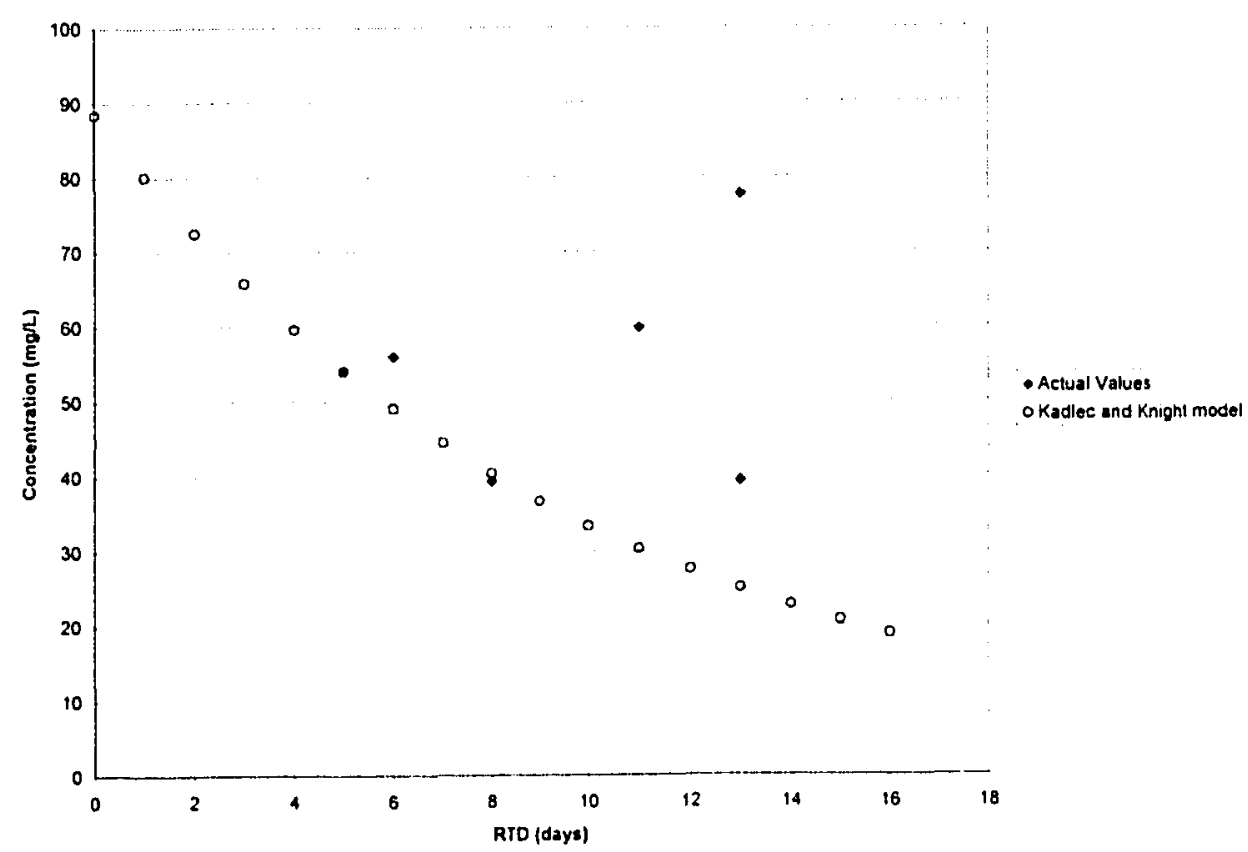

Figure D-2 TKN Concentrations and Model Predictions in FWS \#1 (2003)

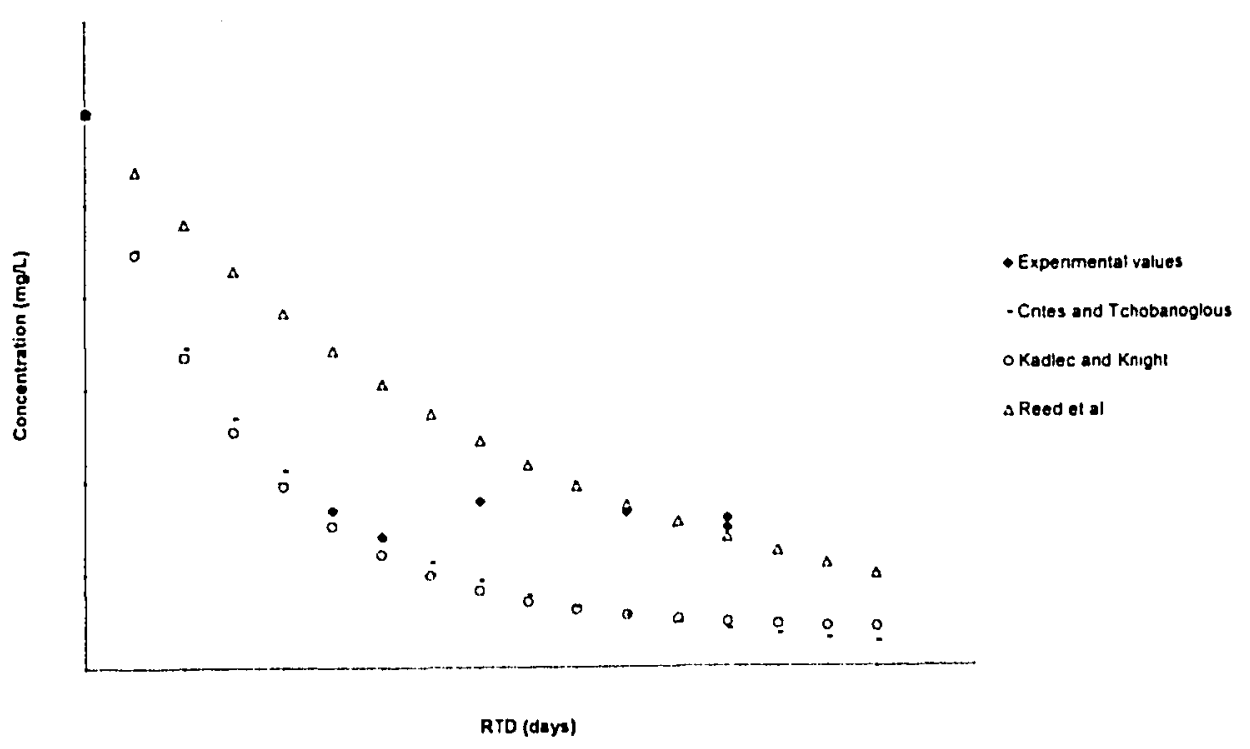

Figure D-3 BOD Concentrations and Model Predictions in FWS \#I (2003) 


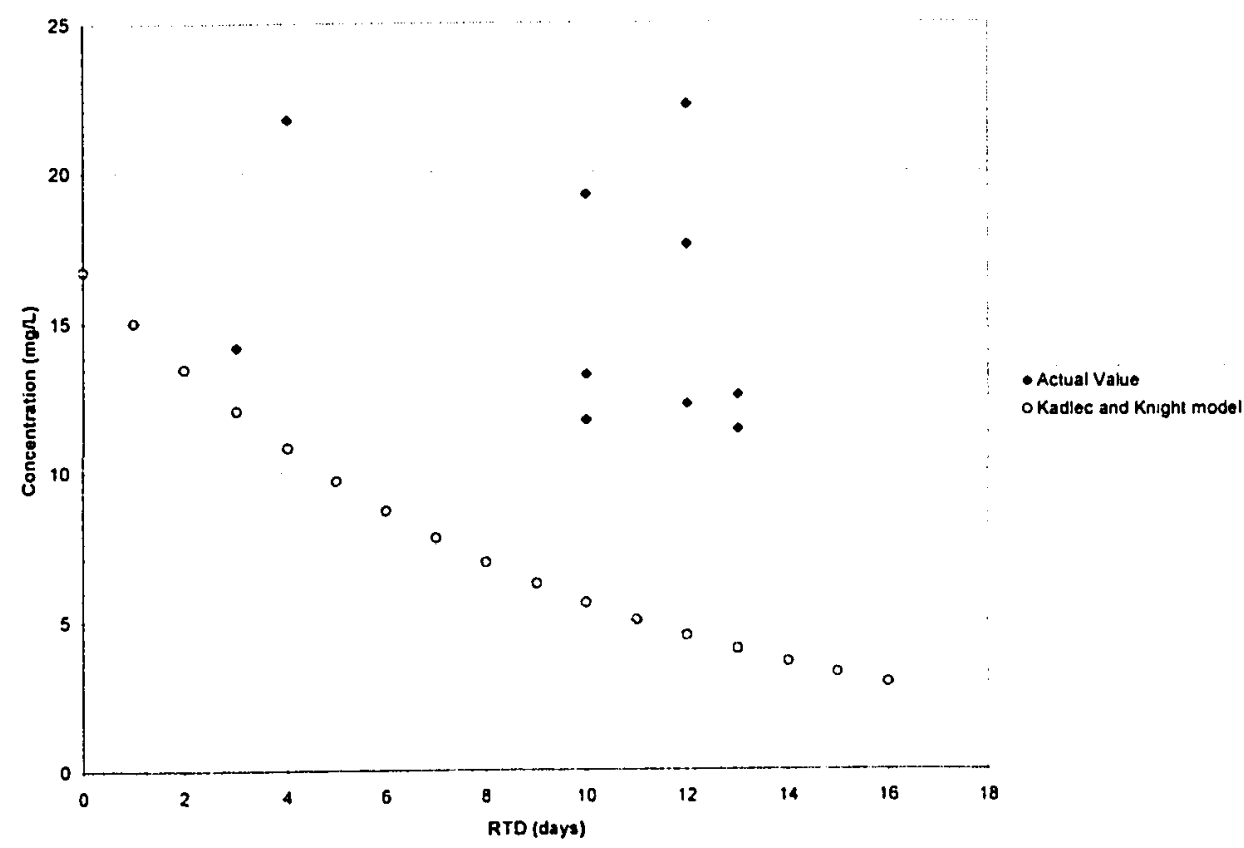

Figure D -t TP Concentrations and Model Predictions in FWS \#1 (2004)

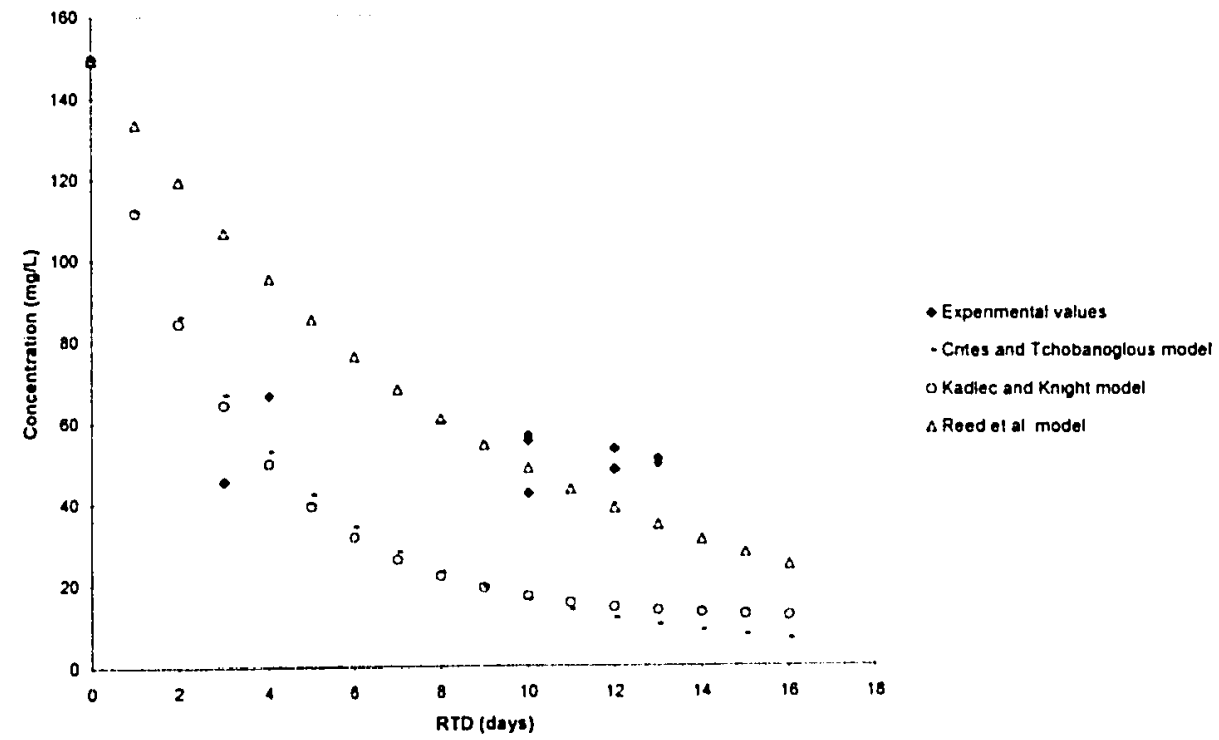

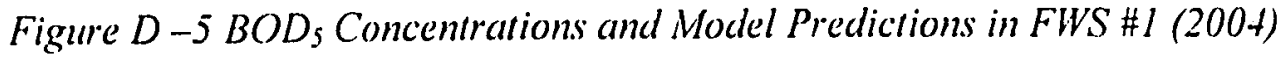




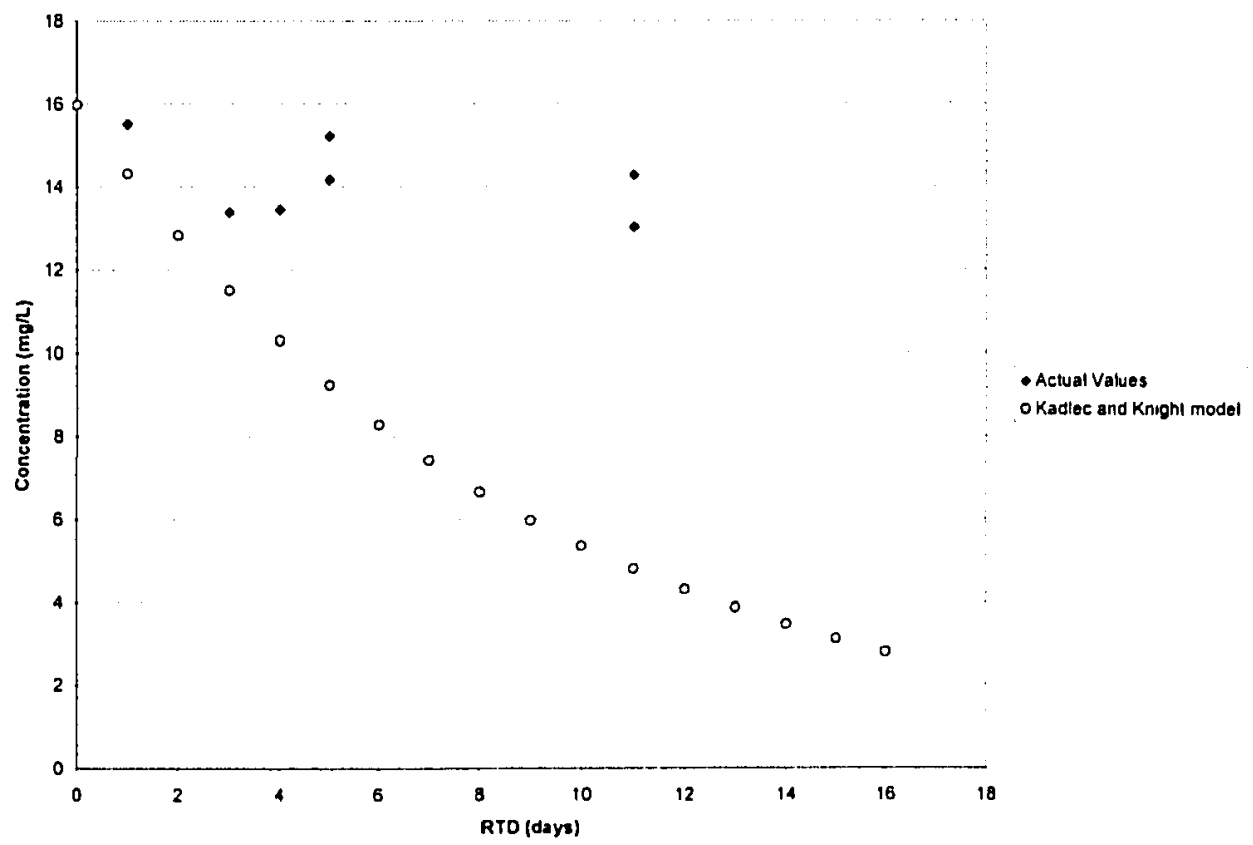

Figure D -6 TP Concentrations and Model Predictions in FWS \#2 (2003)

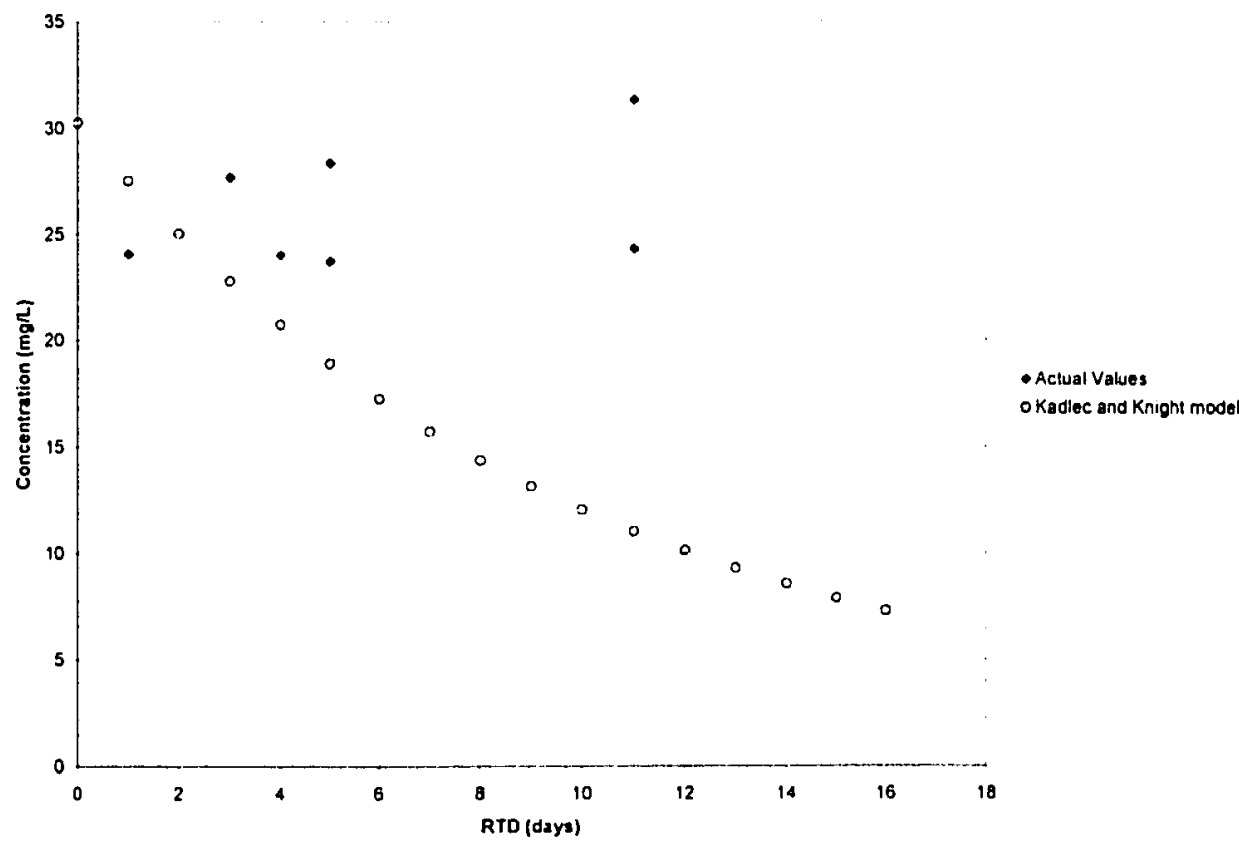

Figure D-7 TKN Concentrations and Model Predictions in FWS \#2 (2003) 


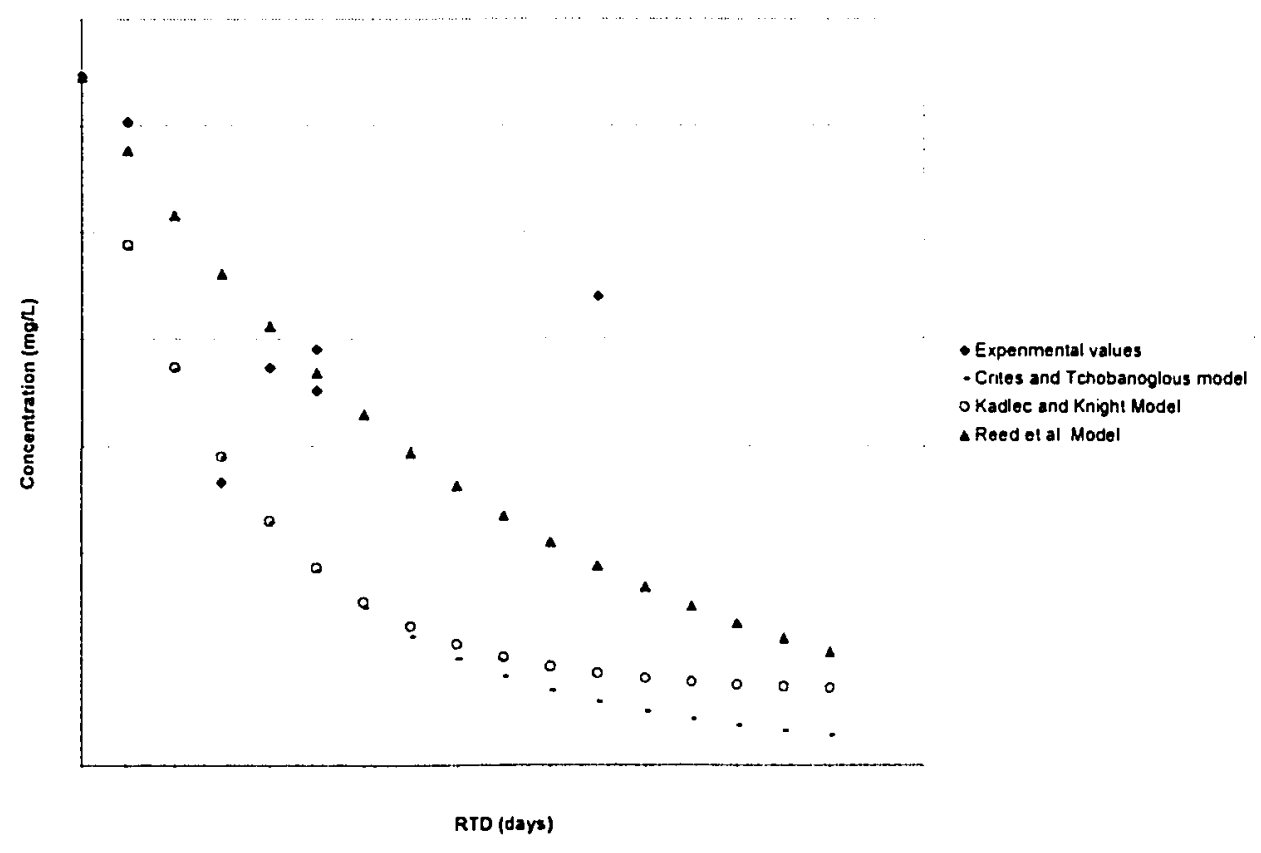

Figure $\mathrm{D}-8 \mathrm{BOD}_{5}$ Concentrations and Model Predictions in FWS \#2 (2003)

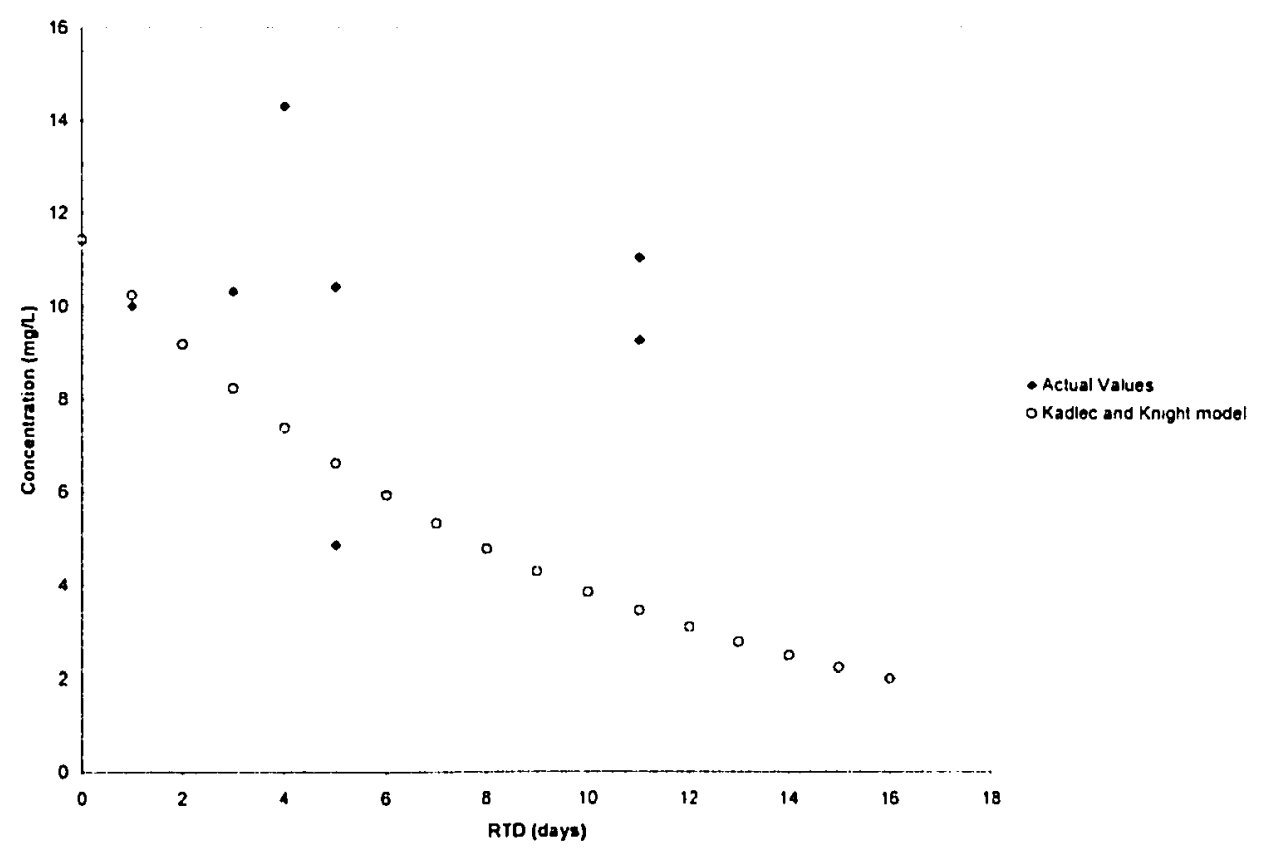

Figure D -9 TP Concentrations and Model Predictions in FWS \#2 (2004) 


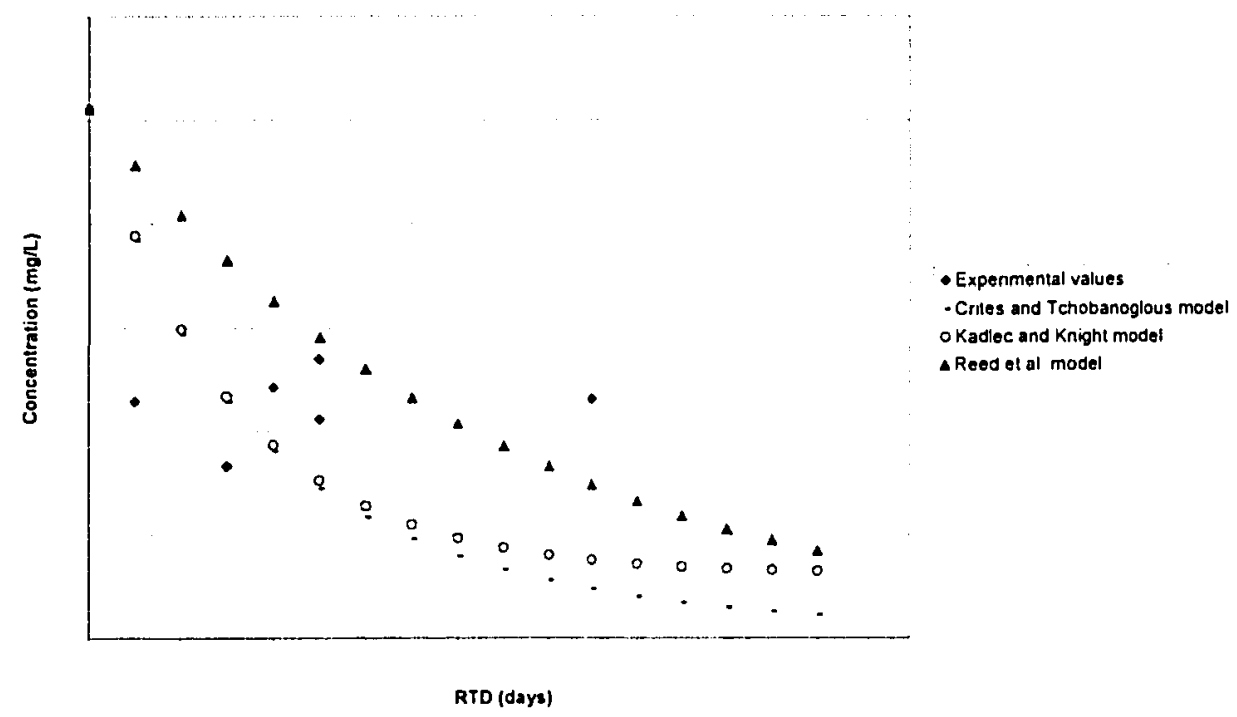

Figure D-10 BOD 5 Concentrations and Model Predictions in FWS \#2 (2004)

Ammonla Concentrations in Cell 3 (2004)

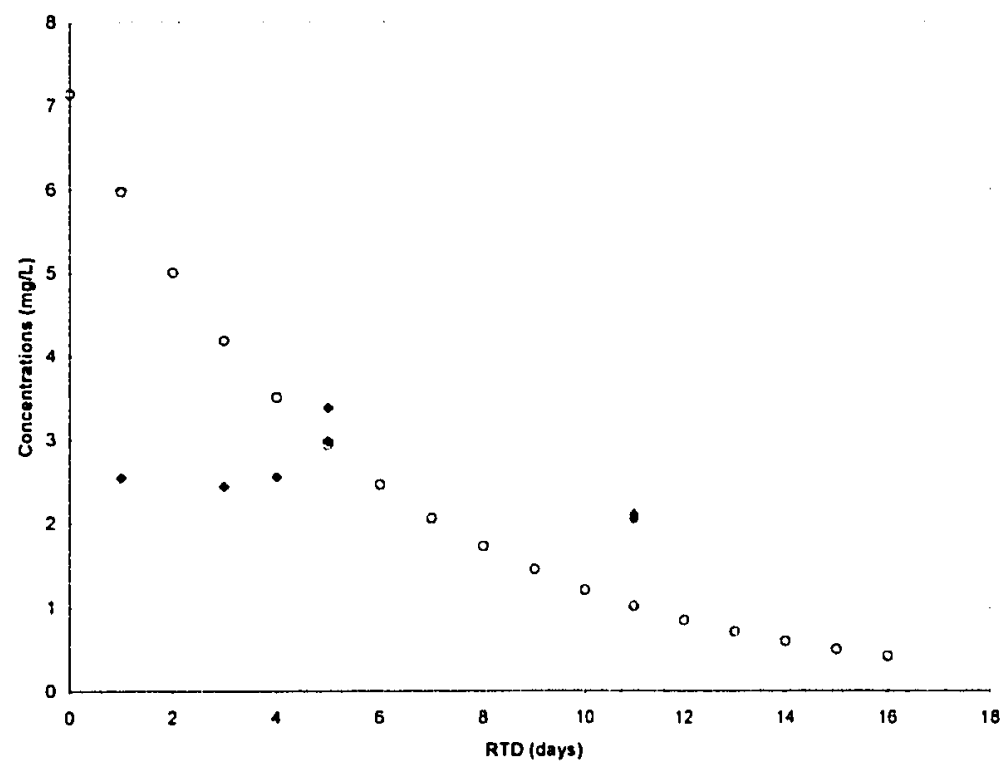

- Actual values o Kadlec and Knight Model

Figure D-11 Ammonia Concentrations and Model Predictions in FWS \#2 (2004) 